\title{
Surface and Subsurface Soils at the Pond B Dam: July 1998
}

by

N. V. Halverson

Westinghouse Savannah River Company

Savannah River Site

Aiken, South Carolina 29808

D. L. Dunn

R. J. Roseberry

W. M. Fulmer

E. A. Nelson

W. G. Cartion

F. S. Moore

L. A. Geary

DOE Contract No. DE-AC09-96SR18500

This paper was prepared in connection with work done under the above contract number with the U.S.

Department of Energy. By acceptance of this paper, the publisher and/or recipient acknowledges the U.S.

Government's right to retain a nonexclusive, royalty-free license in and to any copyright covering this paper, along with the right to reproduce and to authorize others to reproduce all or part of the copyrighted paper. 


\section{DISCLAIMER}

This report was prepared as an account of work sponsored by an agency of the United States Government. Neither the United States Government nor any agency thereof, nor any of their employees, makes any warranty, express or implied, or assumes any legal liability or responsibility for the accuracy, completeness, or usefulness of any information, apparatus, product or process disclosed, or represents that its use would not infringe privately owned rights. Reference herein to any specific commercial product, process or service by trade name, trademark, manufacturer, or otherwise does not necessarily constitute or imply its endorsement, recommendation, or favoring by the United States Government or any agency thereof. The views and opinions of authors expressed herein do not necessarily state or reflect those of the United States Government or any agency thereof.

This report has been reproduced directly from the best available copy.

Available for sale to the public, in paper, from: U.S. Department of Commerce, National Technical Information Service, 5285 Port Royal Road, Springfield, VA 22161

phone: (800) 553-6847

fax: (703) 605-6900

email: orders@ntis.fedworld.gov

online ordering: http://www.ntis.gov/ordering.htm

Available electronically at http://www.doe.gov/bridge

Available for a processing fee to U.S. Department of Energy and its contractors, in paper, from: U.S. Department of Energy, Office of Scientific and Technical Information, P.O. Box 62, Oak Ridge, TN 37831-0062

phone: (865)576-8401

fax: (865)576-5728

email: reports@adonis.osti.gov 


\section{DISCLAIMER}

Portions of this document may be illegible in electronic image products. Images are produced from the best available original document. 


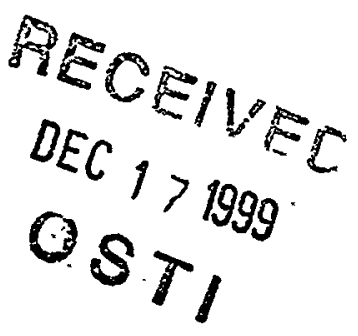

\section{Surface and Subsurface Soils at the Pond B Dam: July 1998 (U)}

D. L. Dunn, N. V. Halverson, E. A. Nelson, W. H. Carlton, F. S. Moore, L. A. Geary, R. J. Roseberry, W. M. Fulmer

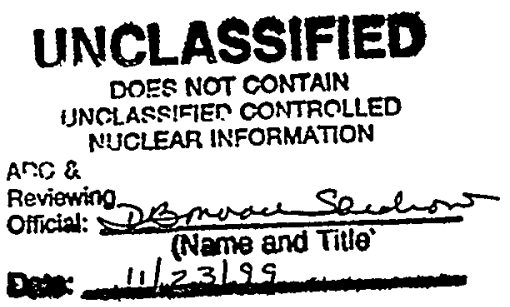




\title{
Surface and Subsurface Soils at the Pond B Dam:
}

\author{
July 1998 (U)
}

D. L. Dunn, N. V. Halverson, E. A. Nelson, W. H. Carlton, F. S. Moore, L. A. Geary, R. J. Roseberry, W. M. Fulmer Savannah River Technology Center Westinghouse Savannah River Company

Aiken, SC 29808

\section{Executive Summary}

Pond B, 685-13G, is an inactive reactor cooling impoundment located on the R-Reactor Effluent System in the eastcentral portion of the Department of Energy's (DOE) Savannah River Site (SRS) in Aiken, South Carolina. The dam was built in 1961 and is approximately 45 feet high, impounding a 30 feet deep pond with a surface area of 257 acres and a storage capacity of 4,413 acre-feet of water. Pond $B$ received radioactively contaminated cooling water from $R$ Reactor between 1961 and 1964.

Several inspections of Pond B by Westinghouse Savannah River Company (WSRC), the Federal Energy Regulatory Commission, and DOE have identified increased seepage and saturation through the earthen dam to the downstream face of the dam. The soil within the dam is losing shearing strength, thus decreasing the slope stability and internal friction angle characteristics of the soil, which are the properties by which the embankment is held in place. Repairing the Pond $B$ dam structure will require stripping topsoil and vegetation from the face of the dam and downstream from the toe, installing a new drain system and monitoring equipment, and reinforcing the embankment with additional pervious material on the downstream face of the dam.

On July 27 through July 29, 1998, soil samples were collected by Savannah River Technology Center (SRTC) Environmental Analysis Section (EAS) personnel and subcontractor staff along the downstream face and toe of the Pond $\mathrm{B}$ dam, areas that could be disturbed later during the proposed dam repair project. Additional samples were collected from Pond B sediments for comparison. Samples were analyzed at SRS to determine whether the soil contained measurable radioactive contamination as a result of seepage through the dam. Confirmation analyses were performed on a subset of samples at an independent offsite laboratory. The radiological data provided by this soil sampling study will be used to determine safety, health and radiological control precautions necessary when soil is removed from the dam during the dam repair project.

Results of the July 1998 sampling event show no evidence of radionuclide contamination on the downslope face of the Pond B dam or migration or transport of contaminants as a result of seepage through the dam. 


\section{Table of Contents}

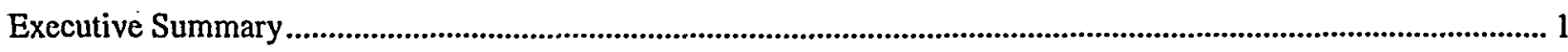

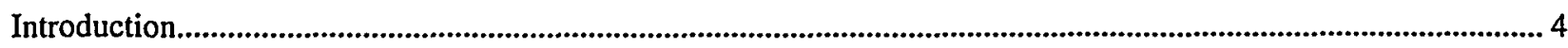

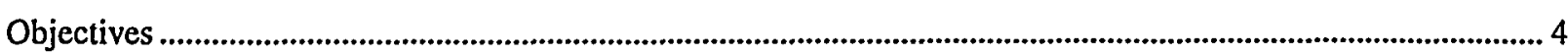

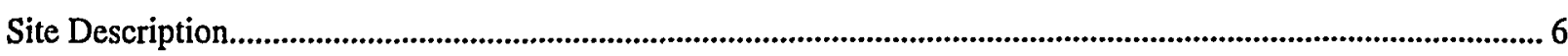

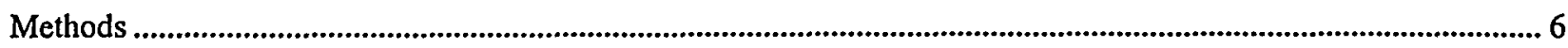

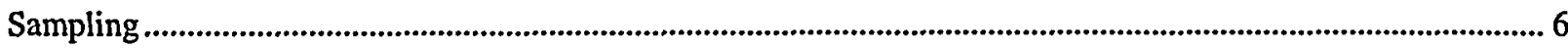

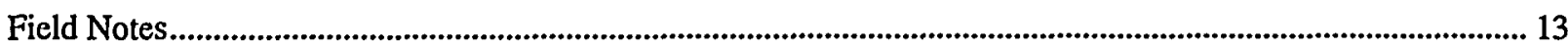

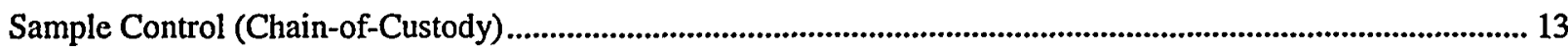

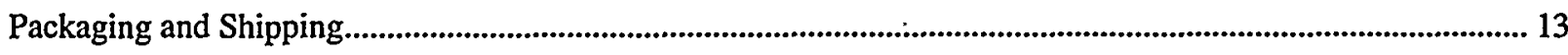

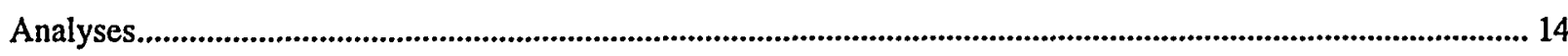

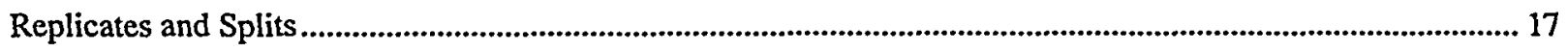

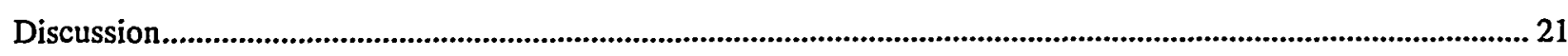

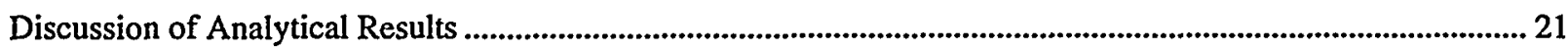

Dose Estimate for Pond B Dam Workers …................................................................................................................ 25

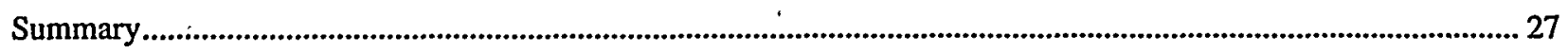

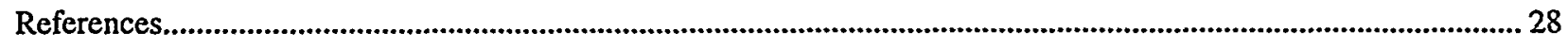

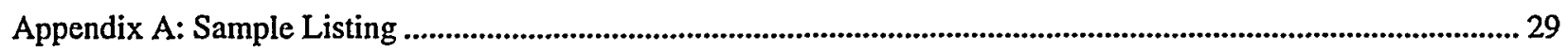

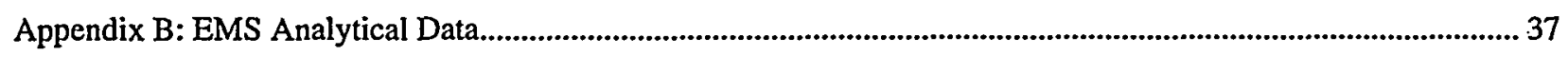

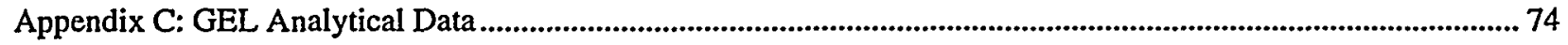




\section{List of Figures}

Figure 1. Pond B at the Savannah River Site ....................................................................................................

Figure 2. Wetland Areas near the Pond B Dam ....................................................................................................

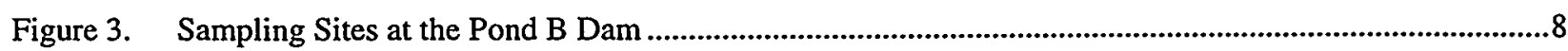

Figure 4 Photograph of Power Soil Auger Used During Sampling at the Pond B Dam .........................................10

Figure 5. Photograph Along the Face of the Pond B Dam .......................................................................................11

Figure 6. Photograph of Hand Auger Used During Sampling Downstream from the Toe of the Pond B Dam......12

Figure 7. Photograph of Sediment Sample Collection in Pond B Near the Dam....................................................14

Figure 8. Photograph of Field Gamma Survey Equipment and Setup at the Pond B Dam ...................................15

Figure 9. Spectrum for a Sediment Sample (PBS-2) and a Typical Pond B Dam Soil Sample (PBU7-1)..............16

\section{List of Tables}

Table 1. Pond B Soil and Sediment Sampling Locations.....................................................................................

Table 2. Samples Which Were Not Collected.......................................................................................................12

Table 3. Representative EMS Minimum Detectable Concentrations.........................................................................17

Table 4. Field Replicate Results, Grouped by Analyte .........................................................................................18

Table 5. Split Sample Results, Grouped by Analyte..............................................................................................20

Table 6. Radionuclides Detected at Pond B Dam Sampling Locations - July 1998 ..........................................22

Table 7. Cesium-137 Locations and Intervals Where Detected ............................................................................23

Table 8. Nationwide and SRS Background Soil Radioisotope Concentrations Compared to Pond B....................24

Table 9. Dose Estimates for Pond B Dam Workers .......................................................................................................26 


\section{Introduction}

Pond B, 685-13G, is an inactive reactor cooling impoundment built in 1961 on the Department of Energy's (DOE) Savannah River Site (SRS) in Aiken, South Carolina (Figure 1). The dam is approximately 45 feet high, impounding a 30 feet deep pond with a surface area of 257 acres and a storage capacity of 4,413 acre-feet of water. The dam is located on the R-Reactor Effluent System in the east-central portion of the SRS.

Between 1961 and 1964, Pond B received R-Reactor cooling water discharges that were contaminated with ${ }^{137} \mathrm{Cs}$, ${ }^{90} \mathrm{Sr}$ and plutonium. Though the pond has not been used since 1964, radionuclides from the contaminated cooling water remain in the water and in the surface sediments of the pond (Halverson et al. 1998).

Several inspections of the Pond B dam by Westinghouse Savannah River Company (WSRC), the Federal Energy Regulatory Commission, and DOE have identified increased seepage and saturation through the dam to the downstream face of the dam. The soil within the dam is losing shearing strength, thus decreasing the slope stability and internal friction angle characteristics of the soil, which are the properties which hold the embankment in place. The saturation problem appears to result from toe drain failure and root system penetration by trees and vegetation that were allowed to flourish over the entire dam face for a number of years.

The current proposal to fix and repair the Pond B dam structure includes installing a new drain system and monitoring equipment. Then the dam will be reinforced with additional pervious material on the downstream face of the dam.

An initial step, however, involves stripping topsoil and vegetation from the face of the dam and from at least a 50 to 100 foot area along the toe of the dam. Pond B sediments and water are known to be radioactively contaminated, and water is generally responsible for the mobility of elements in soil systems. It is important to consider the question of whether radioactive contamination could have migrated with the water through the dam to contaminate the soil on the outside surface of the dam. Soil contamination on the dam would affect the health and safety practices required for personnel repairing the dam.

A previous study of Pond B sediments indicated that maximum ${ }^{137} \mathrm{Cs}$ concentrations remained near the surface and decreased exponentially with depth, with a halving depth of $3.5 \mathrm{~cm}$. Whicker et al. (1990) determined that the adsorption coefficient, $K_{d}$, for Pond $B$ sediment/water, using shallow sediments, was $3.2 \times 10^{4}$ for ${ }^{137} \mathrm{Cs}$. This $\mathrm{K}_{d}$ value for the Pond $\mathrm{B}$ sediments is high enough that the mobility of ${ }^{137} \mathrm{Cs}$ was expected to be very low. Due to this low mobility, ${ }^{137} \mathrm{Cs}$ would not be expected to migrate very far into the dam with the seep water. Therefore contamination in the soil on the downstream face of the dam was expected to be very low.

\section{Objectives}

This sampling program was designed to determine whether soil that could later be disturbed during the proposed dam repair project contains measurable radioactive contamination as a result of seepage through the dam. Screening soil samples were collected by EAS and subcontractor staff and were analyzed at SRS. The sampling subcontractor was RCS Corporation, Engineering and Environmental Services (RCS). Confirmation analyses were, performed on a subset of the samples at an independent offsite laboratory, General Engineering Laboratories (GEL) of Charleston, SC. The radiological data provided by this soil sampling study will be used to determine safety, health and radiological control precautions necessary when soil is being removed from the dam during the dam repair project.

The objectives of this report are to:

- Describe the sampling methodology used during the July 1998 sampling event at the downstream face of the Pond $\mathrm{B}$ dam and in Pond $\mathrm{B}$,

- Present the results of the sampling event, and

- Compare, where possible, these results to related risk-based standards. 

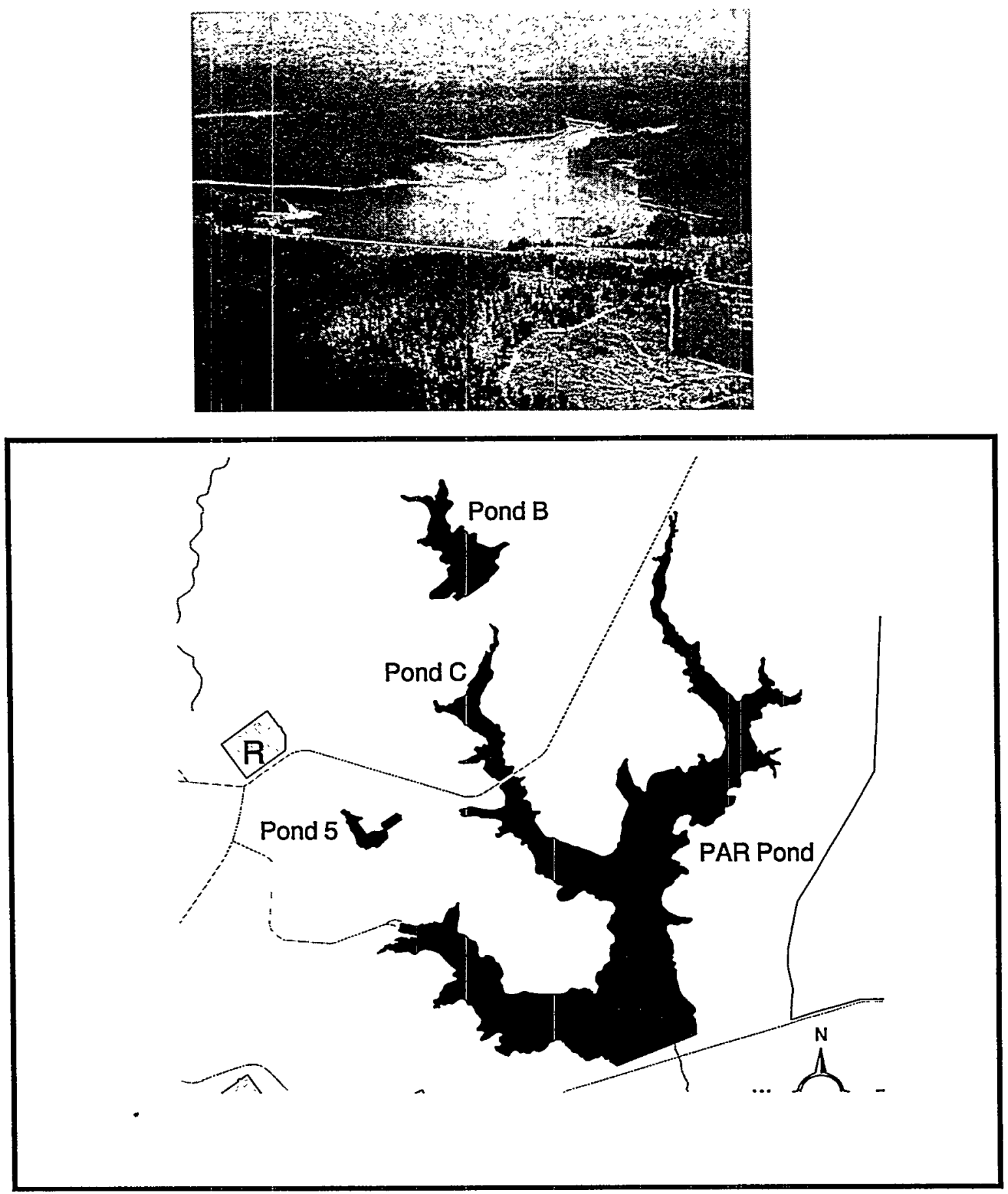

Figure 1. Pond B at the Savannah River Site 


\section{Site Description}

The proposed Pond B dam replacement project covers a variety of habitats, from the natural slopes down the hill to the floodplain itself. Beginning down the slope at the ends of the dam, much of the area is a closed canopy loblolly pine (Pinus taeda) plantation. Present in the understory are loblolly pine, red maple (Acer rubrum), sweetgum (Liquidambar styraciflua), and American holly (llex opaca). The herbaceous and vine layer is sparse and consists mainly of grape (Vitis sp.), poison oak (Rhus toxicodendron), and jessamine (Gelsemium sempervirens). Soils of this area are mapped as Blanton series.

Moving from the slope to the floodplain, most of the overstory changes to tulip tree (Liriodendron tulipifera) and red maple. A number of species are present in the understory, including tulip tree, red maple, red bay (Persea borbonia) and sweetgum. The herbaceous layer is dominated by maidencane (Panicum hemitomon), sensitive fern (Onoclea sensibilis), and juncus (Juncus sp.). Soils of this area are mapped as Fluvaquents and are listed for the SRS as hydric soils.

The wetland areas immediately below the dam (Figure 2) are believed to have been natural wetlands prior to the construction of Pond B dam, though soil saturation is likely to have increased as a result of the man-made impoundment. Roughly 3.4 acres of wetlands will be impacted by the extension of the toe of the dam 100 yards into the wetlands from the existing toe of the dam.

\section{Methods}

\section{Sampling}

The sampling described below was performed in accordance with procedures in WSRC Procedure Manual 3Q5. A total of 185 samples were scheduled for collection from 30 sampling locations. This included 86 standard samples, 86 archive samples, 3 replicates and 10 split samples. Every effort was made to collect the planned number of samples, but in a few cases, samples could not be collected as planned. Sampling locations are shown in Figure 3. Coordinates for these points are listed in Table 1.

SRTC/EAS purchased soil augering equipment to use in the hard clayey material of the Pond B dam (Figure 4). The working unit consisted of a four-cycle engine, with a centrifugal clutch, driving a flexible shaft. The flexible shaft was attached to the hand held auger drive unit. As a safety feature for the operator, a solid torque tube was used to connect the engine to the auger drive unit and to effectively transfer and absorb generated torque during operation. A dedicated tripod and winch was used to extract the augers and extensions after reaching the desired depth.

The numbered markers along the top of the dam were utilized to locate the sampling points on the dam. Sampling locations were established at an elevation just below the visible seepage line (upper tier), at points in line with the odd numbered marker (8 locations). A second tier (lower tier) of sampling locations was established along the seepage flow stream (Figure 5) at the base (toe) of the dam in line with each of the numbered markers (15 locations). Samples were also collected downstream from the toe of the dam (Figure 6), at 20-yard intervals (5 locations), with the fifth location being 100 yards from the toe of the dam. At each of the dam and downstream locations (28 locations), an attempt was made to sample each of the following intervals: surface ( $0-1$ foot), near surface ( 2 - 4 feet) and subsurface ( $4-10$ feet). A complete list of samples is provided in Appendix A.

Samples were not collected from locations and intervals where the auger would not penetrate the aggregate stone material used for drainage in the toe of the dam. In addition, samples were not collected from the subsurface interval at locations not accessible using the earth drill. Samples that were not collected are listed in Table 2. 


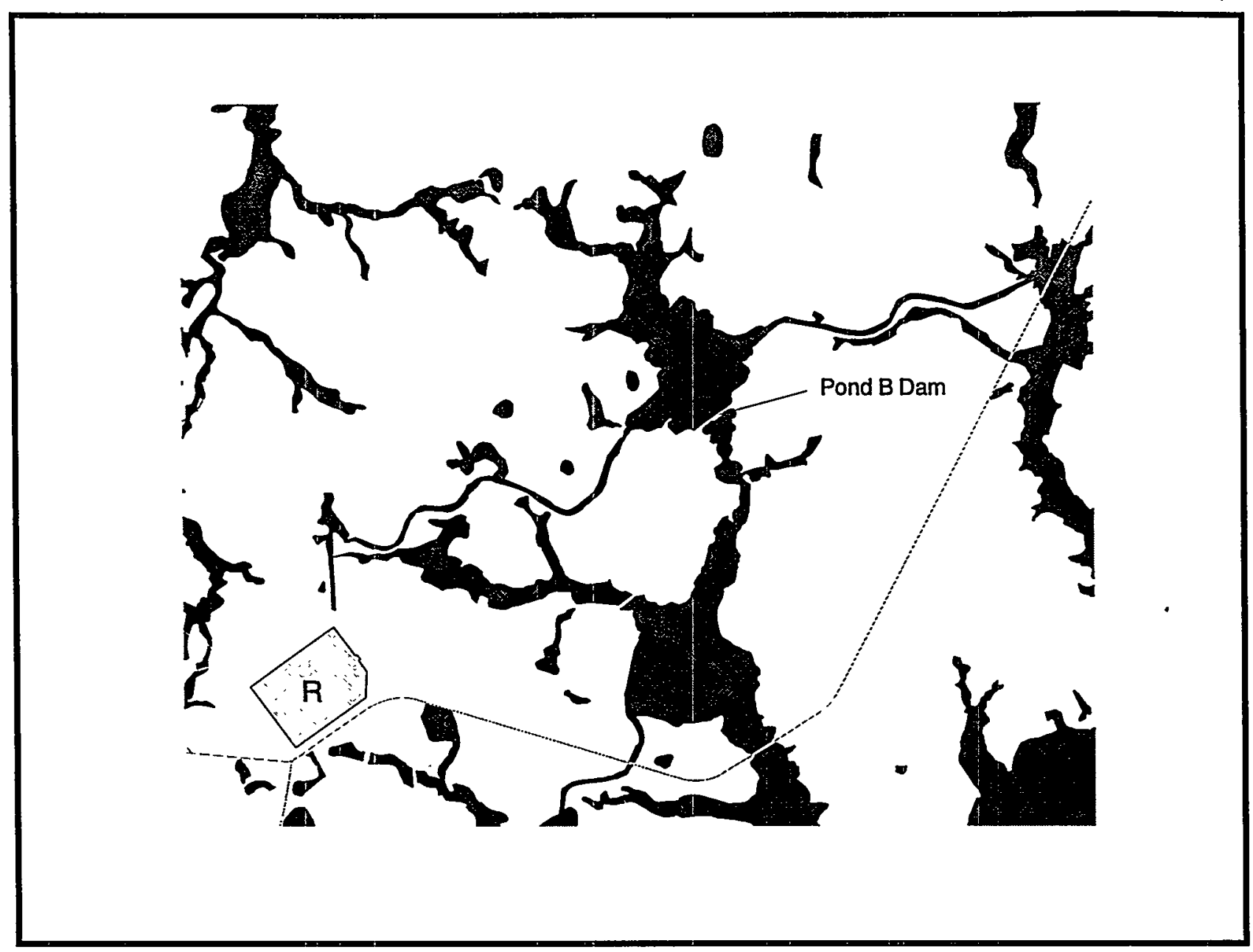

Figure 2. Wetland Areas near the Pond B Dam 


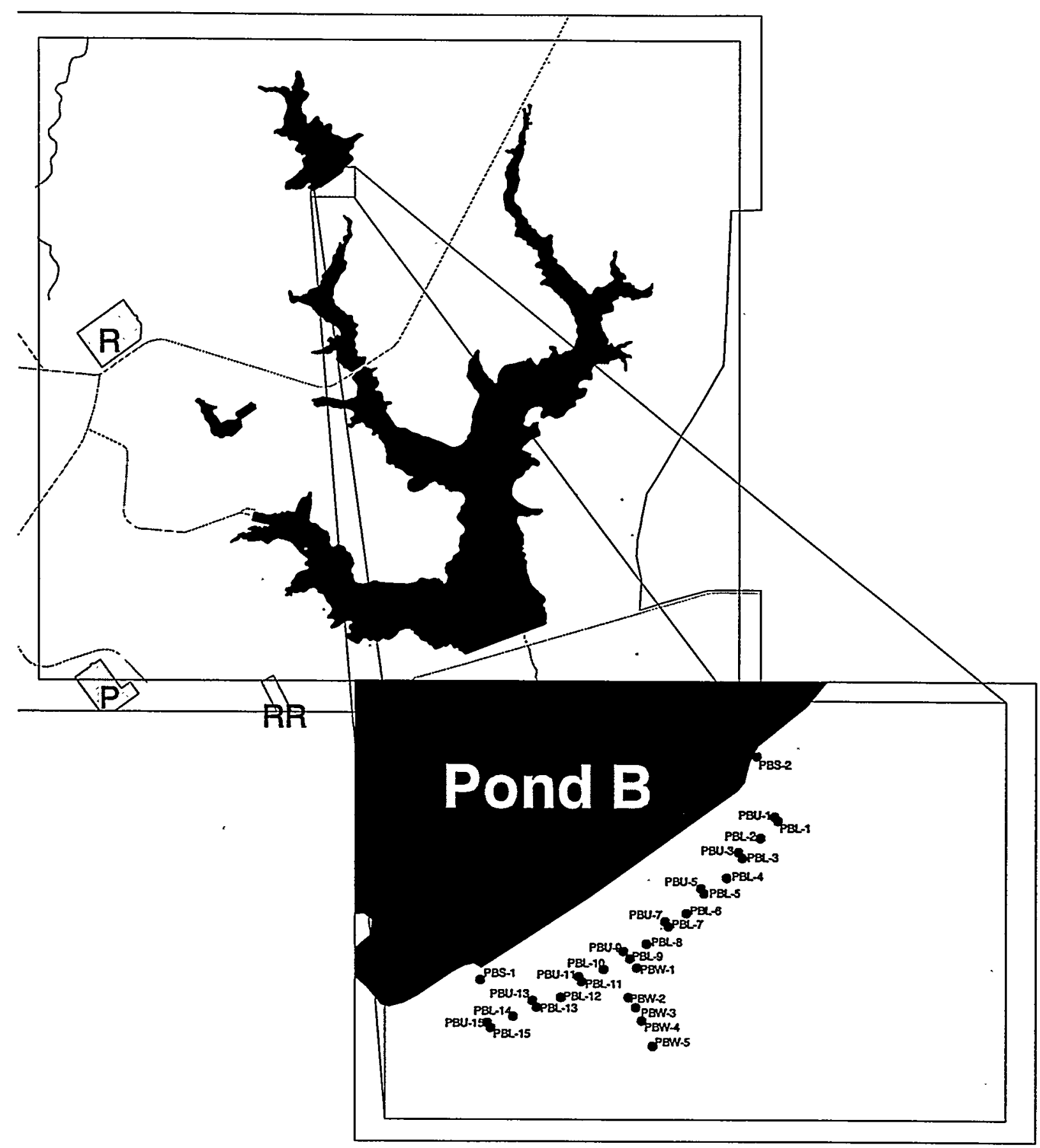

Figure 3. Sampling Sites at the Pond B Dam 
Table 1. Pond B Soil and Sediment Sampling Locations ${ }^{3}$.

\begin{tabular}{|c|c|c|c|c|c|c|}
\hline $\begin{array}{l}\text { Location } \\
\text { Number } \\
\end{array}$ & SRS-North & SRS-East & DD-North ${ }^{2}$ & DD -East ${ }^{2}$ & UTM-North & UTM-East \\
\hline PBL-1 & 56057.68 & 87893.98 & 33.2931 & 81.5442 & 3683722 & 449327 \\
\hline PBU-1 & 56080.99 & 87892.67 & 33.2932 & 81.5443 & 3683727 & 449323 \\
\hline PBL-2 & 56042.16 & 87797.27 & 33.2929 & 81.5445 & 3683701 & 449306 \\
\hline PBL-3 & 56019.80 & 87696.22 & 33.2927 & 81.5447 & 3683677 & 449285 \\
\hline PBU-3 & 56048.99 & 87695.72 & 33.2928 & 81.5447 & 3683684 & 449280 \\
\hline PBL-4 & 55994.68 & 87598.54 & 33.2925 & 81.5449 & 3683653 & 449266 \\
\hline PBL-5 & 55994.37 & 87491.58 & 33.2923 & 81.5452 & 3683634 & 449239 \\
\hline PBU-5 & 56018.42 & 87490.64 & 33.2924 & 81.5452 & 3683640 & 449235 \\
\hline PBL-6 & 55971.03 & 87389.91 & 33.2921 & 81.5454 & 3683610 & 449218 \\
\hline PBL-7 & 55970.66 & 87300.02 & 33.2919 & 81.5456 & 3683594 & 449196 \\
\hline PBU-7 & 55994.79 & 87299.03 & 33.2920 & 81.5457 & 3683600 & 449192 \\
\hline PBL-8 & 55967.15 & 87190.51 & 33.2918 & 81.5459 & 3683573 & 449170 \\
\hline PBL-9 & 55957.11 & 87102.05 & 33.2916 & 81.5461 & 3683555 & 449150 \\
\hline PBU-9 & 55995.62 & 87099.17 & 33.2917 & 81.5462 & 3683564 & 449142 \\
\hline PBL-10 & 55985.05 & 86993.13 & 33.2915 & 81.5465 & 3683542 & 449118 \\
\hline PBL-11 & 55995.29 & 86894.24 & 33.2913 & 81.5467 & 3683527 & 449092 \\
\hline PBU-11 & 56018.95 & 86895.50 & 33.2914 & 81.5468 & 3683533 & 449088 \\
\hline PBL-12 & 55993.74 & 86790.26 & 33.2912 & 81.5470 & 3683508 & 449067 \\
\hline PBL-13 & 56018.48 & 86691.27 & 33.2911 & 81.5473 & 3683496 & 449038 \\
\hline PBU-13 & 56047.46 & 86692.43 & 33.2911 & 81.5474 & 3683504 & 449033 \\
\hline PBL-14 & 56043.60 & 86594.94 & 33.2910 & 81.5476 & 3683485 & 449010 \\
\hline PBL-15 & 56056.18 & 86496.29 & 33.2908 & 81.5479 & 3683471 & 448983 \\
\hline PBU-15 & 56080.95 & 86496.15 & 33.2909 & 81.5480 & 3683477 & 448979 \\
\hline PBW-1 & 55913.48 & 87100.60 & 33.2915 & 81.5460 & 3683544 & 449158 \\
\hline PBW-2 & 55836.74 & 87005.15 & 33.2912 & 81.5461 & 3683508 & 449148 \\
\hline PBW-3 & 55787.33 & 87006.03 & 33.2911 & 81.5461 & 3683496 & 449157 \\
\hline PBW-4 & 55731.41 & 86994.49 & 33.2909 & 81.5460 & 3683480 & 449164 \\
\hline PBW-5 & 55624.03 & 86969.42 & 33.2906 & 81.5458 & 3683449 & 449177 \\
\hline PBS-1 & 56233.53 & 86577.16 & 33.2914 & 81.5480 & 3683529 & 448971 \\
\hline PBS-2 & 56315.52 & 87978.94 & 33.2938 & 81.5445 & 3683800 & 449302 \\
\hline
\end{tabular}

'Location number terminology is explained in Appendix A.

${ }^{2} \mathrm{DD}=$ Decimal Degrees.

${ }^{3}$ Sampling locations were georegistered by BSRI surveyor Kenny Wilson. 


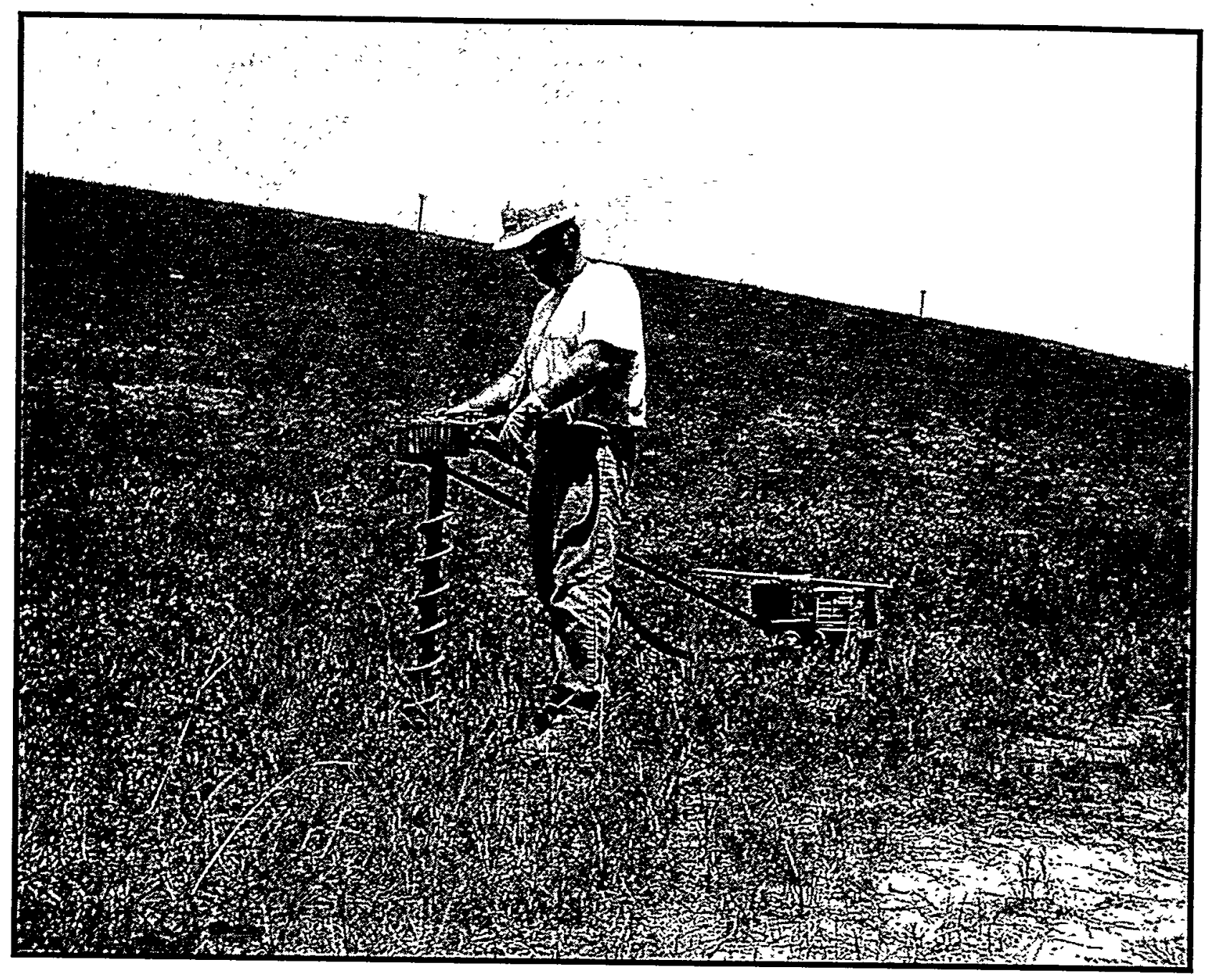

Figure 4. Photograph of Power Soil Auger Used During Sampling at the Pond B Dam 


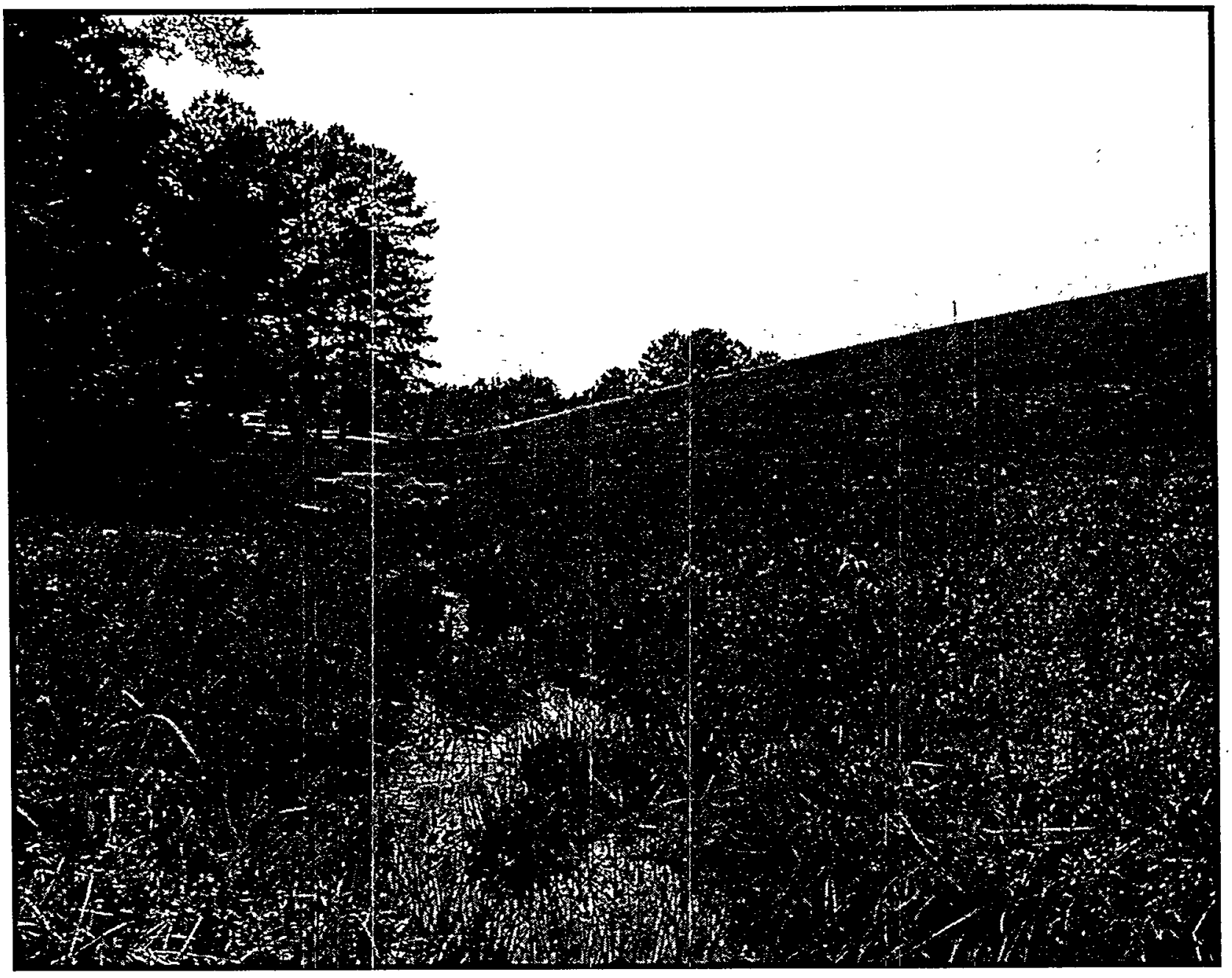

Figure 5. Photograph Along the Face of the Pond B Dam (view of seepage flow stream at the toe) 


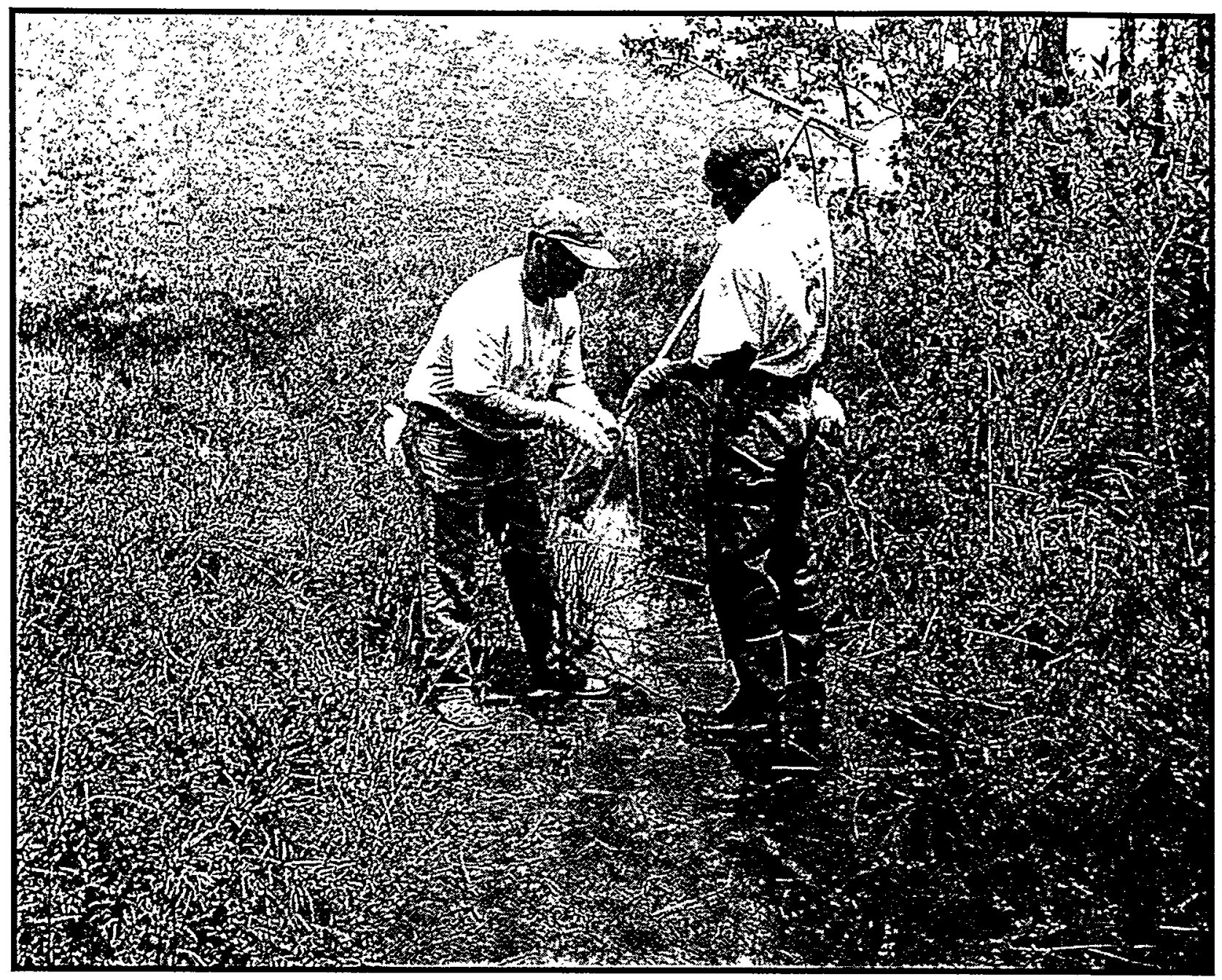

Figure 6. Photograph of Hand Auger Used During Sampling Downstream from the Toe of the Pond B Dam

Table 2. Samples Which Were Not Collected

\begin{tabular}{ll} 
Sample Number & Reason the Sample Was Not Collected \\
\hline PBL9-2 \& PBL9-2A & Auger obstructed by stones. \\
PBL9-3 \& PBL9-3A & Auger obstructed by stones. \\
PBL12-3, PBL12-3A, & Too saturated \\
PBL12-3C & \\
PBW1-3 \& PBW1-3A & Too saturated \\
PBW2-3 \& PBW2-3A & Too saturated \\
PBW3-3 \& PBW3-3A & Too saturated \\
PBW4-3, PBW4-3A, PBL4-3C & Too saturated \\
PBW5-3 \& PBW5-3A & Too saturated \\
\hline
\end{tabular}


Soil samples collected using the motor-driven auger were considered homogenized by the mixing action of the rotating auger bit. The samples collected by hand auger in the wetlands were mixed by placing the soil into a stainless steel mixing bowl and agitating the soil with a stainless steel spoon. After mixing, a field analysis for gamma radioactivity was performed. After the field screening, the soil from each sampling interval was promptly placed in polyethylene bags such that no headspace remained. The bags were then sealed and labeled. For each sampling interval, at least two bags were filled: the standard sample plus an archive sample. For sampling intervals chosen for replicate samples, three containers were filled: the standard sample, an archive sample and a replicate. For sampling intervals chosen for split samples, three containers were filled: the standard sample, archive sample, and the split sample. The subcontractor, RCS Corporation, provided the materials necessary for accomplishing these tasks, including the polyethylene bags and transport containers.

Shallow surface sediment samples were collected from 2 locations in Pond B, near the dam (Figure 3 and Figure 7) using a hand auger. EAS personnel collected these samples from the pond, then Safety and Health Operations personnel cleared the samples as nonradioactive samples requiring no special handling. SRTC completed the field screening of these sediment samples and did record measurable ${ }^{137} \mathrm{Cs}$ gamma activity. Subcontractor personnel were responsible for providing the sample bottles, applying the labels, filling out the red logbook and chain of custody, and all other aspects of preparing the samples.

\section{Field Notes}

For each sample, field notes taken during sampling included, as a minimum, the names of the personnel involved, the date and time of collection, the sample location identification number, gamma screening results and any other pertinent information relevant to the sampling procedure for each sampling location.

Samplers documented the following essential field sample information in the red logbook issued to EAS for this project by the Environmental Monitoring Section (EMS) Groundwater Monitoring Group:

- Sample ID

- Sample location

- Sample date and time

- Depth interval

- Initials of sampler

- Sample type and matrix

- Gamma screening results

- Comments on any unusual circumstances, deviations from plans, or comments relating to the quality or representativeness of the samples

- Information on the parent sample of any field replicate or split

\section{Sample Control (Chain-of-Custody)}

The sampling subcontractor, RCS Corporation, implemented chain of custody practices to insure the integrity of the sample and the accurate accounting of all documents and field/laboratory notes. Sampling Chain of Custody (COC) forms were provided by EMS for the screening samples and by the offsite contract laboratory, GEL, for the confirmation samples. The information contained on each sampling chain of custody form was not altered in any way by the subcontractor without prior consent of the EAS Technical Lead. When the analytical laboratory received samples, an internal laboratory COC began and was maintained.

\section{Packaging and Shipping}

RCS packaged all samples. Parent samples and replicates were delivered to the EMS laboratories. Split samples were packaged appropriately and delivered to personnel from General Engineering Laboratories (GEL), an independent, offsite laboratory service from Charleston, South Carolina. Archive samples were taken to an onsite storage location. 


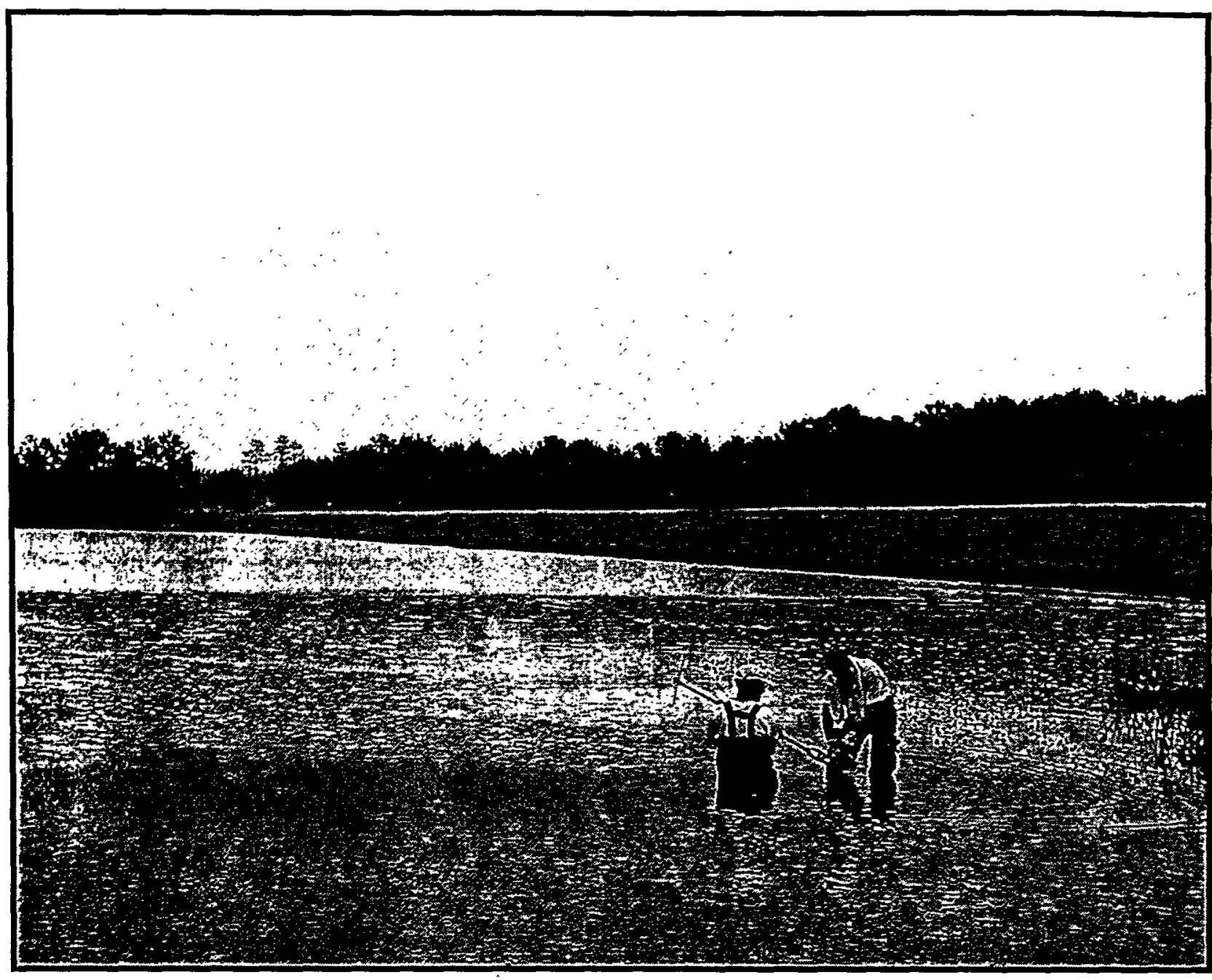

Figure 7. Photograph of Sediment Sample Collection in Pond B Near the Dam

\section{Analyses}

Samples were screened in the field for gamma radioactivity and the results were recorded the Chain of Custody forms. The apparatus used for the screening consisted of a 2 inch by 2 inch NaI detector/preamplifier and an Ortec microNomad ${ }^{\mathrm{TM}}$ portable multichannel analyzer (MCA) controlled by a laptop computer (Figure 8 ). The sodium iodide (NaI) detector was enclosed in a 0.5-inch thick steel collimator to ensure that it viewed only the soil in the sample bag. Although both the MCA and the laptop computer can be battery operated, a portable generator was used to supply 110 $\mathrm{AC}$ to the system due to the length of time required to complete each series of measurements.

The field gamma ray measurements were not intended to detect environmental radiation levels but to determine if measurable contamination levels existed in the soil samples. The NaI detector viewed a 2" diameter section of the sample bag. The counting time was 300 seconds. ${ }^{137} \mathrm{Cs}$ was the isotope of interest because it (1) is one of the most common fission products and (2) it has a long (30 years) half life to be present in measurable quantities.

Measurable ${ }^{137} \mathrm{Cs}$ contamination was found only in the two sediment samples. Figure 9 compares the spectrum found for sediment sample PBS-2 with a typical soil sample PBU7-1. The lower spectrum is PBS-2, and the dark region of interest (ROI) portion of the spectrum containing the ${ }^{137} \mathrm{Cs}$ peak. The upper spectrum is PBU7-1, and there is no corresponding peak in that portion of the spectrum. The small peak in both spectra at $609 \mathrm{KeV}$ is probably from ${ }^{214} \mathrm{Bi}$. 


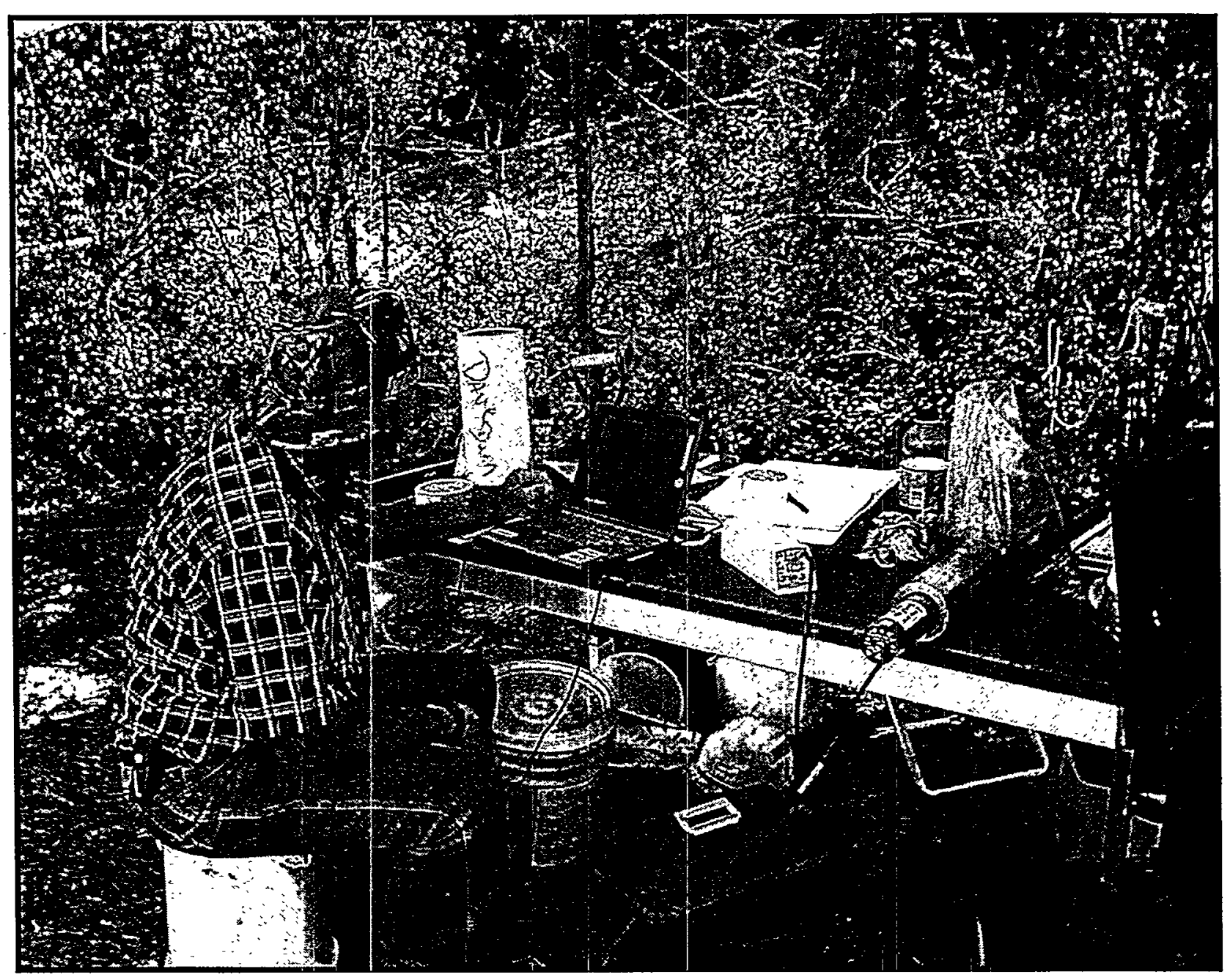

Figure 8. Photograph of Field Gamma Survey Equipment and Setup at the Pond B Dam 


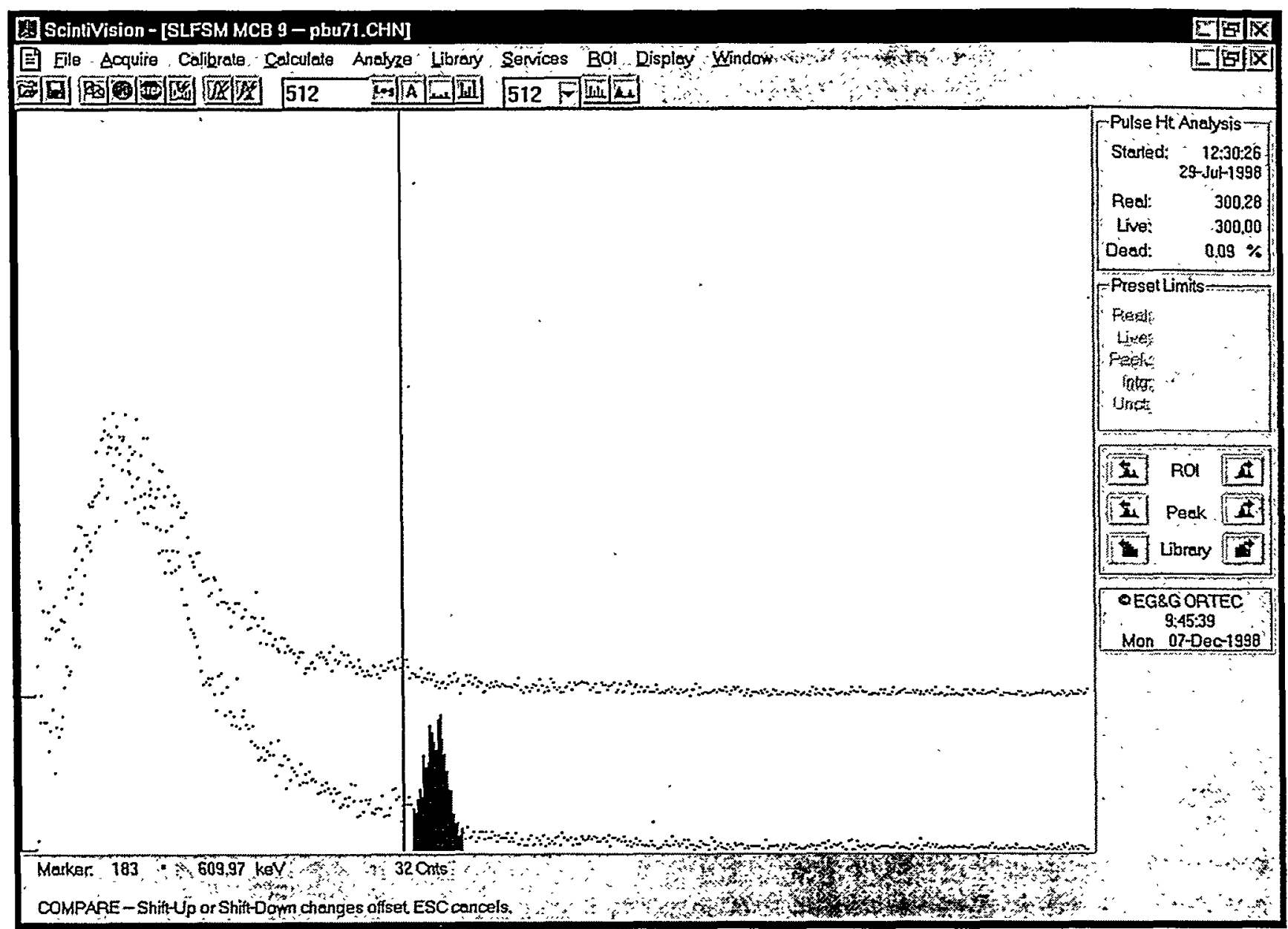

Figure 9. Spectrum for a Sediment Sample (PBS-2) and a Typical Pond B Dam Soil Sample (PBU7-1)

The ${ }^{137} \mathrm{Cs}$ content of PBS-2 assayed at $2.11 \mathrm{E}+04 \mathrm{pCi} / \mathrm{kg}$. The net count, after background subtraction, in the ROI is 679 \pm 52 , or $31.1 \mathrm{pCi} / \mathrm{kg} /$ count. A peak having $20 \%$ of the amplitude of the present peak would have been easily resolved, giving a sensitivity of the present system of $4.20 \mathrm{E}+03 \mathrm{pCi} / \mathrm{kg}$. This could be reduced with improved instrumentation.

The soil samples were prepared and analyzed using routine EMS procedures (WSRC-3Q1-4, Environmental Radiochemistry Procedures, and WSRC-3Q1-6, Environmental Counting Room Procedures). Preparation for gamma analysis required soil samples to be dried (approximately 24 hours at $105^{\circ} \mathrm{C}$ ), weighed, sifted through a \# 30 mesh $(0.6 \mathrm{~mm})$ sieve to remove large rocks and vegetation, blended for one hour, and pulverized. Approximately $500 \mathrm{ml}$ of the pulverized sample was placed into a tared $500 \mathrm{ml}$ polyethylene bottle and weighed. The bottles were filled to the $500 \mathrm{ml}$ level, which corresponded to the EMS calibration geometry. These preparations were then sent to the counting room for analysis on the Canberra Genie-VMS ${ }^{\top M}$ gamma spectrometry system

Samples were placed in proximity to a high purity germanium detector (greater than $35 \%$ efficiency) and counted for 5000 seconds. The same detector was used for all samples. One out of ten samples was recounted ( 5000 seconds) for quality assurance purposes. If a sample received a recount to confirm or rule out the presence of a radionuclide(s), the sample was counted for 10,000 seconds.

Prior to alpha/beta activity determination, samples were dried for approximately 4 hours at $105{ }^{\circ} \mathrm{C}$ then a 0.5 -gram aliquot was digested with acid. For quality control purposes, each group of approximately 8 samples contained one reagent blank, one reagent spike containing both an alpha- and beta-emitting isotope, and a matrix spike containing the 
same isotopes and one sample prepared in replicate. Each preparation was quantitatively transferred to a planchet and sent to the counting room for analysis on an Ortec Countmaster ${ }^{\top M}$ low background gas flow proportional counter. Instrument background and efficiencies were checked daily. The analyst ensured and documented that the instrument was operating within its tolerance limits on the previous and succeeding daily checks. Each sample was counted for 20 minutes.

After review by EMS counting room professional staff, the data were transferred to the information management system and then validated and verified by the EMS Data Manager. Before release, the EMS Quality Control Coordinator approved the data.

Typical minimum detectable concentrations (MDCs) are given below in Table 3. The MDCs for a specific sample may be different because of variations in the sample preparation, size, and content, and because of variations in the chemical recoveries, counting efficiencies, reagent blanks, decay time, counting time and instrument backgrounds.

Table 3. Representative EMS Minimum Detectable Concentrations

\begin{tabular}{lr} 
Nuclide & MDC $(\mathbf{p C i} / \mathbf{k g})$ \\
\hline Gross Alpha & $2.07 \mathrm{E}+03$ \\
Gross Beta & $2.88 \mathrm{E}+03$ \\
Actinium-228 & $2.077 \mathrm{E}+03$ \\
Cobalt-60 & $6.198 \mathrm{E}+01$ \\
Cesium-137 & $7.916 \mathrm{E}+01$ \\
Bismuth-212 & $5.136 \mathrm{E}+02$ \\
Bismuth-214 & $1.264 \mathrm{E}+02$ \\
Potassium-40 & $4.738 \mathrm{E}+02$ \\
Lead-212 & $1.469 \mathrm{E}+02$ \\
Lead-214 & $1.307 \mathrm{E}+02$ \\
Thallium-208 & $6.239 \mathrm{E}+01$ \\
\hline
\end{tabular}

\section{Replicates and Splits}

Field replicates are two separate aliquots of the same field sample which have been independently processed and analyzed for the same parameters by a single laboratory to determine that laboratory's precision in its sample processing and analysis systems. Three field replicates (PBS1-1, PBL11-1, and PBU5-3) were ordered for this project and delivered to EMS, the screening laboratory. A comparison of analyte results for the replicates is shown in Table 4.

Splits are two separate aliquots of the same field sample, which have been processed and analyzed for the same parameters by two independent laboratories. For this project, nine samples were split and sent to both EMS and GEL. Results for ${ }^{137} \mathrm{Cs}$ are shown in Table 5.

Results from both split samples and replicate samples can be compared as relative percent difference (RPD). RPD is calculated as the difference between two samples divided by the average result of the two samples, multiplied by one hundred to convert the number to a percentage. 
Table 4. Field Replicate Results, Grouped by Analyte

\begin{tabular}{|c|c|c|c|c|c|c|c|}
\hline $\begin{array}{l}\text { Sample } \\
\text { ID }\end{array}$ & $\begin{array}{c}\text { EMCAP } \\
\text { Root }\end{array}$ & Date & Analyte & Qualifier $^{1}$ & $\begin{array}{l}\text { Activity } \\
\text { (pCi/kg) }\end{array}$ & $\begin{array}{l}\text { 1 Sigma } \\
(\mathrm{pCi} / \mathrm{kg})\end{array}$ & $\begin{array}{l}\text { Relative \% } \\
\text { Difference }\end{array}$ \\
\hline PBS1-1B & 98808501 & 29-Jul & Cs-137 & & $1.39 \mathrm{E}+04$ & $4.42 \mathrm{E}+02$ & $17 \%$ \\
\hline PBS1-1 & 98808500 & 29-Jul & Cs-137 & & $1.65 \mathrm{E}+04$ & $5.24 \mathrm{E}+02$ & \\
\hline PBL11-1B & 98809799 & 27-Jul & Cs-137 & & $9.00 \mathrm{E}+01$ & $2.31 E+01$ & $7 \%$ \\
\hline PBL11-1 & 98809796 & 27-Jul & Cs-137 & & $9.65 \mathrm{E}+01$ & $1.84 \mathrm{E}+01$ & \\
\hline PBU5-3B & 98809730 & 28-Jul & Cs-137 & $\mathrm{U}$ & $2.22 E+01$ & $1.50 \mathrm{E}+01$ & NA \\
\hline PBU5-3 & 98809725 & 28-Jul & Cs-137 & $U$ & $-8.70 E+00$ & $1.47 \mathrm{E}+01$ & \\
\hline PBS1-1B & 98808501 & 29-Jul & Gross B & & $1.31 E+04$ & $1.51 E+03$ & $1 \%$ \\
\hline PBS1-1 & 98808500 & 29-Jul & Gross B & & $1.32 E+04$ & $1.50 \mathrm{E}+03$ & \\
\hline PBL11-1B & 98809799 & 27-Jul & Gross B & $\mathrm{U}$ & $-1.16 \mathrm{E}+03$ & $8.39 E+02$ & NA \\
\hline PBL11-1 & 98809796 & 27-Jul & Gross B & $\mathrm{U}$ & 4.27E+01 & $9.09 \mathrm{E}+02$ & \\
\hline PBU5-3B & 98809730 & 28-Jul & Gross B & U & $1.92 E+03$ & $9.86 \mathrm{E}+02$ & NA \\
\hline PBU5-3 & 98809725 & 28-Jul & Gross B & U & $1.20 \mathrm{E}+03$ & $9.27 \mathrm{E}+02$ & . \\
\hline PBS1-1B & 98808501 & 29-Jul & Gross A & & $2.78 E+03$ & $8.99 E+02$ & $20 \%$ \\
\hline PBS1-1 & 98808500 & 29-Jul & Gross A & & $3.41 E+03$ & $9.53 E+02$ & \\
\hline PBL11-1B & 98809799 & 27-Jul & Gross A & & $2.44 \mathrm{E}+03$ & $8.20 \mathrm{E}+02$ & NA \\
\hline PBL11-1 & 98809796 & 27-Jul & Gross A & $\mathrm{U}$ & $9.41 E+02$ & $5.80 \mathrm{E}+02$ & \\
\hline PBU5-3B & 98809730 & 28-Jul & Gross A & $\mathrm{U}$, & $1.38 E+03$ & $6.85 E+02$ & NA \\
\hline PBU5-3 & 98809725 & 28-Jul & Gross A & $U$ & $9.57 E+02$ & $5.99 E+02$ & \\
\hline PBL11-1B • & 98809799 & 27-Jul & Tl-208 & & $2.51 E+02$ & $3.57 \mathrm{E}+01$ & $13 \%$ \\
\hline PBL11-1 & 98809796 & 27-Jul & $\mathrm{Tl}-208$ & & $2.86 \mathrm{E}+02$ & $3.34 \mathrm{E}+01$ & \\
\hline PBS1-1B & 98808501 & 29-Jul & Tl-208 & & $4.24 E+02$ & $3.11 \mathrm{E}+01$ & $0 \%$ \\
\hline PBS1-1 & 98808500 & 29-Jul & Tl-208 & & $4.22 E+02$ & $3.00 \mathrm{E}+01$ & \\
\hline PBU5-3B & 98809730 & 28-Jul & Tl-208 & & $3.43 E+02$ & $3.84 \mathrm{E}+01$ & $2 \%$ \\
\hline PBU5-3 & 98809725 & 28-Jul & $\mathrm{Tl}-208$ & & $3.51 E+02$ & $3.42 E+01$ & \\
\hline PBL11-1B & 98809799 & 27-Jul & $\mathrm{Bi}-212$ & & $6.14 E+02$ & $1.74 \mathrm{E}+02$ & $14 \%$ \\
\hline PBL1 1-1 & 98809796 & 27-Jul & $\mathrm{Bi}-212$ & & $7.08 \mathrm{E}+02$ & $1.51 \mathrm{E}+02$ & \\
\hline PBS1-1B & 98808501 & 29-Jul & $B i-212$ & & $8.08 E+02$ & $1.33 \mathrm{E}+02$ & $10 \%$ \\
\hline PBS1-1 & 98808500 & 29-Jul & $\mathrm{Bi}-212$ & & $7.30 \mathrm{E}+02$ & $9.70 \mathrm{E}+01$ & \\
\hline PBU5-3B & 98809730 & 28-Jul & $\mathrm{Bi}-212$ & & $1.06 E+03$ & $2.07 \mathrm{E}+02$ & $21 \%$ \\
\hline PBU5-3 & 98809725 & 28-Jul & $\mathrm{Bi}-212$ & & $8.57 E+02$ & $1.74 \mathrm{E}+02$ & \\
\hline
\end{tabular}

$\mathrm{I}=$ Analyzed for but not detected.

NA $=$ Not Applicable. 
Table 4. Field Replicate Results, Grouped by Analyte (continued)

\begin{tabular}{|c|c|c|c|c|c|c|c|}
\hline $\begin{array}{l}\text { Sample } \\
\text { WD }\end{array}$ & $\begin{array}{c}\text { EMCAP } \\
\text { Root }\end{array}$ & Date & Analyte & Qualifier $^{1}$ & $\begin{array}{l}\text { Activity } \\
\text { (pCi/kg) }\end{array}$ & $\begin{array}{l}1 \text { Sigma } \\
\text { (pCi/kg) }\end{array}$ & $\begin{array}{c}\text { Relative \% } \\
\text { Difference (RPD) }\end{array}$ \\
\hline PBL11-1B & 98809799 & 27-Jul & $\mathrm{Bi}-214$ & & $6.84 \mathrm{E}+02$ & $5.77 \mathrm{E}+01$ & $5 \%$ \\
\hline PBL11-1 & 98809796 & 27-Jul & $\mathrm{Bi}-214$ & & $6.51 \mathrm{E}+02$ & $6.01 \mathrm{E}+01$ & \\
\hline PBS1-1B & 98808501 & 29-Jul & $\mathrm{Bi}-214$ & & $7.43 E+02$ & $4.27 \mathrm{E}+01$ & $6 \%$ \\
\hline PBS1-1 & 98808500 & 29-Jul & $\mathrm{Bi}-214$ & & $7.03 E+02$ & $4.20 \mathrm{E}+01$ & \\
\hline PBU5-3B & 98809730 & 28-Jul & $\mathrm{Bi}-214$ & & $7.84 \mathrm{E}+02$ & $6.18 \mathrm{E}+01$ & $10 \%$ \\
\hline PBU5-3 & 98809725 & 28-Jul & $\mathrm{Bi}-214$ & & $8.65 \mathrm{E}+02$ & $6.16 \mathrm{E}+01$ & \\
\hline PBL11-1B & 98809799 & 27-Jul & $\mathrm{Pb}-212$ & & $8.51 \mathrm{E}+02$ & $6.55 \mathrm{E}+01$ & $1 \%$ \\
\hline PBL11-1 & 98809796 & 27-Jul & $\mathrm{Pb}-212$ & & $8.57 \mathrm{E}+02$ & $6.20 \mathrm{E}+01$ & \\
\hline PBS1-1B & 98808501 & 29-Jul & $\mathrm{Pb}-212$ & & $1.22 \mathrm{E}+03$ & $5.92 \mathrm{E}+01$ & $12 \%$ \\
\hline PBS1-1 & 98808500 & 29-Jul & $\mathrm{Pb}-212$ & & $1.08 \mathrm{E}+03$ & $5.45 \mathrm{E}+01$ & \\
\hline PBU5-3B & 98809730 & 28-Jul & $\mathrm{Pb}-212$ & & $1.05 E+03$ & $7.41 \mathrm{E}+01$ & $7 \%$ \\
\hline PBU5-3 & 98809725 & 28-Jul & $\mathrm{Pb}-212$ & & $9.76 \mathrm{E}+02$ & $7.03 E+01$ & \\
\hline PBL11-1B & 98809799 & 27-Jul & $\mathrm{Pb}-214$ & & $5.81 E+02$ & $5.68 \mathrm{E}+01$ & $6 \%$ \\
\hline PBL11-1 & 98809796 & 27-Jul & $\mathrm{Pb}-214$ & & $5.49 \mathrm{E}+02$ & $5.76 E+01$ & \\
\hline PBS1-1B & 98808501 & 29-Jul & $\mathrm{Pb}-214$ & & $7.78 \mathrm{E}+02$ & $5.65 \mathrm{E}+01$ & $8 \%$ \\
\hline PBS1-1 & 98808500 & 29-Jul & $\mathrm{Pb}-214$ & & $7.16 \mathrm{E}+02$ & $5.39 \mathrm{E}+01$ & \\
\hline PBU5-3B & 98809730 & 28-Jul & $\mathrm{Pb}-214$ & & $9.41 E+02$ & $7.23 E+01$ & $9 \%$ \\
\hline PBU5-3 & 98809725 & 28-Jul & $\mathrm{Pb}-214$ & & $8.57 E+02$ & $7.27 \mathrm{E}+01$ & \\
\hline PBL11-1B & 98809799 & 27-Jul & $\mathrm{K}-40$ & & $6.05 E+02$ & $2.35 \mathrm{E}+02$ & $15 \%$ \\
\hline PBL11-1 & 98809796 & 27-Jul & $\mathrm{K}-40$ & & $5.19 E+02$ & $2.28 \mathrm{E}+02$ & \\
\hline PBS1-1B & 98808501 & 29-Jul & $\mathrm{K}-40$ & & $1.01 E+03$ & $1.54 \mathrm{E}+02$ & $35 \%$ \\
\hline PBS1-1 & 98808500 & 29-Jul & $\mathrm{K}-40$ & & $7.11 \mathrm{E}+02$ & $1.77 \mathrm{E}+02$ & \\
\hline PBU5-3B & 98809730 & 28-Jul & $\mathrm{K}-40$ & & $7.16 \mathrm{E}+02$ & $2.66 E+02$ & $41 \%$ \\
\hline PBU5-3 & 98809725 & 28-Jul & $\mathrm{K}-40$ & & $1.09 \mathrm{E}+03$ & $2.89 \mathrm{E}+02$ & \\
\hline
\end{tabular}

${ }^{1} \mathrm{U}=$ Analyzed for but not detected.

NA = Not Applicable. 
Table 5. Split Sample Results, Grouped by Analyte

\begin{tabular}{|c|c|c|c|c|c|c|c|}
\hline Laboratory & Sample ID & Parameter & $\begin{array}{l}\text { Detection Limit } \\
\quad(\mathrm{pCi} / \mathrm{kg})\end{array}$ & Qualifier $^{1}$ & $\begin{array}{l}\text { Activity } \\
\text { (pCi/kg) }\end{array}$ & $\begin{array}{l}1 \text { Sigma } \\
\text { (pCi/kg) }\end{array}$ & $\begin{array}{l}\text { Relative \% } \\
\text { Difference }\end{array}$ \\
\hline EMS & PBL3-2 & Cs-137 & $5.0 \mathrm{E}+01$ & $U$ & $5.95 E+00$ & $8.70 E+00$ & NA \\
\hline GEL & PBL3-2C & Cs-137 & $3.57 \mathrm{E}+01$ & $\mathrm{U}$ & $2.60 \mathrm{E}+01$ & $2.10 \mathrm{E}+01$ & \\
\hline EMS & PBL5-2 & Cs- 137 & $6.0 \mathrm{E}+01$ & $\mathrm{U}$ & $2.32 \mathrm{E}+01$ & $1.62 \mathrm{E}+01$ & NA \\
\hline GEL & PBL5-2C & Cs-137 & $3.41 \mathrm{E}+01$ & $\mathrm{U}$ & $1.61 \mathrm{E}+01$ & $2.75 E+01$ & \\
\hline EMS & PBL7-1 & Cs-137 & $6.0 \mathrm{E}+01$ & $\mathrm{U}$ & $4.46 \mathrm{E}+01$ & $2.16 \mathrm{E}+01$ & NA \\
\hline GEL & PBL7-1C & Cs-137 & $3.05 E+01$ & & $1.20 \mathrm{E}+02$ & $3.59 \mathrm{E}+01$ & \\
\hline EMS & PBL9-1 & Cs-137 & $5.0 \mathrm{E}+01$ & U & $2.02 E+01$ & $1.76 \mathrm{E}+01$ & NA \\
\hline GEL & PBL9-1C & Cs-137 & $3.87 \mathrm{E}+01$ & & $1.10 \mathrm{E}+02$ & $3.79 E+01$ & \\
\hline EMS & PBL11-3 & Cs-137 & $5.0 \mathrm{E}+01$ & $\mathrm{U}$ & $1.78 \mathrm{E}+01$ & $1.29 \mathrm{E}+01$ & NA \\
\hline GEL & PBL11-3C & Cs-137 & $2.67 \mathrm{E}+01$ & & $6.75 \mathrm{E}+01$ & $2.93 E+01$ & \\
\hline EMS & PBU7-1 & Cs-137 & $6.0 \mathrm{E}+01$ & & $2.84 \mathrm{E}+02$ & $4.31 E+01$ & $52 \%$ \\
\hline GEL & PBU7-1C & Cs-137 & $2.92 E+01$ & & $1.66 \mathrm{E}+02$ & $5.32 \mathrm{E}+01$ & \\
\hline EMS & PBU11-2 & Cs- 137 & $6.0 \mathrm{E}+01$ & $\mathrm{U}$ & $3.70 \mathrm{E}+00$ & $1.55 \mathrm{E}+01$ & NA \\
\hline GEL & PBU11-2C & Cs-137 & $6.43 \mathrm{E}+01$ & $\mathrm{U}$ & $3.82 \mathrm{E}+01$ & $4.43 E+01$ & \\
\hline EMS & PBW3-1 & Cs-137 & $3.0 \mathrm{E}+01$ & & $3.89 \mathrm{E}+01$ & $1.61 \mathrm{E}+01$ & $99 \%$ \\
\hline GEL & PBW3-1C & Cs- 137 & $2.09 \mathrm{E}+01$ & & $1.15 E+02$ & $3.19 \mathrm{E}+01$ & \\
\hline EMS & PBS2-1 & Cs-137 & $8.0 \mathrm{E}+01$ & & $2.11 E+04$ & $6.70 E+02$ & $8 \%$ \\
\hline GEL & PBS2-1C & Cs-137 & $3.59 \mathrm{E}+01$ & & $1.94 \mathrm{E}+04$ & $2.21 E+03$ & \\
\hline
\end{tabular}

${ }^{1} \mathrm{U}=$ Analyzed for but not detected.

NA $=$ Not Applicable.

Sample replication is the preparation and/or analysis of two or more aliquots of the same sample. They are used as a measure of the ability of the laboratory to obtain the same result on the same sample on repeated analysis. Sample replicates are the primary source of information for determination of the precision of an analysis. There are several possible interpretations of the results obtained from the analysis of replicates. The first case involves a result above the reporting level derived from the replicates. The closeness of the individual results gives a direct indication of the ability of the test to generate a reproducible result on the real sample. It is an approximation of the width of the distribution of the random error associated with the measurement technique at that level of analyte. For a measurement technique where the contaminant of interest is almost always measured in the sample, sample replicates are a very useful quality control.

The second case concerns an analyte that is not detected in the sample and the replicate. The inability of the measurement technique to detect an analyte in the sample is possible information that can be used in a verification of the lack of contamination in the sample. However, it may also be a result of a failure of the measurement technique to function properly. Proper functioning of the measurement technique must be confirmed by other means, such as matrix spikes and matrix spike duplicates. 
The third case is where the analyte is present in the sample at the detection limit or the reporting level. Sometimes the sample and the replicate results will fortuitously lie on the reportable side of the detection limit; however the more common occurrence is that the values bracket the detection limit. This gives one result as a number and the other as not detected.

Although some samples are heterogeneous and will give poor comparability for the replicates, regular occurrences of wide variation in the results of replicate analysis would be cause for concern. Such wide variation of results may suggest that the laboratory is not performing the preparation procedures in exactly the same manner for each sample. The relative percent difference (RPD) should be less than $35 \%$ for soil analysis replicates at the same laboratory. A review of RPD in Table 4 reveals that they generally meet the $<35 \%$ RPD. There were two exceptions in the analysis of ${ }^{40} \mathrm{~K}$.

The ${ }^{137} \mathrm{Cs}$ analysis results for the split samples sent to EMS and to GEL are shown in Table 5 above. The GEL detection limits are lower and GEL sample results were more frequently measured greater than the detection limit. In the three samples, PBU-7, PBW3-1 and PBS-2, where both GEL and EMS measured ${ }^{137} \mathrm{Cs}$ above detection limits the RPDs were $52 \%, 99 \%$ and $8 \%$ respectively. At PBU-7, both laboratories measured ${ }^{137} \mathrm{Cs}$ slightly above the detection limit. In sample PBS-2, the ${ }^{137} \mathrm{Cs}$ was measured well above the detection limit. With more activity and a greater count rate, each laboratory's measure of ${ }^{137} \mathrm{Cs}$ in PBS-2 is more precise than similar measurements of ${ }^{137} \mathrm{Cs}$ in the other samples. The $8 \%$ RPD between GEL and EMS in sample PBS-2 is a good inter-laboratory confirmation of statistical agreement between the sample handling and analysis techniques for both laboratories. In the other split samples the ${ }^{137} \mathrm{Cs}$ analyses are consistently at or below the detection limits for GEL and EMS and the RPD is generally "Not Applicable (NA)".

\section{Discussion}

\section{Analytical Results}

Three laboratories provided analytical services. The Analytical Development Section (ADS) from SRTC provided the field gamma screening. The Environmental Monitoring Section (EMS) of the Environment, Safety, Health and Quality Assurance Division provided laboratory radioanalytical screening results and General Engineering Laboratories (GEL) from Charleston, SC performed the confirmation radioanalytical results on the split samples.

EMS analytical results for the July 1998 sampling event at the Pond B dam are presented in Appendix B. Lab blanks and standards are not presented. Sample data are presented with the sample number, transect number, depth interval, analysis laboratory number, sample date, analyte, detection limit, result qualifier, result, and standard error. Data presented in Appendix B should be considered scoping level data.

Table 6 lists the radioisotopes detected by EMS in the samples and the average and maximum results. Cesium-137 and ${ }^{60} \mathrm{Co}$ are man-made radioisotopes. The remaining radioisotopes detected are naturally occurring. ${ }^{137} \mathrm{Cs}$ was detected in 25 samples. Gross alpha was detected in 33 samples and was highest in the dam samples. Gross alpha activity in some of the dam samples was roughly five times the activity in the sediment samples. Gross beta activity was detected in six samples: the three Pond B sediment samples and three upper tier dam samples. Gross beta measurements were highest in the Pond B sediment samples, with the highest sediment value $(18,700 \mathrm{pCi} / \mathrm{kg})$ being nearly twice the highest surface soil sample result $(10,100 \mathrm{pCi} / \mathrm{kg})$ from the dam. Thallium-208, ${ }^{212} \mathrm{~Pb},{ }^{214} \mathrm{~Pb}$, and ${ }^{214} \mathrm{Bi}$ were detected in all samples. Potassium-40, ${ }^{228} \mathrm{Ac}$ and ${ }^{212} \mathrm{Bi}$ were detected in most of the samples. Cobalt -60 and ${ }^{224} \mathrm{Ra}$ were detected in one sample each: a Pond B sediment sample and a lower tier sample, respectively.

In an aquatic system, many radionuclides reside almost entirely in the sediments. A much smaller fraction of the total radionuclide inventory might be found in the water column and biota. It is important to remember that seepage water is in intimate contact with soil surfaces at all times. As a result, contaminants in seepage water are never isolated from soil surfaces but are in intimate contact with them. If the direction of water movement is known, then the direction of element migration is generally known. Soil has significant surface area that can mediate various physical and chemical surface reactions, thereby affecting the rate of element migration. The primary physical reactions on soil surfaces that govern the migration of contaminants in water, are hydrolysis, oxidation, reduction, and adsorption. Adsorption is defined as the accumulation of an element at the surface of soil particles, resulting in a decrease in the concentration of the dissolved element in water. 
Table 6. Radionuclides Detected at Pond B Dam Sampling Locations - July 1998

\begin{tabular}{lcccccc}
\multicolumn{1}{c}{ Analyte } & $\begin{array}{c}\text { Number of } \\
\text { Sampling } \\
\dot{\text { Points }}\end{array}$ & $\begin{array}{c}\text { Number } \\
\text { of } \\
\text { Detects }\end{array}$ & $\begin{array}{c}\text { Average Results: } \\
\text { Dam \& } \\
\text { Downslope } \\
(\mathbf{p C i} / \mathbf{k g})^{\mathbf{1}}\end{array}$ & $\begin{array}{c}\text { Average Results: } \\
\text { Pond B } \\
\text { Sediments } \\
(\mathbf{p C i} / \mathbf{k g})^{2}\end{array}$ & $\begin{array}{c}\text { Maximum } \\
\text { Results: Dam \& } \\
\text { Downslope } \\
(\mathbf{p C i} / \mathbf{k g})^{3}\end{array}$ & $\begin{array}{c}\text { Maximum } \\
\text { Results for Pond } \\
\text { B Sediments } \\
(\mathbf{p C i} / \mathbf{k g})^{4}\end{array}$ \\
\hline Gross Alpha & 81 & 33 & 2,506 & 2,597 & 16,600 & 3,410 \\
Gross Beta & 81 & 6 & 1,135 & 15,000 & 10,100 & 18,700 \\
Actinium-228 & 81 & 80 & 1,152 & 1,277 & 2,760 & 1,480 \\
Bismuth-212 & 81 & 69 & 861 & 799 & 2,460 & 859 \\
Bismuth-214 & 81 & 81 & 768 & 845 & 1,740 & 1,090 \\
Cobalt-60 & 81 & 1 & 6 & 45 & 33 & 66 \\
Cesium-137 & 81 & 25 & 32 & 17,167 & 284 & 21,100 \\
Potassium-40 & 81 & 62 & 843 & 619 & 5,950 & 1,010 \\
Lead-212 & 81 & 81 & 1,056 & 1,210 & 2,620 & 1,330 \\
Lead-214 & 81 & 81 & 768 & 798 & 1,770 & 900 \\
Radium-224 & 81 & 1 & NA $^{5}$ & NA & 1,820 & NA \\
Thallium-208 & 81 & 81 & 375 & 451 & 938 & 508 \\
\hline
\end{tabular}

'Average of all results of samples from the dam and downslope. Includes instrument readings below detection limit. Pond B sediments not included.

${ }^{2}$ Average all result for Pond B sediments. Includes instrument readings below detection limit.

${ }^{3}$ Maximum results of all samples from the dam and downslope. Pond B sediments not included.

${ }^{4}$ Maximum results of all Pond $B$ sediment samples.

${ }^{5}$ Not Applicable. Only one sample had a value.

The radionuclide inventory of Pond B is known to be dominated by ${ }^{137} \mathrm{Cs}$. Various studies have shown that ${ }^{137} \mathrm{Cs}$ mobility through SRS soils is low. An assessment of the general ability of the soils on the SRS to retain cesium and other wastewater constituents was conducted by Looney et al. (1985). The results of their work indicated that cesium should be highly retained under reasonable conditions of $\mathrm{pH}$, oxidation potentials, and dissolved solids. Whicker et al (1990) found that Pond B sediments contained $99 \%$ of the ${ }^{137} \mathrm{Cs}$ inventory $\left(1.21 \times 10^{1} \mathrm{Ci}\right.$ in 1990), while the filtered water contained merely $0.66 \%$. They found that mobility of ${ }^{137} \mathrm{Cs}$ through Pond B sediments should be expected to be very low and pointed out the efficiency of the Pond B system for retaining radionuclides, effectively preventing dispersal of its radionuclide inventory and adequately shielding the surroundings from gamma radiation. Maximum ${ }^{137} \mathrm{Cs}$ concentrations occurred near the surface, then decreased exponentially, with a halving depth of $3.5 \mathrm{~cm}$. Numerical integration indicated that $95 \%$ of the total ${ }^{137} \mathrm{Cs}$ inventory occurred in the top $17 \mathrm{~cm}$ (Whicker et al. 1990).

For the samples collected in July 1998, the 25 sample locations and depth intervals where ${ }^{137} \mathrm{Cs}$ was detected are listed in Table 7. As expected, ${ }^{137} \mathrm{Cs}$ was detected in all three of the Pond B sediment samples. Although there has been no input of ${ }^{137} \mathrm{Cs}$ to Pond $\mathrm{B}$ in more than 30 years, previous studies have indicated that ${ }^{137} \mathrm{Cs}$ remains in the surface sediments, perhaps due to sorption of ${ }^{137} \mathrm{Cs}$ from the water or release from decaying vegetation (Pinder et al. 1995). Cesium-137 was also detected in fifteen of the dam samples and seven of the downstream samples. In all but four of these 25 samples, ${ }^{137} \mathrm{Cs}$ was detectable only in the top (surface) depth interval. The ${ }^{137} \mathrm{Cs}$ activities measured in the sediment samples were roughly two to three orders of magnitude higher than those measured in the dam samples. 
Table 7. Cesium-137 Activities, Locations and Intervals Where Detected

\begin{tabular}{|c|c|c|c|c|c|}
\hline Sample ID & $\begin{array}{c}\text { Depth } \\
\text { Interval }\end{array}$ & Date & $\begin{array}{c}\text { MDA } \\
(\text { pCi/kg) }\end{array}$ & $\begin{array}{l}\text { Activity } \\
\text { (pCi/kg) }\end{array}$ & $\begin{array}{l}1 \text { Sigma } \\
(\mathrm{pCi} / \mathrm{kg})\end{array}$ \\
\hline \multicolumn{6}{|l|}{ Lower Tier: } \\
\hline PBL2-1 & 1 & 28-Jul & $5.00 \mathrm{E}+01$ & $7.81 E+01$ & $2.95 E+01$ \\
\hline PBL4-1 & 1 & 28-Jul & $5.00 \mathrm{E}+01$ & $1.02 \mathrm{E}+02$ & $3.01 E+01$ \\
\hline PBL5-1 & 1 & 28-Jul & $6.00 \mathrm{E}+01$ & $7.41 \mathrm{E}+01$ & $2.77 \mathrm{E}+01$ \\
\hline PBL6-1 & 1 & 28-Jul & $4.00 \mathrm{E}+01$ & $1.45 \mathrm{E}+02$ & $2.81 E+01$ \\
\hline PBL11-1 & 1 & 27-Jul & $6.00 \mathrm{E}+01$ & $9.65 \mathrm{E}+01$ & $1.84 \mathrm{E}+01$ \\
\hline PBL11-1B & 1 & 27-Jul & $5.00 \mathrm{E}+01$ & $9.00 \mathrm{E}+01$ & $2.31 E+01$ \\
\hline PBL12-1 & 1 & 27-Jul & $7.00 \mathrm{E}+01$ & $9.73 E+01$ & $2.82 \mathrm{E}+01$ \\
\hline PBL13-1 & 1 & 27-Jul & $5.00 \mathrm{E}+01$ & $1.43 E+02$ & $2.89 \mathrm{E}+01$ \\
\hline PBL14-1 & 1 & 27-Jul & $4.00 \mathrm{E}+01$ & $1.17 E+02$ & $3.03 \mathrm{E}+01$ \\
\hline \multicolumn{6}{|l|}{ Upper Tier: } \\
\hline PBU3-1 & 1 & 28-Jul & $6.00 \mathrm{E}+01$ & $6.19 E+01$ & $2.54 \mathrm{E}+01$ \\
\hline PBU7-1 & 1 & 28-Jul & $6.00 \mathrm{E}+01$ & $2.84 \mathrm{E}+02$ & $4.31 \mathrm{E}+01$ \\
\hline PBU7-2 & 2 & 28-Jul & $6.00 \mathrm{E}+01$ & $6.27 \mathrm{E}+01$ & $2.39 \mathrm{E}+01$ \\
\hline PBU9-1 & 1 & 28-Jul & $5.00 \mathrm{E}+01$ & $1.35 E+02$ & $2.46 \mathrm{E}+01$ \\
\hline PBU11-1 & 1 & 27-Jul & $6.00 \mathrm{E}+01$ & $6.51 \mathrm{E}+01$ & $3.38 \mathrm{E}+01$ \\
\hline PBU15-1 & 1 & 27-Jul & $7.00 \mathrm{E}+01$ & $7.00 \mathrm{E}+01$ & $2.26 \mathrm{E}+01$ \\
\hline \multicolumn{6}{|l|}{ Downstream: } \\
\hline PBW1-2 & 2 & 29-Jul & $4.00 \mathrm{E}+01$ & $5.38 \mathrm{E}+01$ & $1.09 \mathrm{E}+01$ \\
\hline PBW2-1 & 1 & 29-Jul & $6.00 \mathrm{E}+01$ & $6.76 \mathrm{E}+01$ & $1.89 \mathrm{E}+01$ \\
\hline PBW3-1 & 1 & 29-Jul & $3.00 \mathrm{E}+01$ & $3.89 E+01$ & $1.61 E+01$ \\
\hline PBW3-2 & 2 & 29-Jul & $4.00 \mathrm{E}+01$ & $7.73 E+01$ & $2.20 \mathrm{E}+01$ \\
\hline PBW4-1 & 1 & 29-Jul & $5.00 \mathrm{E}+01$ & $5.22 \mathrm{E}+01$ & $2.07 \mathrm{E}+01$ \\
\hline PBW4-2 & 2 & 29-Jul & $5.00 \mathrm{E}+01$ & $6.19 \mathrm{E}+01$ & $2.09 \mathrm{E}+01$ \\
\hline PBW5-1 & 1 & 29-Jul & $5.00 \mathrm{E}+01$ & $5.81 \mathrm{E}+01$ & $2.07 \mathrm{E}+01$ \\
\hline \multicolumn{6}{|c|}{ Pond B Sediments: } \\
\hline PBS1-1 & 1 & 29-Jul & $6.00 \mathrm{E}+01$ & $1.65 \mathrm{E}+04$ & $5.24 \mathrm{E}+02$ \\
\hline PBS1-1B & 1 & 29-Jul & $7.00 \mathrm{E}+01$ & $1.39 E+04$ & $4.42 E+02$ \\
\hline PBS2-1 & 1 & 29-Jul & $8.00 E+01$ & $2.11 \mathrm{E}+04$ & $6.70 \mathrm{E}+02$ \\
\hline
\end{tabular}

'Minimum Detectable Activity. 
The background concentration of a given element in soil represents the concentration present after the soil was formed and underwent some degree of weathering. It gives no indication of the maximum concentration of the element that a soil can immobilize, i.e., the element loading capacity of the soil. Background radionuclides fall into three categories: (1) naturally occurring isotopes, (2) global man-made isotopes dispersed as atmospheric fallout from nuclear weapons testing, and (3) constituents potentially released from the site and deposited by atmospheric fallout.

In 1996, a background soil radionuclide data set specific to SRS was compiled from ongoing investigations in the SRS environmental restoration program (PRC 1996), Table 8. Background sediment data was collected during the Comprehensive Cooling Water Study in the 1980s (DuPont 1985 and DuPont 1987). These data sets were used to compare with results from the July 1998 sampling of soil on and around Pond B dam. The radioisotopes detected in surface soils at the Pond B dam are within the range typically found in nationwide and SRS specific soil surveys as shown in Table 8. Cesium-137 measured in the dam samples was within SRS and national background levels. Potassium-40 found in the dam samples also was within SRS and national background levels. Gross alpha, gross beta, ${ }^{60} \mathrm{Co}$ and ${ }^{212} \mathrm{~Pb}$ levels were within SRS background levels, though national background levels were not available for comparison. No background data for ${ }^{212} \mathrm{Bi},{ }^{214} \mathrm{Bi},{ }^{214} \mathrm{~Pb}$ and ${ }^{208} \mathrm{Tl}$ were available for comparison.

Table 8. Nationwide and SRS Background Soil Radioisotope Concentrations Compared to Pond B

\begin{tabular}{|l|c|c|c|c|}
\hline \multicolumn{1}{|c|}{ Constituent } & $\begin{array}{c}\text { Nationwide Soils } \\
\text { (pCi/kg) }\end{array}$ & $\begin{array}{c}\text { SRS Background } \\
\text { Soils }\end{array}$ & $\begin{array}{c}\text { Pond B Sediment } \\
\text { (pCi/kg) }\end{array}$ & $\begin{array}{c}\text { Pond B Dam } \\
\text { (pCi/kg) }\end{array}$ \\
\hline Gross Alpha & NA & $<10$ to $44,530^{2}$ & 2,597 & $<$ MDA to 16,600 \\
\hline Nonvolatile Beta & NA & $<10$ to $54,820^{2}$ & 15,000 & $<$ MDA to 10,100 \\
\hline Actinium-228 & NA & $<10$ to $2,540^{2}$ & 1,277 & $<$ MDA to 2,760 \\
\hline Bismuth-212 & NA & NA & 799 & $<$ MDA to 2,460 \\
\hline Bismuth-214 & NA & NA & 845 & <MDA to 1,740 \\
\hline Cobalt-60 & NA & $<4,000^{3}$ & 45 & $<$ MDA \\
\hline Cesium-137 & 10 to 3,500 & $<0.3$ to $2,210^{2}$ & 17,167 & $<$ MDA to 284 \\
\hline Potassium-40 & 3,000 to 20,000 & 66 to $11,600^{2}$ & 619 & $<$ MDA to 5,950 \\
\hline Lead-212 & NA & 13 to $3,200^{2}$ & 1,210 & <MDA to 2,620 \\
\hline Lead-214 & NA & NA & 798 & <MDA to 1,770 \\
\hline Thallium-208 & NA & NA & 451 & <MDA to 938 \\
\hline
\end{tabular}

'EPA 1994

${ }^{2}$ PRC 1996.

${ }^{3}$ Meyer's Branch sediment data, DuPont, 1987. Used as background soil data in WSRC 1992.

${ }^{4}$ Average of Pond B sediment data from EMS, this report-Appendix B.

${ }^{5}$ EMS data, this report - Appendix B.

${ }^{6} \mathrm{MDA}=$ Minimum detectable activity.

$7 \mathrm{NA}=$ Not available 


\section{Dose Estimate for Pond B Dam Workers}

Using the data from the July 1998 sampling program, the maximum potential dose to a person working on the dam and directly exposed to radioactivity in the soil was estimated (Table 9). For the soil samples taken from the Pond B dam area and analyzed by EMS, ${ }^{60} \mathrm{Co},{ }^{137} \mathrm{Cs}$, gross beta, gross alpha and several naturally occurring radionuclides were detected. The numerical average was used for dose calculations (DOE 1991). Doses for various naturally occurring radionuclides were not calculated separately since they were contained in the gross alpha and gross beta determinations. Pond sediment samples were excluded since there will be no work in the pond during the dam repair. Conservatively, the gross beta was assumed to be ${ }^{90} \mathrm{Sr}$ and the gross alpha was assumed to be ${ }^{239} \mathrm{Pu}$. The total potential dose from inhalation, ingestion, dermal absorption and ground shine pathways was conservatively estimated to be about 32 mrem per year, which is below all regulatory requirements. Dose calculations also assumed that a worker performs construction activity at Pond $\mathrm{B}$ eight hours per day for 250 days per year.

The various worker dose pathways are described below.

Inhalation Pathway: There will be no inhalation dose unless the soil is dry and resuspended into the air. Under the worst case scenario, the worker would be exposed to the nuisance dust limit of $10 \mathrm{mg} / \mathrm{m}^{3} \mathrm{of}$ air. Assuming a breathing rate of $9.6 \mathrm{~m}^{3}$ per 8 hour work period (Huang and Marter 1983), and using a published inhalation dose factor (DOE 1988a), the potential dose from the inhalation pathway would be $31 \mathrm{mrem} / \mathrm{yr}$.

Ingestion Pathway: $\quad$ EPA risk assessments commonly assume that a worker will ingest $0.05 \mathrm{~g}$ of contaminated soil each workday (WSRC 1992). Using a published ingestion dose factor (DOE 1988a), the potential dose from the ingestion pathway would be $0.14 \mathrm{mrem} / \mathrm{yr}$.

Dermal Absorption Pathway: Equation variables from a risk evaluation of Par Pond surface water and exposed sediments (WSRC 1992) can be used to determine the worker dose from the dermal absorption pathway. It can be assumed that $3,120 \mathrm{~cm}^{2}$ of the worker's skin (hands and arms) comes in contact with soil. The soil to skin adherence factor is $2.77 \mathrm{mg} / \mathrm{cm}^{2}$ and the absorption factor is 0.03 . Using a published ingestion dose factor (this assumes a similar body distribution for ingestion and dermal absorption) the potential dose from the dermal absorption pathway would be $0.71 \mathrm{mrem} / \mathrm{yr}$.

Ground Shine Dose: The ground shine dose can be estimated in a very crude and conservative manner by assuming that the radioactivity is uniformly distributed in the top $15 \mathrm{~cm}$ of the soil, no radioactivity is located at greater depths, and the soil density is $2 \mathrm{~g} / \mathrm{cm}^{3}$. The area of contamination is assumed to be an infinite plane and no credit is taken for absorption of the gamma radiation in the soil. Using published information (DOE 1988b), the potential dose one meter above the surface would be $0.18 \mathrm{mrem} / \mathrm{yr}$. 


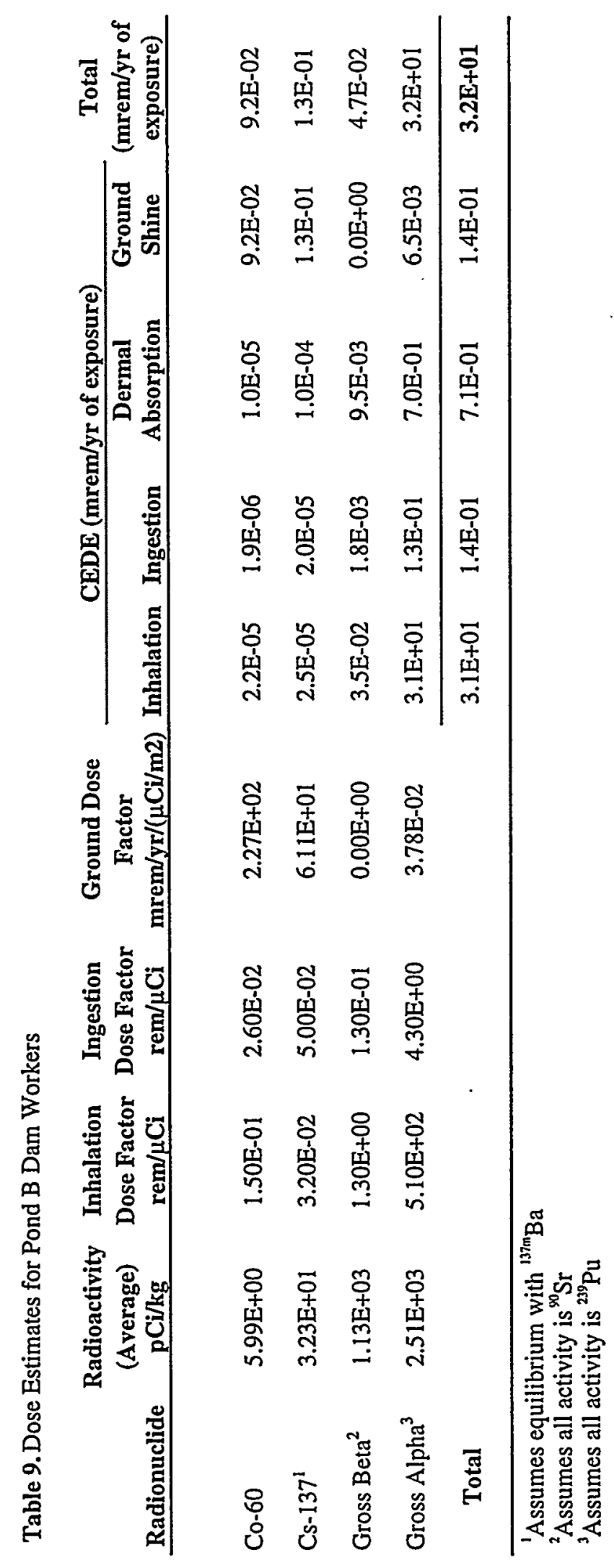




\section{Summary}

The current proposal to fix and repair the Pond B dam structure involves stripping topsoil and vegetation from the face of the dam and from at least a 50 to 100 foot area along the toe of the dam. Then the dam would be reinforced with additional pervious material on the downstream face of the dam. Roughly 3.4 acres of wetlands would be impacted by the extension of the toe of the dam 100 yards into the wetlands from the existing toe of the dam.

Previous studies on SRS soils in general (Looney et al. 1985) and Pond B in particular (Whicker et al, 1990) indicated that mobility of ${ }^{137} \mathrm{Cs}$ through Pond B sediments should be expected to be very low. Consequently, ${ }^{137} \mathrm{Cs}$ would not be expected to migrate from Pond B through the dam with the seepage water. Results from the Pond B sediment samples and Pond B dam soil samples collected in July 1998 support the findings of these previous studies. Radioisotope levels measured in the dam soil samples were within background levels for SRS. While this finding supports the presupposition that contamination has not spread from Pond B water to the top layer of soil on the downstream side of the dam, it does not rule out the possibility that very small levels or radioactivity have migrated with the seepage water.

Actual levels of activity found in the samples were used to calculate potential dose to a person working on the dam during the proposed dam repair project. The maximum potential dose was conservatively calculated to be $32 \mathrm{mrem}$ per year, which is below regulatory requirements.

The Pond B Dam repair project work will be performed according to site procedures. 


\section{References}

Carlton, W. H., L. R. Bauer, A. G. Evans, L. A. Geary, C. E. Murphy, Jr., J. E. Pinder, and R. N. Strom, 1992. “Cesium In The Savannah River Site Environment (U)", WSRC-RP-92-250. Westinghouse Savannah River Company, Aiken, SC.

DOE (U.S. Department of Energy), 1988a. "Internal Dose Conversion Factors for Calculation of Dose to the Public", DOE/EH-0071, Washington, DC.

DOE (U.S. Department of Energy), 1988b. "External Dose-Rate Conversion Factors for Calculation of Dose to the Public", DOE/EH-0070. Washington, DC.

DOE (U.S. Department of Energy), 1991. "Environmental Regulatory Guide for Radiological Effluent Monitoring and Environmental Surveillance", DOE/EH-0173T. Washington, DC.

Dragun, J., 1988, "The Soil Chemistry of Hazardous Materials" ( $1^{\text {st }}$ ed.). The Hazardous Materials Control Research Institute, Silver Spring, Maryland.

DuPont (E. I. DuPont de Nemours \& Co.), 1985. Comprehensive Cooling Water Study Annual Report, Vol. 4: Radionuclide and Heavy Metal Transport. DP-1697-4. E. I. DuPont de Nemours \& Co., Aiken, SC.

DuPont (E. I. DuPont de Nemours \& Co.), 1987. Comprehensive Cooling Water Study Final Report, Vol. 3: Radionuclide and Heavy Metal Transport. DP-1739-3. E. I. DuPont de Nemours \& Co., Aiken, SC.

EPA (U.S. Environmental Protection Agency), 1994. Radionuclide Site Cleanup Regulations, Technical Support Document for the Development of Radionuclide Cleanup Levels for Soil. Review Draft. U.S. Environmental Protection Agency, Washington, DC

Grim, R. E., 1968, "Clay Mineralogy" (2 ${ }^{\text {nd }}$ ed.). McGraw-Hill Book Co., New York.

Halverson , N. V., L. D. Wike, K. K. Patterson, J. A. Bowers, A. L. Bryan, K. F. Chen, C. L. Cummins, B. R. del Carmen, K. L. Dixon, D. L. Dunn, G. P. Friday, J. E. Irwin, R. K. Kolka, H. E. Mackey, Jr., J. J. Mayer, E. A. Nelson, M. H. Paller, V. A. Rogers, W. L. Specht, H. M. Westbury, and E. W. Wilde, 1998, "The Ecology Environmental Information Document," WSRC-TR-97-0223. Westinghouse Savannah River Company, Aiken, SC.

Huang, J.C. and W.L. Marter, 1983. "Recommended Breathing Rates for SAR Accident Dose Calculations,". DPST-83930. Savannah River Laboratory, E.I. Du Pont de Nemours \& Co., Aiken SC.

Looney, B. B., M. V. Grant, and C. M. King, 1985, "Estimation of Geochemical Parameters for Assessing Subsurface Transport at the Savannah River Plant", DPST-85-904. E.I. du Pont de Nemours \& Co., Savannah River Laboratory, Aiken, S.C.

Moore, F. S., 1998. “Gamma Scan of B Pond Soil Samples," SRT-ADS-98-0380. Personal memo dated August 6, 1998.

Pinder, J. E. III, J. W. Bowling, R. F. Lide, and L. M. Beatty, 1995. The Distribution of ${ }^{137} \mathrm{Cs}$ in Sediments of the Littoral Zone of a Former Reactor Cooling Pond. J. Environmental Radioactivity 28(1).

PRC (PRC Environmental Management, Inc.), 1996. Preliminary Background Soils Study Report. Prepared for the U.S. Department of Energy, Savannah River Operations Office. Environmental Restoration Division, Aiken, SC.

Whicker, F. W, J. E. Pinder III, J. W. Bowling, J. J. Alberts, and I. L. Brisbin Jr., 1990. Distribution of Long-Lived Radionuclides in an Abandoned Reactor Cooling Reservoir. Ecological Monographs, 60(4).

WSRC 1992. "Baseline Risk Assessment Using Existing Data for Par Pond," WSRC-RP-91-1197. Revision 1, Westinghouse Savannah River Corporation, Aiken, SC.

WSRC 1997. "Savannah River Site Environmental Data for 1996," WSRC-TR-97-0077. Westinghouse Savannah River Corporation, Aiken, SC. 


\section{Appendix A:} Sample Listing 


\section{SAMPLE LABELING}

The sample number as described below identified all samples. The sample number is designed to identify the sample location, sampling interval and type of sample.

Sample numbering scheme: Project, Location - Interval, Type

The individual elements are explained below:

Project $\quad \mathrm{PB}=$ Pond $\mathrm{B}$ project

Locations $\quad \mathrm{U} 1=$ Upper Transect, marker \#1

L1 = Lower Transect, marker \#1

$\mathrm{Wl}=$ Wooded area downstream, first marker away the dam

$\mathrm{S} 1=$ Pond sediment location 1

Intervals $\quad 1$ - First sampling interval $\quad 0-1$ foot

2 - Second sampling interval $2-4$ feet

3 - Third sampling interval $\quad 4-10$ feet

Type $\quad \mathrm{A}=$ Archive

$\mathrm{B}=$ Replicate

$\mathrm{C}=$ Split for GEL analysis 


\section{Listing of Samples}

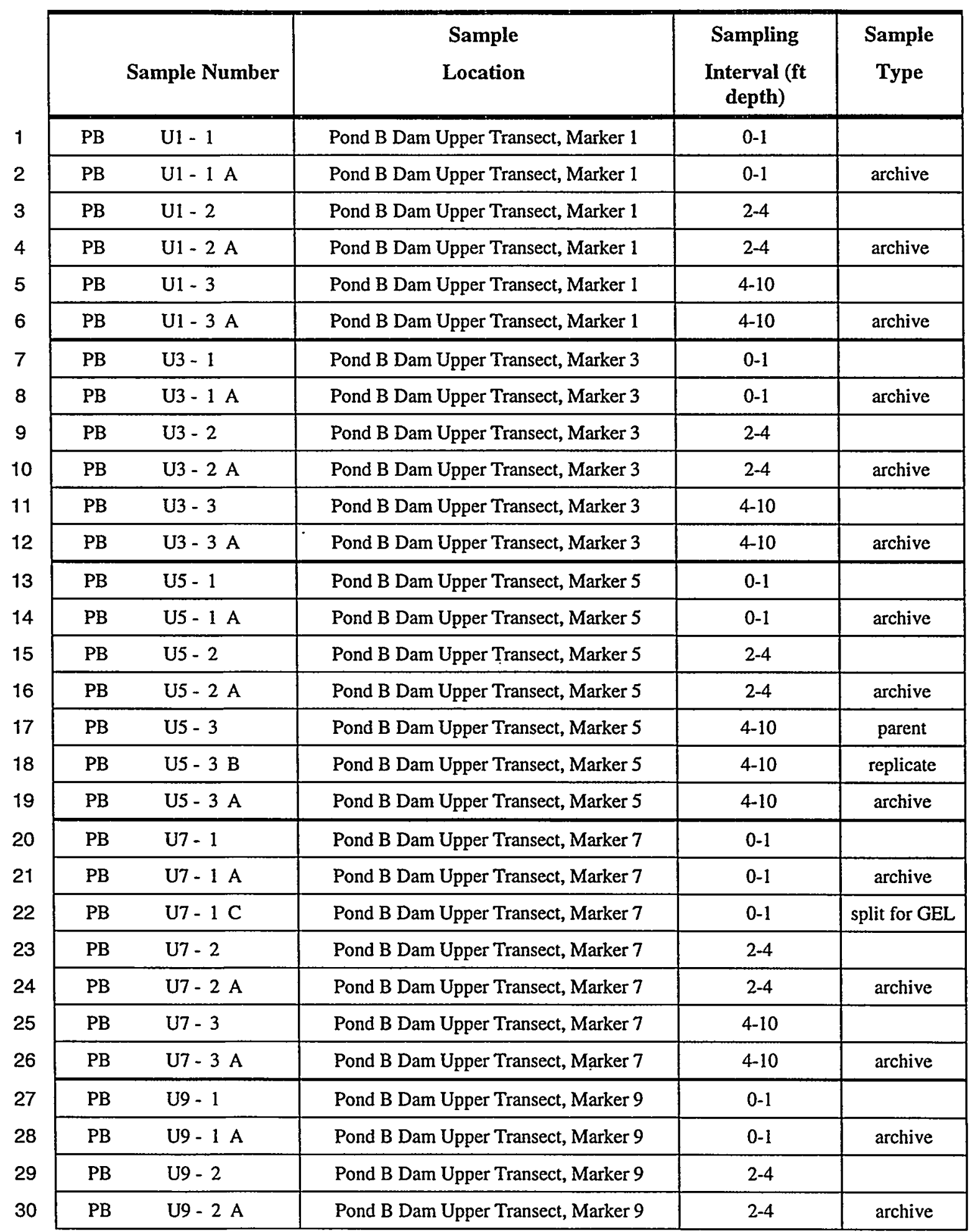




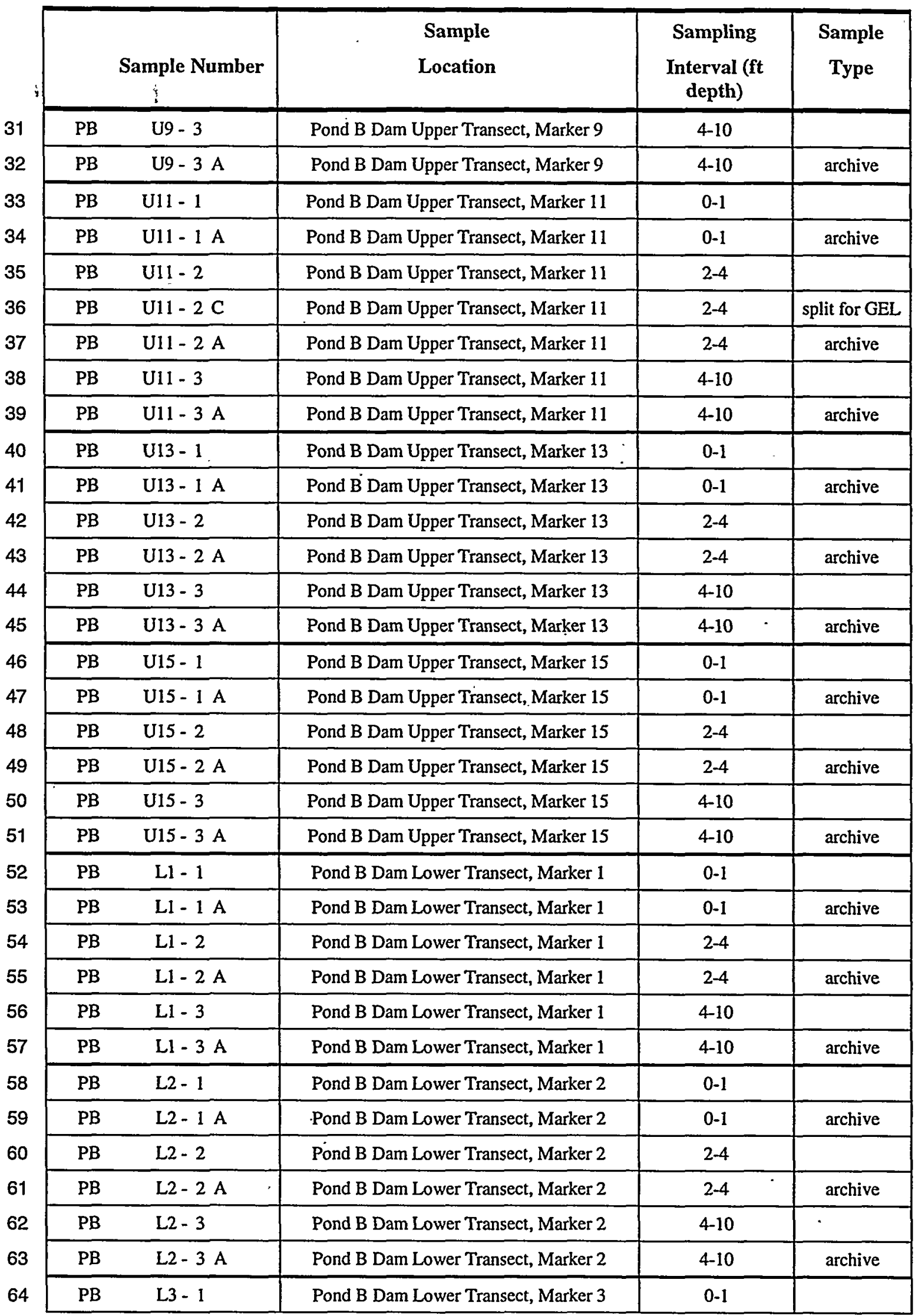




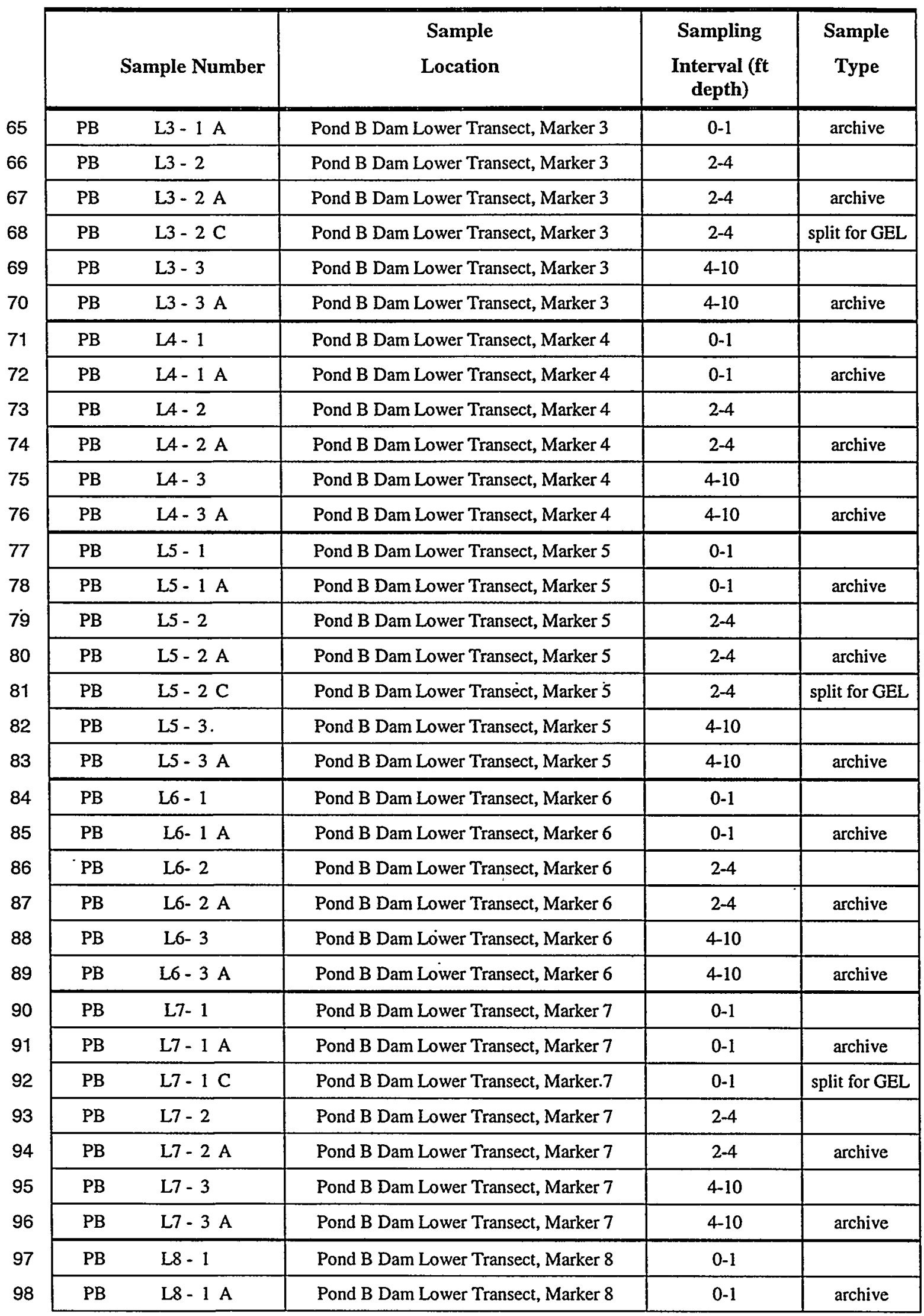




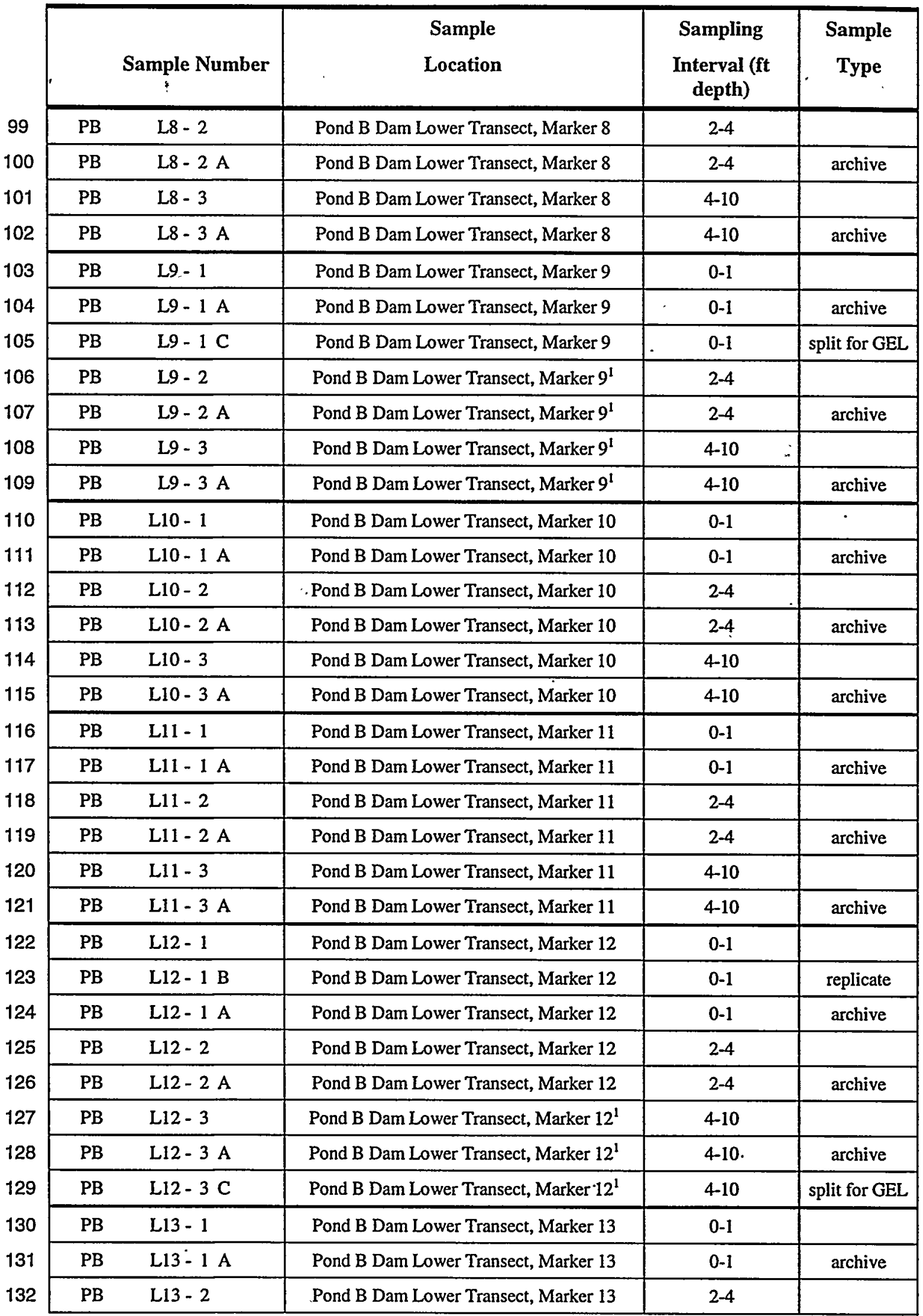




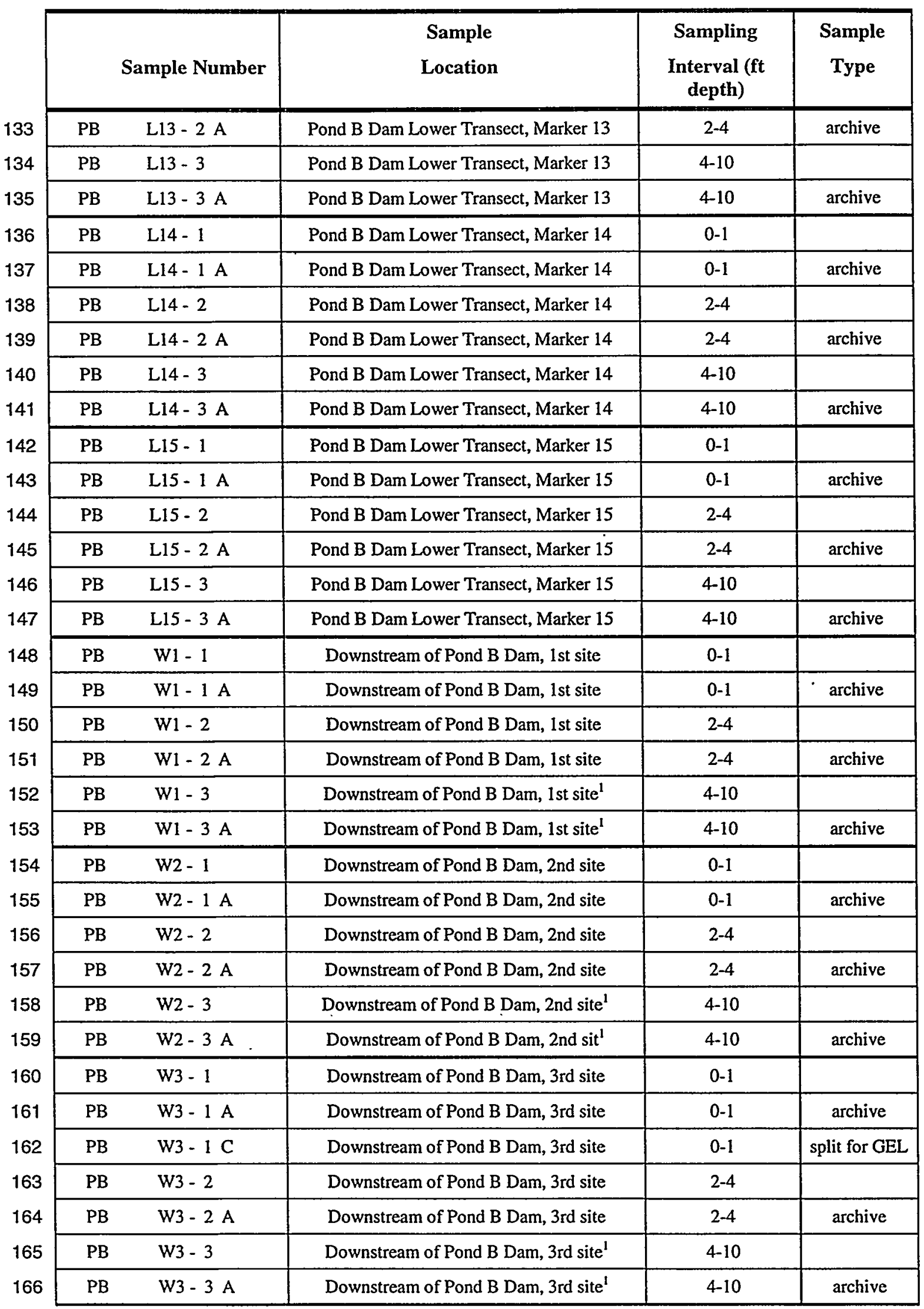




\begin{tabular}{|c|c|c|c|c|c|}
\hline \multirow[b]{2}{*}{167} & \multicolumn{2}{|c|}{ Sample Number } & \multirow{2}{*}{$\begin{array}{c}\text { Sample } \\
\text { Location } \\
\text { Downstream of Pond B Dam, 4th site }\end{array}$} & \multirow{2}{*}{$\begin{array}{l}\text { Sampling } \\
\text { Interval (ft } \\
\text { depth) } \\
0-1\end{array}$} & \multirow[t]{2}{*}{$\begin{array}{c}\text { Sample } \\
\text { Type }\end{array}$} \\
\hline & PB & W4 - 1 & & & \\
\hline 168 & PB & W4- $1 \mathrm{~A}$ & Downstream of Pond B Dam, 4th site & $0-1$ & archive \\
\hline 169 & $\mathrm{~PB}$ & W4 - 2 & Downstream of Pond B Dam, 4th site & $2-4$ & \\
\hline 170 & $\mathrm{~PB}$ & W4 - $2 \mathrm{~A}$ & Downstream of Pond B Dam, 4th site & $2-4$ & archive \\
\hline 171 & PB & W4 - 3 & Downstream of Pond B Dam, 4th site ${ }^{1}$ & $4-10$ & \\
\hline 172 & $\mathrm{~PB}$ & W4- $3 A$ & Downstream of Pond B Dam, 4th site ${ }^{l}$ & $4-10$ & archive \\
\hline 173 & $\mathrm{~PB}$ & $W 4-3 C$ & Downstream of Pond B Dam, 4th site & $4-10$ & split for GEL \\
\hline 174 & $\mathrm{~PB}$ & W5 - 1 & Downstream of Pond B Dam, 5th site & $0-1$ & \\
\hline 175 & $\mathrm{~PB}$ & W5 - $1 \mathrm{~A}$ & Downstream of Pond B Dam, 5th site & $0-1$ & archive \\
\hline 176 & $\mathrm{~PB}$ & W5 - 2 & Downstream of Pond B Dam, 5th site & $2-4$ & \\
\hline 177 & $\mathrm{~PB}$ & W5 - $2 A$ & Downstream of Pond B Dam, 5th site & $2-4$ & archive \\
\hline 178 & $\mathrm{~PB}$ & W5 - 3 & Downstream of Pond B Dam, 5th site & $4-10$ & \\
\hline 179 & $\overline{\mathrm{PB}}$ & W5 - 3 A & Downstream of Pond B Dam, 5th site & $4-10$ & archive \\
\hline 180 & PB & $S 1-1$ & Pond B near Dam, location 1 & shallow & \\
\hline 181 & PB & $\mathrm{S} 1-1 \mathrm{~B}$ & Pond B near Dam, location 1 & shallow & replicate \\
\hline 182 & $\mathrm{~PB}$ & $S 1-1 A$ & Pond B near Dam, location 1 & shallow & archive \\
\hline 183 & PB & $s 2-1$ & Pond B near Dam, location 2 & shallow & \\
\hline 184 & PB & $S 2-1 C$ & Pond B near Dám, location 2 & shallow & split for GEL \\
\hline 185 & PB & $S 2-1 \mathrm{~A}$ & Pond B near Dam, location 2 & shallow & archive \\
\hline
\end{tabular}

${ }^{1}$ Sample could not be collected. 
Appendix B:

EMS Analytical Data 


\section{EMS ANALYTICAL DATA}

\section{Analytical Data Table Nomenclature}

Laboratory results are presented for each sample collected. For each analyte in the laboratory analyses tables, the following information is presented:

Sample Number: The WSRC Sample Identification Number

Trans. D: Transect identification number.

Depth Int.: · Depth interval.

1 - First sampling interval $\quad 0-1$ foot

2 - Second sampling interval $2-4$ feet

3 - Third sampling interval 4 - 10 feet

Anal. Lab ID: Analytical Laboratory identification number. Internal sample number used in the EMS lab.

Date: Date the sample was collected.

Analyte: $\quad$ Parameter measured.

DL (pCi/kg): Detection Limit. The detection limit is the minimum concentration of a substance that can be identified, measured, and reported with $99 \%$ confidence that the analyte concentration is above zero. It answers the question, "Is it present".

Qual.: Qualifier. Letter indicating special conditions associated with the result

If the final concentration in the sample was found to be below the detection limit, the value reported is flagged with a " $U$ " qualifier.

Activity (pCi/kg): Measured result of the analysis

1 Sigma (pCi/kg): One standard deviation 


\section{EMS Analytical Data}

Lower Tier

\begin{tabular}{|c|c|c|c|c|c|c|c|c|c|}
\hline $\begin{array}{r}\text { Sample } \\
\text { Number }\end{array}$ & $\begin{array}{c}\text { Trans. } \\
\text { ID }\end{array}$ & $\begin{array}{c}\text { Depth } \\
\text { Int. }\end{array}$ & $\begin{array}{c}\text { Anal. Lab } \\
\text { ID }\end{array}$ & Date & Analyte & $\mathrm{DL}(\mathrm{pCi} / \mathrm{kg})$ & Qual. & $\begin{array}{l}\text { Activity } \\
\text { (pCi/kg) }\end{array}$ & $\begin{array}{c} \pm 1 \text { Sigma } \\
(\mathrm{pCi} / \mathrm{kg})\end{array}$ \\
\hline PBL1-1 & 1 & 1 & 98809745 & 28-Jul C & Gross A & 5530 & & $9.16 \mathrm{E}+03$ & $2.69 \mathrm{E}+03$ \\
\hline PBL1-1 & 1 & 1 & 98809745 & 28-Jul C & Gross B & 9640 & $U$ & $1.06 \mathrm{E}+03$ & $2.78 E+03$ \\
\hline PBL1-1 & 1 & 1 & 98809745 & 28-Jul & Ac-228 & 140 & & $1.07 \mathrm{E}+03$ & $8.14 \mathrm{E}+01$ \\
\hline PBL1-1 & 1 & 1 & 98809745 & 28-Jul I & $\mathrm{Bi}-212$ & 380 & & $6.73 E+02$ & $1.59 \mathrm{E}+02$ \\
\hline PBL1-1 & 1 & 1 & 98809745 & 28-Jul & $\mathrm{Bi}-214$ & 90 & & $8.43 E+02$ & $5.73 E+01$ \\
\hline PBL1-1 & 1 & 1 & 98809745 & 28-Jul & $\mathrm{Co}-60$ & 50 & $\mathrm{U}$ & $5.65 \mathrm{E}+00$ & $1.23 \mathrm{E}+01$ \\
\hline PBL1-1 & 1 & 1 & 98809745 & 28-Jul & Cs-137 & 60 & $\mathrm{U}$ & $-8.95 E+00$ & $1.58 \mathrm{E}+01$ \\
\hline PBL1-1 & 1 & 1 & 98809745 & 28-Jul & $\mathrm{K}-40$ & 300 & & $8.65 E+02$ & $2.20 \mathrm{E}+02$ \\
\hline PBL1-1 & 1 & 1 & 98809745 & 28-Jul & $\mathrm{Pb}-212$ & 90 & & $1.09 \mathrm{E}+03$ & $7.46 E+01$ \\
\hline PBL1-1 & 1 & 1 & 98809745 & 28-Jul & $\mathrm{Pb}-214$ & 110 & & $8.35 E+02$ & $6.92 E+01$ \\
\hline PBL1-1 & 1 & 1 & 98809745 & 28-Jul & T1-208 & 50 & & $3.49 \mathrm{E}+02$ & $3.69 \mathrm{E}+01$ \\
\hline PBL1-2 & 1 & 2 & 98809743 & 28-Jul & Gross A & 5460 & U & $5.41 E+03$ & $2.14 \mathrm{E}+03$ \\
\hline PBL1-2 & 1 & 2 & 98809743 & $28-J u l$ & Gross B & 9590 & $\mathrm{U}$ & $3.59 \mathrm{E}+03$ & $2.92 \mathrm{E}+03$ \\
\hline PBL1-2 & 1 & 2 & 98809743 & 28-Jul & Ac-228 & 160 & & $1.01 E+03$ & $8.08 \mathrm{E}+01$ \\
\hline PBL1-2 & 1 & 2 & 98809743 & 28-Jul & $\mathrm{Bi}-212$ & 370 & & $6.54 \mathrm{E}+02$ & $1.74 \mathrm{E}+02$ \\
\hline PBL1-2 & 1 & 2 & 98809743 & 28-Jul & $\mathrm{Bi}-214$ & 100 & & $7.51 E+02$ & $6.14 E+01$ \\
\hline PBL1-2 & 1 & 2 & 98809743 & 28-Jul & Co-60 & 50 & $\mathrm{U}$ & $1.40 \mathrm{E}+01$ & $1.23 \mathrm{E}+01$ \\
\hline PBL1-2 & 1 & 2 & 98809743 & 28-Jul & Cs- 137 & 50 & $\mathrm{U}$ & $-3.05 E+01$ & $1.49 E+01$ \\
\hline PBL1-2 & 1 & 2 & 98809743 & 28-Jul & $\mathrm{K}-40$ & 410 & & $8.95 E+02$ & $2.43 E+02$ \\
\hline PBL1-2 & 1 & 2 & 98809743 & 28-Jul & $\mathrm{Pb}-212$ & 100 & & $9.81 E+02$ & $7.23 E+01$ \\
\hline PBL1-2 & 1 & 2 & 98809743 & 28-Jul & $\mathrm{Pb}-214$ & 100 & & $8.43 E+02$ & $6.68 \mathrm{E}+01$ \\
\hline PBL1-2 & 1 & 2 & 98809743 & 28-Jul & $\mathrm{Tl}-208$ & 50 & & $3.65 \mathrm{E}+02$ & $3.61 \mathrm{E}+01$ \\
\hline PBL1-3 & 1 & 3 & 98809746 & 28-Jul & Gross A & 5430 & $\mathrm{U}$ & $8.81 E+02$ & $1.35 \mathrm{E}+03$ \\
\hline PBL1-3 & 1 & 3 & 98809746 & 28-Jul & Gross B & 9560 & $\mathrm{U}$ & $2.78 \mathrm{E}+03$ & $2.82 E+03$ \\
\hline PBL1-3 & 1 & 3 & 98809746 & 28-Jul & Ac-228 & 160 & & $1.03 \mathrm{E}+03$ & $8.72 \mathrm{E}+01$ \\
\hline
\end{tabular}




\begin{tabular}{|c|c|c|c|c|c|c|c|c|c|}
\hline $\begin{array}{c}\text { Sample } \\
\text { Number }\end{array}$ & $\begin{array}{c}\text { Trans. } \\
\text { ID }\end{array}$ & $\begin{array}{l}\text { Depth } \\
\text { Int. }\end{array}$ & $\begin{array}{c}\text { Anal. Lab } \\
\text { ID }\end{array}$ & Date & Analyte & $\mathrm{DL}(\mathrm{pCi} / \mathrm{kg})$ & Qual. & $\begin{array}{l}\text { Activity } \\
\text { (pCi/kg) }\end{array}$ & $\begin{array}{c} \pm 1 \text { Sigma } \\
(\mathrm{pCi} / \mathrm{kg})\end{array}$ \\
\hline PBL1-3 & 1 & 3 & 98809746 & 28-Jul & $\mathrm{Bi}-212$ & 350 & & $7.51 \mathrm{E}+02$ & $1.64 \mathrm{E}+02$ \\
\hline PBL1-3 & 1 & 3 & 98809746 & 28-Jul & Bi-214 & 90 & & $7.43 E+02$ & $6.20 \mathrm{E}+01$ \\
\hline PBL1-3 & 1 & 3 & 98809746 & 28-Jul & Co-60 & 50 & $\mathrm{U}$ & $2.11 E+01$ & $1.29 \mathrm{E}+01$ \\
\hline PBL1-3 & 1 & 3 & 98809746 & 28-Jul & Cs-137 & 50 & $\mathrm{U}$ & $-1.93 E+01$ & $1.57 \mathrm{E}+01$ \\
\hline PBL1-3 & 1 & 3 & $\cdot 98809746$ & 28-Jul & $\mathrm{K}-40$ & 350 & & $4.27 \mathrm{E}+02$ & $2.62 \mathrm{E}+02$ \\
\hline PBL1-3 & 1 & 3 & 98809746 & 28-JuI & $\mathrm{Pb}-212$ & 100 & & $1.01 E+03$ & $7.05 E+01$ \\
\hline PBL1-3 & 1 & 3 & 98809746 & 28-Jul & $\mathrm{Pb}-214$ & 100 & & $8.92 \mathrm{E}+02$ & $6.89 E+01$ \\
\hline PBL1-3 & 1 & 3 & 98809746 & 28-Jul & TI-208 & 50 & & $3.84 \mathrm{E}+02$ & $3.77 \mathrm{E}+01$ \\
\hline PBL2-1 & 2 & 1 & 98809744 & 28-Jul & Gross A & 5410 & & $8.46 \mathrm{E}+03$ & $2.58 \mathrm{E}+03$ \\
\hline PBL2-1 & 2 & 1 & 98809744 & 28-Jul & Gross B & 9540 & $\mathrm{U}$ & $8.46 \mathrm{E}+03$ & $3.18 \mathrm{E}+03$ \\
\hline PBL2-1 & 2 & 1 & 98809744 & 28-Jul & Ac-228 & 170 & & $9.76 \mathrm{E}+02$ & $8.34 E+01$ \\
\hline PBL2-1 & 2 & 1 & 98809744 & 28-Jul & $\mathrm{Bi}-212$ & 310 & & $6.41 \mathrm{E}+02$ & $1.88 \mathrm{E}+02$ \\
\hline PBL2-1 & 2 & 1 & 98809744 & 28-Jul & $B i-214$ & 100 & & $7.46 \mathrm{E}+02$ & $6.73 E+01$ \\
\hline PBL2-1 & 2 & 1 & 98809744 & 28-Jul & Co-60 & 50 & U & $1.79 E+01$ & $1.16 \mathrm{E}+01$ \\
\hline PBL2-1 & 2 & 1 & 98809744 & 28-Jul & Cs-137 & 50 & & $7.81 \mathrm{E}+01$ & $2.95 E+01$ \\
\hline PBL2-1 & 2 & 1 & 98809744 & 28-Jul & $\mathrm{K}-40$ & 490 & & $1.24 \mathrm{E}+03$ & $2.34 \mathrm{E}+02$ \\
\hline PBL2-1 & 2 & 1 & 98809744 & 28-Jul & $\mathrm{Pb}-212$ & 100 & & $9.84 \mathrm{E}+02$ & $6.99 E+01$ \\
\hline PBL2-1 & 2 & 1 & 98809744 & 28-Jul & $\mathrm{Pb}-214$ & 110 & & $8.32 E+02$ & $6.53 E+01$ \\
\hline PBL2-1 & 2 & 1 & 98809744 & 28-Jul & T1-208 & 50 & & $2.86 \mathrm{E}+02$ & $4.18 \mathrm{E}+01$ \\
\hline PBL2-2 & 2 & 2 & 98809747 & 28-Jul & Gross A & 5450 & $\mathrm{U}$ & $1.52 \mathrm{E}+03$ & $1.50 \mathrm{E}+03$ \\
\hline PBL2-2 & 2 & 2 & 98809747 & 28-Jul & Gross B & 9580 & U & $-1.96 E+03$ & $2.58 \mathrm{E}+03$ \\
\hline PBL2-2 & 2 & 2 & 98809747 & 28-Jul & Ac-228 & 140 & & $1.17 \mathrm{E}+03$ & $8.73 E+01$ \\
\hline PBL2-2 & 2 & 2 & 98809747 & 28-Jul & Bi-212 & 300 & & $6.24 \mathrm{E}+02$ & $1.49 \mathrm{E}+02$ \\
\hline PBL2-2 & 2 & 2 & 98809747 & 28-Jul & $\mathrm{Bi}-214$ & 100 & & $7.59 \mathrm{E}+02$ & $5.95 \mathrm{E}+01$ \\
\hline PBL2-2 & 2 & 2 & 98809747 & 28-Jul & Co-60 & 40 & $\mathrm{U}$ & $-1.28 \mathrm{E}+01$ & $1.23 \mathrm{E}+01$ \\
\hline PBL2-2 & 2 & 2 & 98809747 & 28-Jul & Cs-137 & 60 & U & $1.99 \mathrm{E}+01$ & $1.49 \mathrm{E}+01$ \\
\hline PBL2-2 & 2 & 2 & 98809747 & 28-Jul & $\mathrm{K}-40$ & 190 & & $5.43 \mathrm{E}+02$ & $2,53 E+02$ \\
\hline
\end{tabular}




\begin{tabular}{|c|c|c|c|c|c|c|c|c|c|}
\hline $\begin{array}{c}\text { Sample } \\
\text { Number }\end{array}$ & $\begin{array}{c}\text { Trans. } \\
\text { ID }\end{array}$ & $\begin{array}{c}\text { Depth } \\
\text { Int. }\end{array}$ & $\begin{array}{c}\text { Anal. Lab } \\
\text { ID }\end{array}$ & Date & Analyte & DL (pCi/kg) & Qual. & $\begin{array}{l}\text { Activity } \\
(\mathrm{pCi} / \mathrm{kg})\end{array}$ & $\begin{array}{c} \pm 1 \text { Sigma } \\
(\mathrm{pCi} / \mathrm{kg})\end{array}$ \\
\hline PBL2-2 & 2 & 2 & 98809747 & 28-Jul $\mathrm{I}$ & $\mathrm{Pb}-212$ & 100 & & $1.09 \mathrm{E}+03$ & $7.19 \mathrm{E}+01$ \\
\hline PBL2-2 & 2 & 2 & 98809747 & 28-Jul I & $\mathrm{Pb}-214$ & 110 & & $7.05 E+02$ & $5.73 E+01$ \\
\hline PBL2-2 & 2 & 2 & 98809747 & 28-Jul 7 & Tl-208 & 50 & & $3.00 \mathrm{E}+02$ & $3.50 \mathrm{E}+01$ \\
\hline PBL2-3 & 2 & 3 & 98809748 & 28-Jul C & Gross A & 1760 & $\mathrm{U}$ & $9.08 \mathrm{E}+02$ & $5.61 \mathrm{E}+02$ \\
\hline PBL2-3 & 2 & 3 & 98809748 & 28-Jul C & Gross B & 3120 & $\mathrm{U}$ & $1.44 E+02$ & 8.77E+02 \\
\hline PBL2-3 & 2 & 3 & 98809748 & 28-Jul & Ac-228 & 180 & & $1.05 E+03$ & $8.72 \mathrm{E}+01$ \\
\hline PBL2-3 & 2 & 3 & 98809748 & 28-Jul 1 & $\mathrm{Bi}-212$ & 380 & & $7.73 E+02$ & $1.65 \mathrm{E}+02$ \\
\hline PBL2-3 & 2 & 3 & 98809748 & 28-Jul & $B i-214$ & 100 & & $7.51 \mathrm{E}+02$ & $6.00 \mathrm{E}+01$ \\
\hline PBL2-3 & 2 & 3 & 98809748 & 28-Jul & Co- 60 & 50 & $\mathrm{U}$ & $2.22 E+01$ & $1.36 \mathrm{E}+01$ \\
\hline PBL2-3 & 2 & 3 & 98809748 & 28-Jul & Cs-137 & 50 & $\mathrm{U}^{\circ}$ & $-1.63 E+01$ & $1.51 \mathrm{E}+01$ \\
\hline PBL2-3 & 2 & 3 & 98809748 & 28-Jul & $\mathrm{K}-40$ & 420 & & $5.30 \mathrm{E}+02$ & $2.41 \mathrm{E}+02$ \\
\hline PBL2-3 & 2 & 3 & 98809748 & 28-Jul & $\mathrm{Pb}-212$ & 90 & & $9.78 \mathrm{E}+02$ & $6.91 E+01$ \\
\hline PBL2-3 & 2 & 3 & 98809748 & 28-Jul I & $\mathrm{Pb}-214$ & 100 & & $7.41 \mathrm{E}+02$ & $6.14 E+01$ \\
\hline PBL2-3 & 2 & 3 & 98809748 & 28-Jul & Tl-208 & 50 & & $3.46 \mathrm{E}+02$ & $3.32 \mathrm{E}+01$ \\
\hline PBL3-1 & 3 & 1 & 98809830 & 28-Jul & Gross A & 1760 & $\mathrm{U}$ & $1.69 \mathrm{E}+03$ & $6.89 \mathrm{E}+02$ \\
\hline PBL3-1 & 3 & 1 & 98809830 & 28-Jul & Gross B & 3090 & $\mathrm{U}$ & $1.64 \mathrm{E}+02$ & $8.85 \mathrm{E}+02$ \\
\hline PBL3-1 & 3 & 1 & 98809830 & 28-Jul & Ac-228 & 130 & & $1.18 \mathrm{E}+03$ & $4.77 \mathrm{E}+01$ \\
\hline PBL3-1 & 3 & 1 & 98809830 & 28-Jul & $\mathrm{Bi}-212$ & 340 & & $7.86 \mathrm{E}+02$ & $1.07 \mathrm{E}+02$ \\
\hline PBL3-1 & 3 & 1 & 98809830 & 28-Jul & Bi-214 & 80 & & $8.11 E+02$ & $3.81 E+01$ \\
\hline PBL3-1 & 3 & 1 & 98809830 & 28-Jul & Co-60 & 40 & U & $-1.72 E+00$ & $7.34 \mathrm{E}+00$ \\
\hline PBL3-1 & 3 & 1 & 98809830 & 28-Jul & Cs-137 & 60 & $\mathrm{U}$ & $3.46 \mathrm{E}+01$ & $9.96 \mathrm{E}+00$ \\
\hline PBL3-1 & 3 & 1 & 98809830 & 28-Jul & $\mathrm{K}-40$ & 350 & & $1.00 \mathrm{E}+03$ & $1.45 \mathrm{E}+02$ \\
\hline PBL3-1 & 3 & 1 & 98809830 & 28-Jul & $\mathrm{Pb}-212$ & 80 & & $9.65 \mathrm{E}+02$ & $4.20 \mathrm{E}+01$ \\
\hline PBL3-1 & 3 & 1 & 98809830 & 28-Jul & $\mathrm{Pb}-214$ & 90 & & $7.57 \mathrm{E}+02$ & $4.01 E+01$ \\
\hline PBL3-1 & 3 & 1 & 98809830 & 28-Jul & Tl-208 & 40 & & $3.89 \mathrm{E}+02$ & $2.24 \mathrm{E}+01$ \\
\hline PBL3-2 & 3 & 2 & 98809828 & 28-Jul & Gross A & 1760 & $\mathrm{U}$ & $1.12 \mathrm{E}+03$ & $6.08 E+02$ \\
\hline PBL3-2 & 3 & 2 & 98809828 & 28-Jul & Gross B & 3110 & $\mathrm{U}$ & $4.27 E+02$ & $8.92 E+02$ \\
\hline
\end{tabular}




\begin{tabular}{|c|c|c|c|c|c|c|c|c|c|}
\hline $\begin{array}{l}\text { Sample } \\
\text { Number }\end{array}$ & $\begin{array}{c}\text { Trans. } \\
\text { ID }\end{array}$ & $\begin{array}{l}\text { Depth } \\
\text { Int. }\end{array}$ & $\begin{array}{l}\text { Anal. Lab } \\
\text { ID }\end{array}$ & Date & Analyte & $\mathrm{DL}(\mathrm{pCi} / \mathrm{kg})$ & Qual. & $\begin{array}{l}\text { Activity } \\
\text { (pCi/kg) }\end{array}$ & $\begin{array}{c} \pm 1 \text { Sigma } \\
(\mathrm{pCi} / \mathrm{kg})\end{array}$ \\
\hline PBL3-2 & 3 & 2 & 98809828 & 28-Jul & Ac-228 & 120 & & $1.06 \mathrm{E}+03$ & $4.51 E+01$ \\
\hline PBL3-2 & 3 & 2 & 98809828 & 28-Jul & $\mathrm{Bi}-212$ & 280 & & $8.30 \mathrm{E}+02$ & $1.25 E+02$ \\
\hline PBL3-2 & 3 & 2 & 98809828 & 28-Jul & $\mathrm{Bi}-214$ & 80 & & $7.95 \mathrm{E}+02$ & $3.53 \mathrm{E}+01$ \\
\hline PBL3-2 & 3 & 2 & 98809828 & 28-Jul & Co-60 & 30 & $\mathrm{U}$ & $-5.24 \mathrm{E}+00$ & $6.58 \mathrm{E}+00$ \\
\hline PBL3-2 & 3 & 2 & 98809828 & 28-Jul & Cs-137 & 50 & $\mathrm{U}$ & $5.95 \mathrm{E}+00$ & $8.70 E+00$ \\
\hline PBL3-2 & 3 & 2 & 98809828 & 28-Jul & $\mathrm{K}-40$ & 290 & & $9.05 \mathrm{E}+02$ & $1.42 E+02$ \\
\hline PBL3-2 & 3 & 2 & 98809828 & 28-Jul & $\mathrm{Pb}-212$ & 80 & & $1.04 \mathrm{E}+03$ & $4.35 \mathrm{E}+01$ \\
\hline PBL3-2 & 3 & 2 & 98809828 & 28-Jul & $\mathrm{Pb}-214$ & 100 & & $7.78 \mathrm{E}+02$ & $3.95 E+01$ \\
\hline PBL3-2 & 3 & 2 & 98809828 & 28-Jul & Tl-208 & 40. & & $3.19 \mathrm{E}+02$ & $2.22 E+01$ \\
\hline PBL3-3 & 3 & 3 & 98809838 & 28-Jul & Gross A & 2280 & $\mathrm{U}$ & $1.59 \mathrm{E}+03$ & $5.74 \mathrm{E}+02$ \\
\hline PBL3-3 & 3 & 3 & 98809838 & 28-Jul & Gross B & 4020 & $\mathrm{U}$ & $-4.30 E+02$ & $7.82 E+02$ \\
\hline PBL3-3 & 3 & 3 & 98809838 & 28-Jul & Ac-228 & 150 & & $1.00 \mathrm{E}+03$ & $8.86 \mathrm{E}+01$ \\
\hline PBL3-3 & 3 & 3 & 98809838 & 28-Jul & $\mathrm{Bi}-212$ & 370 & & $6.00 \mathrm{E}+02$ & $2.05 \mathrm{E}+02$ \\
\hline PBL3-3 & 3 & 3 & 98809838 & 28-Jul & $\mathrm{Bi}-214$ & 80 & & $8.11 E+02$ & $5.81 E+01$ \\
\hline PBL3-3 & 3 & 3 & 98809838 & 28-Jul & Co-60 & 50 & $\mathrm{U}$ & $7.27 \mathrm{E}+00$ & $1.24 \mathrm{E}+01$ \\
\hline PBL3-3 & 3 & 3 & 98809838 & 28-Jul & Cs-137 & 50 & $\mathrm{U}$ & $1.45 E+01$ & $1.46 \mathrm{E}+01$ \\
\hline PBL3-3 & 3 & 3 & 98809838 & 28-Jul & $\mathrm{K}-40$ & 370 & & $5.89 \mathrm{E}+02$ & $2.36 \mathrm{E}+02$ \\
\hline PBL3-3 & 3 & 3 & 98809838 & 28-Jul & $\mathrm{Pb}-212$ & 100 & & $9.95 E+02$ & $6.92 E+01$ \\
\hline PBL3-3 & 3 & 3 & 98809838 & 28-Jul & $\mathrm{Pb}-214$ & 110 & & $8.19 E+02$ & $6.42 \mathrm{E}+01$ \\
\hline PBL3-3 & 3 & 3 & 98809838 & 28-Jul & Tl-208 & 50 & & $3.24 E+02$ & $3.09 E+01$ \\
\hline PBL4-1 & 4 & 1 & 98809750 & 28-Jul & Gross A & 1560 & & $1.61 \mathrm{E}+03$ & $6.36 \mathrm{E}+02$ \\
\hline PBL4-1 & 4 & 1 & 98809750 & 28-Jul & Gross B & 2620 & $U$ & $4.68 \mathrm{E}+02$ & $7.64 \mathrm{E}+02$ \\
\hline PBL4-1 & 4 & 1 & 98809750 & 28-Jul & Ac-228 & 160 & & $9.49 \mathrm{E}+02$ & $8.11 \mathrm{E}+01$ \\
\hline PBL4-1 & 4 & 1 & 98809750 & 28-Jul & $\mathrm{Bi}-212$ & 380 & & $8.30 \mathrm{E}+02$ & $1.73 E+02$ \\
\hline PBLA-1 & 4 & 1 & 98809750 & 28-Jul & $\mathrm{Bi}-214$ & 90 & & $8.46 \mathrm{E}+02$ & $6.22 E+01$ \\
\hline PBLA-1 & 4 & 1 & 98809750 & 28-Jul & Co-60 & 50 & U & $-1.58 \mathrm{E}+01$ & $1.42 \mathrm{E}+01$ \\
\hline PBLA-1 & 4 & 1 & 98809750 & 28-Jul & Cs-137 & 50 & & $1.02 E+02$ & $3.01 E+01$ \\
\hline
\end{tabular}




\begin{tabular}{|c|c|c|c|c|c|c|c|c|c|}
\hline $\begin{array}{c}\text { Sample } \\
\text { Number }\end{array}$ & $\begin{array}{c}\text { Trans. } \\
\text { ID }\end{array}$ & $\begin{array}{c}\text { Depth } \\
\text { Int. }\end{array}$ & $\underset{\text { ID }}{\text { Anal. Lab }}$ & Date & Analyte & $\mathrm{DL}(\mathrm{pCi} / \mathrm{kg})$ & Qual. & $\begin{array}{l}\text { Activity } \\
\text { (pCi/kg) }\end{array}$ & $\begin{array}{c} \pm 1 \text { Sigma } \\
(\mathrm{pCi} / \mathrm{kg})\end{array}$ \\
\hline PBL4-1 & 4 & 1 & 98809750 & 28-Jul & $\mathrm{K}-40$ & 550 & $\mathrm{U}$ & $3.95 E+02$ & $2.66 \mathrm{E}+02$ \\
\hline PBL4-1 & 4 & 1 & 98809750 & 28-Jul & $\mathrm{Pb}-212$ & 90 & & $9.84 E+02$ & $7.20 \mathrm{E}+01$ \\
\hline PBL4-1 & 4 & 1 & 98809750 & 28-Jul & $\mathrm{Pb}-214$ & 110 & & $8.73 E+02$ & $7.26 \mathrm{E}+01$ \\
\hline PBL4-1 & 4 & 1 & 98809750 & 28-Jul & $\mathrm{Tl}-208$ & 50 & & $4.00 \mathrm{E}+02$ & $3.45 \mathrm{E}+01$ \\
\hline PBL4-2 & 4 & 2 & 98809753 & 28-Jul & Gross A & 1560 & & $1.61 \mathrm{E}+03$ & $6.38 \mathrm{E}+02$ \\
\hline PBL4-2 & 4 & 2 & 98809753 & 28-Jul & Gross B & 2620 & $U$ & $5.54 \mathrm{E}+02$ & $7.65 \mathrm{E}+02$ \\
\hline PBL4-2 & 4 & 2 & 98809753 & 28-Jul & Ac-228 & 150 & & $1.09 \mathrm{E}+03$ & $8.62 E+01$ \\
\hline PBL4-2 & 4 & 2 & 98809753 & 28-Jul & $\mathrm{Bi}-212$ & 380 & & $5.68 \mathrm{E}+02$ & $1.68 \mathrm{E}+02$ \\
\hline PBL4-2 & 4 & 2 & 98809753 & $28-\mathrm{JuI}$ & $B i-214$ & 80 & & $7.27 \mathrm{E}+02$ & $5.53 E+01$ \\
\hline PBL4-2 & 4 & 2 & 98809753 & 28-Jul & Co- 60 & 40 & $U$ & $-2.16 \mathrm{E}+00$ & $1.17 \mathrm{E}+01$ \\
\hline PBL4-2 & 4 & 2 & 98809753 & 28-Jul & Cs-137 & 60 & $\mathrm{U}$ & $4.43 E+01$ & $1.61 \mathrm{E}+01$ \\
\hline PBLA-2 & 4 & 2 & 98809753 & 28-Jul & $\mathrm{K}-40$ & 440 & & $8.78 E+02$ & $3.27 \mathrm{E}+02$ \\
\hline PBL4-2 & 4 & 2 & 98809753 & 28-Jul & $\mathrm{Pb}-212$ & 100 & & $1.05 E+03$ & $7.16 \mathrm{E}+01$ \\
\hline PBLA-2 & 4 & 2 & 98809753 & $28-\mathrm{Jul}$ & $\mathrm{Pb}-214$ & 100 & & $7.81 \mathrm{E}+02$ & $6.05 \mathrm{E}+01$ \\
\hline PBLA-2 & 4 & 2 & 98809753 & 28-Jul & Tl-208 & 40 & & $4.22 \mathrm{E}+02$ & $3.78 \mathrm{E}+01$ \\
\hline PBL4-3 & 4 & 3 & 98809754 & 28-Jul & Gross A & 5430 & $\mathrm{U}$ & $2.76 \mathrm{E}+03$ & $1.78 \mathrm{E}+03$ \\
\hline PBLA-3 & 4 & 3 & 98809754 & 28-Jul & Gross B & 9540 & $\mathrm{U}$ & $-1.12 \mathrm{E}+03$ & $2.62 E+03$ \\
\hline PBLA-3 & 4 & 3 & 98809754 & 28-Jul & Ac-228 & 170 & & $1.16 \mathrm{E}+03$ & $9.55 \mathrm{E}+01$ \\
\hline PBLA-3 & 4 & 3 & 98809754 & 28-Jul & $B i-212$ & 380 & & $9.16 \mathrm{E}+02$ & $1.86 \mathrm{E}+02$ \\
\hline PBLA-3 & 4 & 3 & 98809754 & 28-Jul & $\mathrm{Bi}-214$ & 90 & & $8.65 \mathrm{E}+02$ & $6.30 \mathrm{E}+01$ \\
\hline PBL4-3 & 4 & 3 & 98809754 & 28-Jul & Co-60 & 50 & $\mathrm{U}$ & $-1.08 \mathrm{E}+00$ & $1.29 \mathrm{E}+01$ \\
\hline PBLA-3 & 4 & 3 & 98809754 & 28-Jul & Cs-137 & 50 & $\mathrm{U}$ & $-2.04 \mathrm{E}+01$ & $1.53 \mathrm{E}+01$ \\
\hline PBLA-3 & 4 & 3 & 98809754 & 28-Jul & $\mathrm{K}-40$ & 1180 & $\mathrm{U}$ & $8.89 \mathrm{E}+02$ & $2.70 \mathrm{E}+02$ \\
\hline PBL4-3 & 4 & 3 & 98809754 & 28-Jul & $\mathrm{Pb}-212$ & 110 & & $1.03 \mathrm{E}+03$ & $7.57 \mathrm{E}+01$ \\
\hline PBL4-3 & 4 & 3 & 98809754 & 28-Jul & $\mathrm{Pb}-214$ & 120 & & $6.81 \mathrm{E}+02$ & $6.86 \mathrm{E}+01$ \\
\hline PBL4-3 & 4 & 3 & 98809754 & 28-Jul & TI-208 & 60 & & $3.32 E+02$ & $3.38 \mathrm{E}+01$ \\
\hline PBL5-1 & 5 & 1 & 98809757 & 28-Jul & Gross A & 6700 & $U$ & $4.62 \mathrm{E}+03$ & $1.65 E+03$ \\
\hline
\end{tabular}




\begin{tabular}{|c|c|c|c|c|c|c|c|c|c|}
\hline $\begin{array}{l}\text { Sample } \\
\text { Number }\end{array}$ & $\begin{array}{c}\text { Trans. } \\
\text { ID }\end{array}$ & $\begin{array}{l}\text { Depth } \\
\text { Int. }\end{array}$ & $\begin{array}{c}\text { Anal. Lab } \\
\text { ID }\end{array}$ & Date & Analyte & $\mathrm{DL}(\mathrm{pCi} / \mathrm{kg})$ & Qual. & $\begin{array}{l}\text { Activity } \\
\text { (pCi/kg) }\end{array}$ & $\begin{array}{c} \pm 1 \text { Sigma } \\
(\mathrm{pCi} / \mathrm{kg})\end{array}$ \\
\hline PBL5-1 & 5 & 1 & 98809757 & 28-Jul & Gross B & 11840 & $\mathrm{U}$ & $2 . \hat{8} 4 \mathrm{E}+03$ & $2.46 \mathrm{E}+03$ \\
\hline PBL5-1 & 5 & 1 & 98809757 & 28-Jul & Ac-228 & 160 & & $1.27 \mathrm{E}+03$ & $9.84 \mathrm{E}+01$ \\
\hline PBL5-1 & 5 & 1 & 98809757 & 28-Jul & $\mathrm{Bi}-212$ & 400 & & $9.08 E+02$ & $2.20 \mathrm{E}+02$ \\
\hline PBL5-1 & 5 & 1 & 98809757 & 28-Jul & $\mathrm{Bi}-214$ & 90 & & $9.76 \mathrm{E}+02$ & $6.45 E+01$ \\
\hline PBL5-1 & 5 & 1 & 98809757 & 28-Jul & Co-60 & 50 & $\mathrm{U}$ & $1.46 \mathrm{E}+01$ & $1.27 \mathrm{E}+01$ \\
\hline PBL5-1 & 5 & 1 & 98809757 & 28-Jul & Cs-137 & 60 & & $7.41 \mathrm{E}+01$ & $2.77 E+01$ \\
\hline PBL5-1 & 5 & 1 & 98809757 & 28-Jul & $\mathrm{K}-40$ & 510 & & $1.10 \mathrm{E}+03$ & $2.59 \mathrm{E}+02$ \\
\hline PBL5-1 & 5 & 1 & 98809757 & 28-Jul & $\mathrm{Pb}-212$ & 130 & & $1.07 \mathrm{E}+03$ & $8.05 E+01$ \\
\hline PBL5-1 & 5 & 1 & 98809757 & 28-Jul & $\mathrm{Pb}-214$ & 110 & . & $8.62 \mathrm{E}+02$ & $7.16 \mathrm{E}+01$ \\
\hline PBL5-1 & 5 & 1 & 98809757 & 28-Jul & Tl-208 & 60 & & $4.43 E+02$ & $3.74 \mathrm{E}+01$ \\
\hline PBL5-2 & 5 & 2 & 98809755 & 28-Jul & Gross A & 1760 & $\mathrm{U}$ & $1.55 \mathrm{E}+03$ & $6.74 E+02$ \\
\hline PBL5-2 & 5 & 2 & 98809755 & 28-Jul & Gross B & 3110 & $\mathrm{U}$ & $-1.12 E+03$ & $8.08 E+02$ \\
\hline PBL5-2 & 5 & 2 & 98809755 & 28-Jul & Ac-228. & 140 & & $1.18 \mathrm{E}+03$ & $9.65 \mathrm{E}+01$ \\
\hline PBL5-2 & 5 & 2 & 98809755 & 28-Jul & $\mathrm{Bi}-212$ & 350 & & $6.05 \mathrm{E}+02$ & $1.62 \mathrm{E}+02$ \\
\hline PBL5-2 & .5 & 2 & 98809755 & 28-Jul & Bi-214 & 100 & & $9.49 E+02$ & $6.47 \mathrm{E}+01$ \\
\hline PBL5-2 & 5 & 2 & 98809755 & 28-Jul & Co-60 & 50 & $U$ & $5.65 \mathrm{E}-01$ & $1.24 \mathrm{E}+01$ \\
\hline PBL5-2 & 5 & 2 & 98809755 & 28-Jul & Cs-137 & 60 & $U$ & $2.32 E+01$ & $1.62 \mathrm{E}+01$ \\
\hline PBL5-2 & 5 & 2 & 98809755 & 28-Jul & $\mathrm{K}-40$ & 1030 & U & $4.70 E+02$ & $2.39 \mathrm{E}+02$ \\
\hline PBL5-2 & 5 & 2 & 98809755 & 28-Jul & $\mathrm{Pb}-212$ & 90 & & $1.09 \mathrm{E}+03$ & $7.80 \mathrm{E}+01$ \\
\hline PBL5-2 & 5 & 2 & 98809755 & 28-Jul & $\mathrm{Pb}-214$ & 110 & & $7.92 E+02$ & $6.77 \mathrm{E}+01$ \\
\hline PBL5-2 & 5 & 2 & 98809755 & 28-Jul & Tl-208 & 50 & & $4.97 E+02$ & $3.97 \mathrm{E}+01$ \\
\hline PBL5-3 & 5 & 3 & 98809758 & 28-Jul & Gross A & 1750 & $\mathrm{U}$ & $2.89 \mathrm{E}+02$ & $4.36 \mathrm{E}+02$ \\
\hline PBL5-3 & 5 & 3 & 98809758 & 28-Jul & Gross B & 3100 & U & $-8.00 \mathrm{E}+02$ & $8.26 E+02$ \\
\hline PBL5-3 & 5 & 3 & 98809758 & $28-\mathrm{Jul}$ & Ac-228 & 120 & & $8.38 \mathrm{E}+02$ & $9.22 \mathrm{E}+01$ \\
\hline PBL5-3 & 5 & 3 & 98809758 & 28-Jul & $\mathrm{Bi}-212$ & 320 & & $8.89 E+02$ & $1.72 E+02$ \\
\hline PBL5-3 & 5 & 3 & 98809758 & 28-Jul & Bi-214 & 100 & & $5.62 E+02$ & $6.01 E+01$ \\
\hline PBL5-3 & 5 & 3 & 98809758 & 28-Jul & Co-60 & 50 & $\mathrm{U}$ & $8.59 \mathrm{E}+00$ & $1.26 \mathrm{E}+01$ \\
\hline
\end{tabular}




\begin{tabular}{|c|c|c|c|c|c|c|c|c|c|}
\hline $\begin{array}{c}\text { Sample } \\
\text { Number }\end{array}$ & $\begin{array}{c}\text { Trans. } \\
\text { ID }\end{array}$ & $\begin{array}{c}\text { Depth } \\
\text { Int. }\end{array}$ & $\underset{\text { Anal. Lab }}{\text { AD }}$ & Date & Analyte & $\mathrm{DL}(\mathrm{pCi} / \mathrm{kg})$ & Qual. & $\begin{array}{l}\text { Activity } \\
(\mathrm{pCi} / \mathrm{kg})\end{array}$ & $\begin{array}{c} \pm 1 \text { Sigma } \\
(\mathrm{pCi} / \mathrm{kg})\end{array}$ \\
\hline PBL5-3 & 5 & 3 & 98809758 & 28-Jul & Cs-137 & 50 & $\mathrm{U}$ & $2.28 \mathrm{E}+01$ & $1.36 \mathrm{E}+01$ \\
\hline PBL5-3 & 5 & 3 & 98809758 & 28-Jul & $\mathrm{K}-40$ & 450 & & $4.70 \mathrm{E}+02$ & $2.43 \mathrm{E}+02$ \\
\hline PBL5-3 & 5 & 3 & 98809758 & 28-Jul & $\mathrm{Pb}-212$ & 100 & & $8.54 \mathrm{E}+02$ & $6.69 \mathrm{E}+01$ \\
\hline PBL5-3 & 5 & 3 & 98809758 & $28-\mathrm{Jul}$ & $\mathrm{Pb}-214$ & 110 & & $6.70 \mathrm{E}+02$ & $5.58 \mathrm{E}+01$ \\
\hline PBL5-3 & 5 & 3 & 98809758 & 28-Jul & Tl-208 & 50 & & $2.86 \mathrm{E}+02$ & $3.19 \mathrm{E}+01$ \\
\hline PBL6-1 & 6 & 1 & 98809756 & 28-Jul & Gross A & 1740 & $\mathrm{U}$ & $6.86 \mathrm{E}+02$ & $5.20 \mathrm{E}+02$ \\
\hline PBL6-1 & 6 & 1 & 98809756 & $28-\mathrm{Jul}$ & Gross B & 3080 & $\mathrm{U}$ & $7.41 \mathrm{E}+02$ & $9.00 \mathrm{E}+02$ \\
\hline PBL6-1 & 6 & 1 & 98809756 & 28-Jul & Ac-228 & 180 & & $1.24 \mathrm{E}+03$ & $8.89 \mathrm{E}+01$ \\
\hline PBL6-1 & 6 & 1 & 98809756 & 28-Jul & $\mathrm{Bi}-212$ & 360 & & $6.62 E+02$ & $1.58 \mathrm{E}+02$ \\
\hline PBL6-1 & 6 & 1 & 98809756 & 28-Jul & $\mathrm{Bi}-214$ & 110 & & $7.73 E+02$ & $6.28 \mathrm{E}+01$ \\
\hline PBL6-1 & 6 & 1 & 98809756 & 28-Jul & Co-60 & 60 & $\mathrm{U}$ & $3.30 \mathrm{E}+01$ & $1.39 \mathrm{E}+01$ \\
\hline PBL6-1 & 6 & 1 & 98809756 & 28-Jul & Cs-137 & 40 & & $1.45 \mathrm{E}+02$ & $2.81 \mathrm{E}+01$ \\
\hline PBL6-1 & 6 & 1 & 98809756 & 28-Jul & $\mathrm{K}-40$ & 490 & & $9.73 E+02$ & $2.80 \mathrm{E}+02$ \\
\hline PBL6-1 & 6 & 1 & 98809756 & 28-Jul & $\mathrm{Pb}-212$ & 100 & & $1.08 \mathrm{E}+03$ & $7.72 E+01$ \\
\hline PBL6-1 & 6 & 1 & 98809756 & 28-Jul & $\mathrm{Pb}-214$ & 110 & & $8.05 E+02$ & $6.55 E+01$ \\
\hline PBL6-1 & 6 & 1 & 98809756 & 28-Jul & Tl-208 & 50 & & $3.49 \mathrm{E}+02$ & $3.49 \mathrm{E}+01$ \\
\hline PBL6-2 & 6 & 2 & 98809759 & 28-Jul & Gross A & 1750 & $\mathrm{U}$ & $4.89 \mathrm{E}+02$ & $4.82 \mathrm{E}+02$ \\
\hline PBL6-2 & 6 & 2 & 98809759 & 28-Jul & Gross B & 3110 & $\mathrm{U}$ & $5.86 \mathrm{E}+02$ & $9.08 \mathrm{E}+02$ \\
\hline PBL6-2 & 6 & 2 & 98809759 & 28-Jul & Ac-228 & 200 & & $1.07 \mathrm{E}+03$ & $7.76 \mathrm{E}+01$ \\
\hline PBL6-2 & 6 & 2 & 98809759 & 28-Jul & $\mathrm{Bi}-214$ & 100 & & $7.51 \mathrm{E}+02$ & $6.92 \mathrm{E}+01$ \\
\hline PBL6-2 & 6 & 2 & 98809759 & 28-Jul & Co-60 & 50 & $\mathrm{U}$ & $-2.70 \mathrm{E}+00$ & $1.49 \mathrm{E}+01$ \\
\hline PBL6-2 & 6 & 2 & 98809759 & 28-Jul & Cs-137 & 60 & $\mathrm{U}$ & $-9.38 E+00$ & $1.62 \mathrm{E}+01$ \\
\hline PBL6-2 & 6 & 2 & 98809759 & 28-Jul & $\mathrm{K}-40$ & 430 & & $1.05 E+03$ & $2.59 E+02$ \\
\hline PBL6-2 & 6 & 2 & 98809759 & 28-Jul & $\mathrm{Pb}-212$ & 100 & & $9.54 E+02$ & $7.43 E+01$ \\
\hline PBL6-2 & 6 & 2 & 98809759 & 28-Jul & $\mathrm{Pb}-214$ & 110 & & $8.00 \mathrm{E}+02$ & $6.46 \mathrm{E}+01$ \\
\hline PBL6-2 & 6 & 2 & 98809759 & 28-JuI & Tl-208 & 50 & & $3.38 E+02$ & $3.72 \mathrm{E}+01$ \\
\hline PBL6-3 & 6 & 3 & 98809874 & 28-Jul & Gross A & 1580 & & $3.86 \mathrm{E}+03$ & $9.45 \mathrm{E}+02$ \\
\hline
\end{tabular}




\begin{tabular}{|c|c|c|c|c|c|c|c|c|c|}
\hline $\begin{array}{l}\text { Sample } \\
\text { Number }\end{array}$ & $\begin{array}{c}\text { Trans. } \\
\text { ID }\end{array}$ & $\begin{array}{l}\text { Depth } \\
\text { Int. }\end{array}$ & $\begin{array}{c}\text { Anal. Lab } \\
\text { ID }\end{array}$ & Date & Analyte & $\mathrm{DL}(\mathrm{pCi} / \mathrm{kg})$ & Qual. & $\begin{array}{l}\text { Activity } \\
(\mathrm{pCi} / \mathrm{kg})\end{array}$ & $\begin{array}{c} \pm 1 \text { Sigma } \\
(\mathrm{pCi} / \mathrm{kg})\end{array}$ \\
\hline PBL6-3 & 6 & 3 & 98809874 & 28-Jul & Gross B & 2500 & U & $1.72 \mathrm{E}+03$ & $8.00 \mathrm{E}+02$ \\
\hline PBL6-3 & 6 & 3 & 98809874 & 28-Jul & Ac-228 & 160 & & $1.50 \mathrm{E}+03$ & $1.10 \mathrm{E}+02$ \\
\hline PBL6-3 & 6 & 3 & 98809874 & 28-Jul & $\mathrm{Bi}-212$ & 380 & & $8.46 \mathrm{E}+02$ & $2.30 \mathrm{E}+02$ \\
\hline PBL6-3 & 6 & 3 & 98809874 & 28-Jul & Bi-214 & 100 & & $9.62 E+02$ & $6.58 \mathrm{E}+01$ \\
\hline PBL6-3 & 6 & 3 & 98809874 & 28-Jul & $\mathrm{Co}-60$ & 50 & $\mathrm{U}$ & $1.81 \mathrm{E}+00$ & $1.31 E+01$ \\
\hline PBL6-3 & 6 & 3 & 98809874 & 28-Jul & Cs-137 & 60 & $\mathrm{U}$ & $-4.49 E+00$ & $1.68 \mathrm{E}+01$ \\
\hline PBL6-3 & 6 & 3 & 98809874 & 28-Jul & $\mathrm{K}-40$ & 390 & & $2.04 \mathrm{E}+03$ & $3.08 \mathrm{E}+02$ \\
\hline PBL6-3 & 6 & 3 & 98809874 & 28-Jul & $\mathrm{Pb}-212$ & 100 & & $1.29 \mathrm{E}+03$ & $8.86 \mathrm{E}+01$ \\
\hline PBL6-3 & 6 & 3 & 98809874 & 28-Jul & $\mathrm{Pb}-214$ & 120 & & $1.01 \mathrm{E}+03$ & $7.22 E+01$ \\
\hline PBL6-3 & 6 & 3 & 98809874 & 28-Jul & Tl-208 & 60 & & $4.70 \mathrm{E}+02$ & $4.11 E+01$ \\
\hline PBL7-1 & 7 & 1 & 98810318 & 28-Jul & Gross A & 1400 & $\mathrm{U}$ & $6.19 E+02$ & $4.46 E+02$ \\
\hline PBL7-1 & 7 & 1 & 98810318 & 28-Jul & Gross B & 2420 & $\mathrm{U}$ & $9.03 E+02$ & $7.22 E+02$ \\
\hline PBL7-1 & 7 & 1 & 98810318 & 28-Jul & Ac-228 & 150 & & $9.38 \mathrm{E}+02$ & $7.73 E+01$ \\
\hline PBL7-1 & 7 & 1 & 98810318 & 28-Jul & $\mathrm{Bi}-214$ & 80 & & $7.19 \mathrm{E}+02$ & $6.04 \mathrm{E}+01$ \\
\hline PBL7-1 & 7 & 1 & 98810318 & 28-Jul & Co-60 & 50 & $\mathrm{U}$ & $1.92 \mathrm{E}+01$ & $1.36 \mathrm{E}+01$ \\
\hline PBL7-1 & 7 & 1 & 98810318 & 28-Jul & Cs-137 & 60 & $\mathrm{U}$ & $4.46 \mathrm{E}+01$ & $2.16 \mathrm{E}+01$ \\
\hline PBL7-1 & 7 & 1 & 98810318 & 28-Jul & $\mathrm{K}-40$ & 970 & $\mathrm{U}$ & $2.28 \mathrm{E}+02$ & $2.23 \mathrm{E}+02$ \\
\hline PBL7-1 & 7 & 1 & 98810318 & 28-Jul & $\mathrm{Pb}-212$ & 110 & & $7.86 \mathrm{E}+02$ & $6.61 \mathrm{E}+01$ \\
\hline PBL7-1 & 7 & 1 & 98810318 & 28-Jul & $\mathrm{Pb}-214$ & 110 & & $6.38 \mathrm{E}+02$ & $5.89 \mathrm{E}+01$ \\
\hline PBL7-1 & 7 & 1 & 98810318 & 28-Jul & TI-208 & 50 & & $2.78 \mathrm{E}+02$ & $3.07 \mathrm{E}+01$ \\
\hline PBL7-2 & 7 & 2 & 98810319 & 28-Jul & Gross A & 1940 & $U$ & $1.11 \mathrm{E}+03$ & $4.66 \mathrm{E}+02$ \\
\hline PBL7-2 & 7 & 2 & 98810319 & 28-Jul & Gross B & 3400 & $\mathrm{U}$ & $6.22 E+01$ & $6.72 \mathrm{E}+02$ \\
\hline PBL7-2 & 7 & 2 & 98810319 & 28-Jul & Ac-228 & 110 & & $9.35 \mathrm{E}+02$ & $7.20 \mathrm{E}+01$ \\
\hline PBL7-2 & 7 & 2 & 98810319 & 28-Jul & $B \mathrm{i}-212$ & 380 & & $5.65 \mathrm{E}+02$ & $1.57 \mathrm{E}+02$ \\
\hline PBL7-2 & 7 & 2 & 98810319 & 28-Jul & $\mathrm{Bi}-214$ & 100 & & $6.30 \mathrm{E}+02$ & $5.58 \mathrm{E}+01$ \\
\hline PBL7-2 & 7 & 2 & 98810319 & 28-Jul & Co-60 & 50 & $U$ & $1.91 \mathrm{E}+00$ & $1.23 E+01$ \\
\hline PBL7-2 & 7 & 2 & 98810319 & 28-Jul & Cs-137 & 50 & $\mathrm{U}$ & $1.02 \mathrm{E}+01$ & $1.46 \mathrm{E}+01$ \\
\hline
\end{tabular}




\begin{tabular}{|c|c|c|c|c|c|c|c|c|c|}
\hline $\begin{array}{c}\text { Sample } \\
\text { Number }\end{array}$ & $\begin{array}{c}\text { Trans. } \\
\text { ID }\end{array}$ & $\begin{array}{l}\text { Depth } \\
\text { Int. }\end{array}$ & $\begin{array}{c}\text { Anal. Lab } \\
\text { ID }\end{array}$ & Date & Analyte & $\mathrm{DL}(\mathrm{pCi} / \mathrm{kg})$ & Qual. & $\begin{array}{l}\text { Activity } \\
\text { (pCi/kg) }\end{array}$ & $\begin{array}{c} \pm 1 \text { Sigma } \\
(\mathrm{pCi} / \mathrm{kg})\end{array}$ \\
\hline PBL7-2 & 7 & 2 & 98810319 & 28-Jul & $\mathrm{K}-40$ & 250 & & $7.73 E+02$ & $2.09 \mathrm{E}+02$ \\
\hline PBL7-2 & 7 & 2 & 98810319 & 28-Jul & $\mathrm{Pb}-212$ & 90 & & $9.57 \mathrm{E}+02$ & $7.23 \mathrm{E}+01$ \\
\hline PBL7-2 & 7 & 2 & 98810319 & 28-Jul & $\mathrm{Pb}-214$ & 100 & & $5.84 \mathrm{E}+02$ & $5.59 \mathrm{E}+01$ \\
\hline PBL7-2 & 7 & 2 & 98810319 & 28-Jul & Tl-208 & 50 & & $2.89 \mathrm{E}+02$ & $3.07 \mathrm{E}+01$ \\
\hline PBL7-3 & 7 & 3 & 98810322 & $28-J u l$ & Gross A & 1530 & $\mathrm{U}$ & $1.06 \mathrm{E}+03$ & $5.59 \mathrm{E}+02$ \\
\hline PBL7-3 & 7 & 3 & 98810322 & 28-Jul & Gross B & 2680 & $U$ & $-2.51 \mathrm{E}+02$ & $7.35 \mathrm{E}+02$ \\
\hline PBL7-3 & 7 & 3 & 98810322 & 28-Jul & Ac-228 & 150 & & $9.84 \mathrm{E}+02$ & $8.39 E+01$ \\
\hline PBL7-3 & 7 & 3 & 98810322 & 28-Jul & $\mathrm{Bi}-212$ & 340 & & $5.89 E+02$ & $1.31 E+02$ \\
\hline PBL7-3 & 7 & 3 & 98810322 & 28-Jul & $\mathrm{Bi}-214$ & 80 & & $6.49 E+02$ & $5.77 \mathrm{E}+01$ \\
\hline PBL7-3 & 7 & 3 & 98810322 & 28-Jul & Co-60 & 40 & $\mathrm{U}$ & $1.41 E+01$ & $1.07 E+01$ \\
\hline PBL7-3 & 7 & 3 & 98810322 & 28-Jul & Cs-137 & 50 & $\mathrm{U}$ & $-2.78 \mathrm{E}+01$ & $1.45 \mathrm{E}+01$ \\
\hline PBL7-3 & 7 & 3 & 98810322 & 28-Jul & $\mathrm{K}-40$ & 930 & $\mathrm{U}$ & $3.46 \mathrm{E}+02$ & $2.09 \mathrm{E}+02$ \\
\hline PBL7-3 & 7 & 3 & 98810322 & 28-Jul & $\mathrm{Pb}-212$ & 90 & & $9.68 \mathrm{E}+02$ & $6.76 \mathrm{E}+01$ \\
\hline PBL7-3 & 7 & 3 & 98810322 & 28-Jul & $\mathrm{Pb}-214$ & 110 & & $6.78 \mathrm{E}+02$ & $5.92 \mathrm{E}+01$ \\
\hline PBL7-3 & 7 & 3 & 98810322 & 28-Jul & Tl-208 & 50 & & $3.46 \mathrm{E}+02$ & $3.57 \mathrm{E}+01$ \\
\hline PBL8-1 & 8 & 1 & 98809886 & 28-Jul & Gross A & 1540 & $U$ & $5.00 \mathrm{E}+02$ & $4.51 E+02$ \\
\hline PBL8-1 & 8 & 1 & 98809886 & 28-Jul & Gross B & 2690 & $U$ & $-2.02 E+02$ & $7.34 \mathrm{E}+02$ \\
\hline PBL8-1 & 8 & 1 & 98809886 & 28-Jul & Ac-228 & 160 & & $1.13 E+03$ & $7.50 \mathrm{E}+01$ \\
\hline PBL8-1 & 8 & 1 & 98809886 & 28-Jul & Bi-212 & 370 & & $8.22 \mathrm{E}+02$ & $2.03 E+02$ \\
\hline PBL8-1 & 8 & 1 & 98809886 & 28-Jul & Bi-214 & 110 & & $6.54 \mathrm{E}+02$ & $5.46 \mathrm{E}+01$ \\
\hline PBL8-1 & 8 & 1 & 98809886 & 28-Jul & $\mathrm{Co}-60$ & 40 & $\mathrm{U}$ & $-9.89 E+00$ & $1.17 \mathrm{E}+01$ \\
\hline PBL8-1 & 8 & 1 & 98809886 & 28-Jul & Cs-137 & 60 & $U$ & $9.86 \mathrm{E}+00$ & $1.62 \mathrm{E}+01$ \\
\hline PBL8-1 & 8 & 1 & 98809886 & 28-Jul & $\mathrm{K}-40$ & 490 & & $9.19 \mathrm{E}+02$ & $3.15 \mathrm{E}+02$ \\
\hline PBL8-1 & 8 & 1 & 98809886 & 28-Jul & $\mathrm{Pb}-212$ & 100 & & $1.04 \mathrm{E}+03$ & $7.27 \mathrm{E}+01$ \\
\hline PBL8-1 & 8 & 1 & 98809886 & 28-Jul & $\mathrm{Pb}-214$ & 120 & & $7.16 \mathrm{E}+02$ & $6.61 E+01$ \\
\hline PBL8-1 & 8 & 1 & 98809886 & 28-Jul & Tl-208 & 50 & & $3.30 \mathrm{E}+02$ & $3.34 \mathrm{E}+01$ \\
\hline PBL8-2 & 8 & 2 & 98809887 & 28-Jul & Gross A & 1550 & & $1.70 \mathrm{E}+03$ & $6.72 \mathrm{E}+02$ \\
\hline
\end{tabular}




\begin{tabular}{|c|c|c|c|c|c|c|c|c|c|}
\hline $\begin{array}{l}\text { Sample } \\
\text { Number }\end{array}$ & $\begin{array}{c}\text { Trans. } \\
\text { ID }\end{array}$ & $\begin{array}{c}\text { Depth } \\
\text { Int. }\end{array}$ & $\underset{\mathbf{m}}{\text { Anal. Lab }}$ & Date & Analyte & $\mathrm{DL}(\mathrm{pCi} / \mathrm{kg})$ & Qual. & $\begin{array}{l}\text { Activity } \\
\text { (pCi/kg) }\end{array}$ & $\begin{array}{c} \pm 1 \text { Sigma } \\
(\mathrm{pCi} / \mathrm{kg})\end{array}$ \\
\hline PBL8-2 & 8 & 2 & 98809887 & 28-Jul & Gross B & 2690 & $\mathrm{U}$ & $7.97 \mathrm{E}+02$ & $8.05 E+02$ \\
\hline PBL8-2 & 8 & 2 & 98809887 & 28-Jul & Ac-228 & 150 & & $9.22 \mathrm{E}+02$ & $6.95 \mathrm{E}+01$ \\
\hline PBL8-2 & 8 & 2 & 98809887 & 28-Jul & $\mathrm{Bi}-212$ & 400 & & $6.08 \mathrm{E}+02$ & $1.36 \mathrm{E}+02$ \\
\hline PBL8-2 & 8 & 2 & 98809887 & 28-Jul & $\mathrm{Bi}-214$ & 90 & & $6.32 E+02$ & $5.54 \mathrm{E}+01$ \\
\hline PBL8-2 & 8 & 2 & 98809887 & 28-Jul & Co-60 & 30 & $\mathrm{U}$ & $-2.34 \mathrm{E}+00$ & $8.54 \mathrm{E}+00$ \\
\hline PBL8-2 & 8 & 2 & 98809887 & 28-Jul & Cs-137 & 50 & $U$ & $5.65 \mathrm{E}-01$ & $1.43 E+01$ \\
\hline PBL8-2 & 8 & 2 & 98809887 & 28-Jul & $\mathrm{K}-40$ & 990 & $\mathrm{U}$ & $5.19 E+02$ & $2.20 \mathrm{E}+02$ \\
\hline PBL8-2 & 8 & 2 & 98809887 & $28-\mathrm{Jul}$ & $\mathrm{Pb}-212$ & 90 & & $9.78 \mathrm{E}+02$ & $6.89 E+01$ \\
\hline PBL8-2 & 8 & 2 & 98809887 & $28-\mathrm{Jul}$ & $\mathrm{Pb}-214$ & 110 & & $7.24 \mathrm{E}+02$ & $5.97 \mathrm{E}+01$ \\
\hline PBL8-2 & 8 & 2 & 98809887 & 28-Jul & $\mathrm{Tl}-208$ & 50 & & $3.54 \mathrm{E}+02$ & $3.82 \mathrm{E}+01$ \\
\hline PBL8-3 & 8 & 3 & 98809888 & 28-Jul & Gross A & 1550 & $\mathrm{U}$ & $2.95 \mathrm{E}+02$ & $4.08 E+02$ \\
\hline PBL8-3 & 8 & 3 & 98809888 & 28-Jul & Gross B & 2700 & $\mathrm{U}$ & $3.81 E+02$ & $7.76 \mathrm{E}+02$ \\
\hline PBL8-3 & 8 & 3 & 98809888 & 28-Jul & Ac-228 & 170 & & $1.01 E+03$ & $8.68 \mathrm{E}+01$ \\
\hline PBL8-3 & 8 & 3 & 98809888 & 28-Jul & $\mathrm{Bi}-212$ & 370 & & $6.59 \mathrm{E}+02$ & $1.95 \mathrm{E}+02$ \\
\hline PBL8-3 & 8 & 3 & 98809888 & 28-Jul & Bi-214 & 100 & & $6.46 \mathrm{E}+02$ & $5.92 E+01$ \\
\hline PBL8-3 & 8 & 3 & 98809888 & 28-Jul & Co-60 & 50 & $\mathrm{U}$ & $6.22 E+00$ & $1.18 \mathrm{E}+01$ \\
\hline PBL8-3 & 8 & 3 & 98809888 & 28-Jul & Cs-137 & 60 & $\mathrm{U}$ & $1.55 \mathrm{E}+01$ & $1.69 E+01$ \\
\hline PBL8-3 & 8 & 3 & 98809888 & 28-Jul & $\mathrm{K}-40$ & 480 & & $9.22 \mathrm{E}+02$ & $2.84 \mathrm{E}+02$ \\
\hline PBL8-3 & 8 & 3 & 98809888 & 28-Jul & $\mathrm{Pb}-212$ & 100 & & $9.32 E+02$ & $6.92 \mathrm{E}+01$ \\
\hline PBL8-3 & 8 & 3 & 98809888 & 28-Jul & $\mathrm{Pb}-214$ & 120 & & $6.08 \mathrm{E}+02$ & $6.42 E+01$ \\
\hline PBL8-3 & 8 & 3 & 98809888 & 28-Jul & Tl-208 & 50 & & $2.97 \mathrm{E}+02$ & $3.26 \mathrm{E}+01$ \\
\hline PBL9-1 & 9 & 1 & 98809823 & 28-Jul & Gross A & 1640 & & $6.95 \mathrm{E}+03$ & $1.25 \mathrm{E}+03$ \\
\hline PBL9-1 & 9 & 1 & 98809823 & 28-Jul & Gross B & 2740 & $\mathrm{U}$ & $1.44 E+03$ & $8.77 E+02$ \\
\hline PBL9-1 & 9 & 1 & 98809823 & 28-Jul & Ac-228 & 140 & & $1.30 \mathrm{E}+03$ & $1.01 \mathrm{E}+02$ \\
\hline PBL9-1 & 9 & 1 & 98809823 & 28-Jul & $\mathrm{Bi}-212$ & 330 & & $7.62 E+02$ & $1.95 \mathrm{E}+02$ \\
\hline PBL9-1 & 9 & 1 & 98809823 & 28-Jul & $\mathrm{Bi}-214$ & 80 & & $9.54 \mathrm{E}+02$ & $7.45 \mathrm{E}+01$ \\
\hline PBL9-1 & 9 & 1 & 98809823 & 28-Jul & Co-60 & 50 & $\mathrm{U}$ & $1.04 E+01$ & $1.58 \mathrm{E}+01$ \\
\hline
\end{tabular}




\begin{tabular}{|c|c|c|c|c|c|c|c|c|c|}
\hline $\begin{array}{c}\text { Sample } \\
\text { Number }\end{array}$ & $\begin{array}{c}\text { Trans. } \\
\text { ID }\end{array}$ & $\begin{array}{c}\text { Depth } \\
\text { Int. }\end{array}$ & $\begin{array}{c}\text { Anal. Lab } \\
\text { ID }\end{array}$ & Date & Analyte & $\mathrm{DL}(\mathbf{p C i} / \mathbf{k g})$ & Qual. & $\begin{array}{l}\text { Activity } \\
\text { (pCi/kg) }\end{array}$ & $\begin{array}{c} \pm 1 \text { Sigma } \\
(\mathrm{pCi} / \mathrm{kg})\end{array}$ \\
\hline PBL9-1 & 9 & 1 & 98809823 & 28-Jul & Cs-137 & 50 & $\mathrm{U}$ & $2.02 \mathrm{E}+01$ & $1.76 \mathrm{E}+01$ \\
\hline PBL9-1 & 9 & 1 & 98809823 & 28-Jul & $\mathrm{K}-40$ & 350 & & $5.95 \mathrm{E}+03$ & $5.59 \mathrm{E}+02$ \\
\hline PBL9-1 & 9 & 1 & 98809823 & 28-Jul & $\mathrm{Pb}-212$ & 90 & & $1.18 \mathrm{E}+03$ & $7.92 \mathrm{E}+01$ \\
\hline PBL9-1 & 9 & 1 & 98809823 & 28-Jul & $\mathrm{Pb}-214$ & 100 & & $8.46 E+02$ & $7.14 \mathrm{E}+01$ \\
\hline PBL9-1 & 9 & 1 & 98809823 & 28-Jul & T1-208 & 50 & & $4.46 \mathrm{E}+02$ & $4.20 \mathrm{E}+01$ \\
\hline PBL10-1 & 10 & 1 & 98809817 & 27-Jul & Gross A & 1550 & U & $1.28 \mathrm{E}+03$ & $6.08 \mathrm{E}+02$ \\
\hline PBL10-1 & 10 & 1 & 98809817 & 27-Jul & Gross B & 2690 & $\mathrm{U}$ & $2.92 \mathrm{E}+02$ & $7.73 E+02$ \\
\hline PBL10-1 & 10 & 1 & 98809817 & 27-Jul & Ac-228 & 140 & & $8.78 \mathrm{E}+02$ & $7.76 \mathrm{E}+01$ \\
\hline PBL10-1 & 10 & 1 & 98809817 & 27-Jul & $\mathrm{Bi}-212$ & 330 & & $3.46 \mathrm{E}+02$ & $1.20 \mathrm{E}+02$ \\
\hline PBL10-1 & 10 & 1 & 98809817 & 27-Jul & $\mathrm{Bi}-214$ & 80 & & $6.00 \mathrm{E}+02$ & $5.24 \mathrm{E}+01$ \\
\hline PBL10-1 & 10 & 1 & 98809817 & 27-Jul & Co- 60 & 40 & $\mathrm{U}$ & $1.39 \mathrm{E}+01$ & $1.08 \mathrm{E}+01$ \\
\hline PBL10-1 & 10 & 1 & 98809817 & 27-Jul & Cs- 137 & 50 & $\mathrm{U}$ & $8.19 \mathrm{E}+00$ & $1.36 \mathrm{E}+01$ \\
\hline PBL10-1 & 10 & 1 & 98809817 & 27-Jul & $\mathrm{K}-40$ & 310 & & $5.57 \mathrm{E}+02$ & $2.30 \mathrm{E}+02$ \\
\hline PBL10-1 & 10 & 1 & 98809817 & 27-Jul & $\mathrm{Pb}-212$ & 90 & & $6.70 \mathrm{E}+02$ & $5.42 \mathrm{E}+01$ \\
\hline PBL10-1 & 10 & 1 & 98809817 & 27-Jul & $\mathrm{Pb}-214$ & 100 & & $5.65 \mathrm{E}+02$ & $5.27 \mathrm{E}+01$ \\
\hline PBL10-1 & 10 & 1 & 98809817 & 27-Jul & Tl-208 & 50 & & $2.28 \mathrm{E}+02$ & $2.82 E+01$ \\
\hline PBL10-2 & 10 & 2 & 98809818 & 27-Jul & Gross A & 1530 & $\mathrm{U}$ & $1.11 \mathrm{E}+03$ & $5.55 \mathrm{E}+02$ \\
\hline PBL10-2 & 10 & 2 & 98809818 & 27-Jul & Gross B & $2670^{\circ}$ & $U$ & $-1.59 \mathrm{E}+02$ & $7.30 \mathrm{E}+02$ \\
\hline PBL10-2 & 10 & 2 & 98809818 & 27-Jul & Ac-228 & 140 & & $9.38 \mathrm{E}+02$ & $7.93 E+01$ \\
\hline PBL10-2 & 10 & 2 & 98809818 & 27-Jul & $\mathrm{Bi}-212$ & 370 & & $6.92 \mathrm{E}+02$ & $1.95 \mathrm{E}+02$ \\
\hline PBL10-2 & 10 & 2 & 98809818 & 27-Jul & $\mathrm{Bi}-214$ & 90 & & $5.51 \mathrm{E}+02$ & $5.58 \mathrm{E}+01$ \\
\hline PBL10-2 & 10 & 2 & 98809818 & 27-Jul & Co-60 & 50 & $\mathrm{U}^{\circ}$ & $1.15 E+01$ & $1.24 \mathrm{E}+01$ \\
\hline PBL10-2 & 10 & 2 & 98809818 & 27-Jul & Cs- 137 & 40 & $\mathrm{U}$ & $2.29 \mathrm{E}+01$ & $1.49 \mathrm{E}+01$ \\
\hline PBL10-2 & 10 & 2 & 98809818 & 27-JuI & $\mathrm{K}-40$ & 410 & & $8.46 E+02$ & $2.86 \mathrm{E}+02$ \\
\hline PBL10-2 & 10 & 2 & 98809818 & 27-Jul & $\mathrm{Pb}-212$ & 80 & & $9.57 \mathrm{E}+02$ & $6.93 E+01$ \\
\hline PBL10-2 & 10 & 2 & 98809818 & 27-Jul & $\mathrm{Pb}-214$ & 110 & & $5.30 \mathrm{E}+02$ & $5.45 \mathrm{E}+01$ \\
\hline PBL10-2 & 10 & 2 & 98809818 & 27-Jul & Tl-208 & 50 & & $3.16 \mathrm{E}+02$ & $3.04 E+01$ \\
\hline
\end{tabular}




\begin{tabular}{|c|c|c|c|c|c|c|c|c|c|}
\hline $\begin{array}{l}\text { Sample } \\
\text { Number }\end{array}$ & $\begin{array}{c}\text { Trans. } \\
\text { ID }\end{array}$ & $\begin{array}{c}\text { Depth } \\
\text { Int. }\end{array}$ & $\begin{array}{c}\text { Anal. Lab } \\
\text { ID }\end{array}$ & Date & Analyte & $\mathrm{DL}(\mathrm{pCi} / \mathrm{kg})$ & Qual. & $\begin{array}{l}\text { Activity } \\
\text { (pCi/kg) }\end{array}$ & $\begin{array}{c} \pm 1 \text { Sigma } \\
(\mathrm{pCi} / \mathrm{kg})\end{array}$ \\
\hline PBL10-3 & 10 & 3 & 98809819 & 27-Jul & Gross A & 1810 & $\mathrm{U}$ & $5.05 E+02$ & $5.01 E+02$ \\
\hline PBL10-3 & 10 & 3 & 98809819 & 27-Jul & Gross B & 3210 & $\mathrm{U}$ & $2.92 E+02$ & $9.20 \mathrm{E}+02$ \\
\hline PBL10-3 & 10 & 3 & 98809819 & 27-Jul & Ac-228 & 160 & & $1.01 \mathrm{E}+03$ & $7.88 \mathrm{E}+01$ \\
\hline PBL10-3 & 10 & 3 & 98809819 & 27-Jul & $\mathrm{Bi}-212$ & 380 & & $7.11 \mathrm{E}+02$ & $1.86 \mathrm{E}+02$ \\
\hline PBL10-3 & 10 & 3 & 98809819 & 27-JuI & Bi-214 & 90 & & $5.97 \mathrm{E}+02$ & $5.84 \mathrm{E}+01$ \\
\hline PBL10-3 & 10. & 3 & 98809819 & 27-Jul & Co-60 & 40 & $U$ & $-6.68 E+00$ & $1.20 \mathrm{E}+01$ \\
\hline PBL10-3 & 10 & 3 & 98809819 & 27-Jul & Cs- 137 & 50 & $\mathrm{U}$ & $-3.22 E+00$ & $1.41 E+01$ \\
\hline PBL10-3 & 10 & 3 & 98809819 & 27-Jul & $\mathrm{K}-40$ & 1070 & $\mathrm{U}$ & $5.14 \mathrm{E}+02$ & $2.43 E+02$ \\
\hline PBL10-3 & 10 & 3 & 98809819 & 27-Jul & $\mathrm{Pb}-212$ & 90 & & $8.92 \mathrm{E}+02$ & $6.99 E+01$ \\
\hline PBL10-3 & 10 & 3 & 98809819 & 27-Jul & $\mathrm{Pb}-214$ & 110 & & $6.73 E+02$ & $7.15 E+01$ \\
\hline PBL10-3 & 10 & 3 & 98809819 & 27-Jul & $\mathrm{Tl}-208$ & 50 & & $3.05 E+02$ & $3.70 \mathrm{E}+01$ \\
\hline PBL11-1 & 11 & 1 & 98809796 & 27-Jul & Gross A & 1830 & $\mathrm{U}$ & $9.41 E+02$ & $5.80 \mathrm{E}+02$ \\
\hline PBL11-1 & 11 & 1 & 98809796 & 27-Jul & Gross B & 3230 & $\mathrm{U}$ & $4.27 \mathrm{E}+01$ & $9.09 E+02$ \\
\hline PBL11-1 & 11 & 1 & 98809796 & 27-Jul & Ac-228 & 160 & & $8.51 E+02$ & $8.42 \mathrm{E}+01$ \\
\hline PBL11-1 & 11 & 1 & 98809796 & 27-Jul & $\mathrm{Bi}-212$ & 420 & & $7.08 \mathrm{E}+02$ & $1.51 \mathrm{E}+02$ \\
\hline PBL1 1-1 & 11 & 1 & 98809796 & 27-Jul & $\mathrm{Bi}-214$ & 80 & & $6.51 E+02$ & $6.01 E+01$ \\
\hline PBL11-1 & 11 & 1 & 98809796 & 27-Jul & Co-60 & 40 & $\mathrm{U}$ & $-4.57 \mathrm{E}+00$ & $1.35 \mathrm{E}+01$ \\
\hline PBL11-1 & 11 & 1 & 98809796 & 27-Jul & Cs-137 & 60 & & $9.65 E+01$ & $1.84 \mathrm{E}+01$ \\
\hline PBL11-1 & 11 & 1 & 98809796 & 27-Jul & $\mathrm{K}-40$ & 470 & & $5.19 \mathrm{E}+02$ & $2.28 \mathrm{E}+02$ \\
\hline PBL11-1 & 11 & 1 & 98809796 & 27-Jul & $\mathrm{Pb}-212$ & .90 & & $8.57 \mathrm{E}+02$ & $6.20 \mathrm{E}+01$ \\
\hline PBL11-1 & 11 & 1 & 98809796 & 27-Jul & $\mathrm{Pb}-214$ & 110 & & $5.49 \mathrm{E}+02$ & $5.76 E+01$ \\
\hline PBL'11-1 & 11 & 1 & 98809796 & 27-Jul & Tl-208 & 50 & & $2.86 \mathrm{E}+02$ & $3.34 E+01$ \\
\hline PBL11-1B & 11 & 1 & 98809799 & 27-Jul & Gross A & 1830 & & $2.44 E+03$ & $8.20 \mathrm{E}+02$ \\
\hline PBL11-1B & 11 & 1 & 98809799 & 27-Jul & Gross B & 3240 & $\mathrm{U}$ & $-1.16 \mathrm{E}+03$ & $8.39 E+02$ \\
\hline PBL11-1B & 11 & 1 & 98809799 & 27-Jul & Ac-228 & 160 & & $1.11 E+03$ & $8.35 \mathrm{E}+01$ \\
\hline PBL1 1-1B & 11 & 1 & 98809799 & 27-Jul & $\mathrm{Bi}-212$ & 360 & & $6.14 E+02$ & $1.74 E+02$ \\
\hline PBLI1-1B & 11 & 1 & 98809799 & 27-Jul & Bi-214 & 90 & & $6.84 \mathrm{E}+02$ & $5.77 \mathrm{E}+01$ \\
\hline
\end{tabular}




\begin{tabular}{|c|c|c|c|c|c|c|c|c|c|}
\hline $\begin{array}{c}\text { Sample } \\
\text { Number }\end{array}$ & $\begin{array}{c}\text { Trans. } \\
\text { ID }\end{array}$ & $\begin{array}{c}\text { Depth } \\
\text { Int. }\end{array}$ & $\begin{array}{c}\text { Anal. Lab } \\
\mathbf{m}\end{array}$ & Date & Analyte & $\mathrm{DL}(\mathrm{pCi} / \mathrm{kg})$ & Qual. & $\begin{array}{l}\text { Activity } \\
(\mathrm{pCi} / \mathrm{kg})\end{array}$ & $\begin{array}{c} \pm 1 \text { Sigma } \\
(\mathrm{pCi} / \mathrm{kg})\end{array}$ \\
\hline PBL11-1B & 11 & 1 & 98809799 & 27-Jul & Co-60 & 50 & $\mathrm{U}$ & $6.81 E+00$ & $1.28 \mathrm{E}+01$ \\
\hline PBL11-1B & 11 & 1 & 98809799 & 27-Jul & Cs- 137 & 50 & & $9.00 \mathrm{E}+01$ & $2.31 E+01$ \\
\hline PBL11-1B & 11 & 1 & 98809799 & 27-Jul & $\mathrm{K}-40$ & 270 & & $6.05 \mathrm{E}+02$ & $2.35 \mathrm{E}+02$ \\
\hline PBL11-1B & 11 & 1 & 98809799 & 27-Jul & $\mathrm{Pb}-212$ & 100 & & $8.51 E+02$ & $6.55 \mathrm{E}+01$ \\
\hline PBL11-1B & 11 & 1 & 98809799 & 27-Jul & $\mathrm{Pb}-214$ & 110 & & $5.81 E+02$ & $5.68 \mathrm{E}+01$ \\
\hline PBL11-1B & 11 & 1 & 98809799 & 27-Jul & $\mathrm{Tl}-208$ & 50 & & $2.51 E+02$ & $3.57 \mathrm{E}+01$ \\
\hline PBL11-2 & 11 & 2 & 98809800 & 27-Jul & Gross A & 1820 & $\mathrm{U}$ & $1.38 \mathrm{E}+03$ & $6.51 E+02$ \\
\hline PBL1 1-2 & 11 & 2 & 98809800 & 27-Jul & Gross B & 3220 & $\mathrm{U}$ & $-2.09 E+02$ & $8.89 E+02$ \\
\hline PBLI1-2 & 11 & 2 & 98809800 & 27-Jul & Ac-228 & 140 & & $9.73 E+02$ & $8.96 E+01$ \\
\hline PBL11-2 & 11 & 2 & 98809800 & 27-Jul & $\mathrm{Bi}-212$ & 310 & & $8.11 E+02$ & $1.74 \mathrm{E}+02$ \\
\hline PBL11-2 & 11 & 2 & 98809800 & 27-Jul & $\mathrm{Bi}-214$ & 90 & & $6.78 \mathrm{E}+02$ & $6.05 E+01$ \\
\hline PBL11-2 & 11 & 2 & 98809800 & 27-Jul & Co-60 & 40 & $\mathrm{U}$ & $1.49 \mathrm{E}+01$ & $1.38 \mathrm{E}+01$ \\
\hline PBL11-2 & 11 & 2 & 98809800 & $27-\mathrm{Jul}$ & Cs- 137 & 50 & $\mathrm{U}$ & $1.85 \mathrm{E}+01$ & $1.47 \mathrm{E}+01$ \\
\hline PBL11-2 & 11 & 2 & 98809800 & 27-Jul & $\mathrm{K}-40$ & 300 & & $6.05 E+02$ & $2.65 \mathrm{E}+02$ \\
\hline PBL11-2 & 11 & 2 & 98809800 & 27-Jul & $\mathrm{Pb}-212$ & 80 & & $8.78 E+02$ & $6.58 \mathrm{E}+01$ \\
\hline PBL11-2 & 11 & 2 & 98809800 & 27-Jul & $\mathrm{Pb}-214$ & 100 & & $7.35 \mathrm{E}+02$ & $5.86 \mathrm{E}+01$ \\
\hline PBL11-2 & 11 & 2 & 98809800 & 27-Jul & TI-208 & 40 & & $3.70 \mathrm{E}+02$ & $3.27 \mathrm{E}+01$ \\
\hline PBL11-3 & 11 & 3 & 98809801 & 27-Jul & Gross A & 1810 & $\mathrm{U}$ & $3.89 \mathrm{E}+02$ & $3.36 \mathrm{E}+02$ \\
\hline PBL11-3 & 11 & 3 & 98809801 & 27-Jul & Gross B & 3220 & $\mathrm{U}$ & $1.79 \mathrm{E}+02$ & $6.41 \mathrm{E}+02$ \\
\hline PBL1 1-3 & 11 & 3 & 98809801 & 27-Jul & Ac-228 & 140 & & $7.41 \mathrm{E}+02$ & $7.26 E+01$ \\
\hline PBL1 1-3 & 11 & 3 & 98809801 & 27-Jul & $\mathrm{Bi}-212$ & 320 & & $7.43 E+02$ & $1.64 \mathrm{E}+02$ \\
\hline PBL11-3 & 11 & 3 & 98809801 & 27-Jul & $\mathrm{Bi}-214$ & 70 & & $5.68 \mathrm{E}+02$ & $4.45 E+01$ \\
\hline PBL11-3 & 11 & 3 & 98809801 & 27-Jul & Co-60 & 40 & U & $-7.70 \mathrm{E}+00$ & $1.19 E+01$ \\
\hline PBL1 1-3 & 11 & 3 & 98809801 & 27-Jul & Cs-137 & 50 & U & $1.78 \mathrm{E}+01$ & $1.29 \mathrm{E}+01$ \\
\hline PBL1 1-3 & 11 & 3 & 98809801 & 27-Jul & $\mathrm{K}-40$ & 770 & $\mathrm{U}$ & $-1.22 \mathrm{E}+02$ & $1.77 \mathrm{E}+02$ \\
\hline PBL11-3 & 11 & 3 & 98809801 & 27-Jul & $\mathrm{Pb}-212$ & 90 & & $7.84 \mathrm{E}+02$ & $5.93 E+01$ \\
\hline PBL1 1-3 & 11 & 3 & 98809801 & 27-Jul & $\mathrm{Pb}-214$ & 100 & & $5.84 \mathrm{E}+02$ & $6.20 \mathrm{E}+01$ \\
\hline
\end{tabular}




\begin{tabular}{|c|c|c|c|c|c|c|c|c|c|}
\hline $\begin{array}{l}\text { Sample } \\
\text { Number }\end{array}$ & $\begin{array}{c}\text { Trans. } \\
\text { ID }\end{array}$ & $\begin{array}{l}\text { Depth } \\
\text { Int. }\end{array}$ & $\begin{array}{c}\text { Anal. Lab } \\
\text { ID }\end{array}$ & Date & Analyte & $\mathrm{DL}(\mathrm{pCi} / \mathrm{kg})$ & Qual. & $\begin{array}{l}\text { Activity } \\
\text { (pCi/kg) }\end{array}$ & $\begin{array}{c} \pm 1 \text { Sigma } \\
(\mathrm{pCi} / \mathrm{kg})\end{array}$ \\
\hline PBL11-3 & 11 & 3 & 98809801 & 27-Jul & Tl-208 & 60 & & $2.89 \mathrm{E}+02$ & $3.27 \mathrm{E}+01$ \\
\hline PBL12-1 & 12 & 1 & 98809790 & 27-Jul & Gross A & 1680 & & $1.78 \mathrm{E}+03$ & $7.22 \mathrm{E}+02$ \\
\hline PBL12-1 & 12 & 1 & 98809790 & 27-Jul & Gross B & 2720 & $\mathbf{U}$ & $2.36 \mathrm{E}+03$ & $8.92 E+02$ \\
\hline PBL12-1 & 12 & 1 & 98809790 & 27-Jul & Ac-228 & 170 & & $2.64 \mathrm{E}+03$ & $1.11 \mathrm{E}+02$ \\
\hline PBL12-1 & 12 & 1 & 98809790 & 27-Jul & $\mathrm{Bi}-212$ & 490 & & $1: 78 \mathrm{E}+03$ & $2.82 E+02$ \\
\hline PBL12-1 & 12 & 1 & 98809790 & 27-Jul & $\mathrm{Bi}-214$ & 130 & & $1.53 \mathrm{E}+03$ & $9.23 E+01$ \\
\hline PBL12-1 & 12 & 1 & 98809790 & 27-Jul & $\mathrm{Co}-60$ & 60 & $\mathrm{U}$ & $8.19 \mathrm{E}-01$ & $1.54 \mathrm{E}+01$ \\
\hline PBL12-1 & 12 & 1 & 98809790 & 27-Jul & Cs-137 & 70 & & $9.73 E+01$ & $2.82 E+01$ \\
\hline PBL12-1 & 12 & 1 & 98809790 & 27-Jul & $\mathrm{K}-40$ & 500 & & $1.71 E+03$ & $3.24 \mathrm{E}+02$ \\
\hline PBL12-1 & 12 & 1 & 98809790 & 27-Jul & $\mathrm{Pb}-212$ & 150 & & $2.06 \mathrm{E}+03$ & $1.20 \mathrm{E}+02$ \\
\hline PBL12-1 & 12 & 1 & 98809790 & 27-Jul & $\mathrm{Pb}-214$ & 130 & & $1.58 \mathrm{E}+03$ & $1.01 E+02$ \\
\hline PBL12-1 & 12 & 1 & 98809790 & 27-Jul & Tl-208 & 70 & & $9.03 E+02$ & $6.22 \mathrm{E}+01$ \\
\hline PBL12-2 & 12 & 2 & 98809794 & 27-Jul & Gross A & 1500 & & $2.01 E+03$ & $6.93 E+02$ \\
\hline PBL12-2 & 12 & 2 & 98809794 & 27-Jul & Gross B & 2470 & $\mathrm{U}$ & $1.15 E+03$ & $7.57 \mathrm{E}+02$ \\
\hline PBL12-2 & 12 & 2 & 98809794 & 27-Jul & Ac-228 & 200 & & $2.76 \mathrm{E}+03$ & $1.58 \mathrm{E}+02$ \\
\hline PBL12-2 & 12 & 2 & 98809794 & 27-Jul & $\mathrm{Bi}-212$ & 460 & & $2.46 \mathrm{E}+03$ & $3.26 \mathrm{E}+02$ \\
\hline PBL 12-2 & 12 & 2 & 98809794 & 27-Jul & $\mathrm{Bi}-214$ & 130 & & $1.74 E+03$ & $9.70 \mathrm{E}+01$ \\
\hline PBL12-2 & 12 & 2 & 98809794 & 27-Jul & Co-60 & 70 & $\mathrm{U}$ & $-3.62 E-01$ & $1.80 \mathrm{E}+01$ \\
\hline PBL12-2 & 12 & 2 & 98809794 & 27-Jul & Cs-137 & 70 & $\mathrm{U}$ & $-1.37 E+01$ & $2.04 \mathrm{E}+01$ \\
\hline PBL12-2 & 12 & 2 & 98809794 & 27-Jul & $\mathrm{K}-40$ & 730 & & $1.16 \mathrm{E}+03$ & $3.51 E+02$ \\
\hline PBL12-2 & 12 & 2 & 98809794 & 27-Jul & $\mathrm{Pb}-212$ & 140 & & $2.62 E+03$ & $1.49 E+02$ \\
\hline PBL12-2 & 12 & 2 & 98809794 & 27-Jul & $\mathrm{Pb}-214$ & 150 & & $1.77 \mathrm{E}+03$ & $1.12 \mathrm{E}+02$ \\
\hline PBL12-2 & 12 & 2 & 98809794 & 27-Jul & Tl-208 & 70 & & $9.38 E+02$ & $6.78 E+01$ \\
\hline PBL13-1 & 13 & 1 & 98809784 & 27-Jul & Gross A & 1400 & U & $1.00 \mathrm{E}+03$ & $5.22 \mathrm{E}+02$ \\
\hline PBL13-1 & 13 & 1 & 98809784 & 27-Jul & Gross B & 2420 & U & $1.09 E+02$ & $6.74 \mathrm{E}+02$ \\
\hline PBL13-1 & 13 & 1 & 98809784 & 27-Jul & Ac-228 & 130 & & $9.05 E+02$ & $8.11 E+01$ \\
\hline PBL13-1 & 13 & 1 & 98809784 & 27-Jul & Bi-212 & 330 & & $9.30 E+02$ & $1.92 \mathrm{E}+02$ \\
\hline
\end{tabular}




\begin{tabular}{|c|c|c|c|c|c|c|c|c|c|}
\hline $\begin{array}{l}\text { Sample } \\
\text { Number }\end{array}$ & $\begin{array}{c}\text { Trans. } \\
\text { ID }\end{array}$ & $\begin{array}{c}\text { Depth } \\
\text { Int. }\end{array}$ & $\begin{array}{c}\text { Anal. Lab } \\
\text { ID }\end{array}$ & Date & Analyte & $\mathrm{DL}(\mathrm{pCi} / \mathrm{kg})$ & Qual. & $\begin{array}{l}\text { Activity } \\
\text { (pCi/kg) }\end{array}$ & $\begin{array}{c} \pm 1 \text { Sigma } \\
(\mathrm{pCi} / \mathrm{kg})\end{array}$ \\
\hline PBL13-1 & 13 & 1 & 98809784 & 27-Jul $\mathrm{F}$ & $\mathrm{Bi}-214$ & 100 & & $6.78 \mathrm{E}+02$ & $4.96 \mathrm{E}+01$ \\
\hline PBL13-1 & 13 & 1 & 98809784 & 27-Jul C & Co- 60 & 40 & $\mathrm{U}$ & $1.22 \mathrm{E}+00$ & $1.11 E+01$ \\
\hline PBL13-1 & 13 & 1 & 98809784 & 27-Jul C & Cs-137 & 50 & & $1.43 \mathrm{E}+02$ & $2.89 \mathrm{E}+01$ \\
\hline PBL13-1 & 13 & 1 & 98809784 & 27-Jul & $\mathrm{K}-40$ & 350 & & $1.10 \mathrm{E}+03$ & $2.85 E+02$ \\
\hline PBL13-1 & 13 & 1 & 98809784 & 27-Jul & $\mathrm{Pb}-212$ & 90 & & $9.22 \mathrm{E}+02$ & $6.54 \mathrm{E}+01$ \\
\hline PBL13-1 & 13 & 1 & 98809784 & 27-Jul & $\mathrm{Pb}-214$ & 100 & & $7.81 \mathrm{E}+02$ & $6.14 \mathrm{E}+01$ \\
\hline PBL13-1 & 13 & 1 & 98809784 & 27-Jul & Tl-208 & 50 & & $3.38 E+02$ & $3.39 E+01$ \\
\hline PBL13-2 & 13 & 2 & 98809785 & 27-Jul & Gross A & 1800 & & $2.73 E+03$ & $8.58 \mathrm{E}+02$ \\
\hline PBL13-2 & 13 & 2 & 98809785 & 27-Jul & Gross B & 2720 & $\mathrm{U}$ & $1.61 \mathrm{E}+03$ & $8.58 \mathrm{E}+02$ \\
\hline PBL13-2 & 13 & 2 & 98809785 & 27-Jul & Ac-228 & 160 & & $1.17 \mathrm{E}+03$ & $9.08 \mathrm{E}+01$ \\
\hline PBLI3-2 & 13 & 2 & 98809785 & 27-Jul & $\mathrm{Bi}-212$ & 380 & & $8.35 E+02$ & $2.24 E+02$ \\
\hline PBL13-2 & 13 & 2 & 98809785 & 27-Jul & $\mathrm{Bi}-214$ & 100 & & $7.16 \mathrm{E}+02$ & $5.97 \mathrm{E}+01$ \\
\hline PBL13-2 & 13 & 2 & 98809785 & 27-Jul & Co-60 & 30 & $\mathrm{U}$ & $-2.60 E+01$ & $1.12 \mathrm{E}+01$ \\
\hline PBL13-2 & 13 & 2 & 98809785 & 27-Jul & Cs-137 & 60 & $\mathrm{U}$ & $1.26 \mathrm{E}+01$ & $1.54 \mathrm{E}+01$ \\
\hline PBL13-2 & 13 & 2 & 98809785 & 27-Jul & $\mathrm{K}-40$ & 540 & & $1.14 \mathrm{E}+03$ & $3.50 \mathrm{E}+02$ \\
\hline PBL13-2 & 13 & 2 & 98809785 & 27-Jul & $\mathrm{Pb}-212$ & 100 & & $1.03 E+03$ & $7.32 \mathrm{E}+01$ \\
\hline PBL13-2 & 13 & 2 & 98809785 & 27-Jul & $\mathrm{Pb}-214$ & 100 & & $7.51 \mathrm{E}+02$ & $6.28 \mathrm{E}+01$ \\
\hline PBL13-2 & 13 & 2 & 98809785 & 27-Jul & $\mathrm{Ra}-224$ & 1140 & & $1.82 \mathrm{E}+03$ & $5.58 \mathrm{E}+02$ \\
\hline PBL13-2 & 13 & 2 & 98809785 & 27-Jul & Tl-208 & 50 & & $3.78 \mathrm{E}+02$ & $4.14 \mathrm{E}+01$ \\
\hline PBL13-3 & 13 & 3 & 98809786 & 27-Jul & Gross A & 1590 & & $5.24 \mathrm{E}+03$ & $1.10 \mathrm{E}+03$ \\
\hline PBL13-3 & 13 & 3 & 98809786 & 27-Jul & Gross B & 2500 & $\mathrm{U}$ & $1.43 E+03$ & $7.99 \mathrm{E}+02$ \\
\hline PBL13-3 & 13 & 3 & 98809786 & 27-Jul & Ac-228 & 170 & & $1.62 E+03$ & $1.08 \mathrm{E}+02$ \\
\hline PBL13-3 & 13 & 3 & 98809786 & 27-Jul & $\mathrm{Bi}-212$ & 400 & & $1.26 E+03$ & $2.31 \mathrm{E}+02$ \\
\hline PBL13-3 & 13 & 3 & 98809786 & 27-Jul & $\mathrm{Bi}-214$ & 110 & & $9.43 E+02$ & $6.91 \mathrm{E}+01$ \\
\hline PBL13-3 & 13 & 3 & 98809786 & 27-Jul & Co-60 & 60 & $\mathrm{U}$ & $1.91 E+01$ & $1.42 \mathrm{E}+01$ \\
\hline PBL13-3 & 13 & 3 & 98809786 & 27-Jul & Cs-137 & 70 & $\mathrm{U}$ & $1.23 \mathrm{E}+01$ & $1.85 E+01$ \\
\hline PBL13-3 & 13 & 3 & 98809786 & 27-Jul & $\mathrm{K}-40$ & 490 & & $1.26 \mathrm{E}+03$ & $2.93 E+02$ \\
\hline
\end{tabular}




\begin{tabular}{|c|c|c|c|c|c|c|c|c|c|}
\hline $\begin{array}{c}\text { Sample } \\
\text { Number }\end{array}$ & $\underset{\text { ID }}{\text { Trans. }}$ & $\begin{array}{c}\text { Depth } \\
\text { Int. }\end{array}$ & $\begin{array}{c}\text { Anal. Lab } \\
\text { ID }\end{array}$ & Date & Analyte & $\mathrm{DL}(\mathrm{pCi} / \mathrm{kg})$ & Qual. & $\begin{array}{l}\text { Activity } \\
\text { (pCi/kg) }\end{array}$ & $\begin{array}{c} \pm 1 \text { Sigma } \\
(\mathrm{pCi} / \mathrm{kg})\end{array}$ \\
\hline PBĹ13-3 & 13 & 3 & 98809786 & 27-Jul & $\mathrm{Pb}-212$ & 120 & & $1.21 E+03$ & $8.91 E+01$ \\
\hline PBLL13-3 & 13 & 3 & 98809786 & 27-Jul & $\mathrm{Pb}-214$ & 120 & & $8.57 \mathrm{E}+02$ & $7.38 \mathrm{E}+01$ \\
\hline PBL13-3 & 13 & 3 & 98809786 & 27-Jul & Tl-208 & 60 & & $4.92 \mathrm{E}+02$ & $4.49 \mathrm{E}+01$ \\
\hline PBL14-1 & 14 & 1 & 98809772 & 27-Jul & Gross A & 1510 & $\mathrm{U}$ & $3.59 \mathrm{E}+02$ & $2.93 \mathrm{E}+02$ \\
\hline PBL14-1 & 14 & 1 & 98809772 & 27-Jul & Gross B & 2600 & $\mathrm{U}$ & $9.59 \mathrm{E}+02$ & $5.46 \mathrm{E}+02$ \\
\hline PBL14-1 & 14 & 1 & 98809772 & 27-Jul & Ac-228 & 130 & & $9.38 \mathrm{E}+02$ & $6.78 \mathrm{E}+01$ \\
\hline PBL14-1 & 14 & 1 & 98809772 & 27-Jul & $\mathrm{Bi}-212$ & 310 & & $7.38 \mathrm{E}+02$ & $1.77 \mathrm{E}+02$ \\
\hline PBL14-1 & 14 & 1 & 98809772 & 27-Jul & $\mathrm{Bi}-214$ & 80 & & $5.89 \mathrm{E}+02$ & $5.28 \mathrm{E}+01$ \\
\hline PBL14-1 & 14 & 1 & 98809772 & 27-Jul & Co-60 & 40 & $U$ & $-1.72 E+00$ & $1.12 \mathrm{E}+01$ \\
\hline PBL14-1 & 14 & 1 & 98809772 & 27-Jul & Cs-137 & 40 & & $1.17 \mathrm{E}+02$ & $3.03 E+01$ \\
\hline PBL14-1 & 14 & 1 & 98809772 & 27-Jul & $\mathrm{K}-40$ & 350 & & $6.76 \mathrm{E}+02$ & $2.14 \mathrm{E}+02$ \\
\hline PBL14-1 & 14 & 1 & 98809772 & 27-Jul & $\mathrm{Pb}-212$ & 90 & & $8.65 E+02$ & $6.31 \mathrm{E}+01$ \\
\hline PBL14-1 & 14 & 1 & 98809772 & 27-Jul & $\mathrm{Pb}-214$ & 100 & & $6.35 E+02$ & $5.39 \mathrm{E}+01$ \\
\hline PBL14-1 & 14 & 1 & 98809772 & 27-Jul & T1-208 & 40 & & $2.81 E+02$ & $2.82 E+01$ \\
\hline PBL14-2 & 14 & 2 & 98809773 & 27-Jul & Gross A & 1560 & $\mathrm{U}$ & $8.51 E+02$ & $5.26 E+02$ \\
\hline PBL14-2 & 14 & 2 & 98809773 & 27-Jul & Gross B & 2620 & $\mathrm{U}$ & $1.40 \mathrm{E}+03$ & $8.08 \mathrm{E}+02$ \\
\hline PBL14-2 & 14 & 2 & 98809773 & 27-Jul & Ac-228 & 170 & & $9.35 E+02$ & $8.31 \mathrm{E}+01$ \\
\hline PBL14-2 & 14 & 2 & 98809773 & 27-Jul & $\mathrm{Bi}-214$ & 90 & & $5.62 E+02$ & $5.54 \mathrm{E}+01$ \\
\hline PBL14-2 & 14. & 2 & 98809773 & 27-Jul & Co-60 & 50 & $\mathrm{U}$ & $4.81 E+00$ & $1.18 \mathrm{E}+01$ \\
\hline PBL14-2 & 14 & 2 & 98809773 & 27-Jul & Cs-137 & 60 & U & $6.92 \mathrm{E}+00$ & $1.50 \mathrm{E}+01$ \\
\hline PBL14-2 & 14 & 2 & 98809773 & 27-Jul & $\mathrm{K}-40$ & 430 & & $8.92 \mathrm{E}+02$ & $2.41 E+02$ \\
\hline PBL14-2 & 14 & 2 & 98809773 & 27-Jul & $\mathrm{Pb}-212$ & 100 & & $7.59 \mathrm{E}+02$ & $6.11 E+01$ \\
\hline PBL14-2 & 14 & 2 & 98809773 & 27-Jul & $\mathrm{Pb}-214$ & 100 & & $6.19 E+02$ & $6.09 \mathrm{E}+01$ \\
\hline PBL14-2 & 14 & 2 & 98809773 & 27-Jul & T1-208 & 50 & & $2.84 E+02$ & $3.45 E+01$ \\
\hline PBL 14-3 & 14 & 3 & 98809774 & 27-Jul & Gross A & 1670 & & $3.11 \mathrm{E}+03$ & $8.68 \mathrm{E}+02$ \\
\hline PBL 14-3 & 14 & 3 & 98809774 & 27-Jul & Gross B & 2660 & $\mathrm{U}$ & $1.91 E+03$ & $8.68 \mathrm{E}+02$ \\
\hline PBLI4-3 & 14 & 3 & 98809774 & 27-Jul & Ac-228 & 180 & & $1.06 \mathrm{E}+03$ & $9.31 \mathrm{E}+01$ \\
\hline
\end{tabular}




\begin{tabular}{|c|c|c|c|c|c|c|c|c|c|}
\hline $\begin{array}{c}\text { Sample } \\
\text { Number }\end{array}$ & $\begin{array}{c}\text { Trans. } \\
\text { ID }\end{array}$ & $\begin{array}{l}\text { Depth } \\
\text { Int. }\end{array}$ & $\underset{\text { ID }}{\text { Anal. Lab }}$ & Date & Analyte & $\mathrm{DL}(\mathrm{pCi} / \mathrm{kg})$ & Qual. & $\begin{array}{l}\text { Activity } \\
\text { (pCi/kg) }\end{array}$ & $\begin{array}{c} \pm 1 \text { Sigma } \\
(\mathrm{pCi} / \mathrm{kg})\end{array}$ \\
\hline PBL14-3 & 14 & 3 & 98809774 & 27-Jul & $\mathrm{Bi}-212$ & 400 & & $9.16 \mathrm{E}+02$ & $2.08 \mathrm{E}+02$ \\
\hline PBL14-3 & 14 & 3 & 98809774 & 27-Jul & $\mathrm{Bi}-214$ & 100 & & $6.00 \mathrm{E}+02$ & $5.91 \mathrm{E}+01$ \\
\hline PBL14-3 & 14 & 3 & 98809774 & 27-Jul & Co-60 & 60 & $\mathrm{U}$ & $-4.54 \mathrm{E}+00$ & $1.65 \mathrm{E}+01$ \\
\hline PBL14-3 & 14 & 3 & 98809774 & 27-Jul & Cs-137 & $\cdot 60$ & $\mathrm{U}$ & $-1.65 E+01$ & $1.65 \mathrm{E}+01$ \\
\hline PBL14-3 & 14 & 3 & 98809774 & 27-Jul & $\mathrm{K}-40$ & 1180 & $\mathrm{U}$ & $6.30 \mathrm{E}+02$ & $2.70 \mathrm{E}+02$ \\
\hline PBL14-3 & 14 & 3 & 98809774 & 27-Jul & $\mathrm{Pb}-212$ & 120 & & $8.68 \mathrm{E}+02$ & $8.30 \mathrm{E}+01$ \\
\hline PBL14-3 & 14 & 3 & 98809774 & 27-Jul & $\mathrm{Pb}-214$ & 110 & & $6.08 \mathrm{E}+02$ & $6.08 \mathrm{E}+01$ \\
\hline PBL14-3 & 14 & 3 & 98809774 & 27-Jul & Tl-208 & 60 & & $3.51 \mathrm{E}+02$ & $3.85 \mathrm{E}+01$ \\
\hline PBL15-1 & 15 & 1. & 98809767 & 27-Jul & Gross A & 1510 & $\mathrm{U}$ & $8.03 E+02$ & $4.97 \mathrm{E}+02$ \\
\hline PBL15-1 & 15 & 1 & 98809767 & 27-Jul & Gross B & 2600 & $\mathrm{U}$ & $-7.03 E+02$ & $6.74 E+02$ \\
\hline PBL15-1 & 15 & 1 & 98809767 & 27-Jul & Ac-228 & 130 & & $9.05 E+02$ & $5.70 \mathrm{E}+01$ \\
\hline PBL15-1 & 15 & 1 & 98809767 & 27-Jul & $B i-212$ & 300 & & $7.78 \mathrm{E}+02$ & $1.62 \mathrm{E} \div 02$ \\
\hline PBL15-1 & 15 & 1 & 98809767 & 27-Jul & Bi-214 & 70 & & $6.43 E+02$ & $5.43 \mathrm{E}+01$ \\
\hline PBL15-1 & 15 & 1 & 98809767 & 27-Jul & Co-60 & 40 & $\mathrm{U}$ & $1.29 \mathrm{E}+01$ & $1.09 \mathrm{E}+01$ \\
\hline PBL15-1 & 15 & 1 & 98809767 & 27-Jul & Cs-137 & 50 & U & $5.03 \mathrm{E}+00$ & $1.42 \mathrm{E}+01$ \\
\hline PBL15-1 & 15 & 1 & 98809767 & 27-Jul & $\mathrm{K}-40$ & 390 & & $5.38 \mathrm{E}+02$ & $2.78 E+02$ \\
\hline PBL15-1 & 15 & 1 & 98809767 & 27-Jul & $\mathrm{Pb}-212$ & 80 & & $8.97 \mathrm{E}+02$ & $6.22 \mathrm{E}+01$ \\
\hline PBL15-1 & 15 & 1 & 98809767 & 27-Jul & $\mathrm{Pb}-214$ & 90 & & $5.86 \mathrm{E}+02$ & $5.76 \mathrm{E}+01$ \\
\hline PBL15-1 & 15 & 1 & 98809767 & 27-Jul & T1-208 & 40 & - & $2.92 \mathrm{E}+02$ & $3.31 E+01$ \\
\hline PBL15-2 & 15 & 2 & 98809768 & 27-Jul & Gross A & 4750 & & $6.38 \mathrm{E}+03$ & $2.19 E+03$ \\
\hline PBL15-2 & 15 & 2 & 98809768 & 27-Jul & Gross B & 8130 & $\mathrm{U}$ & $-1.75 E+02$ & $2.26 \mathrm{E}+03$ \\
\hline PBL15-2 & 15 & 2 & 98809768 & 27-Jul & Ac-228 & 150 & & $1.08 \mathrm{E}+03$ & $8.47 \mathrm{E}+01$ \\
\hline PBL15-2 & 15 & 2 & 98809768 & 27-Jul & Bi-212 & 360 & & $5.24 E+02$ & $1.84 \mathrm{E}+02$ \\
\hline PBL15-2 & 15 & 2 & 98809768 & 27-Jul & $\mathrm{Bi}-214$ & 100 & & $7.89 \mathrm{E}+02$ & $6.24 \mathrm{E}+01$ \\
\hline PBL15-2 & 15 & 2 & 98809768 & 27-Jul & Co-60 & 50 & $\mathrm{U}$ & $1.93 E+01$ & $1.10 \mathrm{E}+01$ \\
\hline PBL15-2 & 15 & 2 & 98809768 & 27-Jul & Cs-137 & 60 & $\mathrm{U}$ & $-2.68 \mathrm{E}+01$ & $1.68 \mathrm{E}+01$ \\
\hline PBL15-2 & 15 & 2 & 98809768 & 27-Jul & $\mathrm{K}-40$ & 410 & & $1.29 \mathrm{E}+03$ & $2.51 E+02$ \\
\hline
\end{tabular}




\begin{tabular}{|l|c|c|c|c|l|c|c|c|c|}
\hline $\begin{array}{c}\text { Sample } \\
\text { Number }\end{array}$ & $\begin{array}{c}\text { Trans. } \\
\mathbf{m}\end{array}$ & $\begin{array}{c}\text { Depth } \\
\text { Int. }\end{array}$ & $\begin{array}{c}\text { Anal. Lab } \\
\mathbf{W}\end{array}$ & Date & Analyte & DL (pCi/kg) & Qual. & $\begin{array}{c}\text { Activity } \\
\text { (pCi/kg) }\end{array}$ & $\begin{array}{c} \pm 1 \text { Sigma } \\
\text { (pCi/kg) }\end{array}$ \\
\hline PBL15-2 & 15 & 2 & 98809768 & 27-Jul & Pb-212 & 90 & & $1.16 \mathrm{E}+03$ & $8.47 \mathrm{E}+01$ \\
\hline PBL15-2 & 15 & 2 & 98809768 & 27-Jul & Pb-214 & 120 & & $7.38 \mathrm{E}+02$ & $6.23 \mathrm{E}+01$ \\
\hline PBL15-2 & 15 & 2 & 98809768 & 27-Jul & Tl-208 & 50 & & $2.73 \mathrm{E}+02$ & $3.49 \mathrm{E}+01$ \\
\hline PBL15-3 & 15 & 3 & 98809766 & 27-Jul & Gross A & 1620 & $\mathrm{U}$ & $6.54 \mathrm{E}+02$ & $4.99 \mathrm{E}+02$ \\
\hline PBL15-3 & 15 & 3 & 98809766 & 27-Jul & Gross B & 2650 & $\mathrm{U}$ & $1.11 \mathrm{E}+03$ & $7.96 \mathrm{E}+02$ \\
\hline PBL15-3 & 15 & 3 & 98809766 & 27-Jul & Ac-228 & 180 & & $1.21 \mathrm{E}+03$ & $9.65 \mathrm{E}+01$ \\
\hline PBL15-3 & 15 & 3 & 98809766 & 27-Jul & Bi-212 & 380 & & $8.05 \mathrm{E}+02$ & $1.97 \mathrm{E}+02$ \\
\hline PBL15-3 & 15 & 3 & 98809766 & 27-Jul & Bi-214 & 100 & & $7.19 \mathrm{E}+02$ & $6.69 \mathrm{E}+01$ \\
\hline PBL15-3 & 15 & 3 & 98809766 & 27-Jul & Co-60 & 50 & $\mathrm{U}$ & $3.27 \mathrm{E}+00$ & $1.32 \mathrm{E}+01$ \\
\hline PBL15-3 & 15 & 3 & 98809766 & 27-Jul & Cs-137 & 60 & $\mathrm{U}$ & $-6.65 \mathrm{E}+00$ & $1.76 \mathrm{E}+01$ \\
\hline PBL15-3 & 15 & 3 & 98809766 & 27-Jul & K-40 & 470 & & $6.08 \mathrm{E}+02$ & $2.62 \mathrm{E}+02$ \\
\hline PBL15-3 & 15 & 3 & 98809766 & 27-Jul & Pb-212 & 110 & & $1.12 \mathrm{E}+03$ & $8.01 \mathrm{E}+01$ \\
\hline PBL15-3 & 15 & 3 & 98809766 & 27-Jul & Pb-214 & 120 & & $6.92 \mathrm{E}+02$ & $6.38 \mathrm{E}+01$ \\
\hline PBL15-3 & 15 & 3 & 98809766 & 27-Jul & Tl-208 & 60 & & $4.16 \mathrm{E}+02$ & $3.99 \mathrm{E}+01$ \\
\hline
\end{tabular}


Upper Tier

\begin{tabular}{|c|c|c|c|c|c|c|c|c|c|}
\hline $\begin{array}{c}\text { Sample } \\
\text { Number }\end{array}$ & $\begin{array}{c}\text { Trans. } \\
\text { ID }\end{array}$ & $\begin{array}{c}\text { Depth } \\
\text { Int. }\end{array}$ & $\begin{array}{c}\text { Anal. Lab } \\
\text { ID }\end{array}$ & Date & Analyte & $\mathrm{DL}(\mathrm{pCi} / \mathrm{kg})$ & Qual. & $\begin{array}{l}\text { Activity } \\
\text { (pCi/kg) }\end{array}$ & $\begin{array}{c} \pm 1 \text { Sigma } \\
(\mathrm{pCi} / \mathrm{kg})\end{array}$ \\
\hline PBU1-1 & 1 & 1 & 98809844 & 28-Jul & Gross A & 1970 & & $3.32 \mathrm{E}+03$ & $6.95 \mathrm{E}+02$ \\
\hline PBU1-1 & 1 & 1 & 98809844 & 28-Jul & Gross B & 3180 & $\mathrm{U}$ & $2.32 \mathrm{E}+03$ & $7.36 \mathrm{E}+02$ \\
\hline PBU1-1 & 1 & 1 & 98809844 & 28-Jul & Ac-228 & 160 & & $1.40 \mathrm{E}+03$ & $1.01 E+02$ \\
\hline PBU1-1 & 1 & 1 & 98809844 & 28-Jul & $\mathrm{Bi}-212$ & 450 & & $1.09 \mathrm{E}+03$ & $2.08 E+02$ \\
\hline PBU1-1 & 1 & 1 & 98809844 & 28-Jul & $B i-214$ & 100 & & $8.62 E+02$ & $6.77 E+01$ \\
\hline PBU1-1 & 1 & 1 & 98809844 & 28-Jul & Co-60 & 60 & $\mathrm{U}$ & $1.64 \mathrm{E}+01$ & $1.43 E+01$ \\
\hline PBU1-1 & 1 & 1 & 98809844 & 28-Jul & Cs-137 & 80 & U & $6.08 \mathrm{E}+01$ & $2.14 \mathrm{E}+01$ \\
\hline PBU1-i & 1 & 1 & 98809844 & 28-Jul & $\mathrm{K}-40$ & 420 & & $2.00 \mathrm{E}+03$ & $3.16 \mathrm{E}+02$ \\
\hline PBU1-1 & 1 & 1 & 98809844 & 28-Jul & $\mathrm{Pb}-212$ & 110 & & $1.26 \mathrm{E}+03$ & $8.05 E+01$ \\
\hline PBU1-1 & 1 & 1 & 98809844 & 28-Jul & $\mathrm{Pb}-214$ & 120 & & $7.78 \mathrm{E}+02$ & $6.95 E+01$ \\
\hline PBU1-1 & 1 & 1 & 98809844 & 28-Jul & Tl-208 & 60. & & $4.46 \mathrm{E}+02$ & $4.27 \mathrm{E}+01$ \\
\hline PBU1-2 & 1 & 2 & 98809847 & 28-Jul & Gross A & 2060 & & $3.32 E+03$ & $1.01 E+03$ \\
\hline PBU1-2 & 1 & 2 & 98809847 & 28-Jul & Gross B & 3100 & & $4.08 \mathrm{E}+03$ & $1.11 E+03$ \\
\hline PBU1-2 & 1 & 2 & 98809847 & 28-Jul & Ac-228 & 210 & & $1.88 \mathrm{E}+03$ & $1.21 \mathrm{E}+02$ \\
\hline PBU1-2 & 1 & 2 & 98809847 & 28-Jul & $\mathrm{Bi}-212$ & 510 & & $1.34 \mathrm{E}+03$ & $2.31 E+02$ \\
\hline PBU1-2 & 1 & 2 & 98809847 & 28-Jul & $\mathrm{Bi}-214$ & 130 & & $9.46 \mathrm{E}+02$ & $8.08 \mathrm{E}+01$ \\
\hline PBU1-2 & 1 & 2 & 98809847 & 28-Jul & Co-60 & 60 & $\mathrm{U}$ & $1.56 \mathrm{E}+01$ & $1.55 \mathrm{E}+01$ \\
\hline PBU1-2 & 1 & 2 & 98809847 & 28-Jul & Cs-137 & 80 & $\mathrm{U}$ & $4.86 \mathrm{E}+01$ & $2.04 \mathrm{E}+01$ \\
\hline PBU1-2 & 1 & 2 & 98809847 & 28-Jul & $\mathrm{K}-40$ & 470 & & $8.49 E+02$ & $3.16 \mathrm{E}+02$ \\
\hline PBU1-2 & 1 & 2 & 98809847 & 28-Jul & $\mathrm{Pb}-212$ & 150 & & $1.54 \mathrm{E}+03$ & $1.04 \mathrm{E}+02$ \\
\hline PBU1-2 & 1 & 2 & 98809847 & 28-Jul & $\mathrm{Pb}-214$ & 130 & & $9.92 \mathrm{E}+02$ & $8.77 \mathrm{E}+01$ \\
\hline PBU1-2 & 1 & 2 & 98809847 & 28-Jul & Tl-208 & 60 & & $5.49 E+02$ & $5.32 \mathrm{E}+01$ \\
\hline PBU1-3 & 1 & 3 & 98809845 & 28-Jul & Gross A & 2150 & & $2.19 E+03$ & $8.73 E+02$ \\
\hline PBU1-3 & 1 & 3 & 98809845 & 28-Jul & Gross B & 3140 & $\mathrm{U}$ & $2.70 \mathrm{E}+03$ & $1.05 E+03$ \\
\hline PBU1-3 & 1 & 3 & 98809845 & 28-Jul & Ac-228 & 220 & & $1.83 E+03$ & $1.25 \mathrm{E}+02$ \\
\hline PBUI-3 & 1 & 3 & 98809845 & 28-Jul & $\mathrm{Bi}-212$ & 550 & & $1.46 \mathrm{E}+03$ & $3.78 E+02$ \\
\hline
\end{tabular}




\begin{tabular}{|c|c|c|c|c|c|c|c|c|c|}
\hline $\begin{array}{l}\text { Sample } \\
\text { Number }\end{array}$ & $\begin{array}{c}\text { Trans. } \\
\text { ID }\end{array}$ & $\begin{array}{c}\text { Depth } \\
\text { Int. }\end{array}$ & $\begin{array}{c}\text { Anal. Lab } \\
\text { ID }\end{array}$ & Date & Analyte & $\mathrm{DL}(\mathrm{pCi} / \mathrm{kg})$ & Qual. & $\begin{array}{l}\text { Activity } \\
\text { (pCi/kg) }\end{array}$ & $\begin{array}{c} \pm 1 \text { Sigma } \\
(\mathrm{pCi} / \mathrm{kg})\end{array}$ \\
\hline PBU1-3 & 1 & 3 & 98809845 & 28-Jul & $\mathrm{Bi}-214$ & 130 & & $1.09 E+03$ & $8.30 \mathrm{E}+01$ \\
\hline PBU1-3 & 1 & 3 & 98809845 & 28-Jul & Co-60 & 60 & $\mathrm{U}$ & $1.58 \mathrm{E}+01$ & $1.57 \mathrm{E}+01$ \\
\hline PBU1-3 & 1 & 3 & 98809845 & 28-Jul & Cs- 137 & 70 & $\mathrm{U}$ & $-1.58 \mathrm{E}+01$ & $1.99 \mathrm{E}+01$ \\
\hline PBU1-3 & 1 & 3 & 98809845 & $28-J u l$ & $\mathrm{~K}-40$ & 610 & & $1.95 E+03$ & $3.76 \mathrm{E}+02$ \\
\hline PBU1-3 & 1 & 3 & 98809845 & 28-Jul & $\mathrm{Pb}-212$ & 130 & & $1.87 \mathrm{E}+03$ & $1.11 \mathrm{E}+02$ \\
\hline PBU1-3 & 1 & 3 & 98809845 & 28-Jul & $\mathrm{Pb}-214$ & 130 & & $1.09 \mathrm{E}+03$ & $8.32 E+01$ \\
\hline PBU1-3 & 1 & 3 & 98809845 & 28-Jul & $\mathrm{Tl}-208$ & 70 & & $7.16 \mathrm{E}+02$ & $5.41 \mathrm{E}+01$ \\
\hline PBU3-1 & 3 & 1 & 98809832 & 28-Jul & Gross A & 7170 & $\mathrm{U}$ & $3.89 \mathrm{E}+03$ & $1.89 \mathrm{E}+03$ \\
\hline PBU3-1 & 3 & 1 & 98809832 & 28-Jul & Gross B & 12160 & $\mathrm{U}$ & $6.78 \mathrm{E}+02$ & $3.09 E+03$ \\
\hline PBU3-1 & 3 & 1 & 98809832 & 28-Jul & Ac-228 & 190 & & $1.21 E+03$ & $9.59 E+01$ \\
\hline PBU3-1 & 3 & 1 & 98809832 & 28-Jul & $\mathrm{Bi}-212$ & 450 & & $8.03 E+02$ & $2.09 \mathrm{E}+02$ \\
\hline PBU3-1 & 3 & 1 & 98809832 & 28-Jul & $\mathrm{Bi}-214$ & 110 & & $1.01 \mathrm{E}+03$ & $7.46 \mathrm{E}+01$ \\
\hline PBU3-1 & 3 & 1 & 98809832 & 28-Jul & $\mathrm{Co}-60$ & 50 & $\mathrm{U}$ & $1.32 \mathrm{E}+01$ & $1.32 \mathrm{E}+01$ \\
\hline PBU3-1 & 3 & 1 & 98809832 & 28-Jul & Cs-137 & 60 & & $6.19 E+01$ & $2.54 \mathrm{E}+01$ \\
\hline PBU3-1 & 3 & 1 & 98809832 & 28-Jul & $\mathrm{K}-40$ & 1190 & $\mathrm{U}$ & $5.08 \mathrm{E}+02$ & $2.73 E+02$ \\
\hline PBU3-1 & 3 & 1 & 98809832 & 28-Jul & $\mathrm{Pb}-212$ & 110 & & $1.25 \mathrm{E}+03$ & $8.45 E+01$ \\
\hline PBU3-1 & 3 & 1 & 98809832 & 28-Jul & $\mathrm{Pb}-214$ & 120 & & $1.04 \mathrm{E}+03$ & $7.38 \mathrm{E}+01$ \\
\hline PBU3-1 & 3 & 1 & 98809832 & 28-Jul & Tl-208 & 50 & & $4.35 E+02$ & $4.31 \mathrm{E}+01$ \\
\hline PBU3-2 & 3 & 2 & 98809835 & 28-Jul & Gross A & 4660 & $\mathrm{U}$ & $3.65 \mathrm{E}+03$ & $1.73 E+03$ \\
\hline PBU3-2 & 3 & 2 & 98809835 & 28-Jul & Gross B & 7860 & $U$ & $6.84 \mathrm{E}+01$ & $2.20 \mathrm{E}+03$ \\
\hline PBU3-2 & 3 & 2 & 98809835 & 28-Jul & Ac-228 & 150 & & $1.13 E+03$ & $9.66 E+01$ \\
\hline PBU3-2 & 3 & 2 & 98809835 & 28-Jul & $\mathrm{Bi}-212$ & 430 & & $9.89 \mathrm{E}+02$ & $2.22 \mathrm{E}+02$ \\
\hline PBU3-2 & 3 & 2 & 98809835 & 28-Jul & Bi-214 & 100 & & $9.03 E+02$ & $6.49 \mathrm{E}+01$ \\
\hline PBU3-2 & 3 & 2 & 98809835 & 28-Jul & Co-60 & 60 & $\mathrm{U}$ & $1.24 \mathrm{E}+01$ & $1.46 \mathrm{E}+01$ \\
\hline PBU3-2 & 3 & 2 & 98809835 & 28-Jul & Cs-137 & 60 & $\mathrm{U}$ & $1.24 \mathrm{E}+01$ & $1.55 \mathrm{E}+01$ \\
\hline PBU3-2 & 3 & 2 & 98809835 & 28-Jul & $\mathrm{K}-40$ & 440 & & $1.01 \mathrm{E}+03$ & $2.88 \mathrm{E}+02$ \\
\hline PBU3-2 & 3 & 2 & 98809835 & 28-Jul & $\mathrm{Pb}-212$ & 110 & & $1.04 E+03$ & $7.23 \mathrm{E}+01$ \\
\hline
\end{tabular}




\begin{tabular}{|c|c|c|c|c|c|c|c|c|c|}
\hline $\begin{array}{r}\text { Sample } \\
\text { Number }\end{array}$ & $\begin{array}{c}\text { Trans. } \\
\text { ID }\end{array}$ & $\begin{array}{c}\text { Depth } \\
\text { Int. }\end{array}$ & $\begin{array}{c}\text { Anal. Lab } \\
\text { ID }\end{array}$ & Date & Analyte & $\mathrm{DL}(\mathrm{pCi} / \mathrm{kg})$ & Qual. & $\begin{array}{l}\text { Activity } \\
\text { (pCi/kg) }\end{array}$ & $\begin{array}{c} \pm 1 \text { Sigma } \\
(\mathrm{pCi} / \mathrm{kg})\end{array}$ \\
\hline PBU3-2 & 3 & 2 & 98809835 & 28-Jul & $\mathrm{Pb}-214$ & 120 & & $8.95 \mathrm{E}+02$ & $6.91 \mathrm{E}+01$ \\
\hline PBU3-2 & 3 & 2 & 98809835 & 28-Jul & TI-208 & 60 & & $4.00 \mathrm{E}+02$ & $4.20 \mathrm{E}+01$ \\
\hline PBU3-3 & 3 & 3 & 98809833 & 28-Jul & Gross A & 4660 & $\mathrm{U}$ & $2.56 \mathrm{E}+03$ & $1.58 \mathrm{E}+03$ \\
\hline PBU3-3 & 3 & 3 & 98809833 & 28-Jul & Gross B & 7810 & $\mathrm{U}$ & $2.70 \mathrm{E}+03$ & $2.32 E+03$ \\
\hline PBU3-3 & 3 & 3 & 98809833 & 28-Jul & Ac-228 & 180 & & $1.12 \mathrm{E}+03$ & $7.70 \mathrm{E}+01$ \\
\hline PBU3-3 & 3 & 3 & 98809833 & 28-Jul & $\mathrm{Bi}-212$ & 360 & & $9.35 \mathrm{E}+02$ & $2.32 \mathrm{E}+02$ \\
\hline PBU3-3 & 3 & 3 & 98809833 & 28-Jul & $\mathrm{Bi}-214$ & 90 & & $8.59 E+02$ & $6.36 \mathrm{E}+01$ \\
\hline PBU3-3 & 3 & 3 & 98809833 & 28-Jul & Co- 60 & 50 & $\mathbf{U}$ & $2.84 \mathrm{E}+00$ & $1.45 \mathrm{E}+01$ \\
\hline PBU3-3 & 3 & 3 & 98809833 & 28-Jul & Cs- 137 & 50 & $U$ & $7.16 \mathrm{E}+00$ & $1.69 E+01$ \\
\hline PBU3-3 & 3 & 3 & 98809833 & 28-Jul & $\mathrm{K}-40$ & 350 & & $9.24 \mathrm{E}+02$ & $2.58 \mathrm{E}+02$ \\
\hline PBU3-3 & 3 & 3 & 98809833 & 28-Jul & $\mathrm{Pb}-212$ & 110 & & $1.03 E+03$ & $7.30 \mathrm{E}+01$ \\
\hline PBU3-3 & 3 & 3 & 98809833 & 28-Jul & $\mathrm{Pb}-214$ & 120 & & $8.41 E+02$ & $7.08 \mathrm{E}+01$ \\
\hline PBU3-3 & 3 & 3 & 98809833 & 28-Jul & Tl-208 & 60 & & $3.86 \mathrm{E}+02$ & $4.22 E+01$ \\
\hline PBU5-1 & 5 & 1 & 98809724 & 28-Jul & Gross A & 1830 & $\mathrm{U}$ & $7.81 \mathrm{E}+02$ & $5.64 E+02$ \\
\hline PBU5-1 & 5 & 1 & 98809724 & 28-Jul & Gross B & 3110 & $\mathrm{U}$ & $-2.52 \mathrm{E}+02$ & $8.49 E+02$ \\
\hline PBU5-1 & 5 & 1 & 98809724 & 28-Jul & Ac-228 & 180 & & $1.11 \mathrm{E}+03$ & $8.65 E+01$ \\
\hline PBU5-1 & 5 & 1 & 98809724 & 28-Jul & $\mathrm{Bi}-212$ & 370 & & $9.78 E+02$ & $1.73 E+02$ \\
\hline PBU5-1 & 5 & 1 & 98809724 & 28-Jul & Bi-214 & 100 & & $7.57 \mathrm{E}+02$ & $6.09 E+01$ \\
\hline PBU5-1 & 5 & 1 & 98809724 & 28-Jul & Co-60 & 50 & $\mathrm{U}$ & $1.42 \mathrm{E}+01$ & $1.18 \mathrm{E}+01$ \\
\hline PBU5-1 & 5 & 1 & 98809724 & 28-Jul & Cs- 137 & 60 & $U$ & $1.21 E+01$ & $1.65 \mathrm{E}+01$ \\
\hline PBU5-1 & 5 & 1 & 98809724 & 28-Jul & $\mathrm{K}-40$ & 530 & & $6.14 E+02$ & $3.04 \mathrm{E}+02$ \\
\hline PBU5-1 & 5 & 1 & 98809724 & 28-Jul & $\mathrm{Pb}-212$ & 100 & & $9.57 E+02$ & $6.72 \mathrm{E}+01$ \\
\hline PBU5-1 & 5 & 1 & 98809724 & 28-Jul & $\mathrm{Pb}-214$ & 110 & & $6.62 \mathrm{E}+02$ & $6.62 \mathrm{E}+01$ \\
\hline PBU5-1 & 5 & 1 & 98809724 & 28-Jul & TI-208 & 50 & & $3.73 E+02$ & $3.61 E+01$ \\
\hline PBU5-2 & 5 & 2 & 98809727 & 28-Jul & Gross A & 1830 & & $2.35 \mathrm{E}+03$ & $8.07 E+02$ \\
\hline PBU5-2 & 5 & 2 & 98809727 & 28-Jul & Gross B & 3110 & $\mathrm{U}$ & $2.89 E+02$ & $8.92 E+02$ \\
\hline PBU5-2 & 5 & 2 & 98809727 & 28-Jul & Ac-228 & 190 & & $1.06 \mathrm{E}+03$ & $8.96 \mathrm{E}+01$ \\
\hline
\end{tabular}




\begin{tabular}{|c|c|c|c|c|c|c|c|c|c|}
\hline $\begin{array}{l}\text { Sample } \\
\text { Number }\end{array}$ & $\begin{array}{c}\text { Trans. } \\
\text { ID }\end{array}$ & $\begin{array}{c}\text { Depth } \\
\text { Int. }\end{array}$ & $\begin{array}{l}\text { Anal. Lab } \\
\text { ID }\end{array}$ & Date & Analyte & $\mathrm{DL}(\mathrm{pCi} / \mathrm{kg})$ & Qual. & $\begin{array}{l}\text { Activity } \\
\text { (pCi/kg) }\end{array}$ & $\begin{array}{c} \pm 1 \text { Sigma } \\
(\mathrm{pCi} / \mathrm{kg})\end{array}$ \\
\hline PBU5-2 & 5 & 2 & 98809727 & 28-Jul 1 & $\mathrm{Bi}-212$ & 420 & & $8.24 \mathrm{E}+02$ & $1.93 E+02$ \\
\hline PBU5-2 & 5 & 2 & 98809727 & 28-Jul & $\mathrm{Bi}-214$ & 90 & & $7.81 \mathrm{E}+02$ & $6.46 \mathrm{E}+01$ \\
\hline PBU5-2 & 5 & 2 & 98809727 & 28-Jul & Co-60; & 60 & $\mathrm{U}$ & $3.14 \mathrm{E}+01$ & $1.30 \mathrm{E}+01$ \\
\hline PBU5-2 & 5 & 2 & 98809727 & 28-Jul & Cs-137 & 60 & $\mathrm{U}$ & $2.56 \mathrm{E}+01$ & $1.69 \mathrm{E}+01$ \\
\hline PBU5-2 & 5 & 2 & 98809727 & 28-Jul & $\mathrm{K}-40$ & 490 & & $6.97 \mathrm{E}+02$ & $3.05 E+02$ \\
\hline PBU5-2 & 5 & 2 & 98809727 & 28-Jul & $\mathrm{Pb}-212$ & 100 & & $1.07 \mathrm{E}+03$ & $7.54 \mathrm{E}+01$ \\
\hline PBU5-2 & 5 & 2 & 98809727 & 28-Jul & $\mathrm{Pb}-214$ & 110 & & $7.57 \mathrm{E}+02$ & $6.99 \mathrm{E}+01$ \\
\hline PBU5-2 & 5 & 2 & 98809727 & 28-Jul & TI-208 & 60 & & $2.97 \mathrm{E}+02$ & $4.12 E+01$ \\
\hline PBU5-3 & 5 & 3 & 98809725 & 28-Jul & Gross A & 1800 & $\mathrm{U}$ & $9.57 \mathrm{E}+02$ & $5.99 \mathrm{E}+02$ \\
\hline PBU5-3 & 5 & 3 & 98809725 & 28-Jul & Gross B & 3090 & $\mathrm{U}$ & $1.20 \mathrm{E}+03$ & $9.27 \mathrm{E}+02$ \\
\hline PBU5-3 & 5 & 3 & 98809725 & $28-\mathrm{Jul}$ & Ac-228 & 150 & & $1.08 \mathrm{E}+03$ & $8.91 E+01$ \\
\hline PBU5-3 & 5 & 3 & 98809725 & 28-Jul & $\mathrm{Bi}-212$ & 430 & & $8.57 \mathrm{E}+02$ & $1.74 \mathrm{E}+02$ \\
\hline PBU5-3 & 5 & 3. & 98809725 & 28-Jul & $\mathrm{Bi}-214$ & 100 & & $8.65 E+02$ & $6.16 \mathrm{E}+01$ \\
\hline PBU5-3 & 5 & 3 & 98809725 & 28-Jul & Co-60 & 60 & $\mathrm{U}$ & $2.73 E+01$ & $1.33 \mathrm{E}+01$ \\
\hline PBU5-3 & 5 & 3 & 98809725 & 28-Jul & Cs-137 & 50 & $\mathrm{U}$ & $-8.70 E+00$ & $1.47 \mathrm{E}+01$ \\
\hline PBU5-3 & 5 & 3 & 98809725 & 28-Jul & $\mathrm{K}-40$ & 350 & & $1.09 \mathrm{E}+03$ & $2.89 E+02$ \\
\hline PBU5-3 & 5 & 3 & 98809725 & 28-Jul & $\mathrm{Pb}-212$ & 100 & & $9.76 E+02$ & $7.03 E+01$ \\
\hline PBU5-3 & 5 & 3 & 98809725 & 28-Jul & $\mathrm{Pb}-214$ & 120 & & $8.57 \mathrm{E}+02$ & $7.27 \mathrm{E}+01$ \\
\hline PBU5-3 & 5 & 3 & 98809725 & 28-Jul & T1-208 & 60 & & $3.51 E+02$ & $3.42 \mathrm{E}+01$ \\
\hline PBU5-3B & 5 & 3 & 98809730 & 28-Jul & Gross A & 1810 & $\mathrm{U}$ & $1.38 \mathrm{E}+03$ & $6.85 E+02$ \\
\hline PBU5-3B & 5 & 3 & 98809730 & 28-Jul & Gross B & 3100 & $U$ & $1.92 E+03$ & $9.86 \mathrm{E}+02$ \\
\hline PBU5-3B & 5 & 3 & 98809730 & 28-Jul & Ac-228 & 150 & & $1.10 E+03$ & $9.00 \mathrm{E}+01$ \\
\hline PBU5-3B & 5 & 3 & 98809730 & 28-Jul & $\mathrm{Bi}-212$ & 370 & & $1.06 \mathrm{E}+03$ & $2.07 \mathrm{E}+02$ \\
\hline PBU5-3B & 5 & 3 & 98809730 & 28-Jul & $\mathrm{Bi}-214$ & 100 & & $7.84 \mathrm{E}+02$ & $6.18 \mathrm{E}+01$ \\
\hline PBU5-3B & 5 & 3 & 98809730 & 28-Jul & Co-60 & 50 & $\mathrm{U}$ & $2.69 \mathrm{E}-01$ & $1.24 \mathrm{E}+01$ \\
\hline PBU5-3B & 5 & 3 & 98809730 & 28-Jul & Cs- 137 & 60 & $\mathrm{U}$ & $2.22 \mathrm{E}+01$ & $1.50 \mathrm{E}+01$ \\
\hline PBU5-3B & 5 & 3 & 98809730 & 28-Jul & $\mathrm{K}-40$ & 1170 & U & $7.16 \mathrm{E}+02$ & $2.66 \mathrm{E}+02$ \\
\hline
\end{tabular}




\begin{tabular}{|c|c|c|c|c|c|c|c|c|c|}
\hline $\begin{array}{c}\text { Sample } \\
\text { Number }\end{array}$ & $\begin{array}{c}\text { Trans. } \\
\text { ID }\end{array}$ & $\begin{array}{l}\text { Depth } \\
\text { Int. }\end{array}$ & $\begin{array}{c}\text { Anal. Lab } \\
\text { ID }\end{array}$ & Date & Analyte & $\mathrm{DL}(\mathrm{pCi} / \mathrm{kg})$ & Qual. & $\begin{array}{l}\text { Activity } \\
\text { (pCi/kg) }\end{array}$ & $\begin{array}{c} \pm 1 \text { Sigma } \\
(\mathrm{pCi} / \mathrm{kg})\end{array}$ \\
\hline PBU5-3B & 5 & 3 & 98809730 & 28-Jul & $\mathrm{Pb}-212$ & 100 & & $1.05 E+03$ & $7.41 E+01$ \\
\hline PBU5-3B & 5 & 3 & 98809730 & 28-Jul & $\mathrm{Pb}-214$ & 120 & & $9.41 E+02$ & $7.23 E+01$ \\
\hline PBU5-3B & 5 & 3 & 98809730 & 28-Jul & $\mathrm{Tl}-208$ & 60 & & $3.43 E+02$ & $3.84 \mathrm{E}+01$ \\
\hline PBU7-1 & 7 & 1 & 98809728 & 28-Jul & Gross A & 1850 & & $2.37 E+03$ & $8.16 \mathrm{E}+02$ \\
\hline PBU7-1 & 7 & 1 & 98809728 & 28-Jul & Gross B & 3090 & $\mathrm{U}$ & $1.18 \mathrm{E}+03$ & $9.36 \mathrm{E}+02$ \\
\hline PBU7-1 & 7 & 1 & 98809728 & 28-Jul & Ac-228 & 190 & & $1.29 \mathrm{E}+03$ & $9.26 \mathrm{E}+01$ \\
\hline PBU7-1 & 7 & 1 & 98809728 & 28-Jul & $\mathrm{Bi}-212$ & 430 & & $7.86 \mathrm{E}+02$ & $1.93 E+02$ \\
\hline PBU7-1 & 7 & 1 & 98809728 & 28-Jul & $B i-214$ & 110 & & $1.04 \mathrm{E}+03$ & $7.61 E+01$ \\
\hline PBU7-1 & 7 & 1 & 98809728 & 28-Jul & Co-60 & 50 & $\mathrm{U}$ & $7.38 \mathrm{E}+00$ & $1.29 \mathrm{E}+01$ \\
\hline PBU7-1 & 7 & 1 & 98809728 & 28-Jul & Cs-137 & 60 & & $2.84 \mathrm{E}+02$ & $4.31 \mathrm{E}+01$ \\
\hline PBU7-1 & 7 & 1 & 98809728 & 28-Jul & $\mathrm{K}-40$ & 460 & & $1.15 E+03$ & $2.86 \mathrm{E}+02$ \\
\hline PBU7-1 & 7 & 1 & 98809728 & 28-Jul & $\mathrm{Pb}-212$ & 120 & & $1.14 \mathrm{E}+03$ & $7.91 \mathrm{E}+01$ \\
\hline PBU7-1 & 7 & 1 & 98809728 & 28-Jul & $\mathrm{Pb}-214$ & 120 & & $1.01 E+03$ & $7.43 \mathrm{E}+01$ \\
\hline PBU7-1 & 7 & 1 & 98809728 & 28-Jul & $\mathrm{Tl}-208$ & 60 & & $4.59 \mathrm{E}+02$ & $4.12 E+01$ \\
\hline PBU7-2 & 7 & 2 & 98809726 & 28-Jul & Gross A & 1830 & & $3.65 \mathrm{E}+03$ & $9.82 \mathrm{E}+02$ \\
\hline PBUT-2 & 7 & 2 & 98809726 & 28-Jul & Gross B & 3100 & U & $1.20 \mathrm{E}+03$ & $9.46 \mathrm{E}+02$ \\
\hline PBU7-2 & 7 & 2 & 98809726 & 28-Jul & Ac-228 & 140 & & $1.23 E+03$ & $8.84 \mathrm{E}+01$ \\
\hline PBU7-2 & 7 & 2 & 98809726 & 28-Jul & $\mathrm{Bi}-212$ & 320 & & $9.70 E+02$ & $1.68 \mathrm{E}+02$ \\
\hline PBU7-2 & 7 & 2 & 98809726 & 28-Júl & Bi-214 & 100 & & $9.19 E+02$ & $6.61 \mathrm{E}+01$ \\
\hline PBU7-2 & 7 & 2 & 98809726 & 28-Jul & Co-60 & 40 & $U$ & $-2.37 \mathrm{E}+01$ & $1.34 E+01$ \\
\hline PBU7-2 & 7 & 2 & 98809726 & 28-Jul & Cs-137 & 60 & & $6.27 \mathrm{E}+01$ & $2.39 \mathrm{E}+01$ \\
\hline PBU7-2 & 7 & 2 & 98809726 & 28-Jul & $\mathrm{K}-40$ & 530 & & $6.89 E+02$ & $3.03 E+02$ \\
\hline PBU7-2 & 7 & 2 & 98809726 & 28-Jul & $\mathrm{Pb}-212$ & 140 & & $1.12 \mathrm{E}+03$ & $8.22 \mathrm{E}+01$ \\
\hline PBU7-2 & 7 & 2 & 98809726 & 28-Jul & $\mathrm{Pb}-214$ & 130 & & $9.35 E+02$ & $7.53 E+01$ \\
\hline PBU7-2 & 7 & 2 & 98809726 & 28-Jul & $\mathrm{Tl}-208$ & 40 & & $4.16 \mathrm{E}+02$ & $3.84 \mathrm{E}+01$ \\
\hline PBU7-3 & 7 & 3 & 98809729 & 28-Jul & Gross A & 1830 & $\dot{U}$ & $5.35 \mathrm{E}+02$ & $5.19 \mathrm{E}+02$ \\
\hline PBU7-3 & 7 & 3 & 98809729 & 28-Jul & Gross B & 3.120 & $U$ & $1.02 E+03$ & $9.34 \mathrm{E}+02$ \\
\hline
\end{tabular}




\begin{tabular}{|c|c|c|c|c|c|c|c|c|c|}
\hline $\begin{array}{l}\text { Sample } \\
\text { Number }\end{array}$ & \begin{tabular}{|} 
Trans. \\
ID
\end{tabular} & $\begin{array}{c}\text { Depth } \\
\text { Int. }\end{array}$ & $\begin{array}{c}\text { Anal. Lab } \\
\text { ID }\end{array}$ & Date & Analyte & $\mathrm{DL}(\mathrm{pCi} / \mathrm{kg})$ & Qual. & $\begin{array}{l}\text { Activity } \\
\text { (pCi/kg) }\end{array}$ & $\begin{array}{c} \pm 1 \text { Sigma } \\
(\mathrm{pCi} / \mathrm{kg})\end{array}$ \\
\hline PBU7-3 & 7 & 3 & 98809729 & 28-Jul & Ac-228 & 160 & & $1.25 \mathrm{E}+03$ & $1.03 E+02$ \\
\hline PBU7-3 & 7 & 3 & 98809729 & 28-Jul & $\mathrm{Bi}-212$ & 390 & & $1.04 \mathrm{E}+03$ & $2.01 E+02$ \\
\hline PBU7-3 & 7 & 3 & 98809729 & 28-Jul & $\mathrm{Bi}-214$ & 110 & & $8.62 E+02$ & $7.16 \mathrm{E}+01$ \\
\hline PBU7-3 & 7 & 3 & 98809729 & 28-Jul & Co-60 & 50 & $\mathrm{U}$ & $-1.09 \mathrm{E}+01$ & $1.36 \mathrm{E}+01$ \\
\hline PBU7-3 & 7 & 3 & 98809729 & 28-Jul & Cs-137 & 60 & $\mathrm{U}$ & $1.07 \mathrm{E}+01$ & $1.66 \mathrm{E}+01$ \\
\hline PBU7-3 & 7 & 3 & 98809729 & 28-Jul & $\mathrm{K}-40$ & 450 & & $7.05 E+02$ & $3.14 \mathrm{E}+02$ \\
\hline PBU7-3 & 7 & 3 & 98809729 & 28-Jul & $\mathrm{Pb}-212$ & 100 & & $1.14 \mathrm{E}+03$ & $7.41 \mathrm{E}+01$ \\
\hline PBU7-3 & 7 & 3 & 98809729 & $28-J u l$ & $\mathrm{~Pb}-214$ & 120 & & $9.14 \mathrm{E}+02$ & $6.96 \mathrm{E}+01$ \\
\hline PBU7-3 & 7 & 3 & 98809729 & 28-Jul & $\mathrm{Tl}-208$ & 60 & & $4.11 E+02$ & $3.74 \mathrm{E}+01$ \\
\hline PBU9-1 & 9 & 1 & 98809733 & 28-Jul & Gross A & 1710 & $\mathbf{U}$ & $1.53 \mathrm{E}+03$ & $6.69 \mathrm{E}+02$ \\
\hline PBU9-1 & 9 & 1 & 98809733 & 28-Jul & Gross B & 2920 & $U$ & $1.41 E+03$ & $8.95 \mathrm{E}+02$ \\
\hline PBU9-1 & 9 & 1 & 98809733 & 28-Jul & Ac-228 & 160 & & $1.09 \mathrm{E}+03$ & $8.73 E+01$ \\
\hline PBU9-1 & 9 & 1 & 98809733 & 28-Jul & Bi-214 & 110 & & $9.03 E+02$ & $6.95 \mathrm{E}+01$ \\
\hline PBU9-1 & 9 & 1 & 98809733 & 28-Jul & Co-60 & 50 & $\mathrm{U}$ & $1.86 \mathrm{E}+01$ & $1.31 \mathrm{E}+01$ \\
\hline PBU9-1 & 9 & 1 & 98809733 & 28-Jul & Cs-137 & 50 & & $1.35 \mathrm{E}+02$ & $2.46 \mathrm{E}+01$ \\
\hline PBU9-1 & 9 & 1 & 98809733 & 28-Jul & $\mathrm{K}-40$ & 990 & $U$ & $2.38 \mathrm{E}+02$ & $2.24 \mathrm{E}+02$ \\
\hline PBU9-1 & 9 & 1 & 98809733 & 28-Jul & $\mathrm{Pb}-212$ & 140 & & $1.04 \mathrm{E}+03$ & $8.23 E+01$ \\
\hline PBU9-1 & 9 & 1 & 98809733 & 28-Jul & $\mathrm{Pb}-214$ & 110 & & $7.86 \mathrm{E}+02$ & $7.43 E+01$ \\
\hline PBU9-1 & 9 & 1 & 98809733 & 28-Jul & Tl-208 & 60 & & $3.24 \mathrm{E}+02$ & $3.99 E+01$ \\
\hline PBU9-2 & 9 & 2 & 98809731 & 28-Jul & Gross A & 1740 & $\mathrm{U}$ & $9.24 \mathrm{E}+02$ & $5.77 E+02$ \\
\hline PBU9-2 & 9 & 2 & 98809731 & 28-Jul & Gross B & 2980 & $\mathrm{U}$ & $1.73 E+02$ & $8.36 \mathrm{E}+02$ \\
\hline PBU9-2 & 9 & 2 & 98809731 & 28-Jul & Ac-228 & .160 & & $9.81 \mathrm{E}+02$ & $8.81 E+01$ \\
\hline PBU9-2 & 9 & 2 & 98809731 & 28-Jul & Bi-212 & 340 & & $1.03 E+03$ & $2.47 \mathrm{E}+02$ \\
\hline PBU9-2 & 9 & 2 & 98809731 & 28-Jul & $\mathrm{Bi}-214$ & 90 & & $8.62 E+02$ & $5.89 E+01$ \\
\hline PBU9-2 & 9 & 2 & 98809731 & 28-Jul & Co-60 & 40 & $\mathrm{U}$ & $-6.76 E+00$ & $1.12 E+01$ \\
\hline PBU9-2 & 9 & 2 & 98809731 & 28-Jul & Cs-137 & 50 & $\mathrm{U}$ & $-1.85 E+01$ & $1.55 E+01$ \\
\hline PBU9-2 & 9 & 2 & 98809731 & 28-Jul & $\mathrm{K}-40$ & 410 & & $7.08 \mathrm{E}+02$ & $2.43 E+02$ \\
\hline
\end{tabular}




\begin{tabular}{|c|c|c|c|c|c|c|c|c|c|}
\hline $\begin{array}{r}\text { Sample } \\
\text { Number }\end{array}$ & $\begin{array}{c}\text { Trans. } \\
\text { ID }\end{array}$ & $\begin{array}{c}\text { Depth } \\
\text { Int. }\end{array}$ & $\begin{array}{c}\text { Anal. Lab } \\
\text { ID }\end{array}$ & Date & Analyte & $\mathrm{DL}(\mathrm{pCi} / \mathrm{kg})$ & Qual. & $\begin{array}{l}\text { Activity } \\
\text { (pCi/kg) }\end{array}$ & $\begin{array}{c} \pm 1 \text { Sigma } \\
(\mathrm{pCi} / \mathrm{kg})\end{array}$ \\
\hline PBU9-2 & 9 & 2 & 98809731 & 28-Jul & $\mathrm{Pb}-212$ & 100 & & $9.27 E+02$ & $6.77 \mathrm{E}+01$ \\
\hline PBU9-2 & 9 & 2 & 98809731 & 28-Jul & $\mathrm{Pb}-214$ & 110 & & $7.92 \mathrm{E}+02$ & $5.93 \mathrm{E}+01$ \\
\hline PBU9-2 & 9 & 2 & 98809731 & 28-Jul & TI-208 & 50 & & $4.05 E+02$ & $3.43 E+01$ \\
\hline PBU9-3 & 9 & 3 & 98809734 & 28-Jul & Gross A & 1740 & & $2.02 E+03$ & $7.51 \mathrm{E}+02$ \\
\hline PBU9-3 & 9 & 3 & 98809734 & 28-Jul & Gross B & 2970 & $\mathrm{U}$ & $1.61 E+03$ & $9.28 \mathrm{E}+02$ \\
\hline PBU9-3 & 9 & 3 & 98809734 & 28-Jul & Ac-228 & 150 & & $1.06 \mathrm{E}+03$ & $8.70 E+01$ \\
\hline PBU9-3 & 9 & 3 & 98809734 & 28-Jul & Bi-214 & 100 & & $6.08 \mathrm{E}+02$ & $5.80 \mathrm{E}+01$ \\
\hline PBU9-3 & 9 & 3 & 98809734 & 28-Jul & Co-60 & 50 & U & $3.00 \mathrm{E}+01$ & $1.24 \mathrm{E}+01$ \\
\hline PBU9-3 & 9 & 3 & 98809734 & 28-Jul & Cs-137 & 50 & $\mathrm{U}$ & $-1.60 \mathrm{E}+01$ & $1.55 \mathrm{E}+01$ \\
\hline PBU9-3 & 9 & 3 & 98809734 & 28-Jul & $\mathrm{K}-40$ & 440 & & $1.07 \mathrm{E}+03$ & $2.97 \mathrm{E}+02$ \\
\hline PBU9-3 & 9 & 3 & 98809734 & 28-Jul & $\mathrm{Pb}-212$ & 90 & & $1.02 \mathrm{E}+03$ & $7.05 \mathrm{E}+01$ \\
\hline PBU9-3 & 9 & 3 & 98809734 & 28-Jul & $\mathrm{Pb}-214$ & 100 & & $6.59 \mathrm{E}+02$ & $6.24 E+01$ \\
\hline PBU9-3 & 9 & 3 & 98809734 & 28-Jul & $\mathrm{T} 1-208$ & 50 & & $3.70 \mathrm{E}+02$ & $3.55 \mathrm{E}+01$ \\
\hline PBU11-1 & 11 & 1 & 98809808 & 27-Jul & Gross A & 1770 & $\mathrm{U}$ & $1.38 \mathrm{E}+03$ & $6.57 \mathrm{E}+02$ \\
\hline PBU11-1 & 11 & 1 & 98809808 & 27-Jul & Gross B & 2990 & $\mathrm{U}$ & $1.32 E+03$ & $9.11 E+02$ \\
\hline PBU11-1 & 11 & 1 & 98809808 & 27-Jul & Ac-228 & 160 & & $1.22 \mathrm{E}+03$ & $9.26 \mathrm{E}+01$ \\
\hline PBU11-1 & 11 & 1 & 98809808 & 27-Jul & $B i-212$ & 380 & & $1.09 \mathrm{E}+03$ & $2.00 \mathrm{E}+02$ \\
\hline PBU11-1 & 11 & 1 & 98809808 & 27-Jul & $\mathrm{Bi}-214$ & 100 & & $8.54 \mathrm{E}+02$ & $6.09 E+01$ \\
\hline PBU11-1 & 11 & 1 & 98809808 & 27-Jul & $\mathrm{Co}-60$ & 50 & $\mathrm{U}$ & $8.73 E-01$ & $1.30 \mathrm{E}+01$ \\
\hline PBU11-1 & 11 & 1 & 98809808 & 27-Jul & Cs-137 & 60 & & $6.51 \mathrm{E}+01$ & $3.38 \mathrm{E}+01$ \\
\hline PBU11-1 & 11 & $\mathrm{I}$ & 98809808 & 27-Jul & $\mathrm{K}-40$ & 530 & & $5.30 \mathrm{E}+02$ & $2.54 \mathrm{E}+02$ \\
\hline PBU11-1 & 11 & 1 & 98809808 & 27-Jul & $\mathrm{Pb}-212$ & 100 & & $1.25 \mathrm{E}+03$ & $8.57 \mathrm{E}+01$ \\
\hline PBU11-1 & 11 & 1 & 98809808 & 27-Jul & $\mathrm{Pb}-214$ & 120 & & $8.95 E+02$ & $7.15 E+01$ \\
\hline PBU11-1 & 11 & 1 & 98809808 & 27-Jul & Tl-208 & 50 & & $3.84 \mathrm{E}+02$ & $3.61 E+01$ \\
\hline PBU11-2 & 11 & 2 & 98809809 & 27-Jul & Gross A & 1730 & $U$ & $9.76 E+01$ & $3.89 \mathrm{E}+02$ \\
\hline PBU11-2 & 11 & 2 & 98809809 & 27-Jul & Gross B & 2960 & $\mathrm{U}$ & $2.81 \mathrm{E}+01$ & $8.12 E+02$ \\
\hline PBU11-2 & 11 & 2 & 98809809 & $27-J u l$ & Ac-228 & 140 & & $1.08 \mathrm{E}+03$ & $9.00 \mathrm{E}+01$ \\
\hline
\end{tabular}




\begin{tabular}{|c|c|c|c|c|c|c|c|c|c|}
\hline $\begin{array}{r}\text { Sample } \\
\text { Number }\end{array}$ & $\underset{\text { Trans. }}{\text { ID }}$ & $\begin{array}{l}\text { Depth } \\
\text { Int. }\end{array}$ & $\begin{array}{c}\text { Anal. Lab } \\
\text { ID }\end{array}$ & Date & Analyte & $\mathrm{DL}(\mathrm{pCi} / \mathrm{kg})$ & Qual. & $\begin{array}{l}\text { Activity } \\
\text { (pCi/kg) }\end{array}$ & $\begin{array}{c} \pm 1 \text { Sigma } \\
(\mathrm{pCi} / \mathrm{kg})\end{array}$ \\
\hline PBU11-2 & 11 & 2 & 98809809 & 27-Jul & $\mathrm{Bi}-212$ & 370 & & $9.62 \mathrm{E}+02$ & $1.72 \mathrm{E}+02$ \\
\hline PBU11-2 & 11 & 2 & 98809809 & $27-J u l$ & Bi-214 & 100 & & $7.24 \mathrm{E}+02$ & $5.51 \mathrm{E}+01$ \\
\hline PBU11-2 & 11 & 2 & 98809809 & 27-Jul & Co-60 & 40 & $U$ & $-6.76 \mathrm{E}+00$ & $1.24 \mathrm{E}+01$ \\
\hline PBU11-2 & 11 & 2 & 98809809 & 27-Jul & Cs-137 & 60 & $\mathrm{U}$ & $3.70 \mathrm{E}+00$ & $1.55 \mathrm{E}+01$ \\
\hline PBU11-2 & 11 & 2 & 98809809 & 27-Jul & $\mathrm{K}-40$ & 420 & & $7.41 \mathrm{E}+02$ & $2.46 \mathrm{E}+02$ \\
\hline PBU11-2 & 11 & 2 & 98809809 & $27-\mathrm{Jul}$ & $\mathrm{Pb}-212$ & 90 & & $1.14 \mathrm{E}+03$ & $7.74 \mathrm{E}+01$ \\
\hline PBU11-2 & 11 & 2 & 98809809 & 27-Jul & $\mathrm{Pb}-214$ & 100 & & $8.57 E+02$ & $6.28 \mathrm{E}+01$ \\
\hline PBU11-2 & 11 & 2 & 98809809 & 27-Jul & Tl-208 & 50 & & $3.11 E+02$ & $3.34 \mathrm{E}+01$ \\
\hline PBU11-3 & 11 & 3 & 98809813 & 27-Jul & Gross A & 4150 & & $5.78 \mathrm{E}+03$ & $1.91 \mathrm{E}+03$ \\
\hline PBU11-3 & 11 & 3 & 98809813 & 27-Jul & Gross B & 7110 & $\mathrm{U}$ & $-4.14 \mathrm{E}+02$ & $1.95 \mathrm{E}+03$ \\
\hline PBU11-3 & 11 & 3 & 98809813 & 27-Jul & Ac-228 & 160 & & $1.09 \mathrm{E}+03$ & $6.80 \mathrm{E}+01$ \\
\hline PBU11-3 & 11 & 3 & 98809813 & 27-Jul & $\mathrm{Bi}-214$ & 90 & & $8.32 E+02$ & $5.97 \mathrm{E}+01$ \\
\hline PBU11-3 & 11 & 3 & 98809813 & 27-Jul & Co-60 & 40 & $\mathrm{U}$ & $2.22 \mathrm{E}+01$ & $1.10 \mathrm{E}+01$ \\
\hline PBU11-3 & 11 & 3 & 98809813 & 27-Jul & Cs-137 & 50 & $\mathrm{U}$ & $2.30 \mathrm{E}+00$ & $1.45 \mathrm{E}+01$ \\
\hline PBU11-3 & 11 & 3 & 98809813 & 27-Jul & $\mathrm{K}-40$ & 380 & & $7.51 \mathrm{E}+02$ & $2.73 E+02$ \\
\hline PBU11-3 & 11 & 3 & 98809813 & 27-Jul & $\mathrm{Pb}-212$ & 90 & & $1.11 \mathrm{E}+03$ & $7.46 \mathrm{E}+01$ \\
\hline PBU11-3 & 11 & 3 & 98809813 & 27-Jul & $\mathrm{Pb}-214$ & 100 & & $7.00 \mathrm{E}+02$ & $6.62 E+01$ \\
\hline PBU11-3 & 11 & 3 & 98809813 & 27-Jul & $\mathrm{Tl}-208$ & 50 & & $3.57 \mathrm{E}+02$ & $3.59 \mathrm{E}+01$ \\
\hline PBU13-1 & 13 & 1 & 98809778 & 27-Jul & Gross A & 4510 & $\mathrm{U}$ & $7.78 \mathrm{E}+02$ & $1.16 \mathrm{E}+03$ \\
\hline PBU13-1 & 13 & 1 & 98809778 & 27-Jul & Gross B & 7710 & $\mathrm{U}$ & $3.14 \mathrm{E}+03$ & $2.31 E+03$ \\
\hline PBU13-1 & 13 & 1 & 98809778 & 27-Jul & Ac-228 & 130 & & $9.81 \mathrm{E}+02$ & $8.11 E+01$ \\
\hline PBU13-1 & 13 & 1 & 98809778 & 27-Jul & $\mathrm{Bi}-212$ & 350 & & $6.35 \mathrm{E}+02$ & $2.09 E+02$ \\
\hline PBU13-1 & 13 & 1 & 98809778 & 27-Jul & $\mathrm{Bi}-214$ & 90 & & $6.89 E+02$ & $5.38 \mathrm{E}+01$ \\
\hline PBU13-1 & 13 & 1 & 98809778 & 27-Jul & Co-60 & 50 & U & $5.70 \mathrm{E}+00$ & $1.29 E+01$ \\
\hline PBU13-1 & 13 & 1 & 98809778 & 27-Jul & Cs-137 & 50 & $\mathrm{U}$ & $3.73 E+01$ & $1.73 E+01$ \\
\hline PBU13-1 & 13 & 1 & 98809778 & 27-Jul & $\mathrm{K}-40$ & 470 & & $6.19 E+02$ & $2.36 \mathrm{E}+02$ \\
\hline PBU13-1 & 13 & 1 & 98809778 & 27-Jul & $\mathrm{Pb}-212$ & 90 & & $1.07 \mathrm{E}+03$ & $7.19 E+01$ \\
\hline
\end{tabular}




\begin{tabular}{|c|c|c|c|c|c|c|c|c|c|}
\hline $\begin{array}{c}\text { Sample } \\
\text { Number }\end{array}$ & $\begin{array}{l}\text { Trans. } \\
\text { ID }\end{array}$ & $\begin{array}{l}\text { Depth } \\
\text { Int. }\end{array}$ & $\begin{array}{c}\text { Anal. Lab } \\
\text { ID }\end{array}$ & Date & Analyte & $\mathrm{DL}(\mathrm{pCi} / \mathrm{kg})$ & Qual. & $\begin{array}{l}\text { Activity } \\
\text { (pCi/kg) }\end{array}$ & $\begin{array}{c} \pm 1 \text { Sigma } \\
(\mathrm{pCi} / \mathrm{kg})\end{array}$ \\
\hline PBUI3-I & 13 & 1 & 98809778 & 27-Jul & $\mathrm{Pb}-214$ & 110 & & $7.43 E+02$ & $6.04 \mathrm{E}+01$ \\
\hline PBU13-1 & 13 & 1 & 98809778 & 27-Jul & Tl-208 & 50 & & $3.62 \mathrm{E}+02$ & $3.73 E+01$ \\
\hline PBU13-2 & 13 & 2 & 98809779 & 27-Jul & Gross A & 3980 & & $4.11 \mathrm{E}+03$ & $1.62 \mathrm{E}+03$ \\
\hline PBU13-2 & 13 & 2 & 98809779 & 27-Jul & Gross B & 6820 & $U$ & $9.68 \mathrm{E}+02$ & $1.96 \mathrm{E}+03$ \\
\hline PBU13-2 & 13 & 2 & 98809779 & 27-Jul & Ac-228 & 200 & & $9.73 E+02$ & $7.22 \mathrm{E}+01$ \\
\hline PBU13-2 & 13 & 2 & 98809779 & 27-Jul & $\mathrm{Bi}-214$ & 80 & & $6.41 \mathrm{E}+02$ & $5.32 E+01$ \\
\hline PBU13-2 & 13 & 2 & 98809779 & 27-Jul & Co-60 & 50 & $\mathrm{U}$ & $-2.04 E+00$ & $1.26 \mathrm{E}+01$ \\
\hline PBU13-2 & 13 & 2 & 98809779 & 27-JuI & Cs-137 & 50 & $\mathrm{U}$ & $1.98 \mathrm{E}+01$ & $1.42 \mathrm{E}+01$ \\
\hline PBU13-2 & 13 & 2 & 98809779 & 27-Jul & $\mathrm{K}-40$ & 900 & $\mathrm{U}$ & $2.55 E+02$ & $2.03 \mathrm{E}+02$ \\
\hline PBU13-2 & 13 & 2 & 98809779 & 27-Jul & $\mathrm{Pb}-212$ & 90 & & $9.89 \mathrm{E}+02$ & $6.84 \mathrm{E}+01$ \\
\hline PBU13-2 & 13 & 2 & 98809779 & 27-Jul & $\mathrm{Pb}-214$ & 110 & & $6.76 E+02$ & $5.91 \mathrm{E}+01$ \\
\hline PBU13-2 & 13 & 2 & 98809779 & 27-Jul & $\mathrm{Tl}-208$ & 40 & & $2.92 E+02$ & $2.91 \mathrm{E}+01$ \\
\hline PBU13-3 & 13 & 3 & 98809780 & 27-Jul & Gross A & 4530 & $U$ & $2.38 E+03$ & $1.49 \mathrm{E}+03$ \\
\hline PBU13-3 & 13 & 3 & 98809780 & 27-Jul & Gross B & 7680 & $\mathrm{U}$ & $3.57 \mathrm{E}+03$ & $2.35 \mathrm{E}+03$ \\
\hline PBU13-3 & 13 & 3 & 98809780 & 27-Jul & Ac-228 & 140 & & $1.10 \mathrm{E}+03$ & $8.59 E+01$ \\
\hline PBU13-3 & 13 & 3 & 98809780 & 27-Jul & $\mathrm{Bi}-212$ & 380 & & $6.68 \mathrm{E}+02$ & $2.18 E+02$ \\
\hline PBU13-3 & 13 & 3 & 98809780 & 27-Jul & $\mathrm{Bi}-214$ & 110 & & $7.08 \mathrm{E}+02$ & $6.01 E+01$ \\
\hline PBU13-3 & 13 & 3 & 98809780 & 27-Jul & Co-60 & 40 & $U$ & $-1.68 E+01$ & $1.30 \mathrm{E}+01$ \\
\hline PBU13-3 & 13 & 3 & 98809780 & 27-Jul & Cs- 137 & 60 & $\mathbf{U}$ & $2.76 \mathrm{E}+01$ & $1.62 E+01$ \\
\hline PBU13-3 & 13 & 3 & 98809780 & 27-Jul & $\mathrm{K}-40$ & 470 & & $5.11 \mathrm{E}+02$ & $2.99 E+02$ \\
\hline PBU13-3 & 13 & 3 & 98809780 & 27-Jul & $\mathrm{Pb}-212$ & 100 & & $1.07 \mathrm{E}+03$ & $7.47 \mathrm{E}+01$ \\
\hline PBU13-3 & 13 & 3 & 98809780 & 27-Jul & $\mathrm{Pb}-214$ & 110 & & $7.59 \mathrm{E}+02$ & $6.09 E+01$ \\
\hline PBU13-3 & 13 & 3 & 98809780 & 27-Jul & TI-208 & 50 & & $3.46 \mathrm{E}+02$ & $3.78 \mathrm{E}+01$ \\
\hline PBU15-1 & 15 & 1 & 98809738 & 27-Jul & Gross A & 5490 & & $1.66 \mathrm{E}+04$ & $3.50 \mathrm{E}+03$ \\
\hline PBU15-1 & 15 & 1 & 98809738 & 27-Jul & Gross B & 8150 & & $1.01 E+04$ & $2.89 E+03$ \\
\hline PBU15-1 & 15 & 1 & 98809738 & 27-Jul & Ac-228 & 170 & & $1.89 \mathrm{E}+03$ & $1.20 \mathrm{E}+02$ \\
\hline PBU15-1 & 15 & 1 & 98809738 & 27-Jul & $\mathrm{Bi}-212$ & 420 & & $1.32 \mathrm{E}+03$ & $2.49 \mathrm{E}+02$ \\
\hline
\end{tabular}




\begin{tabular}{|c|c|c|c|c|c|c|c|c|c|}
\hline $\begin{array}{c}\text { Sample } \\
\text { Number }\end{array}$ & $\begin{array}{c}\text { Trans. } \\
\text { ID }\end{array}$ & $\begin{array}{c}\text { Depth } \\
\text { Int. }\end{array}$ & $\begin{array}{c}\text { Anal. Lab } \\
\text { ID }\end{array}$ & Date & Analyte & DL (pCi/kg) & Qual. & $\begin{array}{l}\text { Activity } \\
\text { (pCi/kg) }\end{array}$ & $\begin{array}{c} \pm 1 \text { Sigma } \\
(\mathrm{pCi} / \mathrm{kg})\end{array}$ \\
\hline PBU15-1 & 15 & 1 & 98809738 & 27-Jul & $\mathrm{Bi}-214$ & 130 & & $9.89 \mathrm{E}+02$ & $7.34 \mathrm{E}+01$ \\
\hline PBU15-1 & 15 & 1 & 98809738 & 27-Jul & Co-60 & 60 & $\mathrm{U}$ & $-3.14 \mathrm{E}+00$ & $1.64 \mathrm{E}+01$ \\
\hline PBU15-1 & 15 & 1 & 98809738 & 27-Jul & Cs-137 & 70 & & $7.00 \mathrm{E}+01$ & $2.26 \mathrm{E}+01$ \\
\hline PBU15-1 & 15 & 1 & 98809738 & 27-Jul & $\mathrm{K}-40$ & 560 & & $1.49 \mathrm{E}+03$ & $3.45 \mathrm{E}+02$ \\
\hline PBU15-1 & 15 & 1 & 98809738 & 27-Jul & $\mathrm{Pb}-212$ & 120 & & $1.61 \mathrm{E}+03$ & $9.96 \mathrm{E}+01$ \\
\hline PBU15-1 & 15 & 1 & 98809738 & 27-Jul & $\mathrm{Pb}-214$ & 130 & & $1.04 \mathrm{E}+03$ & $8.03 E+01$ \\
\hline PBU15-1 & 15 & 1 & 98809738 & 27-Jul & Tl-208 & 60 & & $7.08 \mathrm{E}+02$ & $5.41 \mathrm{E}+01$ \\
\hline PBU15-2 & 15 & 2 & 98809741 & 27-Jul & Gross A & 4370 & & $9.38 \mathrm{E}+03$ & $2.15 \mathrm{E}+03$ \\
\hline PBU15-2 & 15 & 2 & 98809741 & 27-Jul & Gross B & 6200 & & $7.08 \mathrm{E}+03$ & $1.77 \mathrm{E}+03$ \\
\hline PBU15-2 & 15 & 2 & 98809741 & $27-J u l$ & Ac-228 & 160 & & $1.81 \mathrm{E}+03$ & $1.16 \mathrm{E}+02$ \\
\hline PBU15-2 & 15 & 2 & 98809741 & 27-Jul & $\mathrm{Bi}-212$ & 440 & & $9.30 \mathrm{E}+02$ & $2.24 \mathrm{E}+02$ \\
\hline PBU15-2 & 15 & 2 & 98809741 & 27-Jul & $\mathrm{Bi}-214$ & 110 & & $9.57 E+02$ & $6.95 \mathrm{E}+01$ \\
\hline PBU15-2 & 15 & 2 & 98809741 & 27-Jul & Co-60 & 50 & $\mathrm{U}$ & $-2.95 E+00$ & $1.47 \mathrm{E}+01$ \\
\hline PBU15-2 & 15 & 2 & 98809741 & 27-Jul & Cs-137 & 60 & U & $-1.81 \mathrm{E}+01$ & $1.81 \mathrm{E}+01$ \\
\hline PBU15-2 & 15 & 2 & 98809741 & 27-Jul & $\mathrm{K}-40$ & 530 & & $1.26 \mathrm{E}+03$ & $3.20 \mathrm{E}+02$ \\
\hline PBU15-2 & 15 & 2 & 98809741 & 27-Jul & $\mathrm{Pb}-212$ & 110 & & $1.59 \mathrm{E}+03$ & $9.76 \mathrm{E}+01$ \\
\hline PBU15-2 & 15 & 2 & 98809741 & 27-Jul & $\mathrm{Pb}-214$ & 120 & & $9.24 \mathrm{E}+02$ & $7.30 \mathrm{E}+01$ \\
\hline PBU15-2 & 15 & 2 & 98809741 & 27-Jul & Tl-208 & 60 & & $6.03 E+02$ & $5.0 .1 E+01$ \\
\hline PBUं15-3 & 15 & 3 & 98809742 & 27-Jul & Gross A & 6340 & & $1.07 \mathrm{E}+04$ & $3.11 E+03$ \\
\hline PBU15-3 & 15 & 3 & 98809742 & 27-Jul & Gross B & 9890 & $\mathrm{U}$ & $3.08 \mathrm{E}+03$ & $2.99 E+03$ \\
\hline PBU15-3 & 15 & 3 & 98809742 & 27-Jul & Ac-228 & 190 & & $1.73 E+03$ & $1.20 \mathrm{E}+02$ \\
\hline PBU15-3 & 15 & 3 & 98809742 & 27-Jul & $\mathrm{Bi}-212$ & 460 & & $1.06 \mathrm{E}+03$ & $2.72 E+02$ \\
\hline PBU15-3 & 15 & 3 & 98809742 & 27-Jul & $\mathrm{Bi}-214$ & 120 & & $8.78 E+02$ & $7.14 \mathrm{E}+01$ \\
\hline PBU15-3 & 15 & 3 & 98809742 & 27-Jul & Co- $60^{\circ}$ & 50 & $U$ & $3.14 \mathrm{E}+00$ & $1.45 \mathrm{E}+01$ \\
\hline PBU15-3 & 15 & 3 & 98809742 & 27-Jul & Cs-137 & 60 & $\mathrm{U}$ & $6.16 \mathrm{E}+00$ & $1.65 E+01$ \\
\hline PBU15-3 & 15 & 3 & 98809742 & 27-Jul & $\mathrm{K}-40$ & 560 & & $1.73 E+03$ & $3.46 \mathrm{E}+02$ \\
\hline PBU15-3 & 15 & 3 & 98809742 & $27-J u l$ & $\mathrm{~Pb}-212$ & 110 & & $1.59 E+03$ & $9.50 \mathrm{E}+01$ \\
\hline
\end{tabular}




\begin{tabular}{|c|c|c|c|c|c|c|c|c|c|}
\hline $\begin{array}{c}\text { Sample } \\
\text { Number }\end{array}$ & $\begin{array}{c}\text { Trans. } \\
\text { I }\end{array}$ & $\begin{array}{c}\text { Depth } \\
\text { Int. }\end{array}$ & $\begin{array}{c}\text { Anal. Lab } \\
\text { ID }\end{array}$ & Date & Analyte & DL (pCi/kg) & Qual. & $\begin{array}{c}\text { Activity } \\
\text { (pCi/kg) }\end{array}$ & $\begin{array}{c} \pm 1 \text { Sigma } \\
\text { (pCi/kg) }\end{array}$ \\
\hline PBU15-3 & 15 & 3 & 98809742 & $27-J u l$ & Pb-214 & 130 & & $7.97 \mathrm{E}+02$ & $6.91 \mathrm{E}+01$ \\
\hline PBU15-3 & 15 & 3 & 98809742 & $27-J u l$ & Tl-208 & 60 & & $6.11 \mathrm{E}+02$ & $5.04 \mathrm{E}+01$ \\
\hline
\end{tabular}


Downstream

\begin{tabular}{|c|c|c|c|c|c|c|c|c|c|}
\hline $\begin{array}{r}\text { Sample } \\
\text { Number }\end{array}$ & $\begin{array}{c}\text { Trans. } \\
\text { ID }\end{array}$ & $\begin{array}{l}\text { Depth } \\
\text { Int. }\end{array}$ & $\begin{array}{l}\text { Anal. Lab } \\
\text { ID }\end{array}$ & Date & Analyte & $\mathrm{DL}(\mathrm{pCi} / \mathrm{kg})$ & Qual. & $\begin{array}{l}\text { Activity } \\
\text { (pCi/kg) }\end{array}$ & $\begin{array}{c} \pm 1 \text { Sigma } \\
(\mathrm{pCi} / \mathrm{kg})\end{array}$ \\
\hline PBW 1-1 & 1 & 1 & 98809862 & 29-Jul & Gross A & 1350 & U & $1.27 \mathrm{E}+03$ & $5.57 \mathrm{E}+02$ \\
\hline PBW1-1 & 1 & 1 & 98809862 & $29-\mathrm{Jul}$ & Gross B & 2380 & $\mathrm{U}$ & $-8.95 E+01$ & $6.66 \mathrm{E}+02$ \\
\hline PBW1-1 & 1 & 1 & 98809862 & 29-Jul & $B i-214$ & 70 & & $2.49 E+02$ & $3.26 \mathrm{E}+01$ \\
\hline PBW 1-1 & 1 & 1 & 98809862 & 29-Jul & Co-60 & 40 & $\mathrm{U}$ & $8.59 \mathrm{E}+00$ & $8.80 \mathrm{E}+00$ \\
\hline PBW1-1 & 1 & 1 & 98809862 & 29-Jul & Cs-137 & 40 & $\mathrm{U}$ & $1.64 \mathrm{E}+01$ & $1.06 \mathrm{E}+01$ \\
\hline PBW 1-1 & 1 & 1 & 98809862 & 29-Jul & $\mathrm{K}-40$ & 640 & U & $-3.30 \mathrm{E}+02$ & $1.50 \mathrm{E}+02$ \\
\hline PBW1-1 & 1 & 1 & 98809862 & 29-Jul & $\mathrm{Pb}-212$ & 90 & & $3.05 E+02$ & $3.66 \mathrm{E}+01$ \\
\hline PBW1-1 & 1 & 1 & 98809862 & 29-Jul & $\mathrm{Pb}-214$ & 90 & & $2.52 \mathrm{E}+02$ & $3.77 \mathrm{E}+01$ \\
\hline PBW1-1 & 1 & 1 & 98809862 & 29-Jul & Tl-208 & 40 & & $8.89 \mathrm{E}+01$ & $2.07 \mathrm{E}+01$ \\
\hline PBW1-2 & 1 & 2 & 98809863 & 29-Jul & Gross A & 1450 & U & $2.86 \mathrm{E}+02$ & $3.77 \mathrm{E}+02$ \\
\hline PBW 1-2 & 1 & 2 & 98809863 & 29-Jul & Gross B & 2550 & $\mathrm{U}$ & $-4.38 \mathrm{E}+02$ & $6.76 \mathrm{E}+02$ \\
\hline PBW 1-2 & 1 & 2 & 98809863 & 29-Jul & Ac-228 & 140 & & $5.51 E+02$ & $6.92 \mathrm{E}+01$ \\
\hline PBW 1-2 & 1 & 2 & 98809863 & 29-Jul & $\mathrm{Bi}-212$ & 280 & & $4.08 \mathrm{E}+02$ & $1.39 \mathrm{E}+02$ \\
\hline PBW1-2 & 1 & 2 & 98809863 & 29-Jul & $\mathrm{Bi}-214$ & 60 & & $4.24 \mathrm{E}+02$ & $4.46 \mathrm{E}+01$ \\
\hline PBW1-2 & 1 & 2 & 98809863 & 29-Jul & Co-60 & 40 & U & $2.32 E+01$ & $9.50 \mathrm{E}+00$ \\
\hline PBW1-2 & 1 & 2 & 98809863 & 29-Jul & Cs-137 & 40 & & $5.38 \mathrm{E}+01$ & $1.09 \mathrm{E}+01$ \\
\hline PBW1-2 & 1 & 2 & 98809863 & 29-Jul & $\mathrm{K}-40$ & 310 & & $3.30 \mathrm{E}+02$ & $1.85 E+02$ \\
\hline PBW1-2 & 1 & 2 & 98809863 & 29-Jul & $\mathrm{Pb}-212$ & 70 & & $5.14 \mathrm{E}+02$ & $4.49 \mathrm{E}+01$ \\
\hline PBW1-2 & 1 & 2 & 98809863 & 29-Jul & $\mathrm{Pb}-214$ & 90 & & $3.59 E+02$ & $4.92 \mathrm{E}+01$ \\
\hline PBW1-2 & 1 & 2 & 98809863 & 29-Jul & Tl-208 & 40 & & $1.56 \mathrm{E}+02$ & $2.45 E+01$ \\
\hline PBW2-1 & 2 & 1 & 98809864 & 29-Jul & Gross A & 1340 & & $2.63 E+03$ & $7.28 \mathrm{E}+02$ \\
\hline PBW2-1 & 2 & 1 & 98809864 & 29-Jul & Gross B & 2340 & $\mathrm{U}$ & $1.01 \mathrm{E}+03$ & $7.14 \mathrm{E}+02$ \\
\hline PBW2-1 & 2 & 1 & 98809864 & 29-Jul & Ac-228 & 190 & & $1.35 \mathrm{E}+03$ & $9.84 \mathrm{E}+01$ \\
\hline PBW2-1 & 2 & 1 & 98809864 & 29-Jul & Bi-212 & 420 & & $6.27 E+02$ & $1.42 E+02$ \\
\hline PBW2-1 & 2 & 1 & 98809864 & 29-Jul & $\mathrm{Bi}-214$ & 100 & & $7.92 \mathrm{E}+02$ & $6.24 \mathrm{E}+01$ \\
\hline PBW2-1 & 2 & 1 & 98809864 & 29-Jul & Co-60 & 50 & U & $1.95 \mathrm{E}+01$ & $1.12 \mathrm{E}+01$ \\
\hline
\end{tabular}




\begin{tabular}{|c|c|c|c|c|c|c|c|c|c|}
\hline $\begin{array}{c}\text { Sample } \\
\text { Number }\end{array}$ & $\begin{array}{c}\text { Trans. } \\
\text { ID }\end{array}$ & $\begin{array}{c}\text { Depth } \\
\text { Int. }\end{array}$ & $\begin{array}{c}\text { Anal. Lab } \\
\text { ID }\end{array}$ & Date & Analyte & $\mathrm{DL}(\mathrm{pCi} / \mathrm{kg})$ & Qual. & $\begin{array}{l}\text { Activity } \\
\text { (pCi/kg) }\end{array}$ & $\begin{array}{c} \pm 1 \text { Sigma } \\
(\mathrm{pCi} / \mathrm{kg})\end{array}$ \\
\hline PBW2-1 & 2 & 1 & 98809864 & 29-Jul & Cs-137 & 60 & & $6.76 \mathrm{E}+01$ & $1.89 \mathrm{E}+01$ \\
\hline PBW2-1 & 2 & 1 & 98809864 & 29-Jul & $\mathrm{K}-40$ & 480 & $\mathrm{U}$ & $2.61 E+02$ & $2.09 \mathrm{E}+02$ \\
\hline PBW2-1 & 2 & 1 & 98809864 & 29-Jul & $\mathrm{Pb}-212$ & 100 & & $1.29 \mathrm{E}+03$ & $8.59 \mathrm{E}+01$ \\
\hline PBW2-1 & 2 & 1 & 98809864 & 29-Jul & $\mathrm{Pb}-214$ & 120 & & $8.03 E+02$ & $6.78 \mathrm{E}+01$ \\
\hline PBW2-1 & 2 & 1 & 98809864 & 29-Jul & T1-208 & 50 & & $4.03 E+02$ & $3.86 \mathrm{E}+01$ \\
\hline PBW2-2 & 2 & 2 & 98809856 & 29-Jul & Gross A & 1430 & & $2.61 E+03$ & $7.46 \mathrm{E}+02$ \\
\hline PBW2-2 & 2 & 2 & 98809856 & 29-Jul & Gross B & 2540 & $\mathrm{U}$ & $6.03 E+02$ & $7.46 \mathrm{E}+02$ \\
\hline PBW2-2 & 2 & 2 & 98809856 & 29-Jul & Ac-228 & 170 & & $2.17 \mathrm{E}+03$ & $1.21 \mathrm{E}+02$ \\
\hline PBW2-2 & 2 & 2 & 98809856 & 29-Jul & $B i-212$ & 400 & & $1.15 E+03$ & $2.11 E+02$ \\
\hline PBW2-2 & 2 & 2 & 98809856 & 29-Jul & $\mathrm{Bi}-214$ & 100 & & $1.10 \mathrm{E}+03$ & $6.58 \mathrm{E}+01$ \\
\hline PBW2-2 & 2 & 2 & 98809856 & 29-Jul & Co-60 & 50 & $\mathrm{U}$ & $1.51 \mathrm{E}+01$ & $1.29 \mathrm{E}+01$ \\
\hline PBW2-2 & 2 & 2 & 98809856 & 29-Jul & Cs-137 & 50 & $\mathrm{U}$ & $3.38 \mathrm{E}+01$ & $1.95 \mathrm{E}+01$ \\
\hline PBW2-2 & 2 & 2 & 98809856 & 29-Jul & $\mathrm{K}-40$ & 780 & $\mathrm{U}$ & $-1.57 \mathrm{E}+01$ & $1.78 \mathrm{E}+02$ \\
\hline PBW2-2 & 2 & 2 & 98809856 & 29-Jul & $\mathrm{Pb}-212$ & 100 & & $1.88 \mathrm{E}+03$ & $1.09 E+02$ \\
\hline PBW2-2 & 2 & 2 & 98809856 & 29-Jul & $\mathrm{Pb}-214$ & 120 & & $1.21 E+03$ & $7.76 \mathrm{E}+01$ \\
\hline PBW2-2 & 2 & 2 & 98809856 & 29-Jul & Tl-208 & 60 & & $6.86 \mathrm{E}+02$ & $4.84 \mathrm{E}+01$ \\
\hline PBW3-1 & 3 & 1 & 98809857 & 29-Jul & Gross A & $\cdot 1500$ & $\mathrm{U}$ & $2.84 E+02$ & $2.80 \mathrm{E}+02$ \\
\hline PBW3-1 & 3 & 1 & 98809857 & 29-Jul & Gross B & 2670 & $\mathrm{U}$ & $4.30 \mathrm{E}+02$ & $5.38 E+02$ \\
\hline PBW3-1 & 3 & 1 & 98809857 & 29-Jul & Ac-228 & 110 & & $3.05 \mathrm{E}+02$ & $6.18 \mathrm{E}+01$ \\
\hline PBW3-1 & 3 & 1 & 98809857 & 29-Jul & Bi-214 & 60 & & $1.63 \mathrm{E}+02$ & $3.30 \mathrm{E}+01$ \\
\hline PBW3-1 & 3 & 1 & 98809857 & 29-Jul & Co-60 & 30 & $\mathrm{U}$ & $2.12 \mathrm{E}+01$ & $1.15 \mathrm{E}+01$ \\
\hline PBW3-1 & 3 & 1 & 98809857 & 29-Jul & Cs-137 & 30 & & $3.89 \mathrm{E}+01$ & $1.61 \mathrm{E}+01$ \\
\hline PBW3-1 & 3 & 1 & 98809857 & 29-Jul & $\mathrm{K}-40$ & 640 & $\mathrm{U}$ & $1.18 \mathrm{E}+01$ & $1.84 \mathrm{E}+02$ \\
\hline PBW3-1 & 3 & 1 & 98809857 & 29-Jul & $\mathrm{Pb}-212$ & 70 & & $2.56 \mathrm{E}+02$ & $3.46 \mathrm{E}+01$ \\
\hline PBW3-1 & 3 & 1 & 98809857 & 29-Jul & $\mathrm{Pb}-214$ & 70 & & $2.73 E+02$ & $3.70 \mathrm{E}+01$ \\
\hline PBW3-1 & 3 & 1 & 98809857 & 29-Jul & TI-208 & 30 & & $7.68 \mathrm{E}+01$ & $2.54 \mathrm{E}+01$ \\
\hline PBW3-2 & 3 & 2 & 98809858 & 29-Jul & Gross A & 470 & & $4.15 E+02$ & $4.02 E+02$ \\
\hline
\end{tabular}




\begin{tabular}{|c|c|c|c|c|c|c|c|c|c|}
\hline $\begin{array}{c}\text { Sample } \\
\text { Number }\end{array}$ & $\begin{array}{c}\text { Trans. } \\
\text { ID }\end{array}$ & $\begin{array}{l}\text { Depth } \\
\text { Int. }\end{array}$ & $\underset{\text { ID }}{\text { Anal. Lab }}$ & Date & Analyte & $\mathrm{DL}(\mathrm{pCi} / \mathrm{kg})$ & Qual. & $\begin{array}{l}\text { Activity } \\
\text { (pCi/kg) }\end{array}$ & $\begin{array}{c} \pm 1 \text { Sigma } \\
(\mathrm{pCi} / \mathrm{kg})\end{array}$ \\
\hline PBW3-2 & 3 & 2 & 98809858 & 29-Jul & Gross B & 2490 & & $1.14 \mathrm{E}+03$ & $7.54 \mathrm{E}+02$ \\
\hline PBW3-2 & 3 & 2 & 98809858 & 29-Jul & Ac-228 & 120 & & $4.73 E+02$ & $4.99 \mathrm{E}+01$ \\
\hline PBW3-2 & 3 & 2 & 98809858 & 29-Jul & $B i-214$ & 80 & & $2.97 \mathrm{E}+02$ & $4.54 \mathrm{E}+01$ \\
\hline PBW3-2 & 3 & 2 & 98809858 & 29-Jül & Co-60 & 30 & $\mathrm{U}$ & $-4.49 \mathrm{E}-01$ & $6.91 E+00$ \\
\hline PBW3-2 & 3 & 2 & 98809858 & 29-Jul & Cs- 137 & 40 & & $7.73 E+01$ & $2.20 \mathrm{E}+01$ \\
\hline PBW3-2 & 3 & 2 & 98809858 & 29-Jul & $\mathrm{K}-40$ & 270 & & $5.59 \mathrm{E}+02$ & $2.09 \mathrm{E}+02$ \\
\hline PBW3-2 & 3 & 2 & 98809858 & 29-Jul & $\mathrm{Pb}-212$ & 90 & & $3.22 \mathrm{E}+02$ & $3.80 \mathrm{E}+01$ \\
\hline PBW3-2 & 3 & 2 & 98809858 & 29-Jul & $\mathrm{Pb}-214$ & 90 & & $2.49 \mathrm{E}+02$ & $3.97 \mathrm{E}+01$ \\
\hline PBW3-2 & 3 & 2 & 98809858 & 29-Jul & $\mathrm{Tl}-208$ & 40 & & $8.54 \mathrm{E}+01$ & $2.58 \mathrm{E}+01$ \\
\hline PBW4-1 & 4 & 1 & 98809853 & 29-Jul & Gross A & 480 & & $2.35 E+03$ & $7.12 \mathrm{E}+02$ \\
\hline PBW4-1 & 4 & 1 & 98809853 & 29-Jul & Gross B & 2510 & & $1.15 E+03$ & $7.75 E+02$ \\
\hline PBW4-1 & 4 & 1 & 98809853 & 29-Jul & Ac-228 & 130 & & $7.11 \mathrm{E}+02$ & $7.84 \mathrm{E}+01$ \\
\hline PBW4-1 & 4 & 1 & 98809853 & 29-Jul & $\mathrm{Bi}-214$ & 90 & & $4.81 \mathrm{E}+02$ & $5.34 \mathrm{E}+01$ \\
\hline PBW4-1 & 4 & 1 & 98809853 & 29-Jul & Co-60 & 50 & $\mathrm{U}$ & $1.82 \mathrm{E}+00$ & $1.19 E+01$ \\
\hline PBW4-1 & 4 & 1 & 98809853 & 29-Jul & Cs-137 & 50 & & $5.22 E+01$ & $2.07 \mathrm{E}+01$ \\
\hline PBW4-1 & 4 & 1 & 98809853 & 29-Jul & $\mathrm{K}-40$ & 370 & & $4.81 E+02$ & $2.15 E+02$ \\
\hline PBW4-1 & 4 & 1 & 98809853 & 29-Jul & $\mathrm{Pb}-212$ & 80 & & $6.30 \mathrm{E}+02$ & $5.68 \mathrm{E}+01$ \\
\hline PBW4-1 & 4 & 1 & 98809853 & 29-Jul & $\mathrm{Pb}-214$ & 100 & & $5.14 \mathrm{E}+02$ & $5.22 \mathrm{E}+01$ \\
\hline PBW4-1 & 4 & 1 & 98809853 & 29-Jul & $\mathrm{Tl}-208$ & 40 & & $1.95 \mathrm{E}+02$ & $3.14 \mathrm{E}+01$ \\
\hline PBW4-2 & 4 & 2 & 98809854 & 29-Jul & Gross A & 440 & & $2.86 \mathrm{E}+03$ & $7.36 \mathrm{E}+02$ \\
\hline PBW4-2 & 4 & 2 & 98809854 & 29-Jul & Gross B & 2310 & & $5.28 \mathrm{E}+02$ & $6.81 E+02$ \\
\hline PBW4-2 & 4 & 2 & 98809854 & 29-Jul & Ac-228 & 170 & & $9.81 E+02$ & $8.49 E+01$ \\
\hline PBW4-2 & 4 & 2 & 98809854 & 29-Jul & $\mathrm{Bi}-212$ & 380 & & $8.92 E+02$ & $2.16 \mathrm{E}+02$ \\
\hline PBW4-2 & 4 & 2 & 98809854 & 29-Jul & $\mathrm{Bi}-214$ & 100 & & $6.65 \mathrm{E}+02$ & $5.24 \mathrm{E}+01$ \\
\hline PBW4-2 & 4 & 2 & 98809854 & 29-Jul & Co-60 & 40 & $\mathrm{U}$ & $2.19 \mathrm{E}+00$ & $1.05 \mathrm{E}+01$ \\
\hline PBW4-2 & 4 & 2 & 98809854 & 29-Jul & Cs-137 & 50 & & $6.19 E+01$ & $2.09 E+01$ \\
\hline PBW4-2 & 4 & 2 & 98809854 & 29-Jul & $\mathrm{K}-40$ & 520 & & $9.73 E+02$ & $2.61 E+02$ \\
\hline
\end{tabular}




\begin{tabular}{|c|c|c|c|c|c|c|c|c|c|}
\hline $\begin{array}{c}\text { Sample } \\
\text { Number }\end{array}$ & $\underset{\text { ID }}{\text { Trans. }}$ & $\begin{array}{l}\text { Depth } \\
\text { Int. }\end{array}$ & $\underset{\text { Anal. Lab }}{\text { ID }}$ & Date & Analyte & $\mathrm{DL}(\mathrm{pCi} / \mathrm{kg})$ & Qual. & $\begin{array}{l}\text { Activity } \\
\text { (pCi/kg) }\end{array}$ & $\begin{array}{c} \pm 1 \text { Sigma } \\
(\mathrm{pCi} / \mathrm{kg})\end{array}$ \\
\hline PBW4-2 & 4 & 2 & 98809854 & 29-Jul & $\mathrm{Pb}-212$ & 100 & & $8.59 \mathrm{E}+02$ & $6.57 E+01$ \\
\hline PBW4-2 & 4 & 2 & 98809854 & 29-Jul & $\mathrm{Pb}-214$. & 120 & & $6.32 E+02$ & $6.18 \mathrm{E}+01$ \\
\hline PBW4-2 & 4 & 2 & 98809854 & 29-Jul & TI-208 & 50 & & $3.70 \mathrm{E}+02$ & $3.84 \mathrm{E}+01$ \\
\hline PBW5-1 & 5 & 1 & 98809855 & 29-Jul & Gross A & 440 & & $1.40 \mathrm{E}+03$ & $3.89 E+02$ \\
\hline PBW5-1 & 5 & 1 & 98809855 & 29-Jul & Gross B & 2320 & & $4.88 \mathrm{E}+02$ & $4.71 E+02$ \\
\hline PBW5-1 & 5 & 1 & 98809855 & 29-Jul & Ac-228 & 150 & & $9.30 \mathrm{E}+0 \dot{2}$ & $6.81 E+01$ \\
\hline PBW5-1 & 5 & 1 & 98809855 & 29-Jul & $\mathrm{Bi}-212$ & 340 & & $7.38 \mathrm{E}+02$ & $1.36 \mathrm{E}+02$ \\
\hline PBW5-1 & 5 & 1 & 98809855 & 29-Jul & $\mathrm{Bi}-214$ & 90 & & $6.43 E+02$ & $5.28 \mathrm{E}+01$ \\
\hline PBW5-1 & 5 & 1 & 98809855 & 29-Jul & Co-60 & 40 & $\mathrm{U}$ & $1.13 E+01$ & $1.08 \mathrm{E}+01$ \\
\hline PBW5-1 & 5 & 1 & 98809855 & 29-Jul & Cs-137 & 50 & & $5.81 E+01$ & $2.07 \mathrm{E}+01$ \\
\hline PBW5-1 & 5 & 1 & 98809855 & 29-Jul & $\mathrm{K}-40$ & 390 & $\mathrm{U}$ & $2.62 E+02$ & $1.81 \mathrm{E}+02$ \\
\hline PBW5-1 & 5 & 1 & 98809855 & 29-Jul & $\mathrm{Pb}-212$ & 90 & & $8.89 \mathrm{E}+02$ & $6.41 E+01$ \\
\hline PBW5-1 & 5 & 1 & 98809855 & 29-Jul & $\mathrm{Pb}-214$ & 100 & & $5.49 \mathrm{E}+02$ & $6.16 \mathrm{E}+01$ \\
\hline PBW5-1 & 5 & 1 & 98809855 & 29-Jul & Tl-208 & 50 & & $3.11 \mathrm{E}+02$ & $3.35 \mathrm{E}+01$ \\
\hline PBW5-2 & 5 & 2 & 98808509 & 29-Jul & Gross A & 1580 & U & $1.32 \mathrm{E}+03$ & $4.36 \mathrm{E}+02$ \\
\hline PBW5-2 & 5 & 2 & 98808509 & 29-Jul & Gross B & 2760 & $\mathrm{U}$ & $8.43 E+02$ & $5.78 \mathrm{E}+02$ \\
\hline PBW5-2 & 5 & 2 & 98808509 & 29-Jul & Ac-228 & 160 & & $7.76 \mathrm{E}+02$ & $8.38 \mathrm{E}+01$ \\
\hline PBW5-2 & 5 & 2 & 98808509 & 29-Jul & $\mathrm{Bi}-214$ & 90 & & $6.16 E+02$ & $5.42 \mathrm{E}+01$ \\
\hline PBW5-2 & 5 & 2 & 98808509 & 29-Jul & Co-60 & 40 & $\mathrm{U}$ & $-1.60 E+00$ & $1.16 \mathrm{E}+01$ \\
\hline PBW5-2 & 5 & 2 & 98808509 & 29-Jul & Cs-137 & 60 & $\mathrm{U}$ & $5.24 \mathrm{E}+01$ & $1.76 \mathrm{E}+01$ \\
\hline PBW5-2 & 5 & 2 & 98808509 & 29-Jul & $\mathrm{K}-40$ & 430 & & $9.57 E+02$ & $2.50 \mathrm{E}+02$ \\
\hline PBW5-2 & 5 & 2 & 98808509 & 29-Jul & $\mathrm{Pb}-212$ & 90 & & $8.30 E+02$ & $6.19 E+01$ \\
\hline PBW5-2 & 5 & 2 & 98808509 & 29-Jul & $\mathrm{Pb}-214$ & 110 & & $6.30 \mathrm{E}+02$ & $5.70 \mathrm{E}+01$ \\
\hline PBW5-2 & 5 & 2 & 98808509 & 29-Jul & T1-208 & 50 & & $3.24 E+02$ & $3.20 \mathrm{E}+01$ \\
\hline
\end{tabular}


Pond B Sediments

\begin{tabular}{|c|c|c|c|c|c|c|c|c|c|}
\hline $\begin{array}{c}\text { Sample } \\
\text { Number }\end{array}$ & $\begin{array}{c}\text { Trans. } \\
\text { ID }\end{array}$ & $\begin{array}{c}\text { Depth } \\
\text { Int. }\end{array}$ & $\begin{array}{c}\text { Anal. Lab } \\
\text { ID }\end{array}$ & Date & Analyte & $\mathrm{DL}(\mathrm{pCi} / \mathrm{kg})$ & Qual. & $\begin{array}{l}\text { Activity } \\
\text { (pCi/kg) }\end{array}$ & $\begin{array}{c} \pm 1 \text { Sigma } \\
(\mathrm{pCi} / \mathrm{kg})\end{array}$ \\
\hline PBS1-1 & 1 & 1 & 98808500 & 29-Jul C & Gross A & 1900 & & $3.41 \mathrm{E}+03$ & $9.53 E+02$ \\
\hline PBS1-1 & 1 & 1 & 98808500 & 29-Jul & Gross B & 3250 & & $1.32 \mathrm{E}+04$ & $1.50 \mathrm{E}+03$ \\
\hline PBS1-1 & 1 & 1 & 98808500 & 29-Jul & Ac-228 & 130 & & $1.17 \mathrm{E}+03$ & $5.59 \mathrm{E}+01$ \\
\hline PBS1-1 & 1 & 1 & 98808500 & 29-Jul I & $\mathrm{Bi}-212$ & 340 & & $7.30 \mathrm{E}+02$ & $9.70 \mathrm{E}+01$ \\
\hline PBS1-1 & 1 & 1 & 98808500 & 29-Jul I & $\mathrm{Bi}-214$ & 130 & & $7.03 \mathrm{E}+02$ & $4.20 \mathrm{E}+01$ \\
\hline PBS1-1 & 1 & 1 & 98808500 & 29-Jul C & Co- 60 & 50 & $\mathrm{U}$ & $4.62 E+01$ & $9.30 \mathrm{E}+00$ \\
\hline PBS1-1 & 1 & 1 & 98808500 & 29-Jul C & Cs-137 & 60. & & $1.65 E+04$ & $5.24 \mathrm{E}+02$ \\
\hline PBS1-1 & 1 & 1 & 98808500 & 29-Jul & $\mathrm{K}-40$ & 370 & & $7.11 \mathrm{E}+02$ & $1.77 \mathrm{E}+02$ \\
\hline PBS1-1 & 1 & 1 & 98808500 & 29-Jul & $\mathrm{Pb}-212$ & 150 & & $1.08 \mathrm{E}+03$ & $5.45 \mathrm{E}+01$ \\
\hline PBS1-1 & 1 & 1 & 98808500 & 29-Jul & $\mathrm{Pb}-214$ & 190 & & $7.16 \mathrm{E}+02$ & $5.39 \mathrm{E}+01$ \\
\hline PBS1-1 & 1 & 1 & 98808500 & 29-Jul & $\mathrm{Tl}-208$ & 70 & & $4.22 \mathrm{E}+02$ & $3.00 \mathrm{E}+01$ \\
\hline PBS1-1B & 1 & 1 & 98808501 & 29-Jul & Gross A & 1940 & & $2.78 \mathrm{E}+03$ & $8.99 \mathrm{E}+02$ \\
\hline PBS1-1B & 1 & 1 & 98808501 & 29-Jul & Gross B & 3260 & & $1.31 E+04$ & $1.51 \mathrm{E}+03$ \\
\hline PBS1-1B & 1 & 1 & 98808501 & 29-Jul & Ac-228 & 150 & & $1.18 \mathrm{E}+03$ & $5.74 \mathrm{E}+01$ \\
\hline PBS1-1B & 1 & 1 & 98808501 & 29-Jul & $\mathrm{Bi}-212$ & 360 & & $8.08 \mathrm{E}+02$ & $1.33 \mathrm{E}+02$ \\
\hline PBS1-1B & 1 & 1 & 98808501 & 29-Jul & $\mathrm{Bi}-214$ & 130 & & $7.43 \mathrm{E}+02$ & $4.27 \mathrm{E}+01$ \\
\hline PBS1-1B & 1 & 1 & 98808501 & 29-Jul & Co-60 & 40 & & $6.57 \mathrm{E}+01$ & $8.32 E+00$ \\
\hline PBS1-1B & 1 & 1 & 98808501 & 29-Jul & Cs-137 & 70 & & $1.39 \mathrm{E} \div 04$ & $4.42 \mathrm{E}+02$ \\
\hline PBS1-1B & 1 & 1 & 98808501 & 29-Jul & $\mathrm{K}-40$ & 340 & & $1.01 E+03$ & $1.54 \mathrm{E}+02$ \\
\hline PBS1-1B & 1 & 1 & 98808501 & 29-Jul & $\mathrm{Pb}-212$ & 150 & & $1.22 E+03$ & $5.92 \mathrm{E}+01$ \\
\hline PBS1-1B & 1 & 1 & 98808501 & 29-Jul & $\mathrm{Pb}-214$ & 180 & & $7.78 \mathrm{E}+02$ & $5.65 \mathrm{E}+01$ \\
\hline PBS1-1B & 1 & 1 & 98808501 & 29-Jul & Tl-208 & 70 & & $4.24 \mathrm{E}+02$ & $3.11 E+01$ \\
\hline PBS2-1 & 2 & 1 & 98808503 & 29-Jul & Gross A & 1850 & $\mathrm{U}$ & $1.60 \mathrm{E}+03$ & $6.97 \mathrm{E}+02$ \\
\hline PBS2-1 & 2 & 1 & 98808503 & 29-Jul & Gross B & 3230 & & $1.87 \mathrm{E}+04$ & $1.68 \mathrm{E}+03$ \\
\hline PBS2-1 & 2 & 1 & 98808503 & 29-Jul & Ac-228 & 160 & & $1.48 \mathrm{E}+03$ & $7.68 \mathrm{E}+01$ \\
\hline PBS2-1 & 2 & 1 & 98808503 & 29-Jul & $\mathrm{Bi}-212$ & 390 & & $8.59 \mathrm{E}+02$ & $1.41 E+02$ \\
\hline
\end{tabular}




\begin{tabular}{|l|c|c|c|c|c|c|c|c|c|}
\hline $\begin{array}{r}\text { Sample } \\
\text { Number }\end{array}$ & $\begin{array}{c}\text { Trans. } \\
\text { ID }\end{array}$ & $\begin{array}{c}\text { Depth } \\
\text { Int. }\end{array}$ & $\begin{array}{c}\text { Anal. Lab } \\
\text { ID }\end{array}$ & Date & Analyte & DL (pCi/kg) & Qual. & $\begin{array}{c}\text { Activity } \\
(\mathbf{p C i} / \mathrm{kg})\end{array}$ & $\begin{array}{c} \pm 1 \text { Sigma } \\
(\mathbf{p C i} / \mathrm{kg})\end{array}$ \\
\hline PBS2-1 & 2 & 1 & 98808503 & $29-\mathrm{Jul}$ & $\mathrm{Bi}-214$ & 170 & & $1.09 \mathrm{E}+03$ & $5.62 \mathrm{E}+01$ \\
\hline PBS2-1 & 2 & 1 & 98808503 & $29-\mathrm{Jul}$ & $\mathrm{Co}-60$ & 50 & $\mathrm{U}$ & $2.43 \mathrm{E}+01$ & $9.51 \mathrm{E}+00$ \\
\hline PBS2-1 & 2 & 1 & 98808503 & $29-\mathrm{Jul}$ & $\mathrm{Cs}-137$ & 80 & & $2.11 \mathrm{E}+04$ & $6.70 \mathrm{E}+02$ \\
\hline PBS2-1 & 2 & 1 & 98808503 & 29-Jul & $\mathrm{K}-40$ & 840 & $\mathrm{U}$ & $1.36 \mathrm{E}+02$ & $1.36 \mathrm{E}+02$ \\
\hline PBS2-1 & 2 & 1 & 98808503 & 29-Jul & Pb-212 & 180 & & $1.33 \mathrm{E}+03$ & $7.05 \mathrm{E}+01$ \\
\hline PBS2-1 & 2 & 1 & 98808503 & 29-Jul & Pb-214 & 240 & & $9.00 \mathrm{E}+02$ & $7.65 \mathrm{E}+01$ \\
\hline PBS2-1 & 2 & 1 & 98808503 & 29-Jul & Tl-208 & 90 & & $5.08 \mathrm{E}+02$ & $4.04 \mathrm{E}+01$ \\
\hline
\end{tabular}




\section{Appendix C:} GEL Analytical Data 


\section{GEL ANALYTICAL DATA}

\section{Summary}

Nine soil samples for WSRC arrived at GEL Charleston, South Carolina on August 11, 1998, for analysis. The samples listed on the chain arrived without any visible signs of tampering.

The temperature of the samples was $15^{\circ} \mathrm{C}$. The samples were stored properly according to $S W-846$ procedures and the GEL Standard Operating Procedures (SOP).

The following samples were received by the laboratory:

WSRC Sample ID $\quad$ GEL Sample Number

PBL3-2C 9808376-01

PBL5-2C 9808376-02

PBL7-1C 9808376-03

PBL9-1C 9808376-04

PBL11-3C 9808376-05

PBU7-1C 9808376̆-06

PBU11-2C 9808376-07

PBW3-1C 9808376-08

PBS2-1C 9808376-09

\section{Data Quality Case Narrative}

GEL maintains acceptance criteria for QC samples through the use of statistical process control (SPC). The SPC limits are used to qualify data usability.

GEL instruments were properly calibrated during analyses.

All samples were analyzed within the required holding time.

No target analytes were detected in the method blank above the required acceptance limit.

All analyte recoveries in the matrix spike were within required acceptance limits.

All analyte recoveries in the laboratory control sample were within the required acceptance limits.

All sample replicate results were within the required acceptance limits.

None of the samples were diluted.

There were no Nonconformance reports associated with this batch of analyses. 


\section{Analytical Data Table Nomenclature}

Laboratory results are presented for each replicate sample collected. For each analyte in the laboratory analyses tables, the following information is presented:

Sample Number: The WSRC Sample Identification Number

Trans. ID: $\quad$ Transect identification number.

Depth Int: $\quad$ Depth interval.

$\begin{array}{ll}1 \text { - First sampling interval } & 0-1 \text { foot } \\ \text { 2 - Second sampling interval } & 2-4 \text { feet } \\ 3 \text { - Third sampling interval } & 4-10 \text { feet }\end{array}$

Analyte: $\quad$ Parameter measured.

DL (pCi/kg): Detection Limit. The definition of Detection Limit used at GEL is: The minimum level of an analyte that can be determined (identified not quantified) with $99 \%$ confidence. The values are normally achieved by preparing and analyzing seven aliquots of laboratory water spiked 1 to 5 times the estimated method detection limit (MDL), taking the standard deviation and multiplying it against the one-tailed $t$-statistic at $99 \%$. This computed value is then verified for reasonableness by repeating the study using the concentration found in the initial study, calculating an F-ratio, and computing the final limit. Sample specific preparation and dilution factors are applied to these limits when the are reported.

The detection limit is the minimum concentration of a substance that can be identified, measured, and reported with $99 \%$ confidence that the analyte concentration is above zero. It answers the question, "Is it present".

The definition of Quantitation Limit used at GEL is: The lowest concentration that can be reliably achieved within specified limits of precision and accuracy during routine laboratory operating conditions. The QL is generally 5 to 10 times the MDL. However, it may be nominally chosen within these guidelines to simplify data reporting. For many analytes the $\mathrm{QL}$ analyte concentration is selected as the lowest non-zero standard in the calibration curve. Sample QL's are highly matrixdependent. Sample specific preparation and dilution factors are applied to these limits when they are reported.

The $\mathrm{QL}$ is always $\geq \mathrm{DL}$.

Qualifier: $\quad$ Letter indicating special conditions associated with the result

If the final concentration in the sample was found to be below the DL, the value reported is flagged with a " $U$ " qualifier.

If the final concentration in the sample was found to be below the QL but above the DL, then the value reported is flagged with a " $\mathrm{J}$ " qualifier.

If the final concentration in the sample was found to be above the QL, no qualifier is listed for the parameter.

Activity (pCi/kg): Measured result of the analysis

1 Sigma (pCi/kg): One standard deviation 
GEL Analytical Data

\begin{tabular}{|c|c|c|c|c|c|c|c|}
\hline $\begin{array}{c}\text { Sample } \\
\text { ID }\end{array}$ & $\underset{\text { Trans. }}{\text { ID }}$ & $\begin{array}{c}\text { Depth } \\
\text { Int. }\end{array}$ & $\begin{array}{c}\text { Anal. Lab } \\
\text { ID }\end{array}$ & $\mathrm{DL}(\mathrm{pCi} / \mathrm{kg})$ & Qualifier & $\begin{array}{l}\text { Activity } \\
\text { (pCi/kg) }\end{array}$ & $\begin{array}{c} \pm 1 \text { Sigma } \\
(\mathrm{pCi} / \mathrm{kg})\end{array}$ \\
\hline PBL3-2C & 3 & 2. & Gross A & $2.90 \mathrm{E}+03$ & & $7.54 \mathrm{E}+03$ & $2.65 E+03$ \\
\hline PBL3-2C & 3 & 2 & Gross B & $4.95 \mathrm{E}+03$ & & $5.97 \mathrm{E}+03$ & $2.66 \mathrm{E}+03$ \\
\hline PBL3-2C & 3 & 2 & Ac-228 & $1.07 \mathrm{E}+02$ & & $1.03 \mathrm{E}+03$ & $2.26 \mathrm{E}+02$ \\
\hline PBL3-2C & 3 & 2 & $\mathrm{Ba}-133$ & $3.76 \mathrm{E}+01$ & $\mathrm{U}$ & $-1.64 \mathrm{E}+01$ & $2.50 \mathrm{E}+01$ \\
\hline PBL3-2C & 3 & 2 & Cf-249 & $3.67 E+01$ & $\mathrm{U}$ & $9.67 \mathrm{E}+00$ & $2.00 \mathrm{E}+01$ \\
\hline PBL3-2C & 3 & 2 & Cf-251 & $1.13 E+02$ & $\mathrm{U}$ & $-6.02 E+01$ & $6.76 \mathrm{E}+01$ \\
\hline PBL3-2C & 3 & 2 & $\mathrm{Ce}-141$ & $9.29 E+01$ & $\mathrm{U}$ & $4.94 \mathrm{E}+00$ & $5.26 \mathrm{E}+01$ \\
\hline PBL3-2C & 3 & 2 & Ce-144 & $1.94 \mathrm{E}+02$ & $\mathrm{U}$ & $7.35 \mathrm{E}+01$ & $1.07 E+02$ \\
\hline PBL3-2C & 3 & 2 & Co-57 & $2.27 \mathrm{E}+01$ & $\mathrm{U}$ & $-1.67 \mathrm{E}+01$ & $1.35 \mathrm{E}+01$ \\
\hline PBL3-2C & 3 & 2 & Co-58 & 4.18E+01 & U & $-7.85 E+00$ & $2.35 E+01$ \\
\hline PBL3-2C & 3 & 2 & Co-60 & $2.85 \mathrm{E}+01$ & $\mathrm{U}$ & $-6.64 \mathrm{E}+00$ & $1.66 \mathrm{E}+01$ \\
\hline PBL3-2C & 3 & 2 & Cs-134 & $2.87 \mathrm{E}+01$ & U & $-1.62 E+00$ & $1.90 \mathrm{E}+01$ \\
\hline PBL3-2C & 3 & 2 & Cs-135 & $1.36 \mathrm{E}+02$ & $\mathrm{U}$ & $4.89 E+01$ & $8.12 \mathrm{E}+01$ \\
\hline PBL3-2C & 3 & 2 & Cs-137 & $3.57 \mathrm{E}+01$ & $\mathrm{U}$ & $2.60 \mathrm{E}+01$ & $2.10 \mathrm{E}+01$ \\
\hline PBL3-2C & 3 & 2 & Eu-152 & $7.95 \mathrm{E}+01$ & $\mathrm{U}$ & $-2.19 \mathrm{E}+01$ & $4.51 \mathrm{E}+01$ \\
\hline PBL3-2C & 3 & 2 & Eu-154 & $9.38 \mathrm{E}+01$ & $\mathrm{U}$ & $8.18 \mathrm{E}+01$ & $1.33 \mathrm{E}+02$ \\
\hline PBL3-2C & 3 & 2 & Eu-155 & $9.19 \mathrm{E}+01$ & $\mathrm{U}$ & $6.38 \mathrm{E}+01$ & $6.05 \mathrm{E}+01$ \\
\hline PBL3-2C & 3 & 2 & $\mathrm{~K}-40$ & $2.51 \mathrm{E}+02$ & & $1.12 \mathrm{E}+03$ & $3.84 \mathrm{E}+02$ \\
\hline PBL3-2C & 3 & 2 & $\mathrm{Mn}-54$ & $3.58 \mathrm{E}+01$ & $\mathrm{U}$ & $1.46 \mathrm{E}+01$ & $1.88 \mathrm{E}+01$ \\
\hline PBL3-2C & 3 & 2 & $\mathrm{Na}-22$ & $3.21 E+01$ & $\mathrm{U}$ & $2.96 \mathrm{E}+01$ & $4.83 E+01$ \\
\hline PBL3-2C & 3 & 2 & $\mathrm{Nb}-94$ & $2.78 \mathrm{E}+01$ & $\mathrm{U}$ & $-8.61 E+00$ & $1.58 \mathrm{E}+01$ \\
\hline PBL3-2C & 3 & 2 & $\mathrm{~Np}-239$ & $1.66 \mathrm{E}+02$ & $\mathrm{U}$ & $-1.08 \mathrm{E}+01$ & $9.32 \mathrm{E}+01$ \\
\hline PBL3-2C & 3 & 2 & $\mathrm{~Pb}-212$ & $4.92 E+01$ & & $1.14 \mathrm{E}+03$ & $1.41 E+02$ \\
\hline PBL3-2C & 3 & 2 & Pm-144 & $3.21 \mathrm{E}+01$ & $\mathrm{U}$ & $1.13 E+01$ & $1.68 \mathrm{E}+01$ \\
\hline PBL3-2C & 3 & 2 & Pm-146 & $3.97 \mathrm{E}+01$ & $\mathrm{U}$ & $6.33 E+00$ & $2.19 E+01$ \\
\hline PBL3-2C & 3 & 2 & $\mathrm{Ru}-103$ & $5.36 \mathrm{E}+01$ & $\mathrm{U}$ & $1.42 \mathrm{E}+01$ & $2.92 \mathrm{E}+01$ \\
\hline PBL3-2C & 3 & 2 & $\mathrm{Ru}-106$ & $2.55 \mathrm{E}+02$ & $\mathrm{U}$ & $-1.07 \mathrm{E}+01$ & $1.45 \mathrm{E}+02$ \\
\hline PBL3-2C & 3 & 2 & Sb-124 & $4.41 \mathrm{E}+01$ & $\mathrm{U}$ & $1.48 \mathrm{E}+01$ & $2.41 \mathrm{E}+01$ \\
\hline PBL3-2C & 3 & 2 & Sb-125 & $7.89 \mathrm{E}+01$ & $\mathrm{U}$ & $-1.91 \mathrm{E}+01$ & $4.52 \mathrm{E}+01$ \\
\hline PBL3-2C & 3 & 2 & Sn-113 & $4.50 \mathrm{E}+01$ & $\mathrm{U}$ & $-1.48 E+01$ & $2.59 \mathrm{E}+01$ \\
\hline PBL3-2C & 3 & 2 & Sn-126 & $3.34 \mathrm{E}+01$ & $\mathrm{U}$ & $2.17 \mathrm{E}+00$ & $1.81 \mathrm{E}+01$ \\
\hline PBL3-2C & 3 & 2 & $\mathrm{Y}-88$ & 4.17E+01 & U & $1.06 \mathrm{E}+00$ & $2.21 \mathrm{E}+01$ \\
\hline PBL3-2C & 3 & 2 & $\mathrm{Zn}-65$ & $5.52 \mathrm{E}+01$ & $\mathrm{U}$ & $-3.17 E+01$ & $4.07 \mathrm{E}+01$ \\
\hline
\end{tabular}




\begin{tabular}{|c|c|c|c|c|c|c|c|}
\hline $\begin{array}{l}\text { Sample } \\
\text { ID }\end{array}$ & $\begin{array}{c}\text { Trans. } \\
\text { ID }\end{array}$ & $\begin{array}{c}\text { Depth } \\
\text { Int. }\end{array}$ & $\underset{\text { Anal. Lab }}{\text { ID }}$ & $\mathrm{DL}(\mathrm{pCi} / \mathrm{kg})$ & Qualifier & $\begin{array}{r}\text { Activity } \\
\text { (pCi/kg) }\end{array}$ & $\begin{array}{c} \pm 1 \text { Sigma } \\
(\mathrm{pCi} / \mathrm{kg})\end{array}$ \\
\hline PBL3-2C & 3 & 2 & Zr-95 & $7.59 E+01$ & $\mathrm{U}$ & $1.63 \mathrm{E}+01$ & $4.55 \mathrm{E}+01$ \\
\hline PBL5-2C & 5 & 2 & Gross A & $2.44 E+03$ & & $5.23 E+03$ & $2.14 \mathrm{E}+03$ \\
\hline PBL5-2C & 5 & 2 & Gross B & $4.88 \mathrm{E}+03$ & $\mathrm{U}$ & $4.39 E+03$ & $2.50 \mathrm{E}+03$ \\
\hline PBL5-2C & 5 & 2 & Ac-228 & $1.11 E+02$ & & $1.03 E+03$ & $2.24 \mathrm{E}+02$ \\
\hline PBL5-2C & 5 & 2 & Ba-133 & $3.64 \mathrm{E}+01$ & $\mathrm{U}$ & $-1.31 E+00$ & $2.38 \mathrm{E}+01$ \\
\hline PBL5-2C & 5 & 2 & Cf-249 & $3.60 \mathrm{E}+01$ & $\mathrm{U}$ & $-3.15 E+00$ & $1.97 \mathrm{E}+01$ \\
\hline PBL5-2C & 5 & 2 & Cf-251 & $1.10 E+02$ & $\mathrm{U}$ & $-4.53 E+01$ & $6.35 \mathrm{E}+01$ \\
\hline PBL5-2C & 5 & 2 & $\mathrm{Ce}-141$ & $8.71 E+01$ & $\mathrm{U}$ & $6.43 \mathrm{E}+01$ & $6.55 \mathrm{E}+01$ \\
\hline PBL5-2C & 5 & 2 & $\mathrm{Ce}-144$ & $1.96 \mathrm{E}+02$ & $\mathrm{U}$ & $4.48 E+01$ & $1.07 \mathrm{E}+02$ \\
\hline PBL5-2C & 5 & 2 & Co-57 & $2.43 \mathrm{E}+01$ & $\mathrm{U}$ & $5.96 \mathrm{E}+00$ & $1.31 \mathrm{E}+01$ \\
\hline PBL5-2C & 5 & 2 & Co-58 & $3.91 \mathrm{E}+01$ & U & $-8.80 \mathrm{E}+00$ & $2.28 \mathrm{E}+01$ \\
\hline PBL5-2C & 5 & 2 & Co-60 & $3.18 \mathrm{E}+01$ & $\mathrm{U}$ & $7.11 \mathrm{E}+00$ & $1.60 \mathrm{E}+01$ \\
\hline PBL5-2C & 5 & 2 & Cs-134 & $3.00 \mathrm{E}+01$ & $\mathrm{U}$ & $-4.23 E+01$ & $2.00 \mathrm{E}+01$ \\
\hline PBL5-2C & 5 & 2 & Cs-135 & $1.36 \mathrm{E}+02$ & $\mathrm{R}$ & $5.00 \mathrm{E}+02$ & $1.72 \mathrm{E}+02$ \\
\hline PBL5-2C & 5 & 2 & Cs-137 & $3.41 \mathrm{E}+01$ & $\mathrm{U}$ & $1.61 \mathrm{E}+01$ & $2.75 \mathrm{E}+01$ \\
\hline PBL5-2C & 5 & 2 & Eu-152 & $8.01 \mathrm{E}+01$ & $\mathrm{U}$ & $-4.44 E+01$ & $4.94 \mathrm{E}+01$ \\
\hline PBL5-2C & 5 & 2 & Eu-154 & $8.48 \mathrm{E}+01$ & $\mathrm{U}$ & $-1.93 E+01$ & $5.61 \mathrm{E}+01$ \\
\hline PBL5-2C & 5 & 2 & Eu-155 & $9.52 \mathrm{E}+01$ & $\mathrm{U}$ & $8.51 \mathrm{E}+01$ & $8.13 E+01$ \\
\hline PBL5-2C & 5 & 2 & $\mathrm{~K}-40$ & $3.04 \mathrm{E}+02$ & & $4.69 \mathrm{E}+02$ & $3.96 \mathrm{E}+02$ \\
\hline PBL5-2C & 5 & 2 & Mn-54 & $3.47 \mathrm{E}+01$ & $\mathrm{U}$ & $2.32 \mathrm{E}+01$ & $1.94 \mathrm{E}+01$ \\
\hline PBL5-2C & 5 & 2 & $\mathrm{Na}-22$ & $3.07 \mathrm{E}+01$ & $\mathrm{U}$ & $-7.05 \mathrm{E}+00$ & $2.03 E+01$ \\
\hline PBL5-2C & 5 & 2 & Nb-94 & $3.30 \mathrm{E}+01$ & $\mathrm{U}$ & $9.65 E+00$ & $1.80 \mathrm{E}+01$ \\
\hline PBL5-2C & 5 & 2 & $\mathrm{~Np}-239$ & $1.51 E+02$ & $\mathrm{U}$ & $-1.38 E+02$ & $8.86 \mathrm{E}+01$ \\
\hline PBL5-2C & 5 & 2 & $\mathrm{~Pb}-212$ & $5.51 \mathrm{E}+01$ & & $1.16 \mathrm{E}+03$ & $1.45 \mathrm{E}+02$ \\
\hline PBL5-2C & 5 & 2 & Pm-144 & $3.06 \mathrm{E}+01$ & $\mathrm{U}$ & $-7.30 \mathrm{E}+00$ & $1.77 \mathrm{E}+01$ \\
\hline PBL5-2C & 5 & 2 & Pm-146 & $3.72 \mathrm{E}+01$ & $\mathrm{U}$ & $-7.70 \mathrm{E}+00$ & $2.08 \mathrm{E}+01$ \\
\hline PBL5-2C & 5 & 2 & Ru-103 & $5.51 \mathrm{E}+01$ & U & $2.71 \mathrm{E}+01$ & $2.86 \mathrm{E}+01$ \\
\hline PBL5-2C & 5 & 2 & Ru-106 & $2.78 \mathrm{E}+02$ & $\mathrm{U}$ & $-3.90 \mathrm{E}+01$ & $1.80 \mathrm{E}+02$ \\
\hline PBL5-2C & 5 & 2 & Sb-124 & $4.41 \mathrm{E}+01$ & $\mathrm{U}$ & $6.48 \mathrm{E}+00$ & $2.40 \mathrm{E}+01$ \\
\hline PBL5-2C & 5 & 2 & Sb-125 & $7.21 \mathrm{E}+01$ & $\mathrm{U}$ & $-1.48 E+01$ & $4.00 \mathrm{E}+01$ \\
\hline PBL5-2C & 5 & 2 & Sn-113 & $4.79 E+01$ & $\mathrm{U}$ & $3.77 E+00$ & $2.58 \mathrm{E}+01$ \\
\hline PBL5-2C & 5 & 2 & Sn-126 & $3.29 \mathrm{E}+01$ & $\mathrm{U}$ & $1.15 \mathrm{E}+01$ & $1.73 \mathrm{E}+01$ \\
\hline PBL5-2C & 5 & 2 & $Y-88$ & $4.70 \mathrm{E}+01$ & $\mathrm{U}$ & $1.64 \mathrm{E}+01$ & $2.28 \mathrm{E}+01$ \\
\hline PBL5-2C & 5 & 2 & $\mathrm{Zn}-65$ & $6.24 \mathrm{E}+01$ & $\mathrm{U}$ & $2.37 \mathrm{E}+00$ & $3.76 \mathrm{E}+01$ \\
\hline PBL5-2C & 5 & 2 & Zr-95 & $8.79 E+01$ & $\mathrm{U}$ & $7.83 E+01$ & $5.41 E+01$ \\
\hline
\end{tabular}




\begin{tabular}{|c|c|c|c|c|c|c|c|}
\hline $\begin{array}{l}\text { Sample } \\
\text { ID }\end{array}$ & $\underset{\text { Trans. }}{\text { ID }}$ & $\begin{array}{l}\text { Depth } \\
\text { Int. }\end{array}$ & $\begin{array}{c}\text { Anal. Lab } \\
\text { ID }\end{array}$ & $\mathrm{DL}(\mathrm{pCi} / \mathrm{kg})$ & Qualifier & $\begin{array}{r}\text { Activity } \\
(\mathrm{pCi} / \mathrm{kg})\end{array}$ & $\begin{array}{c} \pm 1 \text { Sigma } \\
(\mathrm{pCi} / \mathrm{kg})\end{array}$ \\
\hline PBL7-1C & 7 & 1 & Gross A & $2.11 E+03$ & & $3.12 E+03$ & $1.72 \mathrm{E}+03$ \\
\hline PBL7-1C & 7 & 1 & Gross B & $4.57 E+03$ & U & $9.08 E+02$ & $2.05 E+03$ \\
\hline PBL7-1C & 7 & 1 & Ac-228 & $1.02 E+02$ & & $8.53 E+02$ & $2.11 E+02$ \\
\hline PBL7-1C & 7 & 1 & $\mathrm{Ba}-133$ & 3.37E+01 & $\mathrm{U}$ & $-2.24 \mathrm{E}+00$ & $2.20 \mathrm{E}+01$ \\
\hline PBL7-1C & 7 & 1 & Cf- 249 & $3.45 E+01$ & $\mathrm{U}$ & $7.46 \mathrm{E}+00$ & $1.82 \mathrm{E}+01$ \\
\hline PBL7-1C & 7 & 1 & Cf-251 & $1.02 E+02$ & $\mathrm{U}$ & $-4.06 \mathrm{E}+01$ & $5.82 E+01$ \\
\hline PBL7-1C & 7 & 1 & Ce-141 & $8.90 \mathrm{E}+01$ & $\mathrm{U}$ & $2.33 E+01$ & $6.06 \mathrm{E}+01$ \\
\hline PBL7-1C & 7 & 1 & Ce-144 & $1.80 \mathrm{E}+02$ & $\mathrm{U}$ & $-2.23 \mathrm{E}+01$ & $9.87 \mathrm{E}+01$ \\
\hline PBL7-1C & 7 & 1 & Co-57 & $2.18 \mathrm{E}+01$ & $\mathrm{U}$ & $1.04 \mathrm{E}+00$ & $1.18 \mathrm{E}+01$ \\
\hline PBL7-1C & 7 & 1 & Co-58 & $3.69 \mathrm{E}+01$ & $\mathrm{U}$ & $-5.25 E+00$ & $2.11 E+01$ \\
\hline PBL7-1C & 7 & 1 & Co-60 & $3.02 \mathrm{E}+01$ & $\mathrm{U}$ & $1.39 \mathrm{E}+00$ & $1.59 \mathrm{E}+01$ \\
\hline PBL7-1C & 7 & 1 & Cs-134 & $2.77 \mathrm{E}+01$ & $\mathrm{U}$ & $-1.05 E+01$ & $1.85 \mathrm{E}+01$ \\
\hline PBL7-1C & 7 & 1 & Cs- 135 & $1.23 E+02$ & $\mathrm{R}$ & $2.85 \mathrm{E}+02$ & $1.33 E+02$ \\
\hline PBL7-1C & 7 & 1 & Cs-137 & $3.05 \mathrm{E}+01$ & & $1.20 \mathrm{E}+02$ & $3.59 \mathrm{E}+01$ \\
\hline PBL7-1C & 7 & 1 & Eu-152 & $8.01 E+01$ & $U$ & $-1.15 E+00$ & $4.61 E+01$ \\
\hline PBL7-1C & 7 & 1 & Eu-154 & $8.21 \mathrm{E}+01$ & $\mathrm{U}$ & $2.04 \mathrm{E}+01$ & $4.59 \mathrm{E}+01$ \\
\hline PBL7-1C & 7 & 1 & Eu-155 & $8.62 \mathrm{E}+01$ & $\mathrm{U}$ & $5.58 \mathrm{E}+01$ & $8.73 E+01$ \\
\hline PBL7-1C & 7 & 1 & $\mathrm{~K}-40$ & $2.57 \mathrm{E}+02$ & & $9.84 \mathrm{E}+02$ & $3.46 \mathrm{E}+02$ \\
\hline PBL7-1C & 7 & 1 & Mn-54 & $3.28 \mathrm{E}+01$ & $\mathrm{U}$ & $2.71 \mathrm{E}+00$ & $1.83 \mathrm{E}+01$ \\
\hline PBL7-1C & 7 & 1 & Na-22 & $2.97 \mathrm{E}+01$ & $\mathrm{U}$ & $7.19 \mathrm{E}+00$ & $1.66 \mathrm{E}+01$ \\
\hline PBL7-1C & 7 & 1 & $\mathrm{Nb}-94$ & $2.74 \mathrm{E}+01$ & $\mathrm{U}$ & $1.05 \mathrm{E}-01$ & $1.53 \mathrm{E}+01$ \\
\hline PBL7-1C & 7 & 1 & Np-239 & $1.55 \mathrm{E}+02$ & $\mathrm{U}$ & $-1.85 E+01$ & $8.43 E+01$ \\
\hline PBL7-1C & 7 & 1 & $\mathrm{~Pb}-212$ & $4.81 \mathrm{E}+01$ & & $9.10 \mathrm{E}+02$ & $1.18 \mathrm{E}+02$ \\
\hline PBL7-1C & 7 & 1 & Pm-144 & $3.12 \mathrm{E}+01$ & $\mathrm{U}$ & $2.96 \mathrm{E}+00$ & $1.72 \mathrm{E}+01$ \\
\hline PBL7-1C & 7 & 1 & Pm-146 & $3.66 \mathrm{E}+01$ & $\mathrm{U}$ & $3.60 \mathrm{E}+00$ & $1.96 \mathrm{E}+01$ \\
\hline PBL7-1C & 7 & 1 & Ru-103 & $5.00 \mathrm{E}+01$ & $\mathrm{U}$ & $-5.16 \mathrm{E}+00$ & $2.76 \mathrm{E}+01$ \\
\hline PBL7-1C & 7 & 1 & Ru-106 & $2.69 E+02$ & $U$ & $8.68 \mathrm{E}+01$ & $1.42 \mathrm{E}+02$ \\
\hline PBL7-1C & 7 & 1 & Sb-124 & $4.41 \mathrm{E}+01$ & $\mathrm{U}$ & $1.81 \mathrm{E}+01$ & $2.32 \mathrm{E}+01$ \\
\hline PBL7-1C & 7 & 1 & Sb-125 & $7.47 \mathrm{E}+01$ & $\mathrm{U}$ & $-2.03 E+01$ & $4.16 \mathrm{E}+01$ \\
\hline PBL7-1C & 7 & 1 & Sn-113 & $4.36 \mathrm{E}+01$ & $\mathrm{U}$ & $-3.73 E+00$ & $2.37 \mathrm{E}+01$ \\
\hline PBL7-1C & 7 & 1 & Sn-126 & $2.89 \mathrm{E}+01$ & $\mathrm{U}$ & $-1.22 \mathrm{E}+00$ & $1.62 \mathrm{E}+01$ \\
\hline PBL7-1C & 7 & 1 & $\mathrm{Y}-88$ & $3.11 \mathrm{E}+01$ & $\mathrm{U}$ & $6.71 \mathrm{E}-01$ & $1.58 \mathrm{E}+01$ \\
\hline PBL7-1C & 7 & 1 & $\mathrm{Zn}-65$ & $6.52 \mathrm{E}+01$ & $\mathrm{U}$ & $7.37 \mathrm{E}+00$ & $3.87 \mathrm{E}+01$ \\
\hline PBL7-1C & 7 & 1 & $\mathrm{Zr}-95$ & $7.56 \mathrm{E}+01$ & $\mathrm{U}$ & $-6.09 E+00$ & $4.28 \mathrm{E}+01$ \\
\hline PBL9-1C & 9 & 1 & Gross A & $3.73 E+03$ & & $7.94 \mathrm{E}+03$ & $3.05 E+03$ \\
\hline
\end{tabular}




\begin{tabular}{|c|c|c|c|c|c|c|c|}
\hline $\begin{array}{c}\text { Sample } \\
\text { ID }\end{array}$ & $\begin{array}{c}\text { Trans. } \\
\text { ID }\end{array}$ & $\begin{array}{l}\text { Depth } \\
\text { Int. }\end{array}$ & $\begin{array}{c}\text { Anal. Lab } \\
\text { ID }\end{array}$ & $\mathrm{DL}(\mathrm{pCi} / \mathrm{kg})$ & Qualifier & $\begin{array}{r}\text { Activity } \\
\text { (pCi/kg) }\end{array}$ & $\begin{array}{c} \pm 1 \text { Sigma } \\
(\mathrm{pCi} / \mathrm{kg})\end{array}$ \\
\hline PBL9-1C & 9 & 1 & Gross B & $5.58 E+03$ & & $9.77 \mathrm{E}+03$ & $3.19 \mathrm{E}+03$ \\
\hline PBL9-1C & 9 & 1 & Ac-228 & $1.05 E+02$ & & $1.29 E+03$ & $2.43 E+02$ \\
\hline PBL9-1C & 9 & 1 & Ba-133 & $4.04 \mathrm{E}+01$ & $\mathrm{U}$ & $3.46 \mathrm{E}+00$ & $2.64 \mathrm{E}+01$ \\
\hline PBL9-1C & 9 & 1 & Cf-249 & $3.83 E+01$ & $\mathrm{U}$ & $-4.41 E+00$ & $2.13 E+01$ \\
\hline PBL9-1C & 9 & 1 & Cf-251 & $1.20 \mathrm{E}+02$ & $\mathrm{U}$ & $-1.90 E+00$ & $6.77 \mathrm{E}+01$ \\
\hline PBL9-1C & 9 & 1 & Ce-141 & $1.05 E+02$ & $\mathrm{U}$ & $3.24 \mathrm{E}+01$ & $5.79 \mathrm{E}+01$ \\
\hline PBL9-1C & 9 & 1 & Ce-144 & $2.06 \mathrm{E}+02$ & $\mathrm{U}$ & $-1.92 E+00$ & $1.15 E+02$ \\
\hline PBL9-1C & 9 & 1 & Co-57 & $2.65 E+01$ & $\mathrm{U}$ & $4.72 E+00$ & $1.45 \mathrm{E}+01$ \\
\hline PBL9-1C & 9 & 1 & Co-58 & $4.75 E+01$ & $\mathrm{U}$ & $5.80 \mathrm{E}+00$ & $3.03 E+01$ \\
\hline PBL9-1C & 9 & 1 & Co-60 & $3.84 \mathrm{E}+01$ & $\mathrm{U}$ & $3.83 E+00$ & $2.07 \mathrm{E}+01$ \\
\hline PBL9-1C & 9 & 1 & Cs-134 & $3.33 E+01$ & $\mathrm{U}$ & $1.17 \mathrm{E}+01$ & $2.03 E+01$ \\
\hline PBL9-1C & 9 & 1 & Cs-135 & $1.46 \mathrm{E}+02$ & $\mathrm{R}$ & $3.20 \mathrm{E}+02$ & $1.74 \mathrm{E}+02$ \\
\hline PBL9-1C & 9 & 1 & Cs-137 & $3.87 \mathrm{E}+01$ & & $1.10 \mathrm{E}+02$ & $3.79 E+01$ \\
\hline PBL9-1C & 9 & 1 & Eu-152 & $8.86 \mathrm{E}+01$ & $\mathrm{U}$ & $-2.23 E+01$ & $5.33 E+01$ \\
\hline PBL9-1C & 9 & 1 & Eu-154 & $1.11 \mathrm{E}+02$ & $U$ & $2.86 \mathrm{E}+01$ & $5.83 E+01$ \\
\hline PBL9-1C & 9 & 1 & Eu-155 & $1.04 \mathrm{E}+02$ & $\mathrm{U}$ & $9.08 \mathrm{E}+01$ & $9.43 E+01$ \\
\hline PBL9-1C & 9 & 1 & $\mathrm{~K}-40$ & $3.42 E+02$ & & $6.67 \mathrm{E}+03$ & $9.97 \mathrm{E}+02$ \\
\hline PBL9-1C & 9 & 1 & Mn-54 & $4.18 \mathrm{E}+01$ & $\mathrm{U}$ & $3.75 E+00$ & $2.73 E+01$ \\
\hline PBL9-1C & 9 & 1 & $\mathrm{Na}-22$ & $4.03 E+01$ & $\mathrm{U}$ & $1.04 E+01$ & $2.11 E+01$ \\
\hline PBL9-1C & 9 & 1 & $\mathrm{Nb}-94$ & $3.59 \mathrm{E}+01$ & $\mathrm{U}$ & $6.22 E+00$ & $2.01 \mathrm{E}+01$ \\
\hline PBL9-1C & 9 & 1 & $N p-239$ & $1.75 E+02$ & $\mathrm{U}$ & $-4.74 E+01$ & $9.79 E+01$ \\
\hline PBL9-1C & 9 & 1 & $\mathrm{~Pb}-212$ & $5.49 \mathrm{E}+01$ & & $1.41 E+03$ & $1.66 \mathrm{E}+02$ \\
\hline PBL9-1C & 9 & 1 & Pm-144 & $3.63 E+01$ & U & $-3.73 E+00$ & $2.10 \mathrm{E}+01$ \\
\hline PBL9-1C & 9 & 1 & Pm-146 & $4.30 \mathrm{E}+01$ & $\mathrm{U}$ & $8.93 E+00$ & $2.33 \mathrm{E}+01$ \\
\hline PBL9-1C & 9 & 1 & Ru-103 & $6.05 E+01$ & $\mathrm{U}$ & $9.33 \mathrm{E}+00$ & $3.30 \mathrm{E}+01$ \\
\hline PBL9-1C & 9 & 1 & Ru-106 & $3.10 \mathrm{E}+02$ & $\mathrm{U}$ & $5.62 E+01$ & $1.70 \mathrm{E}+02$ \\
\hline PBL9-1C & 9 & 1 & Sb-124 & $5.02 \mathrm{E}+01$ & $\mathrm{U}$ & $-1.67 \mathrm{E}+00$ & $2.84 \mathrm{E}+01$ \\
\hline PBL9-1C & 9 & 1 & Sb-125 & $9.62 \mathrm{E}+01$ & $\mathrm{U}$ & $2.03 E+01$ & $5.22 \mathrm{E}+01$ \\
\hline PBL9-1C & 9 & 1 & Sn-113 & $5.09 \mathrm{E}+01$ & $U$ & $1.38 \mathrm{E}+01$ & $2.73 E+01$ \\
\hline PBL9-1C & 9 & 1 & $\mathrm{Sn}-126$ & 3. $63 \mathrm{E}+01$ & $\mathrm{U}$ & $8.03 E+00$ & $2.26 \mathrm{E}+01$ \\
\hline PBL9-1C & 9 & 1 & Y-88 & $4.95 E+01$ & $\mathrm{U}$ & $1.66 \mathrm{E}-01$ & $2.63 \mathrm{E}+01$ \\
\hline PBL9-1C & 9 & 1 & $\mathrm{Zn}-65$ & $8.49 \mathrm{E}+01$ & $\mathrm{U}$ & $-3.44 E+01$ & $5.86 \mathrm{E}+01$ \\
\hline PBL9-1C & 9 & 1 & $\mathrm{Zr}-95$ & $8.67 \mathrm{E}+01$ & $\mathrm{U}$ & $2.73 E+00$ & $4.91 \mathrm{E}+01$ \\
\hline PBL11-3C & 11 & 3 & Gross A & $3.73 E+03$ & & $4.28 \mathrm{E}+03$ & $2.41 \mathrm{E}+03$ \\
\hline PBLI1-3C & 11 & 3 & Gross B & $5.85 E+03$ & & $7.26 \mathrm{E}+03$ & $3.10 \mathrm{E}+03$ \\
\hline
\end{tabular}




\begin{tabular}{|c|c|c|c|c|c|c|c|}
\hline $\begin{array}{c}\text { Sample } \\
\text { ID }\end{array}$ & $\begin{array}{c}\text { Trans. } \\
\text { ID }\end{array}$ & $\begin{array}{c}\text { Depth } \\
\text { Int. }\end{array}$ & $\begin{array}{c}\text { Anal. Lab } \\
\text { ID }\end{array}$ & $\mathrm{DL}(\mathrm{pCi} / \mathrm{kg})$ & Qualifier & $\begin{array}{l}\text { Activity } \\
\text { (pCi/kg) }\end{array}$ & $\begin{array}{c} \pm 1 \text { Sigma } \\
(\mathrm{pCi} / \mathrm{kg})\end{array}$ \\
\hline PBL11-3C & 11 & 3 & Ac-228 & $8.64 E+01$ & & $8.43 E+02$ & $1.82 E+02$ \\
\hline PBL11-3C & 11 & 3 & $\mathrm{Ba}-133$ & $2.80 \mathrm{E}+01$ & $\mathrm{U}$ & $-7.13 E+00$ & $1.83 E+01$ \\
\hline PBL11-3C & 11 & 3 & Cf-249 & $2.85 \mathrm{E}+01$ & $\mathrm{U}$ & $1.79 \mathrm{E}+01$ & $1.50 \mathrm{E}+01$ \\
\hline PBL11-3C & 11 & 3 & Cf-251 & $9.31 \mathrm{E}+01$ & $\mathrm{U}$ & $1.89 \mathrm{E}+00$ & $5.03 \mathrm{E}+01$ \\
\hline PBL11-3C & 11 & 3 & $\mathrm{Ce}-141$ & $7.78 \mathrm{E}+01$ & $U$ & $2.86 \mathrm{E}+01$ & $5.81 E+01$ \\
\hline PBL11-3C & 11 & 3 & Ce-144 & $1.59 \mathrm{E}+02$ & $\mathrm{U}$ & $2.71 \mathrm{E}+01$ & $8.35 \mathrm{E}+01$ \\
\hline PBL1 1-3C & 11 & 3 & Co- 57 & $1.88 \mathrm{E}+01$ & $\mathrm{U}$ & $-5.69 E+00$ & $1.13 \mathrm{E}+01$ \\
\hline PBL11-3C & 11 & 3 & Co-58 & $2.89 E+01$ & $\mathrm{U}$ & $-1.39 \mathrm{E}+01$ & $1.72 \mathrm{E}+01$ \\
\hline PBL11-3C & 11 & 3 & Co-60 & $2.23 E+01$ & $\mathrm{U}$ & $-1.24 E+01=$ & $1.34 \mathrm{E}+01$ \\
\hline PBL11-3C & 11 & 3 & Cs-134 & $2.18 \mathrm{E}+01$ & $\mathrm{U}$ & $-3.65 E+00$ & $1.37 \mathrm{E}+01$ \\
\hline PBL11-3C & 11 & 3 & Cs-135 & $8.98 \mathrm{E}+01$ & $\mathrm{U}$ & $7.84 \mathrm{E}+01$ & $8.21 E+01$ \\
\hline PBL11-3C & 11 & 3 & Cs-137 & $2.67 E+01$ & & $6.75 \mathrm{E}+01$ & $2.93 E+01$ \\
\hline PBL11-3C & 11 & 3 & Eu-152 & $6.82 E+01$ & $\mathrm{U}$ & $-4.35 \mathrm{E}+00$ & $3.86 \mathrm{E}+01$ \\
\hline PBL11-3C & 11 & 3 & Eu-154 & $7.05 E+01$ & $\mathrm{U}$ & $5.10 \mathrm{E}+00$ & $3.83 \mathrm{E}+01$ \\
\hline PBL11-3C & 11 & 3 & Eu-155 & $8.02 E+01$ & $\mathrm{U}$ & $6.09 E+00$ & $4.62 \mathrm{E}+01$ \\
\hline PBL11-3C & 11 & 3 & $\mathrm{~K}-40$ & $2.79 \mathrm{E}+02$ & & $4.73 E+02$ & $3.46 \mathrm{E}+02$ \\
\hline PBL11-3C & 11 & 3 & Mn-54 & $2.82 \mathrm{E}+01$ & $\mathrm{U}$ & $2.40 \mathrm{E}+01$ & $1.15 E+01$ \\
\hline PBL11-3C & 11 & 3 & $\mathrm{Na}-22$ & $2.55 \mathrm{E}+01$ & $\mathrm{U}$ & $1.65 \mathrm{E}+00$ & $1.39 \mathrm{E}+01$ \\
\hline PBL11-3C & 11 & 3 & $\mathrm{Nb}-94$ & $2.28 \mathrm{E}+01$ & $\mathrm{U}$ & $9.99 \mathrm{E}-01$ & $1.24 \mathrm{E}+01$ \\
\hline PBL11-3C & 11 & 3 & Np-239 & $1.32 \mathrm{E}+02$ & $\mathrm{U}$ & $-2.74 \mathrm{E}+01$ & $7.80 \mathrm{E}+01$ \\
\hline PBL11-3C & 11 & 3 & $\mathrm{~Pb}-212$ & $4.15 E+01$ & & $8.78 \mathrm{E}+02$ & $1.08 \mathrm{E}+02$ \\
\hline PBL11-3C & 11 & 3 & $\mathrm{Pm}-144$ & $2.60 E+01$ & $\mathrm{U}$ & $3.31 E+00$ & $1.40 \mathrm{E}+01$ \\
\hline PBL11-3C & 11 & 3 & Pm-146 & $3.14 \mathrm{E}+01$ & $\mathrm{U}$ & $-7.02 \mathrm{E}-01$ & $1.80 \mathrm{E}+01$ \\
\hline PBL11-3C & 11 & 3 & $\mathrm{Ru}-103$ & 4.32E+01 & $U$ & $1.54 \mathrm{E}-01$ & $2.48 \mathrm{E}+01$ \\
\hline PBL11-3C & 11 & 3 & Ru-106 & $2.35 \mathrm{E}+02$ & $\mathrm{U}$ & $3.80 \mathrm{E}+01$ & $1.24 \mathrm{E}+02$ \\
\hline PBL11-3C & 11 & 3 & Sb-124 & $3.46 \mathrm{E}+01$ & $\mathrm{U}$ & $7.35 \mathrm{E}+00$ & $1.83 E+01$ \\
\hline PBL11-3C & 11 & 3 & Sb-125 & $6.57 \mathrm{E}+01$ & $\mathrm{U}$ & $-4.82 E+00$ & $3.77 \mathrm{E}+01$ \\
\hline PBL11-3C & 11 & 3 & Sn-113 & $3.34 \mathrm{E}+01$ & $\mathrm{U}$ & $-2.16 \mathrm{E}+01$ & $2.04 \mathrm{E}+01$ \\
\hline PBL11-3C & 11 & 3 & Sn-126 & $2.33 \mathrm{E}+01$ & $\mathrm{U}$ & $-3.61 E+00$ & $1.30 \mathrm{E}+01$ \\
\hline PBL11-3C & 11 & 3 & $\mathrm{Y}-88$ & $4.11 \mathrm{E}+01$ & $\mathrm{U}$ & $1.70 \mathrm{E}+01$ & $1.83 \mathrm{E}+01$ \\
\hline PBL11-3C & 11 & 3 & $\mathrm{Zn}-65$ & $5.00 \mathrm{E}+01$ & $\mathrm{U}$ & $7.54 \mathrm{E}+00$ & $2.99 \mathrm{E}+01$ \\
\hline PBL11-3C & 11 & 3 & $\mathrm{Zr}-95$ & $6.25 \mathrm{E}+01$ & $\mathrm{U}$ & $-1.30 \mathrm{E}+01$ & $3.54 \mathrm{E}+01$ \\
\hline PBU7-1C & 7 & 1 & Gross A & $3.25 \mathrm{E}+03$ & & $8.53 E+03$ & $2.86 \mathrm{E}+03$ \\
\hline PBU7-1C & 7 & 1 & Gross B & $4.19 E+03$ & $\mathrm{U}$ & $4.16 \mathrm{E}+03$ & $2.21 \mathrm{E}+03$ \\
\hline PBU7-1C & 7 & 1 & Ac-228 & $1.04 \mathrm{E}+02$ & & $1.10 \mathrm{E}+03$ & $2.22 E+02$ \\
\hline
\end{tabular}




\begin{tabular}{|c|c|c|c|c|c|c|c|}
\hline $\begin{array}{l}\text { Sample } \\
\text { ID }\end{array}$ & $\begin{array}{c}\text { Trans. } \\
\text { ID }\end{array}$ & $\begin{array}{c}\text { Depth } \\
\text { Int. }\end{array}$ & $\begin{array}{c}\text { Anal. Lab } \\
\text { ID }\end{array}$ & $\mathrm{DL}(\mathrm{pCi} / \mathrm{kg})$ & Qualifier & $\begin{array}{r}\text { Activity } \\
(\mathrm{pCi} / \mathrm{kg})\end{array}$ & $\begin{array}{c} \pm 1 \text { Sigma } \\
(\mathrm{pCi} / \mathrm{kg})\end{array}$ \\
\hline PBU7-1C & 7 & 1 & Ba-133 & $3.53 \mathrm{E}+01$ & $\mathrm{U}$ & $-2.08 \mathrm{E}+01$ & $2.16 \mathrm{E}+01$ \\
\hline PBU7-1C & 7 & 1 & Cf-249 & $3.17 \mathrm{E}+01$ & $\mathrm{U}$ & $-4.51 E+00$ & $1.85 \mathrm{E}+01$ \\
\hline PBU7-1C & 7 & 1 & Cf-251 & $9.93 \mathrm{E}+01$ & $\mathrm{U}$ & $1.45 E+01$ & $5.41 \mathrm{E}+01$ \\
\hline PBU7-1C & 7 & 1 & Ce-141 & $8.07 \mathrm{E}+01$ & $\mathrm{U}$ & $1.73 \mathrm{E}+01$ & $5.52 \mathrm{E}+01$ \\
\hline PBU7-1C & 7 & 1 & Ce-144 & $1.69 \mathrm{E}+02$ & $\mathrm{U}$ & $8.33 E+01$ & $9.00 \mathrm{E}+01$ \\
\hline PBU7-1C & 7 & 1 & Co-57 & $1.94 \mathrm{E}+01$ & $\mathrm{U}$ & $4.67 \mathrm{E}+00$ & $1.03 E+01$ \\
\hline PBU7-1C & 7 & 1 & Co-58 & $3.87 \mathrm{E}+01$ & $\mathrm{U}$ & $1.71 \mathrm{E}+01$ & $2.82 \mathrm{E}+01$ \\
\hline PBU7-1C & 7 & 1 & Co-60 & $2.99 \mathrm{E}+01$ & $\mathrm{U}$ & $5.89 \mathrm{E}+00$ & $1.50 \mathrm{E}+01$ \\
\hline PBU7-1C & 7 & 1 & Cs-134 & $2.66 \mathrm{E}+01$ & $\mathrm{U}$ & $-3.46 \mathrm{E}+00$ & $1.69 \mathrm{E}+01$ \\
\hline PBU7-1C & 7 & 1 & Cs-135 & $1.21 \mathrm{E}+02$ & U & $7.90 \mathrm{E}+01$ & $6.85 \mathrm{E}+01$ \\
\hline PBU7-1C & 7 & 1 & Cs-137 & $2.92 \mathrm{E}+01$ & & $1.66 \mathrm{E}+02$ & $5.32 \mathrm{E}+01$ \\
\hline PBU7-1C & 7 & 1 & Eu-152 & $7.76 \mathrm{E}+01$ & $\mathrm{U}$ & $-1.79 \mathrm{E}+01$ & $4.54 \mathrm{E}+01$ \\
\hline PBU7-1C & 7 & 1 & Eu-154 & $9.53 \mathrm{E}+01$ & $\mathrm{U}$ & $4.83 \mathrm{E}+00$ & $5.06 \mathrm{E}+01$ \\
\hline PBU7-1C & 7 & 1 & Eu-155 & $7.21 \mathrm{E}+01$ & $\mathrm{U}$ & $6.46 \mathrm{E}+01$ & $6.49 \mathrm{E}+01$ \\
\hline PBU7-1C & 7 & 1 & $\mathrm{~K}-40$ & $2.66 \mathrm{E}+02$ & & $6.95 E+02$ & $3.17 \mathrm{E}+02$ \\
\hline PBU7-1C & 7 & 1 & $\mathrm{Mn}-54$ & $3.59 E+01$ & $\mathrm{U}$ & $1.32 \mathrm{E}+01$ & $1.91 \mathrm{E}+01$ \\
\hline PBU7-1C & 7 & 1 & $\mathrm{Na}-22$ & $3.46 \mathrm{E}+01$ & $\mathrm{U}$ & $1.80 \mathrm{E}+00$ & $1.84 \mathrm{E}+01$ \\
\hline PBU7-1C & 7 & 1 & Nb-94 & $3.09 \mathrm{E}+01$ & $\mathrm{U}$ & $2.48 \mathrm{E}+01$ & $1.92 \mathrm{E}+01$ \\
\hline PBU7-1C & 7 & 1 & $\mathrm{~Np}-239$ & $1.32 \mathrm{E}+02$ & $\mathrm{U}$ & $1.24 \mathrm{E}+01$ & $7.07 \mathrm{E}+01$ \\
\hline PBU7-1C & 7 & 1 & $\mathrm{~Pb}-212$ & $4.36 \mathrm{E}+01$ & & $1.20 \mathrm{E}+03$ & $1.57 \mathrm{E}+02$ \\
\hline PBU7-1C & 7 & 1 & Pm-144 & $2.77 \mathrm{E}+01$ & $\mathrm{U}$ & $-2.02 \mathrm{E}+00$ & $1.54 \mathrm{E}+01$ \\
\hline PBU7-1C & 7 & 1 & Pm-146 & $3.80 \mathrm{E}+01$ & U & $1.11 \mathrm{E}+01$ & $2.13 E+01$ \\
\hline PBU7-1C & 7 & 1 & Ru-103 & $4.80 \mathrm{E}+01$ & $\mathrm{U}$ & $-1.04 \mathrm{E}+01$ & $2.67 \mathrm{E}+01$ \\
\hline PBU7-1C & 7 & 1 & Ru-106 & $2.86 \mathrm{E}+02$ & $\mathrm{U}$ & $3.47 \mathrm{E}+01$ & $1.54 \mathrm{E}+02$ \\
\hline PBU7-1C & 7 & 1 & Sb-124 & $4.35 \mathrm{E}+01$ & $\mathrm{U}$ & $2.19 \mathrm{E}+01$ & $2.24 \mathrm{E}+01$ \\
\hline PBU7-1C & 7 & 1 & Sb-125 & $7.45 \mathrm{E}+01$ & U & $4.42 \mathrm{E}+00$ & $4.26 \mathrm{E}+01$ \\
\hline PBU7-1C & 7 & 1 & Sn-113 & $4.24 \mathrm{E}+01$ & $\mathrm{U}$ & $-5.02 \mathrm{E}+00$ & $2.47 \mathrm{E}+01$ \\
\hline PBU7-1C & 7 & 1 & Sn-126 & $3.00 \mathrm{E}+01$ & $\mathrm{U}$ & $1.33 \mathrm{E}+01$ & $2.20 \mathrm{E}+01$ \\
\hline PBU7-1C & 7 & 1 & $\mathrm{Y}-88$ & $3.88 \mathrm{E}+01$ & $\mathrm{U}$ & $-1.75 E+01$ & $2.38 \mathrm{E}+01$ \\
\hline PBU7-1C & 7 & 1 & $\mathrm{Zn}-65$ & $7.24 \mathrm{E}+01$ & $\mathrm{U}$ & $-5.83 \mathrm{E}+01$ & $4.78 \mathrm{E}+01$ \\
\hline PBU7-1C & 7 & 1 & $\mathrm{Zr}-95$ & $7.58 \mathrm{E}+01$ & $\mathrm{U}$ & $2.10 \mathrm{E}+01$ & $4.00 \mathrm{E}+01$ \\
\hline PBU11-2C & 11 & 2 & Gross A & $2.66 \mathrm{E}+03$ & & $5.86 \mathrm{E}+03$ & $2.37 \mathrm{E}+03$ \\
\hline PBU11-2C & 11 & 2 & Gross B & $4.49 \mathrm{E}+03$ & & $8.43 E+03$ & $2.66 \mathrm{E}+03$ \\
\hline PBU11-2C & 11 & 2 & Ac-228 & $2.09 \mathrm{E}+02$ & & $8.81 \mathrm{E}+02$ & $3.40 \mathrm{E}+02$ \\
\hline PBU11-2C & 11 & 2 & $\mathrm{Ba}-133$ & $6.96 \mathrm{E}+01$ & $\mathrm{U}$ & $-1.22 \mathrm{E}+01$ & $4.49 E+01$ \\
\hline
\end{tabular}




\begin{tabular}{|c|c|c|c|c|c|c|c|}
\hline $\begin{array}{l}\text { Sample } \\
\text { ID }\end{array}$ & $\begin{array}{c}\text { Trans. } \\
\text { ID }\end{array}$ & $\begin{array}{l}\text { Depth } \\
\text { Int: }\end{array}$ & $\underset{\text { Anal. Lab }}{\text { ID }}$ & DL (pCi/kg) & Qualifier & $\begin{array}{r}\text { Activity } \\
\text { (pCi/kg) }\end{array}$ & $\begin{array}{c} \pm 1 \text { Sigma } \\
(\mathrm{pCi} / \mathrm{kg})\end{array}$ \\
\hline PBU11-2C & 11 & 2 & Cf-249 & $6.83 E+01$ & $\mathrm{U}$ & $2.37 \mathrm{E}+01$ & $3.64 \mathrm{E}+01$ \\
\hline PBU11-2C & 11 & 2 & Cf-251 & $2.08 \mathrm{E}+02$ & $\mathrm{U}$ & $5.15 E+01$ & $1.17 \mathrm{E}+02$ \\
\hline PBU11-2C & 11 & 2 & $\mathrm{Ce}-141$ & $1.75 E+02$ & $\mathrm{U}$ & $-2.60 \mathrm{E}+01$ & $9.98 \mathrm{E}+01$ \\
\hline PBU11-2C & 11 & 2 & Ce-144 & $3.43 E+02$ & U & $-1.47 E+02$ & $1.99 \mathrm{E}+02$ \\
\hline PBU11-2C & 11 & 2 & Co-57 & $4.54 \mathrm{E}+01$ & $\mathrm{U}$ & $1.58 \mathrm{E}+00$ & $2.53 \mathrm{E}+01$ \\
\hline PBU11-2C & 11 & 2 & Co-58 & $7.85 \mathrm{E}+01$ & U & $-4.02 \mathrm{E}+01$ & $4.83 \mathrm{E}+01$ \\
\hline PBU11-2C & 11 & 2 & Co-60 & $6.01 E+01$ & $\mathrm{U}$ & $1.53 E+01$ & $3.43 E+01$ \\
\hline PBU11-2C & 11 & 2 & Cs-134 & $5.58 \mathrm{E}+01$ & U & $-1.64 E+01$ & $3.79 E+01$ \\
\hline PBU11-2C & 11 & 2 & Cs-135 & $2.55 \mathrm{E}+02$ & $\mathrm{U}$ & $1.42 E+01$ & $1.47 \mathrm{E}+02$ \\
\hline PBU11-2C & 11 & 2 & Cs-137 & $6.43 E+01$ & $\mathrm{U}$ & $3.82 E+01$ & $4.43 E+01$ \\
\hline PBU11-2C & 11 & 2 & Eu-152 & $1.69 E+02$ & U & $3.84 E+00$ & $1.06 \mathrm{E}+02$ \\
\hline PBU11-2C & 11 & 2 & Eu-154 & $1.56 \mathrm{E}+02$ & $\mathrm{U}$ & $-3.92 E+01$ & $8.88 \mathrm{E}+01$ \\
\hline PBU11-2C & 11 & 2 & Eu-155 & $1.85 \mathrm{E}+02$ & $\mathrm{U}$ & $1.22 \mathrm{E}+02$ & $9.92 \mathrm{E}+01$ \\
\hline PBU11-2C & 11 & 2 & $\mathrm{~K}-40$ & $6.64 E+02$ & $\mathrm{U}$ & $4.88 E+02$ & $5.77 \mathrm{E}+02$ \\
\hline PBU11-2C & 11 & 2 & Mn-54 & $6.83 E+01$ & $\mathrm{U}$ & $2.03 E+01$ & $3.68 \mathrm{E}+01$ \\
\hline PBU11-2C & 11 & 2 & $\mathrm{Na}-22$ & $5.65 \mathrm{E}+01$ & $\mathrm{U}$ & $-1.40 E+01$ & $3.22 E+01$ \\
\hline PBU11-2C & 11 & 2 & $\mathrm{Nb}-94$ & $6.24 \mathrm{E}+01$ & $\mathrm{U}$ & $-2.95 E+00$ & $3.55 \mathrm{E}+01$ \\
\hline PBU11-2C & 11 & 2 & $\mathrm{~Np}-239$ & $3.10 \mathrm{E}+02$ & $\mathrm{U}$ & $-7.93 \mathrm{E}+00$ & $1.73 E+02$ \\
\hline PBU11-2C & 11 & 2 & $\mathrm{~Pb}-212$ & $8.92 \mathrm{E}+01$ & & $1.04 E+03$ & $1.59 \mathrm{E}+02$ \\
\hline PBU11-2C & 11 & 2 & Pm-144 & $6.55 \mathrm{E}+01$ & $\mathrm{U}$ & $4.96 \mathrm{E}+00$ & $3.66 \mathrm{E}+01$ \\
\hline PBU11-2C & 11 & 2 & Pm-146 & $7.94 E+01$ & $\mathrm{U}$ & $2.55 E+01$ & $4.26 \mathrm{E}+01$ \\
\hline PBU11-2C & 11 & 2 & Ru-103 & $1.06 \mathrm{E}+02$ & $\mathrm{U}$ & $-9.23 E+00$ & $5.92 \mathrm{E}+01$ \\
\hline PBU11-2C & 11 & 2 & $\mathrm{Ru}-106$ & $5.51 E+02$ & $\mathrm{U}$ & $-3.93 E+01$ & $3.11 E+02$ \\
\hline PBU11-2C & 11 & 2 & Sb-124 & $8.60 \mathrm{E}+01$ & $\mathrm{U}$ & $-3.42 \mathrm{E}+01$ & $5.09 E+01$ \\
\hline PBU11-2C & 11 & 2 & Sb-125 & $1.57 \mathrm{E}+02$ & U & $-4.58 E+00$ & $8.73 E+01$ \\
\hline PBU11-2C & 11 & 2 & Sn-113 & $8.10 \mathrm{E}+01$ & U & $-1.78 E+00$ & $4.46 \mathrm{E}+01$ \\
\hline PBU11-2C & 11 & 2 & Sn-126 & $6.02 \mathrm{E}+01$ & $\mathrm{U}$ & $-3.68 \mathrm{E}+01$ & $3.77 \mathrm{E}+01$ \\
\hline PBU11-2C & 11 & 2 & $Y-88$ & $7.02 \mathrm{E}+01$ & $\mathrm{U}$ & $-2.95 E+01$ & $4.32 \mathrm{E}+01$ \\
\hline PBU11-2C & 11 & 2 & $\mathrm{Zn}-65$ & $1.37 \mathrm{E}+02$ & $\mathrm{U}$ & $5.79 \mathrm{E}+01$ & $7.61 \mathrm{E}+01$ \\
\hline PBU11-2C & 11 & 2 & $\mathrm{Zr}-95$ & $1.59 \mathrm{E}+02$ & $\mathrm{U}$ & $-2.02 \mathrm{E}+01$ & $9.16 \mathrm{E}+01$ \\
\hline PBW3-1C & 3 & 1 & Gross A & $1.87 \mathrm{E}+03$ & & $2.49 \mathrm{E}+03$ & $1.47 \mathrm{E}+03$ \\
\hline PBW3-1C & 3 & 1 & Gross B & $3.93 E+03$ & & $4.01 E+03$ & $2.07 E+03$ \\
\hline PBW3-1C & 3 & 1 & Ac- 228 & $7.96 \mathrm{E}+01$ & & $2.50 \mathrm{E}+02$ & $1.35 \mathrm{E}+02$ \\
\hline PBW3-1C & 3 & 1 & $\mathrm{Ba}-133$ & $2.69 \mathrm{E}+01$ & $\mathrm{U}$ & $1.94 \mathrm{E}+00$ & $2.35 \mathrm{E}+01$ \\
\hline PBW3-1C & 3 & 1 & Cf-249 & $2.16 \mathrm{E}+01$ & $\mathrm{U}$ & $6.24 \mathrm{E}+00$ & $2.38 \mathrm{E}+01$ \\
\hline
\end{tabular}




\begin{tabular}{|c|c|c|c|c|c|c|c|}
\hline $\begin{array}{l}\text { Sample } \\
\text { ID }\end{array}$ & $\begin{array}{c}\text { Trans. } \\
\text { ID }\end{array}$ & $\begin{array}{l}\text { Depth } \\
\text { Int. }\end{array}$ & $\begin{array}{c}\text { Anal. Lab } \\
\text { m }\end{array}$ & $\mathrm{DL}(\mathrm{pCi} / \mathrm{kg})$ & Qualifier & $\begin{array}{l}\text { Activity } \\
\text { (pCi/kg) }\end{array}$ & $\begin{array}{c} \pm 1 \text { Sigma } \\
(\mathrm{pCi} / \mathrm{kg})\end{array}$ \\
\hline PBW3-1C & 3 & 1 & Cf-251 & $7.15 \mathrm{E}+01$ & $\mathrm{U}$ & $-1.63 E+01$ & $5.93 \mathrm{E}+01$ \\
\hline PBW3-1C & 3 & 1 & $\mathrm{Ce}-141$ & $5.91 \mathrm{E}+01$ & $\mathrm{U}$ & $2.19 E+01$ & $4.63 E+01$ \\
\hline PBW3-1C & 3 & 1 & $\mathrm{Ce}-144$ & $1.15 \mathrm{E}+02$ & $\mathrm{U}$ & $-2.76 E+01$ & $9.38 \mathrm{E}+01$ \\
\hline PBW3-1C & 3 & 1 & Co- 57 & $1.43 E+01$ & $\mathrm{U}$ & $4.99 \mathrm{E}+00$ & $1.12 \mathrm{E}+01$ \\
\hline PBW3-1C & 3 & 1 & Co-58 & $3.02 E+01$ & $\mathbf{U}$ & $-4.20 E+00$ & $2.28 \mathrm{E}+01$ \\
\hline PBW3-1C & 3 & 1 & Co-60 & $2.83 E+01$ & $\mathrm{U}$ & $1.89 E+01$ & $2.05 \mathrm{E}+01$ \\
\hline PBW3-1C & 3 & 1 & Cs-134 & $2.22 E+01$ & $\mathrm{U}$ & $-2.42 E+00$ & $2.05 E+01$ \\
\hline PBW3-1C & 3 & 1 & Cs-135 & $8.45 \mathrm{E}+01$ & $\mathrm{U}$ & $4.31 E+01$ & $1.07 \mathrm{E}+02$ \\
\hline PBW3-1C & 3 & 1 & Cs-137 & $2.09 \mathrm{E}+01$ & & $1.15 \mathrm{E}+02$ & $3.19 \mathrm{E}+01$ \\
\hline PBW3-1C & 3 & 1 & Eu-152 & $6.20 \mathrm{E}+01$ & $\mathrm{U}$ & $3.29 \mathrm{E}+01$ & $4.61 E+01$ \\
\hline PBW3-1C & 3 & 1 & Eu-154 & $6.75 E+01$ & $\mathrm{U}$ & $-1.34 \mathrm{E}+01$ & $5.19 \mathrm{E}+01$ \\
\hline PBW3-1C & 3 & 1 & Eu-155 & $5.32 \mathrm{E}+01$ & $\mathrm{U}$ & $2.93 \mathrm{E}+01$ & $4.11 \mathrm{E}+01$ \\
\hline PBW3-1C & 3 & 1 & $\mathrm{~K}-40$ & $2.49 E+02$ & $\mathrm{U}$ & $6.82 \mathrm{E}+01$ & $2.67 E+02$ \\
\hline PBW3-1C & 3 & 1 & $\mathrm{Mn}-54$ & $2.61 E+01$ & $\mathrm{U}$ & $1.96 \mathrm{E}+01$ & $1.77 \mathrm{E}+01$ \\
\hline PBW3-1C & 3 & 1 & $\mathrm{Na}-22$ & $2.44 \mathrm{E}+01$ & $\mathrm{U}$ & $-4.92 E+00$ & $1.88 \mathrm{E}+01$ \\
\hline PBW3-1C & 3 & 1 & $\mathrm{Nb}-94$ & $2.33 E+01$ & $\mathrm{U}$ & $1.76 \mathrm{E}-01$ & $1.76 \mathrm{E}+01$ \\
\hline PBW3-1C & 3 & 1 & Np-239 & $9.90 \mathrm{E}+01$ & $\mathrm{U}$ & $2.88 \mathrm{E}+01$ & $7.78 \mathrm{E}+01$ \\
\hline PBW3-1C & 3 & 1 & $\mathrm{~Pb}-212$ & $3.16 \mathrm{E}+01$ & & $3.57 \mathrm{E}+02$ & $6.84 \mathrm{E}+01$ \\
\hline PBW3-1C & 3 & 1 & $\mathrm{Pm}-144$ & $2.49 \mathrm{E}+01$ & $\mathrm{U}$ & $5.84 \mathrm{E}+00$ & $1.83 \mathrm{E}+01$ \\
\hline PBW3-1C & 3 & 1 & $\mathrm{Pm}-146$ & $2.70 \mathrm{E}+01$ & $\mathrm{U}$ & $1.08 \mathrm{E}+01$ & $1.71 \mathrm{E}+01$ \\
\hline PBW3-1C & 3 & 1 & Ru-103 & $3.39 \mathrm{E}+01$ & U & $2.65 E+01$ & $2.93 E+01$ \\
\hline PBW3-1C & 3 & 1 & $\mathrm{Ru}-106$ & $2.33 E+02$ & $\underline{U}$ & $1.16 \mathrm{E}+02$ & $1.74 \mathrm{E}+02$ \\
\hline PBW3-1C & 3 & 1 & Sb-124 & $3.55 \mathrm{E}+01$ & $\mathrm{U}$ & $2.60 \mathrm{E}+01$ & $2.60 \mathrm{E}+01$ \\
\hline PBW3-1C & 3 & 1 & Sb-125 & $5.81 E+01$ & $\mathrm{U}$ & $1.32 \mathrm{E}+01$ & $4.40 \mathrm{E}+01$ \\
\hline PBW3-1C & 3 & 1 & Sn-113 & $3.55 \mathrm{E}+01$ & $\mathrm{U}$ & $2.82 \mathrm{E}+01$ & $2.82 \mathrm{E}+01$ \\
\hline PBW3-1C & 3 & 1 & Sn-126 & $2.26 \mathrm{E}+01$ & $\mathrm{U}$ & $-3.98 \mathrm{E}+00$ & $1.71 \mathrm{E}+01$ \\
\hline PBW3-1C & 3 & 1 & $Y-88$ & $3.94 \mathrm{E}+01$ & $\mathrm{U}$ & $2.06 \mathrm{E}+01$ & $2.74 E+01$ \\
\hline PBW3-1C & 3 & 1 & $\mathrm{Zn}-65$ & $6.30 \mathrm{E}+01$ & $U$ & $4.81 E+01$ & $4.71 E+01$ \\
\hline PBW3-1C & 3 & 1 & $\mathrm{Zr}-95$ & $6.25 E+01$ & $\mathrm{U}$ & $-1.75 E+00$ & $5.41 E+01$ \\
\hline PBS2-1C & 2 & 1 & Gross A & $2.02 E+03$ & & $4.86 \mathrm{E}+03$ & $2.07 \mathrm{E}+03$ \\
\hline PBS2-1C & 2 & 1 & Gross B & $4.44 E+03$ & & $1.66 \mathrm{E}+04$ & $3.16 E+03$ \\
\hline PBS2-1C & 2 & 1 & Ac-228 & $8.25 E+01$ & & $1.57 \mathrm{E}+03$ & $2.79 \mathrm{E}+02$ \\
\hline PBS2-1C & 2 & 1 & Ba-133 & $5.92 \mathrm{E}+01$ & $\mathrm{U}$ & $-1.93 E+00$ & $3.91 E+01$ \\
\hline PBS2-1C & 2 & 1 & Cf-249 & $5.76 \mathrm{E}+01$ & $\mathrm{U}$ & $4.34 \mathrm{E}+01$ & $3.29 \mathrm{E}+01$ \\
\hline PBS2-1C & 2 & 1 & Cf-251 & $1.49 \mathrm{E}+02$ & $\mathrm{U}$ & $9.39 E+01$ & $1.08 \mathrm{E}+02$ \\
\hline
\end{tabular}




\begin{tabular}{|c|c|c|c|c|c|c|c|}
\hline $\begin{array}{l}\text { Sample } \\
\text { ID }\end{array}$ & $\underset{\text { Trans. }}{\text { To }}$ & $\begin{array}{c}\text { Depth } \\
\text { Int. }\end{array}$ & $\begin{array}{c}\text { Anal. Lab } \\
\text { ID }\end{array}$ & $\mathrm{DL}(\mathrm{pCi} / \mathrm{kg})$ & Qualifier & $\begin{array}{r}\text { Activity } \\
\text { (pCi/kg) }\end{array}$ & $\begin{array}{c} \pm 1 \text { Sigma } \\
(\mathrm{pCi} / \mathrm{kg})\end{array}$ \\
\hline PBS2-1C & 2 & 1 & Ce-141 & $1.17 \mathrm{E}+02$ & $\mathrm{U}$ & $7.39 \mathrm{E}+01$ & $7.70 \mathrm{E}+01$ \\
\hline PBS2-1C & 2 & 1 & Ce-144 & $2.41 \mathrm{E}+02$ & $\mathrm{U}$ & $-1.12 E+02$ & $1.41 E+02$ \\
\hline PBS2-1C & 2 & 1 & Co-57 & $2.99 \mathrm{E}+01$ & $\mathrm{U}$ & $-4.26 \mathrm{E}+00$ & $1.70 \mathrm{E}+01$ \\
\hline PBS2-1C & 2 & 1 & Co-58 & $2.89 \mathrm{E}+01$ & $\mathrm{U}$ & $-6.39 E+00$ & $1.71 \mathrm{E}+01$ \\
\hline PBS2-1C & 2 & 1 & Co-60 & $2.47 \mathrm{E}+01$ & $\mathrm{U}$ & $8.13 E+00$ & $1.33 E+01$ \\
\hline PBS2-1C & 2 & 1 & Cs-134 & $3: 49 \mathrm{E}+01$ & $\mathrm{U}$ & $-5.82 \mathrm{E}+00 \ldots$ & $2.33 E+01$ \\
\hline PBS2-1C & 2 & 1 & Cs-135 & $1.98 \mathrm{E}+02$ & $\mathrm{U}$ & $1.22 \mathrm{E}+02$ & $1.76 \mathrm{E}+02$ \\
\hline PBS2-1C & 2 & 1 & Cs-137 & $3.59 \mathrm{E}+01$ & & $1.94 \mathrm{E}+04$ & $2.21 E+03$ \\
\hline PBS2-1C & 2 & 1 & Eu-152 & $1.30 \mathrm{E}+02$ & $\mathrm{U}$ & $-2.65 E+01$ & $7.53 E+01$ \\
\hline PBS2-1C & 2 & 1 & Eu-154 & $6.34 \mathrm{E}+01$ & $\mathrm{U}$ & $-1.86 \mathrm{E}+01$ & $3.77 \mathrm{E}+01$ \\
\hline PBS2-1C & 2 & 1 & Eu-155 & $1.15 E+02$ & $\mathrm{U}$ & $4.86 \mathrm{E}+01$ & $6.32 \mathrm{E}+01$ \\
\hline PBS2-1C & 2 & 1 & $\mathrm{~K}-40$ & $2.20 \mathrm{E}+02$ & & $3.52 \mathrm{E}+02$ & $2.90 \mathrm{E}+02$ \\
\hline PBS2-1C & 2 & 1 & $\mathrm{Mn}-54$ & $2.27 \mathrm{E}+01$ & R & $2.52 \mathrm{E}+01$ & $1.59 \mathrm{E}+01$ \\
\hline PBS2-1C & 2 & 1 & $\mathrm{Na}-22$ & $2.30 \mathrm{E}+01$ & $\mathrm{U}$ & $-6.67 E+00$ & $1.37 \mathrm{E}+01$ \\
\hline PBS2-1C & 2 & 1 & Nb-94 & $2.56 \mathrm{E}+01$ & $\mathrm{U}$ & $1.65 \mathrm{E}+01$ & $1.40 \mathrm{E}+01$ \\
\hline PBS2-1C & 2 & 1 & $\mathrm{~Np}-239$ & $2.13 E+02$ & $\mathrm{U}$ & $1.84 E+02$ & $1.51 E+02$ \\
\hline PBS2-1C & 2 & 1 & $\mathrm{~Pb}-212$ & $7.04 \mathrm{E}+01$ & & $1.53 E+03$ & $1.77 \mathrm{E}+02$ \\
\hline PBS2-1C & 2 & 1 & $\mathrm{Pm}-144$ & $2.42 \mathrm{E}+01$ & $\mathrm{U}$ & $-1.59 E+00$ & $1.39 \mathrm{E}+01$ \\
\hline PBS2-1C & 2 & 1 & $\mathrm{Pm}-146$ & 7.31E+01 & $\mathrm{U}$ & $-3.61 E+00$ & $4.34 \mathrm{E}+01$ \\
\hline PBS2-1C & 2 & 1 & $\mathrm{Ru}-103$ & $8.57 \mathrm{E}+01$ & $\mathrm{U}$ & $1.99 \mathrm{E}+01$ & $4.80 \mathrm{E}+01$ \\
\hline PBS2-1C & 2 & 1 & $\mathrm{Ru}-106$ & $3.46 \mathrm{E}+02$ & $U$ & $1.42 E+02$ & $1.94 \mathrm{E}+02$ \\
\hline PBS2-1C & 2 & 1 & $\mathrm{Sb}-124$ & $5.44 \mathrm{E}+01$ & $\mathrm{U}$ & $5.50 \mathrm{E}+00$ & $3.09 E+01$ \\
\hline PBS2-1C & 2 & 1 & Sb-125 & $1.48 \mathrm{E}+02$ & $\mathrm{U}$ & $6.26 \mathrm{E}+01$ & $8.64 \mathrm{E}+01$ \\
\hline PBS2-1C & 2 & 1 & Sn-113 & $7.17 \mathrm{E}+01$ & $\mathrm{U}$ & $-3.68 E+01$ & $4.27 \mathrm{E}+01$ \\
\hline PBS2-1C & 2 & 1 & Sn-126 & $2.20 \mathrm{E}+01$ & $\mathrm{U}$ & $-1.10 \mathrm{E}+01$ & $1.35 E+01$ \\
\hline PBS2-1C & 2 & 1 & $\mathrm{Y}-88$ & $2.78 \mathrm{E}+01$ & $\mathrm{U}$ & $-1.94 \mathrm{E}-01$ & $1.55 \mathrm{E}+01$ \\
\hline PBS2-1C & 2 & 1 & $\mathrm{Zn}-65$ & $6.38 \mathrm{E}+01$ & $\mathrm{U}$ & $5.38 \mathrm{E}+00$ & $4.19 \mathrm{E}+01$ \\
\hline PBS2-1C & 2 & 1 & Zr-95 & $6.21 E+01$ & $\mathrm{U}$ & $3.50 \mathrm{E}+01$ & $3.38 \mathrm{E}+01$ \\
\hline
\end{tabular}

